\title{
INOVAÇÃO E GESTÃO PÚBLICA EM SAÚDE: UMA ANÁLISE DA PERSPECTIVA LOCAL
}

\section{CRISTINA MARIA MEIRA DE MELO}

Tese de Doutorado apresentada ao Departamento de Saúde Materno-Infantil da Faculdade de Saúde Pública da Universidade de São Paulo para obtenção do grau de Doutor.

Linha de Pesquisa: Saúde Pública, Interdisciplinaridade e Saúde das Famílias

Orientador: Professor Associado OSWALDO YOSHIMI TANAKA

São Paulo 2001 
Se você não espera o inesperado, você não pode encontrá-lo.

Heraclitus, Século 5 A.C.

Em memória do mestre Ulysses Factum, professor de História no Ginásio de Jequié, Bahia, com quem aprendi a aprender.

Para Bice Kalil e Antônio Fernando Dreyer, por tudo e qualquer coisa, muito. 


\section{AGRADECIMENTOS}

Ao professor Oswaldo Tanaka, pela parceria nesses anos, pela amizade construida e, principalmente, pelo aprendizado mútuo do "diferente", "anômalo", "diverso", "transitório", "complexo", "qualitativo', "quantitativo", "metodologicamente anárquico-baiano", "metodologicamente nipóniconormativo-flexivel", metodologicamente sempre divertido e permeado de afeto. É mesmo um prazer nosso encontro.

Às colegas do Departamento de Enfermagem Comunitária da Escola de Enfermagem da Universidade Federal da Bahia, pela oportunidade de me permitir continuar a aprender. Particularmente quero agradecer a Heloniza Costa, Jeane Oliveira, Mari Saho, Maria Aladilce de Souza, Marisa Almeida, Maristela Pina, Mirian Paiva, Noélia Oliveira, Norma Fagundes, Silvia Ferreira e Valda Novaes.

À Pró-reitoria de Pesquisa e Pós-graduação da Universidade Federal da Bahia, pela bolsa PCDIT/CAPES durante o doutorado. O meu reconhecimento pelo privilégio.

Aos conselheiros locais de saúde; aos membros das comunidades locais e usuários dos serviços públicos de saúde; aos trabalhadores da saúde do Distrito Sanitário Barra/Rio Vermelho e aos entrevistados, atores relevantes da pesquisa, registro aqui o meu compromisso de continuar a participar da luta pela saúde como direito de todos e dever do estado e por uma gestāo democrática e criativa.

À professora Heloniza Costa e a senhora Tânia Palma, membros da diretoria executiva do Projeto UNI/Bahia e à Nilmacy Lobo, pelo apoio logístico, material e afetivo para a realização da pesquisa de campo.

À coordenação do Distrito Sanitário Barra/Rio Vermelho, pela autorização para realizar o trabalho de campo.

À professora Mary Jane Spink, e aos participantes do Núcleo de Pesquisa e Pós-graduaçāo em Psicologia Social e Saúde da PUC/SP, pelas liçōes contra o "horror metodológico".

Aos colaboradores diretos: Nilza e Tânia pelo apoio na articulação e realização dos grupos focais com usuários; a ex-aluna e colega Conceição Feitosa e a Bice Kalil pelas anotações dos grupos focais; Pedro Ribeiro, pelas lições de informática para o tratamento dos dados qualitativos que me fizeram "gostar" desse território sem poesia e José Antonio Pedro Ferreira pela revisão do texto. 
Ao Dr. Francesco Ripa di Meana pela oportunidade de "viver" o cotidiano da saúde italiana na ASL de Viterbo e assim conhecer melhor (e aprender a valorizar) o Brasil.

Ao Professor Francesco Longo pela recepção no CERGAS/Centro de Pesquisa em Administração Sanitária da Universidade Bocconi de Milāo, pela agenda rigorosa e de qualidade que me fez aprender tanto e pela amizade renovada.

Aos servidores no Departamento de Saúde Materno-Infantil da Faculdade de Saúde Pública, pela atenção gentil e pelo modo de ser caloroso no frio paulistano.

Às colegas Edith Laurdisen Ribeiro, Sayuri Maeda, Sonia Andrade e Rosenda Aza, por todas as conversas e trocas, pela amizade.

À Bice Kalil (uma amiga inumerável), Stella Barros (uma amiga kármica) e Maria Auxiliadora Córdova Cristófaro (uma amiga que me faz gostar de ser enfermeira) pela leitura, comentários e sugestōes prévias do texto. Beijo-lhes as mãos (e)ternamente agradecida.

À Danuza Melo, Pablo Queiroz e Diva Melo, pelo afeto e pela convivência que me faz compreender todas as possibilidades do cotidiano (algumas esquecidas), na prática.

E a Ana Angélica Barbosa, Ana Luiza Vilasbôas, Adson França, Adinair França, Anunziata Faustini, Benedita Bárbara, Carmen Teixeira, Conchita Dominguez, Cristina Campos, Delvair de Brito Alves, Dulcelina Carmo, Emanoel Braga, Edelita Araújo, Ernesto Veronesi, Helô Costa, Ivan Kalil, Jeane Oliveira, Jenny Araújo, Joana Demarchi, Laura Ricchina, Lilia Gama, Luciano Melo, Márcio Melo, Marcos Luedy, Maria Aladilce de Souza, Maria Auxiliadora Cristófaro, Maria do Carmo Guimarães, Maria Antonieta Lukesi, Marisa Hirata, Mirian Paiva, Nair Fábio, Neusa Azêvedo, Neusa Sader, Norma Fagundes, Pedro Roberto Ivo, Renan Mello, Rita Règo, Rogério Menezes, Sandra Chaves, Sérgio Vilas Boas, Silvio Roberto dos Anjos, Stella Barros, Vera Formigli, Vera Vilas Boas, Zazá Farias. Todos sabem o porquè. 


\section{RESUMO}

Melo CMM de Inovação e Gestão Pública em Saúde: Uma Análise da Perspectiva Local. São Paulo; 2001.[Tese de Doutorado - Faculdade de Saúde Pública da Universidade de São Paulo].

Esta investigação tem como objetivo identificar e analisar inovações na gestão em saúde de uma perspectiva microlocalizada e tomando em consideração um conceito ampliado de inovação, definido pelos próprios atores/gestores. As inovaçōes estudadas foram analisadas como fenômenos não rotineiros e irregulares e consideradas alternativas à condução da gestão formal. Assim, distinguem-se de inovações que buscam maior eficiência - tradicionalmente através da introdução de novas tecnologias pela direção da organização - já que os significados e resultados identificados não se adaptam a padrões pré-estabelecidos e não podem ser analisados apenas como mudança positiva. A investigaçäo procura responder à hipótese preliminar de que atores/gestores da saúde, mesmo em situaçōes adversas, são capazes de criar/identificar inovações na gestão real da saúde. Outras questões serviram para impulsionar o estudo: Se existem inovações, o que estaria envolvido na criação das mesmas? O que as caracterizaria? Em que formas se expressam? Isso levou à definição dos seguintes objetivos especificos: a) Identificar inovaçōes na gestão em saúde num distrito sanitário; b) Interpretar as características e repercussōes das inovaçōes identificadas; c) Analisar fatores locais da organização e da micropolítica institucional que interferem nas inovaçōes $e$, d).Analisar as enunciaçōes avaliativas dos atores locais sobre as inovações identificadas. A opção por localizar o estudo empirico num espaço concreto e microlocalizado - um distrito sanitário - permitiu investigar inovaçōes no tempo mesmo em que estas podiam estar sendo criadas como experiências emergentes. Para tanto, o percurso metodológico apoiou-se numa abordagem qualitativa, através do estudo de caso, e na utilizaçāo de técnicas adaptadas de análise de conteúdo. Como resultados destacam-se: a capacidade dos atores/gestores locais em identificar inovaçōes na gestão, analisá-las e utilizá-las como espaços diferenciados de ação, comunicação e relação; a criação e implementação de inovaçōes na gestão num contexto em que o fator liderança está fora do âmbito institucional/organizacional da saúde, mas fortemente apoiado por atores que dele fazem parte; o papel relevante dos representantes das camadas ditas mais pobres da sociedade que demonstram maior envolvimento e mesmo capacidade de identificar, compreender o significado e utilizar as inovações; a característica peculiar das inovaçōes estudadas, compreendidas como táticas do cotidiano e como redes transversais de informação; a relação das inovações com a existência de fontes e padrōes anômalos do contexto local, principalmente pela caracteristica processual das mesmas, constituindo-se, ao mesmo tempo, num movimento de recusa à inércia.

Descritores: inovação; gestão pública em saúde; metodologia qualitativa. 


\section{SUMMARY}

Meio CMM de. Inovação e Gestão Pública em Saúde: Uma Análise da Perspectiva Local. [Innovation in Public Health Management: An Analysis from a Local Perspective] São Paulo (BR); 2001.[Tese de Doutorado Faculdade de Saúde Pública da Universidade de São Paulo].

The general objective of this study is to identify and to analyze public health management innovations in a local perspective. The innovation concept adopted in this study was defined by the local actors/managers. They were analyzed as an irregular phenomenon and were considered as alternative tactics to improve the local health management. In this way, these innovations are different from traditional ones, generally new technologies introduced with the objective to implement the health organization efficiency. This study preliminary hypothesis is that the local health actors/managers despite the adverse political and administrative conditions are able to create and to identify innovations in the real health management. Others important questions for the study are: What kind of variables is involved with the creative process? What are the characteristics of the innovations? Trying to answer those questions the following specific objectives were defined: a) To identify health management innovations in a local health system; b) To interpret the characteristics and repercussions caused by the innovations; $c$ ) To analyze the local factors in the health organization and micropolitics that interfere with the innovations; d) To evaluate innovations based on the local actors enunciations. As a case study, the fieldwork was developed in a local health system (health district) to identify and to analyze the innovations as an emergent process. The methodological approach was qualitative in a plural theoretical framework. The data were analyzed by content analysis techniques. The most important outcomes are: 1) the local health actors/managers skills to identify, to analyze and to use innovations as a tactics in the management process; it happens even in a context where the leadership is out of the organization; 2) representatives from poor population demonstrate a better understanding and utilization of the innovations among all actors involved in the management process; 3 ) it has been identified that innovations were understood as ordinary life tactics and also as a tool to build an information networks; 4) the identified innovations relationships with the no ordinary sources at the local context becoming mainly a refusal movement against the inertia.

Descriptors: innovation; public health management; qualitative methodology. 


\section{ÍNDICE}

1 GESTÃO PÚBLICA E INOVAÇÃO EM SAÚDE: APRESENTAÇÃO DO PROBLEMA

1.1 Introdução

1.2 A reforma da administração pública e a gestão pública em saúde no Brasil

1.3 Inovação e gestão pública em saúde

1.4 Delimitando o estudo de caso

2 BASES TEORICO-METODOLOGICAS

2.1Trajetória 29

2.1.1 Abordagens

2.1.2 Implicações éticas

2.1.3 Lições aprendidas

2.2 Técnicas utilizadas

2.2.1 Procedimento 1: momento exploratório

2.2.2 Procedimento 2: entrevistas

2.2.3 Procedimento 3: grupos focais

2.2.4 Procedimento 4: observação e diário de campo

2.2.5 Procedimento 5: leitura e análise de documentos oficiais 50

2.3 Desenho da análise

3 O CONTEXTO EXTERNO AO MUNICÍPIO DE SALVADOR

3.1 A reforma do aparelho de estado no Brasil

3.2 A descentralização da saúde no Brasil 
4.1 A descentralização/municipalização da saúde em Salvador: antecedentes

4.2 A descentralização/municipalização da saúde em Salvador: 1997-2000

4.3 Politica e governo local 88

4.4 A descentralização/municipalização da saúde e o Distrito Sanitário Barra/Rio Vermelho

5 INOVAÇĀO E GESTÃO EM SAÚDE: O CASO DO DISTRITO SANITÁRIO BARRARIO VERMELHO, SALVADOR

5.1 Premissas

5.2 O cotidiano no Distrito Sanitário Barra/Rio Vermelho

5.3 A gestão em saúde no Distrito Sanitário Barra/Rio Vermelho

5.3.1 Perfil do gestor institucional

5.3.2 Avaliação da gestão local em saúde

5.4 Definindo inovação

5.4.1 Quais categorias? 129

5.5 Identificando inovações

5.5.1 Inovação: o movimento dos Conselhos Locais de Saúde

5.5.1.1 Papel dos Conselhos Locais de Saúde

5.5.1.2 Perfil dos Conselheiros Locais de Saúde 138

5.5.1.3 Ações e táticas do cotidiano

5.5.1.5 Avaliação dos Conselhos Locais de Saúde 
5.5.2 Inovação: o espaço de atuação do Programa de Agentes

Comunitários de Saúde/PACS

5.5.2.1 Premissas

5.5.2.2 PACS: significado e uso estratégico local $\quad 160$

5.5.2.3 Repercussões 165

$\begin{array}{ll}\text { 5.5.2.4 Avaliação do PACS } & 170\end{array}$

5.5.2.5 Comentários finais $\quad 177$

5.5.3 Inovação: o trabalho em parceria no Projeto UNI/Bahia 178

$\begin{array}{ll}\text { 5.5.3.1 Premissas } & 178\end{array}$

$\begin{array}{ll}\text { 5.5.3.2 A parceria como inovação } & 178\end{array}$

5.5.3.3 Repercussões 183

5.5.3.4 Avaliação do "espaço de parceria" no Projeto UNI/Bahia 190

5.5.3.5 Comentários finais 196

5.5.4 Inovação: o trabalho sobre a violência no Distrito Sanitário Barra/ 197

Rio Vermelho

5.5.4.1 Premissas 197

5.5.4.2 Características $\quad 199$

5.5.4.3 Repercussões $\quad 201$

5.5.4.4 Avaliação do trabalho sobre a violência 208

5.5.4.5 Comentário finais $\quad 215$

6 CONSIDERAÇÕES FINAIS $\quad 216$

7 REFERÊNCIAS 225

ANEXOS

Anexo 1 Guia de perguntas para entrevista Anexo 2 Guia de perguntas para grupo focal Anexo 3 Roteiro para anotação do grupo focal Anexo 4 Quadros preliminares para análise dos achados Anexo 5 Lista preliminar de nós para análise produzidos no Q.S.R. NUD.IST 


\section{LISTA DE FIGURAS}

Figura 1 - Lista final de nós adotada como guia para a análise dos achados

Figura 2 - Árvore de categorias de análise

Figura 3 - Mapa da cidade do Salvador, Bahia, com destaque para

a área correspondente ao Distrito Sanitário Barra/Rio Vermelho

Figura 4 - Identificação de inovações em saúde no DSBRV

segundo a autoria, Salvador, 1999

\section{LISTA DE QUADROS}

Quadro 1 - Relação entre produtos utilizados no trabalho de campo

e atores locais envolvidos

Quadro 2 - Caracteristicas na condução do governo local na saúde,

Salvador, 1999

Quadro 2a - Características na condução do governo local na saúde,

Salvador, 1999

Quadro 2b - Caracteristicas na condução do governo local na saúde.

Salvador, 1999

Quadro 2c - Características na condução do governo local na saúde,

Salvador, 1999

Quadro 3 - O processo de municipalização da saúde numa perspectiva valorativa

Quadro 4 - Impacto da municipalização no DSBRV

Quadro 5 - Impacto da municipalização no gerenciamento do DSBRV

Quadro 6 - Influência da municipalização quanto à disponibilidade de recursos 
Quadro 8 - Perfil dos gestores institucionais no DSBRV, 1999

Quadro 9 - Análise avaliativa da capacidade e autonomia

de gestão no DSBRV, 1999

Quadro 10 - Análise avaliativa do controle social na gestão

do DSBRV, 1999

Quadro 11 - Tema-eixo: Definindo Inovação

Quadro 11a - Tema-eixo: Definindo Inovação

Quadro 11b - Tema-eixo: Definindo Inovação

Quadro 11c - Tema-eixo: Definindo Inovação

Quadro 11d - Tema-eixo: Definindo Inovação

Quadro 12 - Papel dos CLS no DSBRV, 1999

Quadro 13 - Perfil dos Conselheiros Locais de Saúde no DSBRV,

Salvador, 1999

Quadro 14 - Atuação dos Conselhos Locais de Saúde no DSBRV por Membros do Conselho Municipal de Saúde, 1999

Quadro 15 - Atuação dos Conselhos Locais de Saúde no DSBRV

por Conselheiros Locais de Saúde representantes da comunidade, 1999

Quadro 16 - Atuação dos Conselhos Locais de Saúde no DSBRV

por Conselheiros Locais de Saúde representantes dos trabalhadores da saúde, 1999

Quadro 17 - Repercussões funcionais

Quadro 18 - Repercussões sobre a ação dos gestores institucionais

Quadro 19 - Repercussões nos serviços

Quadro 20 - Repercussões na população

Quadro 21 - Repercussões nos conselheiros locais de saúde

Quadro 22 - Análise avaliativa dos CLS por Conselheiros Locais

de Saúde representantes da comunidade, DSBRV, 1999

Quadro 22a - Análise avaliativa dos CLS por Gerentes de Unidades de Saúde, DSBRV, 1999 
Quadro 22b - Análise avaliativa dos CLS por Conselheiros Locais

de Saúde representantes dos trabalhadores da saúde, DSBRV, 1999

Quadro 22c - Análise avaliativa dos CLS por membros do

Conselho Municipal de Saúde, DSBRV, 1999

Quadro 22d - Análise avaliativa dos CLS por Trabalhadores da Saúde,

DSBRV, 1999

Quadro 23 - Espaço de atuação do PACS: significado e uso estratégico

Quadro 24 - Repercussões nos serviços de saúde

Quadro 24a - Repercussões nos trabalhadores da saúde

Quadro 24b - Repercussões na população da área

Quadro 25 - Análise avaliativa do PACS por Conselheiros Locais

de Saúde representantes da comunidade, DSBRV, 1999

Quadro 25a - Análise avaliativa do PACS por membros do

Conselho Municipal de Saúde, DSBRV, 1999

Quadro 25b - Análise avaliativa do PACS por Trabalhadores da Saúde, DSBRV, 1999

Quadro 25c - Análise avaliativa do PACS por Gerentes de Unidades de Saúde, DSBRV, 1999

Quadro 25d - Análise avaliativa do PACS por membros da Coordenação do DSBRV, 1999

Quadro 25e - Análise avaliativa do PACS por Usuários, DSBRV, 1999

Quadro 26 - O Projeto UNI/BA como espaço de desenvolvimento e fortalecimento de parcerias

Quadro 26a - O Projeto UNI/BA como espaço de atuação de grupos com compromisso político com a saúde

Quadro 26b - O Projeto UNI/BA como espaço de articulação e ações

na rede de serviços de saúde

Quadro 27 - Repercussões na gestão do DSBRV

Quadro 27a - Repercussões nas ações e serviços de saúde

Quadro 27b - Repercussões na organização/reorganização dos CLS 
Quadro 28 - Análise avaliativa do "espaço de parceria" no Projeto UNI/BA por Conselheiros Locais de Saúde representantes dos trabalhadores da saúde. DSBRV, 1999

Quadro 28a - Análise avaliativa do "espaço de parceria" no Projeto UNI/BA 192 por Conselheiros Locais de Saúde representantes da comunidade, DSBRV, 1999

Quadro 28b - Análise avaliativa do "espaço de parceria" no Projeto UNI/BA por membros do Conselho Municipal de Saúde, DSBRV, 1999

Quadro 28c - Análise avaliativa do "espaço de parceria" no Projeto UNI/BA por Trabalhadores da Saúde, DSBRV, 1999

Quadro 28d - Análise avaliativa do "espaço de parceria" no Projeto UNI/BA 195 por ex-membro da Coordenação do DSBRV, 1999

Quadro 29 - Repercussões no modo de compreender a realidade e de agir 203

Quadro 29a - Repercussões nas pessoas

Quadro 29b - Repercussões nos serviços de saúde 205

Quadro 29c - Repercussōes nas instituiçōes 207

Quadro 30 - Análise avaliativa do trabalho sobre a violência por 209

Conselheiros Locais de Saúde representantes da comunidade, DSBRV, 1999 Quadro 30a - Análise avaliativa do trabalho sobre a violência por membro do Fórum Comunitário de Combate à Violência, 1999

Quadro 30b - Análise avaliativa do trabalho sobre a violência por membros da Coordenação Executiva ddo Projeto UNI/BA, DSBRV, 1999

Quadro $30 c$ - Análise avaliativa do trabalho sobre a violência por

Usuários dos Serviços de Saúde, DSBRV, 1999

Quadro 30d - Análise avaliativa do trabalho sobre a violência por

Gerentes de Unidade de Saúde, DSBRV, 1999

Quadro 30 e - Análise avaliativa do trabalho sobre a violência por

Trabalhadores da Saúde, DSBRV, 1999 


\section{GESTÃo PÚBLICA E INOVAÇÃO EM SAÚDE: APRESENTAÇÃO DO PROBLEMA}

\subsection{Introdução}

Rompendo com a tradição de sintetizar um quadro referencial teórico nas introduções, quero apenas destacar aspectos do contexto externo que, servindo como reflexão contraposta ao objeto deste estudo - inovações na gestão pública em saúde numa perspectiva microssocial -, são significativos para entender de que inovações trata o estudo de caso realizado.

As reformas implementadas na administração pública nos paises desenvolvidos (a exemplo da Alemanha, Dinamarca, Espanha, Finlândia, França, Holanda, Inglaterra, Itália, Nova Zelândia, Suécia) ${ }^{1}$ têm sido o foco do debate internacional nos últimos anos. Genericamente denominada "the New Public Management/NPM", as medidas adotadas pelos governos, guardadas as muitas diferenças em cada contexto particular, têm como objetivo final alcançar uma maior capacidade de governo com o menor custo possivel.

Dentre as principais correntes de análise sobre as mudanças no governo e na gestão pública _ que são muito diferentes em termos de suas propostas metodológicas e da possibilidade de operacionalização, mas que

\footnotetext{
1 Sobre as experiências internacionais de reforma na administração pública consultar, dentre outros: Pollitt $C$. Is the emperor in his underwear? An analysis of the impacts of public management reform. Rotterdam: Routledge; 2000; Christiansen PM. A Prescription Rejected: Market Solutions to Problems of Public Sector Governance. Governance. An International Joumal of Policy and Administration 1998; 11(3): 273-295. Para o caso brasileiro ver: Diniz E. Governabilidade, democracia e reforma do Estado: os desafios da construção de uma nova ordem no Brasil dos anos 90. In: Diniz $E$ e Azevedo $S$, organizadores. Reforma do Estado e democracia no Brasil. Brasilia: editora Universidade de Brasilia, 1997.
} 
freqüentemente são considerados em conjunto _, vale ressaltar os seguintes paradigmas:

- A escolha pública (public choice);

- A eficiência pública através de prescrições do setor privado: o novo gerencialismo ou paradigma pós-burocrático e a reinvenção do governo

Para GAULT (1995), a teoria da escolha pública foi elaborada a partir dos estudos de Ostrom em 1972 que buscava nos movimentos teóricos da economia encontrar uma resposta às criticas desenvolvidas para as regras estabelecidas sobre o comportamento racional eficiente. A idéia da escolha pública se baseia na identificação de razões para o comportamento considerado como igual entre pessoas que agem no mercado e aquelas que atuam no processo político. No entanto, nas críticas a este modelo, esse autor destaca a necessidade de aplicar regras econômicas para estudar e definir o comportamento político, desde que se considere as equações adequadas para definir a racionalidade otimizadora de recursos neste âmbito. Para a administração pública, uma das maiores repercussões deste paradigma aparece na proposta de desenvolver um modelo burocrático que possa permitir a maximização do orçamento.

As críticas surgidas a partir da aplicação deste modelo na realidade estadunidense afirmam que não se identifica nenhum caso em que sua aplicação e os resultados propostos possam ser comprovados. Primeiro, porque a manutenção e incremento dos orçamentos nas burocracias não guardam relação predominante com motivos econômicos; segundo, porque as burocracias se orientam muito mais pelas atividades do que pelos resultados, dado às dificuldades para defini-los com precisão; terceiro, porque as organizações não são homogêneas e as pessoas que atuam nelas não são submissas a uma mesma ordem hierárquica e que os arranjos que são processados no seu interior são muito mais complexos do que o previsto neste modelo. Por fim, referindo-se ao modelo da escolha pública 
GAULT ressalta que "muchas de sus limitaciones en la investigación de campo pueden encontrar referente explicativo en los trabajos de teoria de las organizaciones" (1995, p.127). Reforçando as criticas à escolha pública SOUZA e CARVALHO (1999) referem que esta apresenta características muito teóricas e que se baseia em premissas que não podem ser generalizadas.

Quanto ao paradigma da eficiência pública através de prescrições do setor privado como o novo gerencialismo ou paradigma pós-burocrático, este modelo toma como premissa a gestão privada, considerada como vanguarda em questōes de eficiência e atuação em detrimento de um Estado ineficiente. Tem como pressuposto fundamental o fato de que a eficiência se deve à delegação específica de autoridade e a execução de procedimentos e regras uniformes (GAULT 1995). Nesta mesma linha seguem os pressupostos que embasam o paradigma da reinvenção do governo, a partir de estudos desenvolvidos por Osborne e Gaebler sobre casos exitosos na gestão privada (GAULT 1995). Pretendendo ser um novo paradigma social, este propõe "convirtir al gobierno en un espacio de acción eficiente y eficaz, con tecnologias de punta y con actitudes empresariales" (GAULT 1995, p. 131). Isto significa definir como papel do governo apenas a direção estratégica e não a execução de serviços, como no caso da saúde. Para isso o governo deve se orientar pelo mercado, dado que este é um gerador de eficiência, o que exige um politica de direção e informação apoiada em regras flexiveis.

Estas propostas sofrem duras críticas quanto à validade enquanto modelos que podem ser prescritos universalmente; por não aprenderem com a realidade e por não considerar os aspectos relativos às relações interorganizacionais e interpessoais. Para CARVALHO e SOUZA (1999, pp. 193-194) estas propostas não só despolitizam a administração pública como no campo gerencial "deslocam o controle dos gerentes do sistema político para o mercado (Heredia e Schneider, 1998) e se baseiam em premissas 
ideológicas que elevam a importância da gerência e a distingue da política, vista como um entrave à eficiência (Pollitt, 1994)".

Uma particularidade deste processo em países europeus, por exemplo, é a adoção de técnicas e ética oriunda do setor privado com o objetivo de homogeneizar a administração pública com vistas à consolidação da união européia. Além disso, buscam encontrar um caminho próprio na construção de uma nova solidariedade como parte de um estado de bemestar misto ou welfare society (BORGONOVI 2000; COSTA e col. 2000; POLLITT 2000).

O pressuposto era, e continua sendo, 0 de que as regras estabelecidas pelo mercado possam servir para impulsionar uma economia mista de assistência (mixed economy of care), através do estabelecimento de um mercado de serviços sociais. Neste, o setor público pode comprar serviços produzidos por produtores públicos e produtores privados, com e sem fins lucrativos, em "livre" competição entre eles. Este mercado de serviços sociais teria como caracteristicas fundamentais o seu financiamento pelo setor público e a produção dos serviços por entes públicos ou privados. Em verdade, não existiria concorrência entre financiadores, mas somente entre produtores. No entanto, esta possibilidade dependeria do número de produtores existentes e da relação estabelecida entre eles em cada localidade, o que leva a denominar-se este "novo" mercado como quasemercado, dadas as suas peculiaridades (GORI 1998; COSTA e col. 2000).

As novas palavras de ordem da NPM são privatização, transparência, responsabilidade, flexibilidade na gestão, qualidade e orientação para a clientela, o que forçosamente recolocou no plano da discussão temas como descentralização, papel do estado, cidadania, consumismo, eqüidade e direitos. 
O paradigma da NPM é caracterizado por:

- Foco nos resultados em termos de eficiência, efetividade e qualidade nos serviços prestados;

- Gerenciamento descentralizado, principalmente através de agências e organizações públicas, privadas e com caracteristicas híbridas, atendendo às demandas dos clientes e outros grupos interessados;

- Flexibilidade para explorar alternativas na direção e regulação de serviços;

- Orientação para os resultados;

- Busca de eficiência na produção de serviços pelo setor público, principalmente na definição de metas e na criação de ambientes competitivos entre organizações públicas;

- Uso de mecanismos de mercado quando possível, incluindo mecanismos de quase-mercado, para introduzir competição entre provedores públicos; terceirizando serviços ou mesmo privatizando serviços até então produzidos pelo estado.

Quanto às poucas avaliações realizadas internacionalmente sobre as medidas propostas pela NPM, estas apontam para evidências que devem ser consideradas de modo não universal, dado os diferentes pontos de partida e de percurso no processo das reformas implementadas. Para POLLITT (2000, pp. 188-195) os resultados obtidos podem ser categorizados como: 
- Redução ou economia de budget,

- Implementação e aprimoramento de processos;

- Implementação da eficiência;

- Maior efetividade;

- Incremento na capacidade, flexibilidade e resiliência do sistema administrativo em geral.

\subsection{A reforma da administração pública e a gestão pública em saúde no Brasil}

Como parte do conteúdo das reformas na administração pública destacam-se as inovações gerenciais, termo que genericamente significa a introdução de novos instrumentos, práticas e processos que possam implementar os resultados produzidos. Ou seja, inovações gerenciais podem significar muitas e diferentes coisas, mas, em geral, e o Brasil parece acompanhar esta lógica, quando se fala de inovações gerenciais estas são baseadas em experiências já implementadas pelo mercado. Ao lado disso, as inovações são quase sempre relacionadas às mudanças organizacionais/institucionais. Isso significa uma valorização do papel de dirigentes e da adoção da inovação no contexto institucional como propulsora de mudanças (COCKERILL e col. 1999; PINTO 1999; COSTA e col. 2000; BLOCH e BALASSIANO 2000; SARAIVA e CAPELÃO 2000; MENDES 2001)

No Brasil, o paradigma da NPM ganha ênfase a partir do primeiro governo de Fernando Henrique Cardoso/FHC (1994-1997), cujos pressupostos estão explícitos no documento sobre a reforma do aparelho de estado elaborado pela equipe do então ministro Bresser-Pereira (BRASIL 1995; BRESSER-PEREIRA 2000). Ainda que o discurso seja similar às propostas internacionais, o governo brasileiro não explicita de que modo serão assegurados serviços essenciais à população de um pais com as 
fortes desigualdades sociais do Brasil e com poucas cidades com potencial para implementar um quase-mercado de serviços sociais. Para BRESSERPEREIRA (1996) a reforma do aparelho de estado no governo de FHC teria como objetivo de curto prazo facilitar o ajuste fiscal principalmente nos estados e municipios e em médio prazo tornar mais eficiente a administração pública. Para tanto aponta como essencial realizar uma reforma constitucional; implementar atividades do estado através de agências executivas; profissionalizar o servidor público, criando carreiras especificas de dirigentes, e descentralizar os serviços sociais através das organizações sociais.

Dentre as principais estratégias assumidas está a criação de organizações sociais - entes autônomos e flexiveis - particularmente na área da saúde e da cultura, que assumiriam a produção de serviços considerados não exclusivos do estado (BRASIL 1995; BRESSER-PEREIRA 1996; MELO e col. 1998; TANAKA e MELO 2000).

No entanto, na reforma da administração pública implementada no Brasil não se identificam aspectos característicos da instituição pública como fator de produção. Dentre eles se destaca a transferência de recursos não vinculados à concepção da atividade administrativa como um sistema de decisão e ação através dos quais programas políticos se traduziriam em respostas às exigências dos cidadãos. Elevar a relevância de conteúdos técnico-operativos e organizativos, por si só, não significa alcançar resultados positivos. Um outro fator que não se identifica no processo nacional é o investimento na formação das pessoas para o exercício de uma nova função gerencial püblica, considerado como um aspecto fundamental para qualquer reforma (KLIKSBERG 1997; BORGONOVI 2000).

Já DINIZ (1997a) destaca que a relevância da dimensão politica para a eficácia da ação estatal não tem sido considerada nas reformas implementadas no Brasil. Propõe que a reforma do estado no Brasil deve 
considerar os pressupostos que conduzam o país à consolidação democrática. Assim, para essa autora, "essa linha de reflexão impõe a necessidade de definirem novas formas de gestão, através da criação de mecanismos e instrumentos que viabilizem a cooperação, a negociação, bem como a busca de acordos e parcerias (1997, p.120)".

Outro fator importante, que é desconsiderado na proposta governamental, è a implementação das políticas de saúde nos anos 90 , em que se destacam a implantação do Sistema Único de Saúde em 1990², a adoção da "municipalização" com a Norma Operacional Básica/NOB 1/93 e a NOB 1/96 (BRASIL 1993, 1996), como estratégia para descentralizar a gestão pública na busca de eficiência e controle social. A NOB 96 aponta para o fortalecimento da autonomia municipal e estabelece várias estratégias de indução capazes de obter a adesão dos estados e municipios.

Tais propostas se confrontam com medidas da NPM implantadas pelo governo FHC. Dentre elas destaco o caráter que assume a descentralização, enquanto racionalização econômico-financeira do estado, ao mesmo tempo em que apresenta sinais de clara desresponsabilização do governo central frente à saúde, ainda que este siga financiando ações organizadas em programas e projetos desenvolvidos pelos estados e município, mas sob controle financeiro do governo central (COHN 1999; SOUZA e CARVALHO 1999; GUIMARÃES 2000).

\footnotetext{
${ }^{2}$ Sobre o SUS e a Reforma Sanitária brasileira ver. Almeida CM. Reforma Sanitária brasileira: um trajeto de mudanças. Rio de Janeiro: FIOCRUZIENSP; 1993; Almeida CM. As reformas sanitárias dos anos 80: crise ou transição? Rio de Janeiro; 1995, [Tese de Doutoramento, Escola Nacional de Saúde Pública/FIOCRUZ]. Teixeira SMF. O dilema da Reforma Sanitária brasileira. In: Berlinguer G. et al., coordenadores. Reforma Sanitária: Itália e Brasil. São Paulo: HUCITEC/ABRASCO; 1988. P. 195-207. Teixeira SMF. Reforma sanitária: em busca de uma teoria. São Paulo/Rio de Janeiro: CORTEZIABRASCO; 1989; Gerschman S. A democracia inconclusa: um estudo da Reforma Sanitária brasileira. Rio de Janeiro: FIOCRUZ; 1995; Mendes EV, organizador. Distritos Sanitários: o processo social de mudanças das práticas sanitárias no Sistema Único de Saúde. Rio de Janeiro/São Paulo: Hucitec/ABRASCO; 1993.
} 
No contexto de democratização do Brasil, a partir da metade dos anos 80 dois aspectos são tomados como relevantes na discussão, formulação e implementação da chamada Reforma Sanitária brasileira: a descentralização ${ }^{3}$, entendida como um processo de democratização da administração do setor saúde, e o controle social como elemento fundamental para as transformações no sistema de saúde e para a garantia da saúde como direito de todos e dever do estado.

A criação do Sistema Único de Saúde/SUS demandou processos de implantação de novas formas de organização de serviços e ações de saúde suscitando mudanças na capacidade de gestão. A experimentação de novos modelos passou a exigir a profissionalização dos gestores para a saúde e o reconhecimento da gestão como eixo estratégico nesta reorganização.

Concomitante a este processo na saúde, as transformações da gestão de empresas e negócios no mundo ditado pela ordem econômica globalizada têm exigido, inclusive do setor público, mudanças aparentemente radicais na sua administração. No entanto, tais mudanças apontam para a adoção de modelos que visam a atender demandas do mercado e aprofundam, com nova roupagem, aspectos da gestão tradicional, considerando apenas atributos formais da organização.

\footnotetext{
${ }^{3}$ Sobre as várias concepções e usos políticos do conceito de descentralização ver a discussão realizada por Guimarães MCL. Descentralização da Saúde, Interesses e Conflitos Decisórios: 0 processo de decisão nas instâncias colegiais estaduais, Bahia, 1993-1998. Salvador; 2000 [Tese de Doutorado/Escola de Administração. Universidade Federal da Bahia], principalmente o capitulo 1.
} 


\subsection{Inovação e gestão pública em saúde}

Como objeto de estudo, a gestão pública em saúde tem sido analisada em artigos e pesquisas com as mais variadas caracteristicas. Algumas formulam propostas e métodos para gerir serviços de saúde (CECÍLIO 1994, 1997; CAMPOS 2000; MERHY 1997a, 1997b, 2000), outras discutem interfaces entre gestão e trabalho (SCHRAIBER e col. 1999); outros analisam modelos de gestão ou a introdução de inovações gerenciais (FUNDAP 1997; TANAKA e MELO 2000; MENDES 2001).

No entanto, ainda são escassos os estudos sobre o tema das inovações na gestão pública e na gestão pública em saúde, e nesses quase sempre as inovações estudadas são consideradas como decisões institucionais e analisadas no âmbito da organização (FARAH 1997; PINHO e SANTANA 1998; TENÓRIO 1999; BLOCH e BALASSIANO 2000; MENDES 2001).

Os relatos de novas experiências de gestão pública na saúde têm demonstrado que os caminhos seguidos possuem como características principais a introdução de novas relações entre o público e o privado, quase sempre nos aspectos organizacionais e formas de financiamento, enquanto a introdução de formas democráticas de gestão e com participação efetiva da comunidade é considerada ainda utópica (TENÓRIO 1999; FUNDAP 1997).

Tais experiências seguem, portanto, a lógica impulsionada pela reforma do aparelho de estado, na tentativa de melhorar o desempenho dos serviços públicos através da incorporação de instrumentos utilizados na gestão empresarial. Inicialmente são mudanças nas formas de financiamento (pagamento por procedimento para o setor público estatal e privado credenciado/conveniado; incentivos financeiros para o 
desenvolvimento de atividades consideradas essenciais pelo Ministério da Saúde, a exemplo do Piso Assistencial Básico/PAB; terceirização de serviços de apoio como limpeza, alimentação e segurança) e mais recentemente a transferência da gestão de hospitais públicos estatais para as chamadas organizações sociais de saúde.

Quanto às inovações nas organizações, tradicionalmente estas são estudadas tendo como referencial teórico o modelo de Rogers (1983) citado por COCKERILL e col. (1999 p.191). Focado na perspectiva individual, este modelo analisa a adoção e difusão de inovações, aprioristicamente definidas, ao longo do tempo. Mesmo outros modelos de análise sobre a difusão e adoção de inovações quase sempre não incluem variáveis sobre atributos percebidos ou consideram a inovação como uma variável dependente apenas do contexto organizacional (COCKERILL e col. 1999).

Por que então estudar inovações na gestão em saúde num estudo de caso microlocalizado e tendo como referência o cotidiano e as experiências vividas por gestores da saúde, considerando que tais gestores não são apenas os que a instituição de saúde legitima?

Primeiro, para contribuir com respostas para as questōes relacionadas ao tema do gerenciamento da saúde, identificadas ao longo do meu exercicio de funções técnicas em instituições públicas de saúde. Uma questão que sempre se impôs foi de que as pessoas eram realizadoras de açōes e atividades que davam "sentido e fim", apesar das instituições e de suas politicas, muitas vezes contrárias ao atendimento de demandas elementares. Para compreender a possibilidade do fazer, pelas pessoas, apesar das nossas instituições de saúde, seria preciso usar uma abordagem que deslocasse o foco do plano macroinstitucional para o plano microssocial num estudo de caso particular. 
Segundo, para contribuir com a análise das possiveis transformações na gestão pública de saúde, através de experiências locais e cotidianas, isto é, experiências cotidianas e que não fazem parte, necessariamente, de um conjunto intencional de intervenções, mas que surgem de iniciativas de pessoas/grupos em respostas a situações concretas.

Terceiro, porque há uma necessidade social de entender a realidade do processo de gestão de um ponto de vista não apenas institucional, mas confrontando as diferentes vozes dos gestores e trazendo à tona a forma como cada um deles pode estar contribuindo para o desenvolvimento da gestão dos princípios estabelecidos pela Constituição Federal e pelo SUS. Assim, pode ser confrontada a tese defendida por Campos (citado por CECÍlIO 1994, p. 269) de que a renovação da gestão no público e na saúde se dará através de sujeitos potencialmente interessados, penetrando-se o campo da investigação da gestão em saúde enquanto trabalho vivo em ato (MERHY 2000), capaz, portanto, de criações que ultrapassem o instituído pela instituição/organização.

Quarto, também contribuir para a compreensão e aceitação de que a criação da inovação na gestão da saúde pode ser produzida na experiência da vida diária, ainda que seus resultados não sejam considerados como modelos reproduziveis em qualquer realidade.

Quinto, para contribuir na difusão de experiências do presente que, pelo caráter circunscrito ao espaço da micropolítica, muitas vezes perdem-se na dimensão geográfica e histórica do país.

Sexto, explorar fronteiras na busca de outras bases teórico-empiricas nos estudos de inovação na gestão em saúde.

A partir dos pontos sintetizados busquei responder à hipótese preliminar de que atores/gestores da saúde, mesmo em situações adversas 
e em espaços microssociais, seriam capazes de criarlidentificar inovações na gestão real, e não meramente formal, da saúde.

As questōes motivadoras explicitadas abaixo serviram como ferramentas para a operacionalização da investigação:

- Que inovações são identificadas no processo da gestão em saúde no Distrito Sanitário Barra/Rio Vermelho?

- O que caracteriza tais inovaçōes?

- Quais as repercussões causadas pelas inovações identificadas?

- Como são avaliadas na perspectiva dos atores locais?

Tendo como base as questões anteriores foram definidos como objetivos da investigação:

\section{Objetivo Geral:}

- Analisar inovações na gestão da saúde da perspectiva dos atores locais.

\section{Objetivos Específicos:}

- Identificar inovações na gestão em saúde num distrito sanitário.

- Interpretar as caracteristicas e repercussões das inovações identificadas.

- Analisar fatores locais da organização e da micropolitica institucional que interferem nas inovações identificadas.

- Analisar as enunciações avaliativas dos atores locais sobre as inovações identificadas. 
A atitude fundamental no processo da investigação foi de manter a crença de que as coisas não são o que parecem, e, por isso, existe sempre alguma possibilidade de que, na desordem aparente do sistema público de saúde, estejam em desenvolvimento inovações na gestão. Isto foi feito pela observação, identificação, interpretação e análise de aspectos "anômalos" ou que expressassem alguma forma de desvios no contexto políticoinstitucional local e na gestão formal.

Tais "anomalias" foram quase sempre identificadas como movimentos, concepçōes e processos que enfraquecem os modelos e estereótipos deterministas (MORIN 1998) com os quais enxergamos a realidade. Concordo com autores que defendem o governo como algo exercido por distintos sujeitos protagonistas, inseridos em espaços sociais diferentes (MATUS 1993; MERHY 1997a, 1999) e a capacidade criativa como uma ocorrência cotidiana (PEILE 1994). E aceito que a organização de saúde não está constituída apenas pelo seu aspecto institucional ou da "consolidação burocrática" e sim, também, pelo agrupamento de interesses comuns de sujeitos sociais (URIBE RIVERA 1989, p. 93).

Esta investigação considera particularmente 0 processo de identificação e avaliação das inovaçōes, segundo a perspectiva de atores/gestores locais. Ainda que não se detenha em sua disseminação e adoção, não deixa de indicar alguns elementos nesta direção. Até porque é quase impossivel tratar de um desses aspectos isoladamente. Entretanto, não existiu a preocupação de cumprir o arcabouço de aspectos que classicamente permeiam estudos de inovações na gestão, quase sempre compreendidas como a introdução, pela alta direção, de novos produtos, instrumentos, técnicas ou processos.

Neste estudo de caso sobre inovações na gestão pública da saúde no Brasil, as inovações examinadas caracterizam-se por terem sido identificadas pelos atores/gestores locais, participantes do processo de 
gestão, num conceito ampliado do que tradicionalmente se considera "gerente da saúde". Assim, adotei o conceito utilizado por MERHY (1997a, 1997b, 1997c, 2000), de que são gerentes todos aqueles que participam da produção e da utilização de serviços e ações de saúde. Tal perspectiva é coerente inclusive com a compreensão de uma organização como uma construção social de redes e de negociações (BROWN 1999), o que nos leva a compreender a organização como o resultado de processos formais e informais desenvolvidos e interpretados por atores diferentes.

Também é importante compreender que a trajetória prática e teórica adotada na investigação tenta identificar nas inovações novas formas de conhecimento sobre a gestão pública em saúde, como apontado por LEITE e col. (1999, p. 47), isto é:

- Ampliar as fronteiras da identificaçāo e análise de inovação e gestāo pública na saúde;

- Adotar uma pluralidade metodológica;

- Contribuir na auto descoberta de talentos e sua utilização num trabalho coletivo como o da gestão em saúde.

Portanto, as inovações analisadas não podem ser compreendidas como inovações definidas pela organização de saúde, ainda que possam ser adotadas por elas e/ou com elas mantenham estreita relação. Isto significa "(...) contrastar o modelo de difusão, de clara matriz mecânica ou epidemiológica, que tem sido amplamente utilizado para interpretar tanto a inovação quanto à sociedade em si" ${ }^{4}$ (GHERARDI 1998, p. 65).

Neste sentido, as inovações são analisadas no seu processo de identificação e utilização pelos atores locais e são modificadas e adaptadas aos próprios interesses dos diversos atores/gestores da saúde. Não

\footnotetext{
${ }^{4}$ Tradução minha do italiano: (...) contrastare il modello della diffusione, di chiara matrice meccanica o epidemiologica che è stato ampiamente usato per interpretare tanto l'innovazione quanto l'implementazione o la società stessa".
} 
guardam, conseqüentemente, o significado de mudança intrinsecamente atribuido ao conceito, principalmente adotado por Schumpeter (1961), citado por MENDES (2001, p. 35)

Isto não quer dizer, necessariamente, que as inovações estudadas sejam consideradas como meros fenômenos capazes de apenas contribuir para mudanças nos próprios atores sociais. Também não se pode tomar as inovações estudadas como uma produção utilitária do senso comum de determinados atores sociais, o que seria considerá-las como a única possivel realidade existente (BAUMAN 1977, pp. 130-131).

As inovações são analisadas como fenômenos não rotineiros e irregulares, "os quais, em certo sentido, podem ser considerados como um vislumbre do futuro ou de uma realidade alternativa" (BAUMAN 1977, p.157). Assim, distanciam-se de inovações que buscam maior eficiência (COCKERILL e col. 1999; ANDREAZZI e TUNA 1999; MENDES 2001), já que os significados e resultados identificados não se adaptam a padrões preestabelecidos e não podem ser analisados apenas como mudança positiva.

Reconhecendo o fato de que não existe um referencial teórico consistente sobre a categoria inovação na gestão pública, como observam PINHO e SANTANA (1998), realizamos um levantamento bibliográfico tentando encontrar relatos de experiências de implantação de "inovações" na gestão pública e na gestão pública da saúde no Brasil. No entanto, o material identificado revelou quase sempre uma concepção de inovação num enfoque econômico ou a adoção do termo "inovação" referindo-se a mudanças ou estratégias no ato de governar, a exemplo das experiências subnacionais relatadas pelo Programa Gestão Pública e Cidadania da Fundação Getúlio Vargas de São Paulo (FARAH 1997; TENÓRIO 1999). No contexto atual, com os novos papéis assumidos pelos municipios brasileiros, a inovação na gestão toma-se uma estratégia para procurar dominar os 
problemas sociais, hoje sob a responsabilidade cada vez maior destas instâncias (PINHO e SANTANA 1998, p. 6).

Além disso, predomina uma perspectiva de limitada possibilidade de inovação (e portanto, do exercicio criativo do trabalho gerencial) em instituições públicas como a brasileira, cujas características não favorecem tal processo. Em particular, as instituições públicas de saúde são plenas de barreiras à inovação. Dentre estas pode-se enumerar, a titulo ilustrativo, a baixa descentralização e desarticulação do processo de gestão existente; a falta de profissionalização dos gestores; o incipiente controle social da gestão; a predominância de elementos da administração clássica, e a pouca comunicação entre os sujeitos interessados e participantes do processo de gestão.

Um dos desafios da investigação foi, portanto, contribuir para a superação da ausência de um quadro teórico consolidado e para a ampliação dos modos de identificar e interpretar as inovações na gestão em saúde, buscando-a na perspectiva de diferentes atores locais.

A palavra "inovação" quase sempre é utilizada para indicar uma intencionalidade para a introdução de estratégias de mudanças. Este conceito não considera as inovações produzidas na base de um sistema, que freqüentemente passam despercebidas, além de anular a possibilidade de mudanças trazidas pela criação de inovações (LEITE e col. 1999, p. 42).

DE SARDAN (1995) cita conceitos clássicos de inovação desenvolvidos nos anos 30 , todos eles relacionados com os meios de produção e identificados a partir do processo de produção. São eles: inovação como um novo produto; como um novo método ou modo de produção; como um novo mercado; e como uma nova organização da produção. 
Nesse sentido, a inovação pode ser compreendida como uma junção de técnicas e saberes ou de modelos de organização inéditos implantados sobre técnicas, saberes e modo de organização num determinado lugar. Desse modo a inovação é interpretada como algo geralmente importado e que permite a "criação" do novo para um espaço mais local, avaliado como o espaço em que a inovação seria incapaz de ser criada. Assim, a inovação se restringiria a inovações de ordem técnica e os estudos realizados sobre o tema quase sempre estão relacionados com a introdução de novas tecnologias. Com base no paradigma tecnológico, as inovações se processariam seletivamente, seguindo uma direção previamente definida (AMADEO 1989) e limitando a sua introdução de fora para dentro e por atores com mais poder.

HEYDEBRAND (1983, pp. 306-307) ao considerar as organizaçōes como uma forma de práxis e, por conseguinte, muito mais um processo nãocontínuo de organização do que uma estrutura, define os conceitos de práxis organizacional (referida não somente a transformações técnicas do meio ambiente ou solução prática de problemas, mas também como um processo consciente de autotransformação de atores coletivos); comportamento organizacional (seqüências objetivas e causais nos movimentos e respostas da organização devido ao impacto de forças externas e determinantes) e ação organizacional (atividades relativamente mais subjetivas de uma organização direcionada a outra organização). Tudo isso para relacioná-las com sua tipologia de inovações:

a) inovações organizacionais, que são desenvolvidas ou adotadas meramente como uma adaptação ao ambiente;

b) inovações nas açōes organizacionais, que tomam a forma de estratégias conscientes de transformação das próprias condições da ação; 
c) inovações nas práticas organizacionais, que envolvem processos coletivos de auto-transformação ou de auto-organização.

MOTTA (1993) afirma que a inovação no mundo da organização é sempre especifica e coletiva. Esta muda necessariamente os hábitos, interesses, valores e crenças estabelecidos nos produtos ou serviços, mas também no processo de decisão e operação organizacional. Isto parece claro quando se analisa uma organização empresarial, interessada em competir e obter lucros num mercado cada vez mais amplo e competitivo. As empresas, em geral, demonstram maior grau de interesse pelos aspectos da criação de inovações traduzidas em novos produtos. No entanto, quando se observam as organizações públicas, a criatividade e a inovação não parecem ser objeto de interesse. A dificuldade em investigar inovaçōes é, portanto, ainda mais acentuada no setor público.

Estudos desenvolvidos sobre o tema em organizaçōes quase sempre tomam a inovação como análoga ao processo de mudança organizacional (ACUÑA e FERNÁNDEZ 1995), o que torna este conceito ainda mais complexo. Neste sentido, a inovação, considerada como um processo organizacional, estaria estritamente relacionada com o processo gerencial.

MOTTA (1993) faz referência à natureza organizacional e gerencial da inovação. No primeiro caso, a inovação é considerada como um processo organizacional sistêmico, global, cultural e conflituoso e como uma decisão organizacional. No segundo caso, numa perspectiva moderna da teoria gerencial, a inovação está relacionada também com características individuais, além das organizacionais e do seu contexto externo. No entanto, reconhece que a produção da inovação gerencial, ainda que oriunda de uma idéia individual, só é considerada como tal quando se torna um ideal coletivo. "A transformação da criatividade em inovação é, em grande parte, um processo de transformar ideais individuais em ideais coletivos. As idéias 
novas não são, por si mesmas, suficientes para produzir inovações; é preciso que elas ultrapassem os limites do desejo individual e se tornem preocupações coletivas no contexto organizacional" (p. 232). Para o desenvolvimento, aceitação e implantação da inovação, portanto, são necessárias mudanças nas condições organizacionais para o uso prático de inovações produzidas no processo gerencial. Este autor, ainda que identifique a gestão como uma arte permeada por componentes cientificos e racionais, ao lado de elementos imprevisíveis, intuitivos e relativos à interaçāo humana, não avança no reconhecimento de sujeitos nãoinstitucionais como capazes e participantes do exercicio da "arte da gerência".

FARAH (1997), ao analisar as iniciativas inovadoras na administração subnacional no Brasil, o faz de um ponto de vista da configuração de novas políticas públicas (tipo e conteúdo) e do processo político e gestão destas políticas, incluindo novas formas de gestão e de processos decisórios.

Já ACUÑA e FERNÁNDEZ (1995) desenvolvem uma tipologia das mudanças organizacionais consideradas como de primeira e segunda ordem. As de primeira ordem referem-se às mudanças no sistema, enquanto as de segunda ordem seriam "(...) alterações mais radicais, destinadas a modificar o sistema propriamente dito. Nelas se examinam as práticas correntes de trabalho, as crenças e os pressupostos básicos que sustentam essas práticas" (1995, p. 83). Estes autores também referem-se a mudanças incrementais (como reformular estruturas organizacionais ou introduzir uma nova tecnologia) e estratégicas (que visam a mudança, nos aspectos fundamentais, da organização inteira).

Tais conceitos, no entanto, reforçam a visão hegemônica da inovação apenas possivel de se manifestar num sistema social estruturado e não sobre grupos atomizados de indivíduos (DE SARDAN 1995, pp. 78-79). Nesta direção, pode-se refletir que para a difusāo da inovaçāo este 
pressuposto seria válido. Mas ele o será para a produção da inovação em si?

ALENCAR (1995, pp. 104-105) apresenta os principais tipos de barreiras à inovação categorizadas em cinco grupos: 1. Estruturais (como a excessiva formalização de regras e procedimentos e a centralização do poder); 2. Sociais e Politicas (relativas às normas e influências de poder dentro das organizações); 3. Processuais (existência de procedimentos e regulações que inibem a inovação, como o desestímulo à realização de tarefas de forma diferente do habitual); 4. De recursos (como carência de profissionais, de recursos financeiros ou informações); e 5. Individuais ou Atitudinais (relativas aos membros individuais da organização).

Ainda que algumas das tipologias e elementos destacados tenham sido tomados como orientadores no trabalho de campo, o predomínio de concepções de inovação que não contemplavam o que pretendiamos investigar como inovação na gestão em saúde nos levou a buscar outras fontes de referência, além de identificar a própria definição de inovação pelos gestores.

De início queremos salientar que consideramos a inovação como um ponto de partida que revele mudanças sociais e que pode significar, para a investigação da gestão em saúde, a possibilidade de comparar processos que contribuam para a transformação necessária na saúde. Esta perspectiva conta com o suporte de Campos, ao discutir projetos de mudanças na saúde, quando afirma que se deve "negar o suposto determinismo do global sobre o particular, do econômico e do político sobre as instituições e destas sobre as pessoas" (CAMPOS 1994, p. 31).

Isso porque concordamos que existe uma estreita relação entre a produção da inovação e a criatividade, considerada como um fator essencial do processo, "constituindo-se no componente ideacional da inovação, 
enquanto esta englobaria a concretização e aplicação das novas idéias" (ALENCAR 1995, p. 101).

No entanto, novas idéias nem sempre são aceitas ou consideradas inovadoras pela sociedade, instituiçōes e grupos sociais específicos. Estas também são dependentes da referência que se adota para o reconhecimento ou aceitação da inovação, no sentido de que esta deve guardar relação com os valores da sociedade ou grupos sociais em questão. Foi assim que adotamos a inovação quando identificada pelo grupo de gestores institucionais e não-institucionais, isto é, reconhecidos ou não, do ponto de vista da instituição saúde, como gestores da saúde em seu território.

O reconhecimento de inovações parece não prescindir da sua aceitação pelos sujeitos de um lugar. Esta aceitação tem um significado que ultrapassa a mera identificação ou adoção da inovação, mas exige sua apropriação, num processo que implica identificação, interiorização e interpretação da inovação (DE SARDAN 1995, pp. 83-84). Além disso me permite considerar que os efeitos da inovação serão diferentes para cada lugar e para cada grupo de individuos envolvidos neste processo.

Isto também me conduz ao reconhecimento de que, para além de sua indexaçāo social, ou seja, para além da constatação de que a inovação surge em um sistema social estruturado e não sobre um grupo isolado de individuos, a inovação tem um caráter que é determinado pelos seus criadores/portadores. Assim, os efeitos causados na estrutura social local dependem de quem sejam os criadores/portadores da inovação identificada. Por conseguinte, os efeitos causados pelas inovações são sempre imprevisiveis e impermanentes. Conseqüentemente, portadores diferentes vão gerar, necessariamente, efeitos diferentes.

Isto é o oposto da concepção de inovação vigente que a relaciona estritamente com o paradigma tecnológico e elimina, portanto, a 
possibilidade de o local subverter a "ordem" organizacional e a importância hierárquica.

Quanto ao objeto de estudo - inovação na gestão reconhecida por atores locais -, este foi investigado através dos processos de governo dos diversos gestores. Isso porque consideramos que a organização da saúde deve ser abordada de modo dialético, por representar "um arranjo social, sempre provisório, que se define a partir da multiplicidade de interesses contraditórios dos indivíduos e grupos organizacionais, supondo a possibilidade do entendimento" (Benson citado por URIBE RIVERA 1995, p. 100). Isto significa reconhecer que esta abordagem considera que a atuação dos sujeitos guarda limitações estabelecidas pelo seu contexto.

No estudo de caso, a inovação é compreendida como um processo descontínuo, capaz de romper paradigmas tradicionais vigentes e de reconfigurar saberes e poderes (LEITE e col. 1999). A mudança social é, assim, um componente essencial para a compreensão da inovação estudada. A inovação não tem em si a capacidade de resolver problemas, mas pode ser compreendida como espaço de ação tática e de intercâmbio de problemas como definia MATUS (1993). Principalmente consideramos que a inovação na gestão em saúde, como foi aqui estudada, pode ser um ponto de partida possivel para tais mudanças e não deve ser vista como um objeto distinto em si mesma. Este foco permite avanços comparativos e, portanto, sempre relativos.

Aqui, a inovação não foi considerada como um fenômeno endógeno produzido na base da organização e identificada através de formas técnicas rituais ou organizacionais. No entanto, entendemos que a inovação, para ser aceita, deve ter alguma vantagem sobre 0 instituido, ter capacidade de suscitar adesão e ser comunicável e, no caso de ser disseminada no âmbito organizacional, guardar alguma compatibilidade com o sistema técnicopolítico existente (DE SARDAN 1995, pp. 83-88). 
Também busquei dimensionar nas experiências de gestão em saúde no âmbito local inovações que ultrapassassem a lógica da mera racionalidade econômica que permeia as transformações mundiais dos sistemas de saúde e da incorporação de instrumentos e lógica empresarial no setor público.

Posto isto, quero reforçar que a investigação sobre as possiveis inovações na gestão em saúde é também uma perspectiva de resgatar o que SANTOS (1996, pp. 251-265) afirma sobre os lugares e o cotidiano como capazes de produzir novos significados por possibilitar uma nova interação mediada pela ação comunicacional. Estes elementos permitiriam, mesmo aos mais pobres e destituidos de poder em ato, construir "brechas" em que se constitui novas articulações práticas e novos usos na vida social e afetiva.

Por isso, a inovação investigada tem um caráter de transformação, o que não está contido no âmbito do que apenas pode ser considerado como novidade. A inovação é considerada como parte de um processo de mudança e procurada nas fissuras institucionais, numa compreensão de que o cotidiano pode subverter a organização e sua "vida normal". Nesta direção, reforça-se o papel, na produção da inovação, dos atores ditos ordinários, distinto do papel do ator institucional com quem interagem nesse processo. Isto abarca a compreensão de que a inovação não trará, em si mesma, uma capacidade de ser replicada no interior da organização.

As inovaçōes estudadas são consideradas como movimento, pois possuem características criadoras e adaptadas ao contexto e às condições objetivas dos atores envolvidos nesse processo. Este movimento não pode, no entanto, ser compreendido como mero espontaneísmo ou uma resposta simplista a uma realidade complexa e desordenada. Deve ser compreendido no bojo do que se identifica como movimentos ligados a um modelo 
inspirado pela autonomia, que "(..) apela também para a criatividade, a eficácia crítica, a responsabilidade, a recusa à inércia. Convida a encontrar a força da tradição emancipadora no sentido de utilizá-la na construção de uma sociedade autogovernada, onde a autonomia individual e a coletiva se sustentem e se mantenham, onde a instituição da sociedade esteja renovada e onde as significações imaginárias sejam suficientemente vivas para poder formar, inspirar e animar os individuos" (BALANDIER 1997, p. 244).

\subsection{Delimitando o estudo de caso}

A opção por localizar o estudo empírico num espaço concreto e microlocalizado como o Distrito Sanitário Barra/Rio Vermelho apóia-se na valorização do espaço local para o objeto da investigação. Isto é, o espaço local é ao mesmo tempo uma totalidade, significando à sua maneira o mundo e sendo também diferente dele. O espaço local pode ser visto (...) "como um intermédio entre o Mundo e o Indivíduo" (SANTOS 1996, p. 251) e como uma realidade dinâmica, tensa e instável, que é criada e recriada a cada momento na ação dos atores e que pode ser apropriada com profundidade e compreendida imediatamente.

Dado que queria analisar as possiveis inovações na gestão, num território delimitado, numa perspectiva dos diversos atores/gestores e no tempo mesmo em que tais inovações podiam estar sendo criadas/identificadas como experiências emergentes, a abordagem qualitativa e o estudo de caso reafirmaram-se como pertinentes. Além disso, a análise de conteúdo permitiu incorporar elementos do contexto identificados na linguagem dos diversos atores participantes. Procurei também contribuir não só com uma ampliação do conceito de inovação, como dos modos de estudar esta questão. Isto porque as inovações estudadas foram sempre interpretadas como portas de entrada para a 
produção e compreensão de desvios na gestão pública da saúde, numa perspectiva para além do controle/decisão da organização formal.

O espaço de desenvolvimento da pesquisa está contido no território do Distrito Sanitário Barra/Rio Vermelho, localizado no município de Salvador, Estado da Bahia, Brasil. Esta escolha está baseada na minha vinculação profissional com este distrito considerado como portador de peculiaridades como a presença sistemática de atividades desenvolvidas pelos cursos da área da saúde da Universidade Federal da Bahia, caracterizando-se como um distrito sanitário docente-assistencial.

A escolha do Distrito Sanitário Barra/Rio Vermelho também guarda relação com a implementação do Projeto UNI/Bahia (Uma Nova Iniciativa em Educação e Saúde) em seu território, por adotar princípios estimuladores de novas iniciativas na formação de profissionais da saúde, na organização, gestão e prestação de serviços, e na relação entre universidade, serviços de saúde e população residente no território-distrito (KISIL e CHAVES 1994).

A opção por um espaço microlocalizado num estudo de caráter exploratório foi assumida como a mais adequada, considerando a diversidade da realidade brasileira. No entanto, reconhecemos que este âmbito mantém grande complexidade por se constituir de lógicas e processos distintos e por refletir, em sua totalidade, o contexto políticoinstitucional da saúde no municipio de Salvador.

Uma preocupação na definição do objeto foi sua inserção contemporânea, o que leva à circunscrição temporal da investigação abrangendo o periodo de 1997/2000, correspondente ao mandato da administração municipal, bem como a cobrir o período de consolidação do próprio Projeto UNI/BA na área selecionada. A adoção deste período permitiu analisar as inovações gerenciais na saúde no distrito sanitário, no tempo mesmo de sua criação. Os riscos de desenvolver uma investigação 
num tempo real são ainda maiores, mas consideramos que tal escolha está fundamentada na opção metodológica assumida, através do estudo de caso

Por fim, para orientar a leitura, organizei o texto em seis partes, buscando relacionar, do modo menos fragmentado que me foi possivel, as sinteses teóricas com a descrição dos achados e a análise realizada, pelos atores/informantes e por mim mesma.

A primeira parte trata da apresentação do problema através da introdução ao estudo com a discussão teórica do contexto externo à investigação além de reflexões teórico-empíricas sobre o conceito de inovação, justificativa, delimitação do objeto e definição dos objetivos

A segunda discute as bases teórico-metodológicas, onde descrevo e analiso a trajetória, técnicas e desenho analítico utilizado, destacando algumas liçōes aprendidas no percurso. Espero ter deixado clara a felicidade que foi confirmar plenamente a idéia de que um método é sempre uma aparência enganosa, pois a verdadeira descoberta é que é, ao final, a descoberta de um método (LÉVY 1999, p. 27).

$\mathrm{Na}$ terceira parte apresento e discuto o contexto externo ao território do estudo de caso, isto é, das questōes relativas à reforma do aparelho de estado no Brasil, o processo de descentralização e da municipalização na saúde e os cenários de discussão sobre a gestão em saúde.

$\mathrm{Na}$ quarta, descrevo e analiso o contexto interno ao distrito sanitário estudado, trazendo não só o panorama das politicas locais de saúde relacionadas com o objeto da investigação assim como aspectos analiticos e avaliadores da gestão local em saúde. Destaca-se nas análises a perspectiva dos atores/gestores informantes da pesquisa.

A quinta parte contém a descrição e análise das quatro inovações identificadas. Para cada inovação extraí características peculiares para que 
fossem analisadas com destaque. Tais destaques não seguem uma uniformidade temática, dado que surgiram dos próprios achados, dos quais foram destacadas por serem consideradas relevantes e significativas.

Por fim, na sexta parte, apresento uma sintese final de comentários e conclusões, numa tentativa de refletir sobre os achados mais significativos à luz do referencial teórico que me conduziu no estudo e nos quatro anos de doutorado.

Espero ter sido capaz também de transmitir aos leitores que "é, portanto, verdadeiro, em certo sentido, que só há poesia nos poemas (como só há aventura nos romances, intriga nas narrativas, dramatização no teatro) e que um gesto talvez deva o essencial de sua beleza ao talento com que é relatado" (GALARD 1997, p. 31). 


\section{BASES TEÓRICO-METODOLÓGICAS}

\subsection{Trajetória}

Para o alcance dos objetivos, a investigação se defrontou com o desafio de construir uma proposta metodológica que permitisse o desenvolvimento de um estudo sobre pressupostos não necessariamente reconhecidos como bem-sucedidos, como aqueles tradicionalmente esperados na gestão pública em saúde.

Para um mapeamento teórico inicial sobre o tema, consultei diversos bancos de dados e bibliotecas informatizadas da Universidade de São Paulo, através de busca com palavras-chave (inovação; gestão; saúde; administração pública). No entanto, constatei que basicamente não existem produções em que se aborde a questão/tema das inovações especificamente na gestão em saúde. Em bancos de dados na área de administração em geral, o tema foi encontrado com um enfoque econômico ou com inovações na gestão consideradas como a introdução de novas tecnologias/produtos ou introdução de instrumentos e técnicas da gestão empresarial no setor público. O diferencial registrado diz respeito a algumas publicações sobre as inovações na gestão subnacional com caracteristicas democráticas (PINHO e col. 1997; BLOCH e BALASSIANO 2000; SARAIVA e CAPELÃO 2000), mas com um enfoque institucional e macroestrutural.

Como a questão norteadora da investigação é composta de elementos diferenciados, ou seja, com um foco direcionado para um espaço microlocalizado; considerando gestores da saúde não apenas os atores nomeados institucionalmente; $e$, ainda, que inovações podem estar sendo criadas mesmo em contextos políticos/institucionais adversos, ficou difícil encontrar referências, na área da gestão pública da saúde, com tais caracteristicas. Como esperado desde o inicio, comecei uma busca entre autores das ciências sociais para encontrar as "pistas" necessárias para o 
desenvolvimento da investigação. Isto foi feito através de disciplinas cursadas; de participação em sessōes do núcleo de estudos em psicologia social e saúde da PUC/SP e na aplicação da técnica de "bola de neve"5 sobre as referências bibliográficas de livros e artigos lidos. Creio que fui privilegiada, pois, mais do que saber escolher bem os autores que deveria ler fui escolhida por vários deles, que me cairam nas mãos, por exemplo, através de matérias em jornais ou por sugestão de pessoas com quem falava sobre o tema.

Tudo indica que este processo foi adequado e consistente porque o arcabouço teórico utilizado na elaboração do projeto de pesquisa foi útil para o desenvolvimento do trabalho de campo e mostrou coerência com os resultados da análise.

Mas do que uma escolha teórica a priori, o que conduziu a apreensão teórica foi uma permanente indagação quanto à capacidade das pessoas para criarem nas suas práticas, mesmo em situaçōes desfavoráveis, e uma determinação em procurar enxergar e entender o diferente, discrepante, e mesmo os "fatores negativos" ou atípicos.

Deste modo, as idéias de FEYERABEND (1991, 1991a, 1993) quanto a um possivel "anarquismo" teórico e metodológico - na verdade um reconhecimento da capacidade criativa de qualquer ser humano e a crença de que qualquer idéia pode ser capaz de contribuir para o desenvolvimento deste conhecimento - foram uma fonte de inspiração permanente para a abordagem metodológica nesta investigação.

\footnotetext{
${ }^{5}$ A técnica de bola de neve (snow ball) refere-se à identificação de informantes-chave através da indicação de outros informantes durante a própria coleta de dados.
} 
Tentando sistematizar os principais argumentos utilizados por este autor, apresento aqueles que mais de perto contribuiram para a identificação e análise das inovações na gestão aqui estudadas:

- As investigações não devem obedecer a modelos gerais e uniformes e que são constituidas de movimentos nem sempre conhecidos por quem as operam (FEYERABEND 1993, p. 11);

- O processo de criação de alguma coisa e a criação e compreensão plena de uma idéia correta da coisa se processam de modo indivisivel e guiado também por uma vaga exigência, como em uma paixão (FEYERABEND 1993, p. 32);

- Não se deve aceitar o conformismo cognitivo, que, longe de ser um privilégio de camadas ditas "inferiores" da sociedade, afeta também a intelectuais e cientistas. Como diz MORIN (1998, pp. 34-35), "há mais opiniões pessoais diante do balcão de um café do que num coquetel literário";

- Para maximizar a análise deve-se adotar uma metodologia pluralista que permita a comparação de idéias e destaque os contrastes identificados. Isso porque todas as metodologias são limitadas a um contexto preciso e ao olhar do sujeito do conhecimento e tais limites devem ser demonstrados (FEYERABEND 1993, pp. 35-39);

- O conhecimento, em todas as suas fases, é condicionado por experiências anteriores, que mesclam de sofisticadas teorias a expectativas e disposição do próprio sujeito (FEYERABEND 1991) 
Estes argumentos justificam a adoção de várias bases teóricas cujas características permitiram a criação de uma abordagem metodológica adequada aos objetivos da investigação e de uma análise em que este referencial foi utilizado de modo complementar, na medida em que contribuía para explorar e gerar formas e meios de compreender o objeto de estudo.

\subsubsection{Abordagens}

Dentre as perspectivas teóricas inspiradoras desta investigação, a etnografia foi tomada inicialmente, por ser considerada uma teoria com uma contribuição essencial para as ciências da organização (DUPUIS 1996), por permitir a observação direta e em longo prazo das ações dos homens, no local onde se criam e realizam tais ações. Esta teoria, enquanto um modo de pensar sobre o outro, foi utilizada articulando a interação social e as práticas dos atores, através dos conteúdos e significados destas relações.

Através de tais estratégias foi possivel identificar e descrever a produção, percepção e interpretação de estruturas significantes para a identificação de inovações, mantendo-me em uma conversa permanente com os atores locais, baseada nas experiências pessoais (minhas e deles) e na compreensão de que não podiam ser separados o modo de representação e o conteúdo substantivo das inovações identificadas (GEERTZ 1995). Isto permitiu também, no estudo das inovações na gestão, articular os contextos de produção da inovação entre a interação social, as práticas dos sujeitos (gerentes e outros) e os significados diversos destas práticas.

No entanto, foi a etnometodologia (a este respeito ver as diferentes abordagens de HAGUETTE 1987; PATTON 1990; BENSON and HUGHES 1991; BUTTON 1991; MINAYO 1993; MORSE 1994; GARFINKEL and SACKS 1995; GIDDENS 1996, 1998; DE CERTEAU 1998) a opção tẹórica 
fundamental na investigação. Esta foi considerada não como uma metodologia especifica, mas como a ciência da razão sociológica prática (MUCCHIELLI 1995, pp. 73-77) e como o estudo dos métodos utilizados pelas pessoas, da ação e raciocínio práticos (LIVINGSTON 1987, p. 3). Essa adoção foi de utilidade na identificação e na interpretação das inovações, principalmente dos aspectos relativos à sua natureza. $\mathrm{Na}$ investigação, a etnometodologia serviu como inspiração teórica fundamental no caminhu apontado por COULON (1996, p. 3), que diz que sua importância teórica e epistemológica está em que opera uma ruptura radical com os modos tradicionais de pensar a sociologia e se constitui numa perspectiva de pesquisa e numa nova postura intelectual. Isso porque, dentre outros aspectos, a etnometodologia considera que a linguagem descreve $e$ constitui, ao mesmo tempo, a realidade social

Iniciada nos anos 30 na Universidade de Chicago, a etnometodologia é desenvolvida posteriormente por Garfinkel, a partir das bases da fenomenologia. Este autor buscou a experiência direta com atores sociais, compreendendo que somente deste modo se poderia apreender a realidade vivida por estes. Para ele, esta teoria possibilita compreender a vida cotidiana e prática, o que permitiria, nos estudos sociológicos, também compreender a interpretação da prática dos atores sociais, fundamental para o entendimento da vida social. Destaca a interpretação dada pelos sujeitos para a experiência vivida e esta interpretação como constituinte do mundo social.

A etnometodologia agrega modos diferentes de reflexão, a depender do autor adotado. Para PATTON (1990), a etnometodologia é uma nova abordagem da sociologia, e deve ser entendida como uma nova concepção teórica dos fenômenos sociais. O foco da etnometodologia é a rotina, o ordinário, os detalhes da vida cotidiana (a realidade objetiva dos fatos sociais como um contínuo desenrolar das atividades do cotidiano). 
Algumas expressões-chave na abordagem etnometodológica utilizadas na investigação são aqui destacadas:

- Ação humana, que è a ação orientada por regras sociais e que pode ser interpretada;

- Atividades práticas cotidianas, que estão no centro dos interesses dos estudos etnometodológicos, o que significa aceitar cada membro da sociedade como um "teórico social prático" e dar atenção às suas ações como se dá aos eventos considerados extraordinários;

- Senso comum, entendido como formas de conhecimento mútuo partilhadas por membros de uma mesma cultura;

- Crenças estabelecidas, que são descrições do mundo social que, como produto organizado dos atos humanos, são a base deste mundo;

- Reflexividade como a auto-reflexão dos atores humanos sobre suas próprias condutas e a de terceiros. Reflexividade do observador social sobre as teorias que produz e as que são produzidas por outros atores sociais e cujo comportamento procura explicar.

Tomando o significado como conceito central da sua análise, a etnometodologia leva em consideração a vida cotidiana (everyday life) e as atividades rotineiras - suas práticas - detalhadas pelos atores sociais. Estas práticas, como práticas sociais, indicam que são os indivíduos que constroem a realidade social, ainda que sofram a orientação de contextos existentes. Tal perspectiva se mostrou fundamental na condução da investigação pretendida por permitir uma leitura não-estrutural da inovação na gestão em saúde. 
No entanto, há que reconhecer um dos limites da etnometodologia no que diz respeito à negação do poder, considerado como intrínseco ao intercâmbio social entre as pessoas (GIDDENS 1996, 1998), aspecto que busquei superar na análise

Inspirada em DE CERTEAU (1998), tentei entender os modos de proceder da criatividade cotidiana através da distinção das "(...) operações quase microbianas que proliferam no seio das estruturas tecnocráticas e alteram o seu funcionamento por uma multiplicidade de <táticas> articuladas sobre os <detalhes> do cotidiano" (p. 41). Ele afirma que na interpretação da cultura ordinária a ordem é, ao mesmo tempo, exercida e burlada, o que seria favorável não só para a interpretação das inovações na gestão como para entender sua produção. Nas determinaçōes institucionais, "se insinuam assim um estilo de trocas sociais, um estilo de invençöes técnicas e um estilo de resistência moral" (DE CERTEAU 1998, p. 20).

Aqui se destaca a concepção de tática utilizada por este autor, que parece pertinente para a compreensão do objeto de investigação proposto, isto $\dot{e}$, a possibilidade de existirem inovações na gestão num microespaço das organizações de saúde. Por tática, o autor compreende o cálculo que não possui uma fronteira que distinga o outro como uma totalidade visivel, dado que é um cálculo dentro do campo de visão deste outro, e num espaço por este controlado. Este cálculo é dependente do tempo e joga constantemente com os acontecimentos. A tática é determinada pela ausência de poder e, portanto, é considerada pelo autor como uma arte do fraco. Muitas das práticas cotidianas e das "maneiras de fazer" seriam do tipo táticas. As táticas permitem, então, tornar "mais forte" uma posição "mais fraca", burlando o poder através da capacidade de utilizar bem a ação em um determinado instante (DE CERTEAU 1998, pp. 45-48). Tal conceito de tática do cotidiano possibilita analisar as inovações como criadas a partir de fissuras causadas na organizaçāo e, por isto, com certa capacidade de subverter a lógica estruturada desta organização. 
O foco da investigação não foi a identificação de inovações institucionais em uma totalidade estruturante, mas a possibilidade de identificar diferentes inovações independente de sua possibilidade de generalização e, conseqüentemente, de disseminação e valorização positiva.

Por fim, mas não menos importante, inspirei-me em MORIN (1998), que defende que todo conhecimento seja ele filosófico, científico ou poético, emerge da vida cultural comum entre as pessoas. Propondo a idéia de estudar o acontecimento como uma não-regularidade e um fator desestruturador das relações instituídas, este autor assegura a existência de uma relação dialética entre quem observa e o que é observado. Também as idéias de LAPASSADE (1996) quanto ao estudo do microssocial serviram de referência sobretudo na utilização da etnometodologia como instrumento para compreender e interpretar as realizaçōes práticas dos atores/gestores da saúde e de outros instrumentos para o desenho metodológico do trabalho de campo.

Considerando que os atores/gestores são portadores de diferentes culturas, torna-se relevante uma breve discussão sobre este aspecto na investigação, buscando esclarecer de que maneira este conceito permeou o trabalho de campo e a análise. A compreensão das diversas culturas que são inerentes aos atores sociais permitirá, inclusive, romper com uma das criticas feitas a etnometodologia, quanto ao seu desconhecimento de o que condiciona ou determina a visão dos atores sociais (MINAYO 1993, pp. 51 55).

O conceito de cultura é dos mais discutidos e polêmicos nas ciências humanas. A importância do conceito de cultura foi destacada por GEERTZ (1995, p. 14), ao se referir à necessidade de limitá-lo adequadamente, considerando as múltiplas e diferentes definições existentes. Para este autor, a cultura seria uma teia (tecida pelos homens) de significados e das 
análises daí decorrentes, sendo também um contexto onde podem ser descritos com densidade (isto é, de forma inteligivel) os acontecimentos sociais, os comportamentos, as instituições e os processos.

A cultura também pode ser entendida como uma "forma de comunicação do individuo com o grupo e com o universo" (SANTOS 1996, pp. 261-262) gerada a partir das mudanças produzidas no lugar onde se vive, com o objetivo de dar continuidade à própria vida.

MORIN (1998, p. 23) relaciona a cultura, que é uma característica das sociedades humanas, como organizada/organizadora através da linguagem. Desse modo, todo conhecimento é produzido por uma cultura, mas com um potencial de autonomia relativa dada por "espíritos individuais". Isso porque "os indivíduos não são todos, e nem sempre, mesmo nas condições culturais mais fechadas, máquinas triviais obedecendo impecavelmente à ordem social e às injunções culturais" (MORIN 1998, p. 30). Para enfraquecer o que chama de imprinting cognitivo, ou seja, os paradigmas, doutrinas e estereótipos e a normalização social, o autor propõe que exista vida cultural e intelectual dialógica através do "calor" cultural e da expressão de desvios (MORIN 1998, p. 38). É na tentativa de expressão de inovações na gestão em saúde como desvios que desenvolvemos esta investigação.

As bases teóricas delineadas inserem a opção metodológica no campo da pesquisa qualitativa. Tal opção justifica-se pelo caráter do objeto a ser investigado.

Segundo PATTON (1990), a pesquisa qualitativa é extremamente apropriada ao estudo de processos, já que estes exigem descrições detalhadas, variam muito a depender dos atores envolvidos e são muito fluidos e dinâmicos. É apropriada também pelas características da pergunta inicial da investigação e pelo fato de não existir nenhum controle sobre os eventos que se queria estudar. Além disso, o estudo sobre inovações na 
gestão em saúde num espaço microlocalizado (o Distrito Sanitário Barra/Rio Vermelho) se constituia num fenômeno passivel de estar ocorrendo concomitante ao desenvolvimento da própria investigação (YIN 1994).

A pesquisa empírica foi operacionalizada no Distrito Sanitário Barra/Rio Vermelho, como já dito anteriormente. Para o desenvolvimento do trabalho de campo foram respeitados os seguintes passos (MORGAN 1993; YIN 1994):

1. Adentrar o campo buscando a maior quantidade de informação com a mínima influência possível do pesquisador e utilizando várias fontes na coleta de dados.

2. Agir como um aprendiz, sendo um observador e ouvinte atento do cotidiano, evitando ao máximo julgamento sobre o que observa e ouve.

3. Reconhecer o terreno, o que significa desenhar o cenário interno e externo da organizaçăo estudada.

4. Identificar situaçōes-chave do cotidiano produzidas pelos atores locais.

5. Analisar a própria experiência do pesquisador nesta situação.

6. Confirmar, refinar e reformular a análise realizada e compreender as explicaçöes através do que está atrás das palavras, conceitos $\theta$ imagens/metáforas utilizadas pelos sujeitos; permitindo que a situação e seu contexto "falem".

Ainda que exija uma boa capacidade de improvisação (BECKER 1997 , p. 14), a pesquisa qualitativa também requer o cumprimento de principios que assegurem o rigor do trabalho. Alguns deles são explicados a seguir. 
A pesquisa qualitativa não é passivel de ser replicada ou generalizada. Considerando a sua especificidade, o rigor a ser buscado está na própria explicitação dos critérios de escolhas dos participantes, do contexto da investigação e sua relação com os achados e dos passos da análise, segundo as recomendações de vários autores (MORGAN 1993; MORIN 1998; SPINK 1999).

Quanto à validação dos resultados e conclusões, esta, em estudos qualitativos, é sempre relativa. Isso porque todo o conhecimento gerado a partir da pesquisa está baseado em um contexto específico e não pode ter uma validação universal.

Não existindo a possibilidade de aplicar, na pesquisa qualitativa, a validação como é entendida na pesquisa quantitativa, também segui as recomendações sobre validação feitas por SARTORI (1997, pp. 194-195), que sublinha alguns princípios reguladores sobre os valores do observador/pesquisador, dado que não existe uma neutralidade possível. Desse modo, na análise procuro separar os juízos de fato dos juizos de valor e explicitar meus próprios valores implicitos e mais freqüentemente descrever o evento/fenômeno antes de atribuir valores. A atenção quanto à apresentação, com eqüidade, dos vários pontos de vista valorativos identificados também foi um critério utilizado.

Já PATTON (1990) refere-se ao fortalecimento da credibilidade de pesquisas e análises qualitativas através das técnicas e métodos utilizados; das bases teóricas assumidas na condução do estudo; e pelas próprias qualificações do pesquisador em termos de experiência e perspectivas. Tais cuidados foram levados em consideração no nosso estudo.

MORGAN (1993) propõe que os achados sejam verificados através das percepções e interpretações dos sujeitos que partilham uma perspectiva 
ou interesses comuns, e segundo suas indicações adotei os seguintes procedimentos:

a) registro de reações durante a coleta de informações;

b) checar com perguntas especificas um determinado achado;

c) aplicação de um "teste de ressonância" no processo da investigação:

- verificando os "ecos" (se negativos ou positivos) causados pela inovação identificada;

- verificando se as inovações se tornam "propriedade" dos atores (e de quais);

- qual a repercussão que as inovações causam sobre os atores locais e o trabalho.

Quanto à triangulação, recurso de validação em pesquisa qualitativa, foi utilizada de uma maneira não-tecnicista, visando contribuir no aprofundamento e na extensão da própria análise. Foi aplicada às técnicas de coleta de dados, às fontes e também à observação de eventos em espaços distintos e com a participação de distintos atores. Assim, foram fontes das informações analisadas gestores institucionais (ex-membros e atuais membros da coordenação do próprio distrito sanitário e gerentes de unidades de saúde); conselheiros locais de saúde (representantes da comunidade local e dos trabalhadores da saúde) e conselheiros municipais de saúde (com atividades mais próximas do distrito sanitário estudado); trabalhadores da saúde (de nível universitário, médio e técnico); usuários dos serviços, envolvendo moradores de quatro áreas de abrangência do total de nove existentes no distrito sanitário; membros da direção executiva do Projeto UNI/Bahia e do Fórum Comunitário de Combate à Violência. 
$\mathrm{Na}$ análise, procurei acentuar nos achados as diferenças, explicitando dados muitas vezes minuciosos e desagregados (SARTORI 1997, p. 216). Com todo esse processo, busquei explicitar, na análise e conclusões, não uma verdade única, mas sim as diferenças e semelhanças entre as concepções de diversos atores-gestores sobre uma dada realidade, não negando os conflitos e contradições existentes.

\subsubsection{Implicações éticas}

Para assegurar uma relação ética com os participantes, inicialmente foi realizada uma reunião com membros da coordenação do distrito sanitário, incluindo sua coordenadora, onde apresentei e esclareci todos os objetivos da investigação. Por solicitação da coordenação, encaminhei um documento à secretária municipal de saúde pedindo autorização para a realização da pesquisa e fornecendo os dados básicos sobre a mesma. Outros contatos pessoais foram feitos com técnicos do nivel central da Secretaria Municipal da Saúde, informando sobre o trabalho a ser realizado. $O$ recebimento formal da autorização solicitada levou quase dois meses.

Em todas as unidades de saúde em que fiz observações e com todos os participantes da pesquisa foi dada a conhecer a existência da autorização formal e da completa liberdade deles em participar ou não da investigação. No entanto, o consentimento informado, através da assinatura de um documento de aceitação em participar da investigação, sempre proposto, foi sempre recusado com argumentos de que "não se fazia necessário" ou de "conheço seu trabalho, sei que é sério" ou ainda, para os trabalhadores da saúde, "não é interessante assinar nada".

Nos contatos com lideranças locais este processo se repetiu e alguns deles se tornaram, durante toda a pesquisa, facilitadores do trabalho de campo. 
Em todos os contatos, atividades e eventos relacionados com a pesquisa, dediquei uma parte do tempo à discussão do estudo e objetivos e à garantia de anonimato aos participantes. Sempre existiram várias perguntas sobre a finalidade do trabalho, a importância para os participantes de atividades de investigação e a utilização dos resultados. Em alguns grupos focais realizados, após seu término, os participantes demonstravam interesse em discutir a pesquisa, ouvir a opiniāo da pesquisadora sobre os serviços de saúde e mesmo sobre a politica local.

Alguns atores convidados para atividades de grupo focal, ainda que não tenham se negado a participar, não compareceram. Várias vezes os convites (sempre por escrito, além de contatos pessoais e/ou telefônicos) foram refeitos, aceitos, mas mesmo assim algumas ausências foram registradas. Existiu dificuldade para contatar alguns gerentes de unidades de saúde, que terminaram não sendo incluidos na pesquisa. Apenas um membro de um dos conselhos locais de saúde e líder na sua comunidade, ainda no primeiro contato, recusou participar do grupo focal e que se realizasse qualquer atividade da pesquisa no que chamou de "minha área", afirmando estar cansada de "ser explorada pela universidade". No entanto, outros membros dessa mesma comunidade participaram da pesquisa voluntariamente.

\subsubsection{Lições aprendidas}

A dificuldade para encontrar referências exemplares do tratamento/apresentação de dados qualitativos exigiu não só um exaustivo levantamento bibliográfico como certa capacidade criativa da autora em apresentar os achados. As principais fontes de inspiração neste estudo foram os exemplos encontrados em SPINK (1999) em relação a modos de elaborar quadros e fluxos com dados qualitativos e de YIN (1994) quanto às tipologias gerais de análise qualitativa. 
Ao buscar um resultado final como um mosaico móvel (LÉVY 1999) de um retrato singular e ativo de inovaçōes na gestão em saúde, a metodologia adotada se mostrou eficaz, considerando que todo método tem sempre uma aparência que nos engana e que no processo de fazer é que se descobre qual o verdadeiro método utilizado. No entanto, um trabalho com tais caracteristicas se tornaria mais rico se pudesse contar com uma equipe de trabalho que permitisse a troca de informações e opiniōes durante o próprio processo.

Uma das dificuldades enfrentadas no trabalho de campo se constituiu na entrada. Primeiro, por existir algum grau de conhecimento com diversos atores locais devido a minha trajetória profissional em serviços de saúde. Isso me custou um relacionamento paradoxal. Alguns dos informantes da pesquisa me disseram "em off" muito mais do que seria ético utilizar num trabalho como este. No entanto, algumas das afirmações se mostraram coerentes com as observaçōes e com os depoimentos de outros atores, 0 que muito contribuiu na validação interna dos achados.

Também não posso ignorar o que se constituiu em uma forma de sofrimento quanto às constatações do meu próprio olhar sobre a realidade de saúde local e do sofrimento expressado pelos trabalhadores da saúde. Isto foi parcialmente expresso nas anotaçōes do diário de campo e compartilhado com outras pessoas durante o processo. $O$ fato de que a análise final dos achados tenha sido iniciada oito meses após o trabalho de campo me restituiu o distanciamento crítico necessário para separar as descriçōes, interpretaçōes, julgamentos, conclusões e recomendaçōes que, espero, estejam explicitadas em seus devidos lugares. 


\subsection{Técnicas utilizadas}

Para levantar os dados na pesquisa utilizei desde a análise documental atual e retrospectiva (principalmente relatórios de gestão e documentos técnico-políticos produzidos pela Secretaria Municipal da Saúde e pelo distrito sanitário e atas do Conselho Municipal de Saúde no periodo de janeiro de 1997 a novembro de 1999). Também utilizei a observação de eventos com anotações; grupo focal e entrevistas profundas e semiestruturadas, além do registro diário do trabalho de campo com duas vertentes distintas: registros de caráter metodológico e registros sobre eventos, processos e relações observados. Tais procedimentos são detalhados a seguir e para facilitar a compreensão (intrincada) do "enredo analitico" apresento um quadro sintético relacionando procedimentos utilizados e atores locais envolvidos. 
Quadro 1 - Relação entre procedimentos utilizados no trabalho de campo e atores locais envolvidos (como informantes e autores de documentos)

\begin{tabular}{|c|c|c|c|c|c|c|}
\hline Procedimento & $\begin{array}{l}\text { Momento } \\
\text { exploratório }\end{array}$ & Entrevista & Grupo focal & Observação & $\begin{array}{ll}\text { Diário de } \\
\text { campo }\end{array}$ & $\begin{array}{l}\text { Análise } \\
\text { documental }\end{array}$ \\
\hline Membros do Projeto UNI/BA & & & & & & \\
\hline Membros da coordenação do DSBRV & & & & & & \\
\hline Ex-coordenadora do DSBRV & & & & & & \\
\hline Trabalhadores da saúde & & & & & & \\
\hline Membros do Conselho Municipal de Saúde & & & & & & \\
\hline Membros dos Conselhos Locais de Saúde & & & & & & \\
\hline Usuários dos serviços de saúde & & & & & & \\
\hline Membro do FCCV & & & & & & \\
\hline Agentes Comunitários de Saúde & & & & & & \\
\hline Outros profissionais & & & & & & \\
\hline
\end{tabular}




\subsubsection{Procedimento 1: momento exploratório}

Para a reinserção no espaço do distrito sanitário, comecei com um mapeamento da situação local. Este foi feito através de uma discussão coletiva com pessoas que, pelas posições privilegiadas que ocupavam, possuiam um grande número de informações sobre o local. Esta discussão foi realizada sem roteiro prévio. Posteriormente complementamos as informaçōes iniciais realizando entrevistas profundas $(N=3)$ com participantes da discussão inicial.

Esta fase de mapeamento foi complementada através de contatos com pessoas atuantes na área e durante a participação de eventos diversos para os quais era convidada ou demonstrava interesse em participar. Tais contatos me permitiram uma inserção relativamente fácil no distrito, incluindo contatos importantes com moradores locais cuja participação na pesquisa se revelou fundamental.

As informaçōes obtidas me permitiram não só reconhecer o terreno, do qual estava afastada havia um ano e meio, como esboçar um primeiro cenário interno e externo ao distrito, bem como identificar pistas para as situaçōes-chave do cotidiano que se revelavam importantes para o tema da pesquisa.

\subsubsection{Procedimento 2: entrevistas}

As entrevistas semi-estruturadas com membros da coordenação do distrito sanitário $(N=5)$; ex-membro da mesma coordenação $(N=1)$; gerentes de unidades de saúde $(\mathrm{N}=4)$; e conselheiros municipais de saúde $(\mathrm{N}=2)$ foram um modo importante para coletar informaçōes. 
A escolha dos entrevistados se pautou por critérios diversos:

- Para os membros da coordenação do distrito sanitário, entrevistei todos com pelo menos mais de um ano de trabalho na função, dado que existiu uma grande rotatividade entre os técnicos na coordenação.

- Os gerente de unidades de saúde foram escolhidos pelas pistas fornecidas durante o momento exploratório relacionadas com o melhor ou pior funcionamento dos serviços ou destaque na postura dos gerentes (negativos e positivos).

- Os conselheiros municipais de saúde foram escolhidos por terem uma relação estreita com o distrito sanitário estudado, sendo portadores de informações privilegiadas e tendo um papel no acompanhamento dos conselhos locais de saúde da área.

As entrevistas foram gravadas (com duração que variou entre trinta e cinco minutos a duas horas) e transcritas com a colaboração de terceiros, sendo todas revisadas pela autora (Anexo 1). Apenas dois dos entrevistados não concordaram com a gravação das entrevistas, o que me obrigou a fazer anotações pontuais com alguns registros literais. Não existiu recusa quanto a ser entrevistado e apenas não me foi possivel manter contato com dois dos informantes identificados no processo.

Durante as entrevistas procurei interferir o mínimo possivel, e as poucas questōes levantadas foram motivadas ao longo dos depoimentos. Todas as entrevistas iniciavam com a solicitação de que o entrevistado descrevesse e comentasse as suas atividades cotidianas no desenvolvimento das atividades de interesse para a investigação. 


\subsubsection{Procedimento 3: grupos focais}

Os grupos focais ${ }^{6}$ foram realizados com conselheiros locais de saúde representantes da comunidade $(\mathrm{N}=2)$; conselheiros locais de saúde representantes dos trabalhadores da saúde $(\mathrm{N}=2)$; trabalhadores da saúde $(\mathrm{N}=3)$; usuários dos serviços locais de saúde $(\mathrm{N}=3)$. Todos os grupos focais foram gravados e transcritos exaustivamente e além de contar com uma facilitadora da discussão (sempre a pesquisadora) tinham um ou dois observadores que tomavam notas de outros aspectos de interesse (Anexos 2 e 3).

A seleção dos participantes foi baseada:

- No caso dos conselheiros representantes da comunidade, através das informaçōes coletadas no momento exploratório, buscando identificar os conselheiros com atuação destacada. Foram convidados membros de todos os conselhos existentes, mas nem todos atenderam ao convite. Os convites foram feitos pela pesquisadora, por escrito, e em alguns poucos casos por telefone. Dias antes da realização dos grupos focais era feita uma confirmação telefônica da presença dos convidados. Em média houve $20 \%$ de ausência por grupo.

- No caso dos conselheiros representantes dos trabalhadores da saúde, foram convidados aqueles com atuação mais destacada em quatro áreas de abrangência do distrito sanitário. Nesse grupo as ausências foram mais freqüentes, sendo que um dos grupos teve que ser remarcado por não apresentar quórum suficiente na primeira reuniāo.

\footnotetext{
6 A organizaçăo e o desenvolvimento dos grupos focais foram baseados em dois documentos: Krueger RA. Focus Group. A Practical Guide for Applied Research. $2^{\text {nd }} \mathrm{ed}$. Thousand Oaks: Sage Publications; 1994 e Dawson S, Manderson L and Tallo VL. Social and Economic Research. The Focus Group Manual. Switzerland: World Health Organization; 1992.
} 
- No caso dos trabalhadores da saúde, os grupos foram desenvolvidos no próprio local de trabalho nas duas áreas de abrangência onde realizei a observação nos serviços de saúde. Os grupos tinham representantes de várias categorias profissionais (o convite foi feito a pessoas com funçōes distintas no serviço). Um deles contou apenas com profissionais de nível universitário e o segundo com profissionais de nivel universitário e médio.

- No caso dos usuários, o convite foi feito por lideranças locais e o critério foi o de ser morador da área há pelo menos dois anos e utilizar o serviço público de saúde local. Dois dos grupos foram realizados em equipamentos da própria comunidade o que facilitou muito a presença dos moradores e o terceiro em instalação da universidade.

\subsubsection{Procedimento 4: observação e diário de campo}

A observação direta foi realizada em dois centros de saúde, durante um periodo de dois meses em cada um. Nas unidades de saúde, quase sempre tomei como referência determinados postos de trabalho, o que facilitava uma visão estratégica sobre os acontecimentos em geral, ainda que com o cuidado de não estabelecer relações exclusivas. Isso permitiu maior flexibilidade para buscar as situaçōes observadas, dado que não pretendia observar apenas práticas e situaçōes rotineiras. $O$ fato de adotar posiçōes diferentes durante a observação também se mostrou muito útil e eliminou a possibilidade de existir algum constrangimento dos observados.

Por exemplo, nos serviços de saúde, assumi atividades em que buscava auxiliar no trabalho desenvolvido no local ou atender a solicitaçōes.

As observações de eventos se desenvolviam de modo pontual, a depender do acontecimento. Os eventos de interesse foram sendo selecionados no processo e baseados nas informações surgidas durante o 
momento exploratório inicial e nas entrevistas e grupos focais. Durante o processo, busquei adotar posiçōes diversas para que pudesse observar situaçōes variadas e me adaptar ao ritmo dos acontecimentos. Só intervinha (o que acontecia raramente) quando solicitada diretamente. Durante eventos do tipo reunião, algumas vezes me foi solicitada ajuda para registro de atas ou para colaboração em algumas atividades posteriores.

Basicamente foram observadas atitudes e expressōes do meio estudado e ações e pontos de vista dos participantes. As anotaçōes dos eventos observados eram feitas durante a observação e complementadas posteriormente. Tais anotaçōes foram separadas em duas categorias; anotações de caráter metodológico e descrição/definição da situação (PERETZ 1998). Esta separação se mostrou útil não apenas para identificar problemas na condução do próprio trabalho de campo como também nos ajustes dos objetivos definidos da investigação e no desenho da análise definida no projeto de pesquisa.

\subsubsection{Procedimento 5: leitura e análise de documentos oficiais}

Ainda que tenha buscado coletar e ler alguns documentos institucionais produzidos no próprio distrito sanitário, estes se mostraram quase inexistentes ou de qualidade de conteúdo inadequado para as finalidades da investigação. Mesmo assim, na descrição e na análise utilizei algumas informaçōes obtidas nestas fontes.

A leitura das atas do Conselho Municipal de Saúde não se mostrou útil para a análise de aspectos específicos da gestão do distrito sanitário estudado, mas foi útil na análise relativa à gestāo e condução política da própria Secretaria Municipal da Saúde. 


\subsection{Desenho da análise}

O desenvolvimento da análise articulou a macro e a microanálise do contexto interno e externo ao espaço estudado, o Distrito Sanitário Barra/Rio Vermelho, de modo a relacioná-las e complementá-las ainda que mantidas separadas. A articulação entre a produção da vida social com a reprodução social foi considerada com os limites reconhecidos por GIDDENS (1996, p. 145). Para ele, embora se reconheça, nas escolas da sociologia, que a produção da sociedade é uma realização dos seus membros, este pressuposto ainda não está conciliado com a noção de que os seres humanos que fazem a sociedade não o fazem sob condições de sua própria escolha.

Enquanto um estudo exploratório e indutivo, a tônica da análise foi a busca da possibilidade e significância de inovações no processo de gestão, tomando em conta a realidade onde está inserido o distrito sanitário. As inovações foram selecionadas e analisadas segundo a relevância com que foram enunciadas pelos atores locais e consideradas como casos atipicos.

O grande desafio foi conduzir a análise dos achados de modo a ir além da aparência do fenômeno e do seu significado, perpassando o conteúdo das práticas reais dos atores relevantes para a investigação, de modo a captar as inovações reconhecidas.

Isto significa que, dentro das limitações e simplificaçōes do objeto que inevitavelmente ocorreram no processo, interpretei os procedimentos identificados como inovadores, relacionando-os com os documentos, atos de fala e discursos oficiais, criando categorias que surgiram a partir dos achados. 
Inicialmente a análise foi desenhada em quatro planos, relacionados com os objetivos especificos:

- Plano de análise do contexto interno e externo da organização, através dos conteúdos dos textos dos documentos consultados; das falas dos entrevistados e dos grupos focais; da identificação de transformações produzidas na gestão.

- Plano de análise das inter-relaçōes, contemplando as relaçōes entre os gerentes e a equipe técnica, membros dos conselhos de saúde e usuários dos serviços. Isto será desenvolvido através da análise do conteúdo das falas e argumentos dos participantes das entrevistas e grupos focais; a rotina de um dia de trabalho; o tom das conversas e discussões; as sutilezas refletidas no comportamento das pessoas observadas e de suas ações cotidianas (expressões; atitudes; humor).

- Plano de análise das situações em que são criados os processos e técnicas inovadoras de gestão.

- Plano de análise dos resultados percebidos, em que seriam analisados os resultados percebidos pelos diversos sujeitos quanto ao grau de institucionalização da inovação na gestão, a expectativa quanto a adoção ou não da inovação identificada, ganhos institucionais ou individuais percebidos e efeitos positivos e negativos da inovação.

Além de muito amplos e ambiciosos (ver Anexo 4), tais planos foram revistos antes do trabalho de campo, como resultado de diversas discussōes sobre o projeto original e adequação às condições objetivas da investigação.

Posteriormente, na pré-análise dos achados, realizada com a utilização de software especifico para dados qualitativos, uma nova revisão 
dos planos de análise a partir da construção da árvore de nós críticos de categorias de análise possiveis resultou no produto final de dois planos:

\section{Plano de análise do contexto interno e externo:}

Análise do contexto interno e externo da organização, através dos conteúdos dos documentos consultados e dos achados nas entrevistas e grupos focais.

\section{Plano de análise das situações:}

Identificação e análise das inovações e suas caracteristicas, bem como das repercussões percebidas pelos diversos atores e da avaliação enunciada.

Foram incluidas também as relações entre os gerentes e a equipe técnica, membros dos conselhos de saúde e usuários dos serviços. Isto foi desenvolvido através da análise do conteúdo das falas e argumentos dos participantes das entrevistas e grupos focais; da observação do cotidiano do trabalho e dos eventos, principalmente quanto ao tom das conversas e discussōes; das sutilezas refletidas no comportamento das pessoas observadas e de suas ações cotidianas (expressões; atitudes; humor).

Com base nos planos foi feita uma leitura transversal em todo o material coletado nas entrevistas e grupo focais (trezentas laudas) e das anotações de campo (quarenta laudas).

A partir do material coletado nas entrevistas e grupos focais foi feita uma primeira categorização com base nos objetivos e questões motivadoras. Posteriormente, na pré-análise dos achados com apoio do software Q.S.R. NUD.IST4 (QUALITATIVE SOLUTIONS AND RESEARCH PTY LTD. 1997) as categorias sofreram vários reajustes. 
Os achados foram então processados por categoria e por unidade de análise (no caso, as unidades de texto correspondiam a um ou mais parágrafos, de modo a abranger toda a idéia expressa no contexto), construindo uma árvore cujos troncos e nós correspondiam a categorias e sub-categorias. Os nós foram compostos pelo conteúdo das unidades de análise. A lista de nós resultante da análise preliminar dos achados pode ser apreciada no Anexo 5. Em seguida apresento a Figura $1 \mathrm{com}$ a lista final de nós e sub-nós utilizadas na análise, resultante da sintese feita a partir da análise preliminar dos achados. Na Figura 2 apresento o desenho gráfico da árvore. As esferas numeradas com 1 e 2 representam os planos de análise finais: 1. Plano de análise do contexto e 2. Plano de análise das situaçōes.

O Plano 1 se desdobra em três ramos: (1) Governo e política local (com sub-ramos com conteúdos relativos à Secretaria Municipal; Municipalização e Perspectivas); (2) Cotidiano (com sub-ramos relacionados com Problemas; Táticas; Relaçōes e Enunciaçōes Avaliativas) e (3) Gestāo do DSBRV (com sub-ramos sobre Decisão; Perfil do Gestor; Análise da Gestão; Relações e Enunciações Avaliativas).

O Plano 2 tem como único ramo as Inovações na Gestão (1), que, por sua vez se desdobra em Definição de Inovação (1) e Identificação das Inovações na Gestão (2). Este, por fim se subdivide em quatro, que são as inovações identificadas e posteriormente analisadas. 
Figura 1. Lista final de nós adotada como guia para análise dos achados

Q.S.R. NUD.IST Power version, revision 4.0.

\section{(1) Plano de análise do contexto interno e externo}

(1 1) Plano de análise do contexto interno e externo/Cotidiano

(111) Plano de análise do contexto interno e externo/Cotidiano/Problemas

(1 1 2) Plano de análise do contexto interno e externo/Cotidiano/Táticas

(113) Plano de análise do contexto interno e externo/Cotidiano/Enunciação avaliativa

(1 14) Plano de análise do contexto interno e externo/Cotidiano/Perspectivas

(1 2) Plano de análise do contexto interno e extemo/Política local

(1 2 1) Plano de análise do contexto interno e extemo/Política local/Governo municipal

(1 2 2) Plano de análise do contexto interno e externo/Politica local/Municipalização

(1 2 3) Plano de análise do contexto interno e extemo/Política local/Conselho Municipal de Saúde

(1 2 4) Plano de análise do contexto interno e externo/Política local/SMS

(1 2 5) Plano de análise do contexto interno e externo/Politica local/DSBRV

(1 2 6) Plano de análise do contexto interno e externo/Politica local/Universidade

(1 2 7) Plano de análise do contexto interno e externo/Politica local/Mídia

(1 2 8) Plano de análise do contexto interno e externo/Política local/Perspectivas

(1 2 9) Plano de análise do contexto intemo e externo/Politica local/Política

(1 3) Plano de análise do contexto interno e externo/Gestão do DSBRV

(1 3 1) Plano de análise do contexto interno e externo/Gestão do DSBRV/Modelo de gestão

(1 3 1 1) Plano de análise do contexto intemo e extemo/Gestão do DSBRV/Modelo de gestão/Acesso

(1 3 1 2) Plano de análise do contexto intemo e externo/Gestão do DSBRV/Modelo de gestão/Acesso/Informação

(1 3 1 13 ) Plano de análise do contexto intemo e externo/Gestão do DSBRV/Modelo de gestão/Serviços de Saúde

(1 3 1 4) Plano de análise do contexto intemo e externo/Gestão do DSBRV/Modelo de gestão/Decisão, participação e acesso

(1 3 2) Plano de análise do contexto interno e externo/Gestão do DSBRV/Perfil do gestor

(1 3 3) Plano de análise do contexto interno e externo/Gestão do

DSBRV/Gestor/Identificação

(1 3 4) Plano de análise do contexto interno e externo/Gestão do

DSBRV/Enunciação avaliativa

(1 3 5) Plano de análise do contexto interno e externo/Gestão do

DSBRV/Perspectivas

\section{(2) Plano de análise das situações}

(2 1) Plano de análise das situações/Inovação

(2 1 1) Plano de análise das situações/Inovação/Definição

(2 1 2) Plano de análise das situações/Inovação/Exemplos

(2 12 2 1) Plano de análise das situações/Inovação/Exemplos/CLS

(2 121 1) Plano de análise das situações/Inovação/Exemplos/CLS/Características 
Figura 1. Lista final de nós adotada como guia para análise dos achados, continuação.

(2 121212 ) Plano de análise das situações/Inovação/Exemplos/CLS/Concepção sobre o papel

(2 12 1 13 ) Plano de análise das situações/Inovação/Exemplos/CLS/Perfil conselheiros

(21214) Plano de análise das situações/Inovação/Exemplos/CLS/Ação e táticas (2 1214 1) Plano de análise das situaçōes/Inovação/Exemplos/CLS/Ação e táticas/Barreiras

(2 121214 2) Plano de análise das situaçōes/Inovação/Exemplos/CLS/Ação e táticas/Facilitadores

(2 $12 \begin{array}{ll}2 & 15\end{array}$ ) Plano de análise das situações/nnovação/Exemplos/CLS/Enunciação avaliativa

(2 1216 ) Plano de análise das situações/Inovação/Exemplos/CLS/Repercussões

(2 $\left.1 \begin{array}{lll}2 & 2 & 2\end{array}\right)$ Plano de análise das situaçōes/Inovação/Exemplos/PACS

(2 1222 1) Plano de análise das

situaçōes/Inovação/Exemplos/PACS/Características locais

(2 $\left.\begin{array}{llll}2 & 2 & 2 & 2\end{array}\right)$ Plano de análise das situaçōes/Inovaçāo/Exemplos/PACS/Trabalho ACS

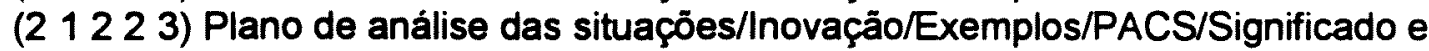
uso estratégico

(2 1222 4) Plano de análise das situações/Inovação/Exemplos/PACS/Enunciação avaliativa

(2 $12 \begin{array}{lll}2 & 2\end{array}$ ) Plano de análise das situações/Inovação/Exemplos/PACS/Repercussōes

(2 1223 ) Plano de análise das situaçōes/Inovação/Exemplos/Projeto UNI

(2 $\left.12 \begin{array}{lll}2 & 3 & 1\end{array}\right)$ Plano de análise das situaçōes/Inovação/Exemplos/Projeto UNI/Caracteristicas

(2 $12 \begin{array}{lll}2 & 3\end{array}$ 2) Plano de análise das situações/Inovação/Exemplos/Projeto UNI/Influência

(2 12 2 3 3) Plano de análise das situações/Inovação/Exemplos/Projeto UNI/Enunciaçāo avaliativa

(2 12234 ) Plano de análise das situações/Inovação/Exemplos/Projeto UNI/Repercussões

(2 12 4) Plano de análise das situações/Inovação/Exemplos/Trabalhando com a violência

(212 12 1) Plano de análise das situações/Inovação/Exemplos/Trabalhando com a violência/Violência: um problema de saúde

(2124 2) Plano de análise das situaçōes/Inovação/Exemplos/Trabalhando com a violência/Fórum Comunitário de Combate à Violência

(2 124 3) Plano de análise das situações/Inovação/Exemplos/Trabalhando com a violência/Enunciação avaliativa

(2 12 2 4 4) Plano de análise das situações/Inovação/Exemplos/Trabalhando com a violência/Repercussões

(2 12244 1) Plano de análise das situações/Inovação/Exemplos/Trabalhando com a violência/Repercussões/Nas pessoas

(2 12244 2) Plano de análise das situações/Inovação/Exemplos/Trabalhando com a violència/Repercussōes/Entre as pessoas

(2 12244 3) Plano de análise das situações/Inovação/Exemplos/Trabalhando com a violência/Repercussões/Na maneira de ver a realidade 
Figura 2. Árvore de categorias de análise.

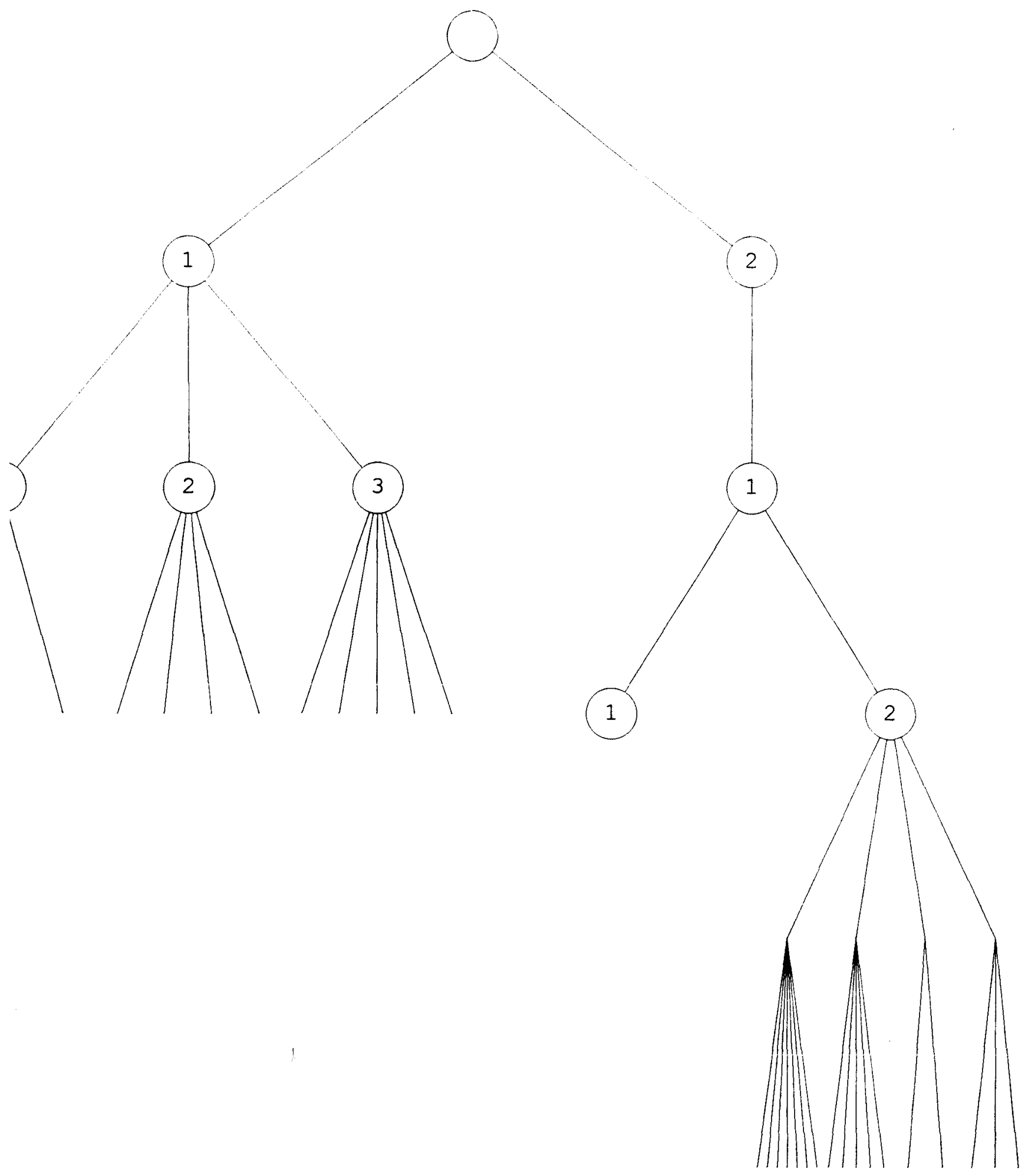


A análise foi desenvolvida com base em uma estratégia geral apoiada nas proposiçōes teóricas e nos planos de análise.

As técnicas e métodos utilizados têm como base a análise de conteúdo, principalmente as técnicas de análise temática, de enunciação e de avaliação (BARDIN 1977; DE CERTEAU 1998; KRIPPENDORFF 1985; MINAYO 1993). No entanto nenhuma dessas técnicas foi adotada exaustivamente e, ao contrário, foram adaptadas ao objeto e objetivos do estudo. Algumas reflexões valiosas para a adoção de um caminho próprio foram obtidas da leitura de GOODWIN and DURANTI (1997, pp. 1-42).

Para BARDIN (1977) a análise de conteúdo possui um conjunto de instrumentos e técnicas aplicados a discursos diversificados, buscando analisar a comunicação. Deste conjunto de técnicas, a análise de enunciaçāo propōe analisar a comunicaçāo como um processo, através da busca de elementos não-formais e estruturais deste. Aplica-se esta técnica visando apreender os diversos niveis envolvidos no discurso: condiçōes de produção da palavra; sentido das opiniões e atitudes no discurso; o estilo do discurso; os elementos atipicos do discurso (recorrências, importância; ambivalência; negaçāo; lapsos, lugares-comuns, etc.) (BARDIN 1977, pp. 169-184).

A técnica da análise temática contribuiu para a organização e categorização, na pré-análise do material, permitindo especialmente a identificação e seleção das unidades de análise.

Da análise da enunciação, utilizei a análise lógica das declaraçōes, permitindo inferir algumas relaçōes entre elas e identificar alguns elementos atipicos das falas, o que possibilitou dar relevância e consistência às inferências. 
Já a análise de avaliação considera que o conteúdo do discurso representa as atitudes de quem fala em relação ao objeto sobre o qual ele fala. Conseqüentemente busca identificar os juizos de valor expressos no discurso, através exclusivamente das atitudes (identificando objetos sobre os quais recai uma avaliação e termos avaliativos que são submetidos a uma nota) (BARDIN 1977, p.165-168). Assim este tipo de análise permitiu a identificação de enunciações avaliativas sobre todas as inovaçōes identificadas e ajudou a destacar aspectos relevantes quanto à análise crítica perpetrada pelos atores locais. Os resultados da avaliação foram referidos ao desempenho e qualidade dos objetos da atitude avaliativa dos atores. A construção de um balanço final permitiu ressaltar contradições e relevâncias dos aspectos avaliados. 


\section{O CONTEXTO EXTERNO AO MUNICÍPIO DE SALVADOR}

\subsection{A reforma do aparelho de estado no Brasil}

Desde os anos 80 , muitos paises em desenvolvimento, dentre os quais o Brasil, têm experimentado uma crise econômica com conseqüentes repercussões e efeitos negativos sobre os sistemas nacionais de saúde. $\dot{E}$ consenso que a partir desta mesma década agudiza-se a crise de estado no Brasil e em toda a América Latina. Há também o reconhecimento de que uma das conseqüências principais desta crise foi o descrédito quanto à capacidade de governo frente aos graves problemas econômicos e sociais.

No âmbito internacional, as medidas de enfrentamento da crise de estado, principalmente do estado de bem-estar social adotado nos paises ditos desenvolvidos, passa pela opção entre dois modelos para o reordenamento deste: adoção de um modelo social-democrata ou de um modelo neoliberal que defende a redução do estado (estado mínimo) e o mercado como diretivo destas reformas.

As caracteristicas da crise do estado brasileiro, segundo BRESSERPEREIRA (1995, 1996), seriam: uma crise fiscal crescente; exaustão de formas protecionistas de intervenção na economia e um aparelho de estado arcaico e ineficiente. A saída proposta para o governo de FHC passaria pelo que ele chama de construção de um estado social-liberal, responsável pelos direitos básicos de saúde e educação, por exemplo, ainda que executadas por intermédio de instituiçōes públicas não-estatais. Para este autor a adoção de tais medidas pelo governo não o caracterizaria como um governo neoliberal e sim social-liberal.

Em geral, no que diz respeito ao enfrentamento da crise do sistema de saúde, o governo FHC tem introduzido medidas tradicionais de quase- 
mercado $^{7}$, ainda que adotando como diretriz fundamental apenas a eficiência econômica. Para ser moderno o discurso oficial fala de mudanças para uma maior flexibilidade da gestão, orientação à clientela, qualidade dos serviços e privatização. No entanto, a discussão sobre a responsabilização sobre a saúde de milhōes de brasileiros que utilizam o SUS assim como a definição do que se considera como mercado estão ausentes dos documentos oficiais.

Sem pretender um aprofundamento da questão, vale referir a discussão feita a este respeito por ROBINSON (2001). Para este autor as pesquisas sobre análise econômica de serviços de saúde são desenvolvidas numa perspectiva micro e consideram tanto o conceito de mercado quanto o de organização como já estabelecidos. Dentre os elementos que devem ser considerados nas investigações sobre o mercado em saúde o autor propōe:

- que se estabeleça a clara distinção entre mercado e organizaçōes, dado que a estrutura do mercado não é determinada de modo exógeno e guarda estreita relação com a estrutura e o comportamento das organizações;

- uma reversão na tendência das investigaçōes sobre serviços de saúde em dirigir seu foco para a competição entre provedores de serviços similares e em mercados classificados como horizontais (isto é, mercados em que empresas oferecem serviços e bens similares para um mesmo grupo de potenciais consumidores);

\footnotetext{
${ }^{7}$ Uma discussão e conceituação interessante sobre o chamado quase-mercado de serviços sociais, entre eles o de saúde, pode ser encontrada em Gori C. Servizi Sociali e Mercato: La Riforma della Gran Bretagna. II Nuovo Govemo Locale, 1998; 1: 103-123. Neste artigo o autor define o mercado de serviços sociais como um quase-mercado ou mercado intemo, cabendo ao setor público a aquisiçăo de serviços de entes diferentes em concorréncia entre eles. A aquisição de serviços deve ser baseada nas necessidades de saúde dos grupos de populaçăo de acordo com a disponibilidade de recursos, avaliando-se ao longo do tempo os efeitos de tais serviços nos usuários.
} 
- aprimorar os estudos empíricos através da adoção de quadros de referência mais ricos e bem desenvolvidos, o que inclui a adoção de modelos conceituais oriundos de estudos sobre custos econômicos ao lado de outras subespecialidades das ciências sociais.

Percebe-se que as idéias acima têm como base os estudos desenvolvidos em hospitais, o que contribui para restringir as conclusões e usos que podem ser feitos para a realidade brasileira.

No entanto, a discussão conceitual e os estudos relacionados com o que se chama de quase-mercado podem trazer uma contribuição que atenda aos interesses de implementação do SUS. Vale ressaltar que também se faz imprescindivel estabelecer açōes relacionadas com a definição de niveis essenciais de assistência, de programação da oferta, de regulação de funções de médicos e de outros profissionais e serviços produtores ao interior do sistema, o que está ainda distante da realidade nacional. ${ }^{8}$

Algumas politicas direcionadas para a reforma do aparelho de estado estão delineadas no documento da Presidência da República intitulado "Plano Diretor da Reforma do Aparelho do Estado" (BRASIL 1995, 1997). Esta proposta governamental direciona-se para uma opção pelo mercado como modelo de excelência na prestação de bens e serviços, e para o "(...) fortalecimento do Estado para que seja eficaz sua ação reguladora, no quadro de uma economia de mercado (...) (BRASIL 1995, p. 9), sem explicitar como este modelo pode garantir a universalidade de acesso, a eqüidade assistencial e o controle social no sistema nacional de saúde.

\footnotetext{
${ }^{8}$ Sobre o conceito de niveis essenciais de assistência (core benefit, basic package, decent minimum ou cesta básica) existe uma vasta literatura intemacional. Pela atualidade da reflexão indico Fiorentini G. I servizi sanitari in Italia-2000. Milano: Società Editrice II Mulino; 2000, principalmente o Capitulo 1.
} 
A proposta governamental reconhece a necessidade de ajuste fiscal, reformas econômicas orientadas para o mercado, reforma da previdência social e inovação nos instrumentos de politica social. No entanto, a ênfase é dada à reforma do aparelho de estado, reconhecendo que esta não esgota a reforma de estado que o atual governo alardeia.

A reforma do aparelho de estado proposta (BRASIL 1995) é inspirada no modelo da administração pública gerencial, centrada no controle dos resultados e originada nas açōes tipicamente de mercado. A justificativa mais recorrente da escolha do modelo gerencial seria a sua capacidade de permitir a liberdade e agilidade necessárias para quem deve competir no mercado por resultados definidos previamente. Tal modelo, no entanto, já existe no país em relaçăo a empresas estatais e fundaçōes relacionadas com a área econômica desde os anos 50 (TEIXEIRA 1997).

O documento governamental enfatiza que a reforma do seu aparelho é fundamental para o alcance da capacidade de governo (ou governança), visando à implementação eficiente de políticas públicas. Estabelece também a definição de quatro setores do aparelho de estado brasileiro: 1) o núcleo estratégico, incluidos os Poderes Executivo, Legislativo, Judiciário e o Ministério Público; 2) as atividades exclusivas, setores em que somente o estado pode atuar; 3) os serviços não exclusivos, em que o estado atua juntamente com outras organizaçōes públicas não-estatais e privadas, onde se inclui o setor saúde; e 4) o núcleo de produção de bens e serviços para o mercado.

Nesta proposta, destacam-se duas vertentes básicas: a transferência para o setor privado das atividades que podem ser controladas pelo mercado (privatização), e a descentralização para o setor público não estatal da execução de serviços que não envolvam o exercício do poder de estado, "publicização", como é o caso da prestação de serviços de saúde. 
Para o setor saúde, interessam as medidas tomadas quanto à implantação das Organizaçōes Sociais/OS. Nesse sentido foi promulgada a Lei N. 9.637, de 15/5/98, que as institui. As OS são figuras jurídicas de direito privado, em nada diferente das tradicionais (MODESTO 1996; MELO e col. 1998). São adotadas como modelo de reforma para a administração da saúde (e de outros setores sociais), para onde serão transferidos serviços de saúde até então sob responsabilidade do estado. Deste modo o estado seria substituido na execução e prestação de serviços por este "setor público não-estatal", criado, mantido e fomentado pelo próprio estado.

Para sustentar tal proposta já existem instrumentos legais em alguns estados, a exemplo da Bahia e de São Paulo, que definem os elementos para a instituição e qualificação de entidades privadas sem fins lucrativos como organizaçōes sociais (BAHIA 1997; SÃO PAULO 1998). Além destes, os estados do Pará, Tocantins, Rio de Janeiro e Roraima e o Municipio de São Paulo já possuem instrumentos legais instituindo estes "novos" modelos de gestão pública da saúde.

O contexto macropolitico das reformas de governo e da administração pública no Brasil não tem considerado o processo de descentralização na saúde (municipalização). As medidas adotadas revelam uma mudança da estrutura da administração pública, com ênfase na desresponsabilização do estado frente às políticas públicas, como as políticas de saúde. OLIVEIRA (1998, p. 17), ao criticar a redução, pelo govemo, dos problemas da sociedade brasileira como meros problemas de administração, afirma que "é a sociedade civil, no pensamento do ministro Bresser-Pereira, administrando-se a si própria, o novo modelo do estado enxuto do século XXI. Bem reparada, tal reforma não passa de uma perigosa farsa: em primeiro lugar, os recursos continuam sendo públicos (...); em segundo lugar, não há nenhuma sociedade civil autogerindo-se: trata-se dos mesmos funcionários, cientistas e auxiliares, que estão na administração dessa nova 
entidade da sociedade civil. (...) A tecnologização da politica, que aparece sob as formas de sua <administrabilização>, é um dos traços mais perigosos do totalitarismo".

Dentre as críticas dirigidas ao governo Fernando Henrique Cardoso, contrapondo-se às propostas desenvolvidas para a reforma do estado brasileiro, OLIVEIRA (1998) destaca o fato de que, neste governo, a politica foi transformada em marketing. Esta transformação se dá com a mistificação de indicadores, além da construção de um governo com "personalidade autoritária", que reforça a segmentação e a acomodação da sociedade civil. Deste modo, o governo teria um forte aspecto institucional, através do controle e submissão dos demais poderes ao Poder Executivo. Os problemas da sociedade brasileira, na perspectiva oficial, estariam reduzidos como carências e não como direitos sociais, que são negociados e obtidos pela luta dos dominados.

Um exemplo que pode servir como elemento ilustrativo das afirmações anteriores é o número extensivo de medidas provisórias ${ }^{9}$ emitidas pelo governo federal:

\footnotetext{
${ }^{9}$ Vale lembrar que em outubro de 2001 o Congresso Nacional finalmente aprovou medida impeditiva do uso abusivo de medidas provisórias pelo poder executivo.
} 
Medidas Provisórias por Governo, Brasil, 1990-1998.

\begin{tabular}{l|c|c}
\hline \multicolumn{1}{c|}{ Governos } & $\begin{array}{c}\text { Collor } \\
\text { (1990-1992) }\end{array}$ & $\begin{array}{c}\text { FHC } \\
\text { (1994-1998) }\end{array}$ \\
\hline MPs editadas (média mensal) & 2,9 & 3,3 \\
\hline MPs reeditadas (média mensal) & 2,3 & 51,2 \\
\hline TOTAL (média mensal) & 5,2 & 54,6 \\
\hline $\begin{array}{l}\text { Percentual de projetos do Executivo } \\
\text { enviados como MP }\end{array}$ & 30,3 & 47,6 \\
\hline Percentual de MPs rejeitadas* & 7,9 & - \\
\hline $\begin{array}{l}\text { Percentual de MPs modificadas pelo } \\
\text { Congresso }\end{array}$ & 59,6 & 23,0 \\
\hline $\begin{array}{l}\text { Percentual de MPs transformadas em lei } \\
\text { (inclui leis de origem do legislativo) }\end{array}$ & 74,2 & 50,3 \\
\hline
\end{tabular}

Fonte: PRODASEN; Banco de Dados Legislativos, CEBRAP.

* a diferença se deve a MPs que perderam a eficácia e não foram reeditadas e MPs em tramitação.

Por outro lado, TEIXEIRA (1997, p. 195) ressalta "o caráter insular desse projeto de reforma, que não se insere em uma proposta mais orgânica de mudança nas principais áreas críticas, ao contrário do que se deveria esperar de um projeto de redesenho do aparelho estatal". 
O tratamento dado ao setor saúde no projeto de reforma do governo é uma ilustração do que se acaba de dizer. Após anos de luta, a partir dos anos 70, o Brasil, através de um movimento de esquerda, consegue vitórias substanciais do ponto de vista jurídico-constitucional para a implantação da chamada Reforma Sanitária e do Sistema Único de Saúde ${ }^{10}$

No entanto, com a opção politica do governo FHC, que separa e distingue os serviços públicos estatais dos serviços públicos não-estatais, o Sistema Único de Saúde/SUS é crescentemente responsabilizado pelo aumento da segmentação e da iniqüidade da saúde no Brasil. Com a implantação das medidas que visam a reforma do aparelho de estado, o SUS teria reforçado seu aspecto de politica pública dirigida aos pobres, precariamente compensatória das desigualdades sociais no Brasil. Por outro lado, aparece a necessidade de formulação de propostas e medidas capazes de transformar a administração püblica, e, por efeito, a administração do setor saúde, que se traduzam, como afirma COHN (1997, p. 170), "em instrumentos de construção de uma nova ordem social que articule democracia política e democracia social".

As conseqüências de tais opções repercutem sobre o cotidiano da população que busca serviços públicos de saúde, estatais ou não, e sobre a reforma do estado no Brasil. Esta reforma, segundo ARRETCHE (1997), deveria contemplar o controle público, fundamental para o avanço não só da democratização do estado brasileiro, mas da sua relação com a sociedade e não apenas de meros ajustes visando manter sob controle a crise econômica brasileira.

\footnotetext{
${ }^{10}$ A Reforma Sanitária, movimento político iniciado a partir da metade dos anos 70 obteve vitórias significativas no campo jurídico-legal com a Constituição Federal de 1988, que assegura a saúde como direito de todos e dever do estado. Posteriormente com a Lei 8080 de 1990 é criado o SUS/Sistema Único de Saúde, formulado com base nos princípios de universalidade, eqüidade, democratização e controle social.
} 
A condução atual da reforma do aparelho de estado pelo governo Fernando Henrique Cardoso, em particular a parceria entre o público e o privado na saúde, que visa a substituição de um pelo outro, terá repercussão fundamental sobre o processo de gestão no setor público. Além de aspectos inconstitucionais (MINISTÉRIO PÚBLICO FEDERAL 1998) e de não considerar o próprio SUS no seu arcabouço jurídico-institucional, este modelo também não leva em conta o fato de que a cultura existente em nosso país não é fundada no interesse público e o controle social ainda é incipiente, em relação tanto aos serviços públicos quanto aos privados (VIANA 1997).

No entanto, a crise brasileira da saúde parece indicar que não é a adoção de "modelos" que modifica a situação existente. 0 exemplo do PAS $^{11}$, no município de São Paulo, demonstra que a lógica da "racionalidade" não pode superar os graves problemas que o setor saúde vem enfrentando (COHN e ELIAS 1999). Neste sentido, nem a privatização da saúde, nem a implantação de organizações sociais, nem o aparato juridico-legal que sustenta o SUS constituem-se em desenho suficiente para o desenvolvimento da articulação necessária entre a técnica e a política visando à superação deste panorama.

${ }^{11}$ O PAS, Plano de Atendimento à Saúde, foi aprovado e implementado no municipio de São Paulo durante o govemo Paulo Maluf, em 1996, em que cooperativas médicas passaram a gerir e prover serviços de saúde para o sistema público. O PAS pode ser considerado como uma nova configuração do setor público estatal na busca de racionalidade entre custo/efetividade. Sobre o tema ver: Secretaria Municipal da Saúde de São Paulo. Plano de Atenção à Saúde - PAS. Resumo executivo. São Paulo, SMS, 1996; Secretaria Municipal da Saúde de São Paulo. Plano de Atenção à Saúde- PAS: projeto básico. Versão 2, São Paulo sd. e Cohn A e Elias PE (coordenadores). O público e o privado na saúde. O PAS em São Paulo. São Paulo: Cortez editora/CEDEC, 1999. 
Considerando que são irreversiveis as medidas atuais de privatização de serviços de saúde no Brasil, é preciso aprofundar a discussão politica da questão. Primeiro, porque este é o único caminho possivel para assegurar aos cidadãos brasileiros, a maioria pobres que não conseguem nem mesmo um acesso universal ao SUS, o direito à saúde. $E$ em segundo lugar, porque não serão medidas gerenciais que poderão resolver a crise do sistema de saúde, que em todo o mundo vem se revelando uma crise estrutural e não transitória.

SOUSA SANTOS (s/d) propõe distinguir claramente o papel de complementariedade entre o estado e um terceiro setor. Para ele esta diferença está baseada na própria distinção que se faz das funçōes exclusivas e não-exclusivas do estado. "Por trás desta distinção está a idéia de que, sempre que o estado não demonstre ter uma vantagem comparativa, deve ser substituidos no exercicio das funções não-exclusivas por instituições privadas mercantis do terceiro sector. Esta distinção é altamente problemática, sobretudo porque análise da génese do Estado moderno revela que nenhuma das funções do Estado foi originalmente exclusiva dele; a exclusividade do exercicio de funçōes foi sempre o resultado de uma luta política. Não havendo funções essencialmente exclusivas não há, por implicação, funçōes essencialmente não exclusivas" (p. 16). A questão fundamental, segundo o mesmo autor, seria o da "refundação democrática da administração pública", onde se poderão criar os meios de compatibilizar a eficiência com eqüidade e democracia.

Este caminho está sendo apontado muito mais pelo processo de descentralização na saúde do que com as medidas de reforma da administração pública num sentido estrito (ABRUCIO e COSTA 1998). E, dentre os aspectos que devem ser aprofundados no campo político, está o do financiamento para assegurar uma assistência equânime e o controle social dos serviços estatais e privados. 


\subsection{A descentralização da saúde no Brasil}

Algumas consideraçōes teóricas são necessárias para distinguir os aspectos que me interessam quanto ao processo de descentralização do setor saúde e que nos leva à municipalização e, por sua vez a implantação dos chamados distritos sanitário. É importante sublinhar que não aprofundarei a discussão sobre as características do processo de descentralização na saúde, já debatidos por vários autores e objeto de estudos especificos, tampouco das controvérsias sobre 0 termo "descentralização" (MALIK e VECINA NETO 1990; TEIXEIRA 1990, 1992; JACOBI 1991; DOWBOR 1991, 1994; UGÁ 1991, 1997; ARRETCHE 1997; COHN 1997; GUIMARĀES 1997, 2000; JUNQUEIRA 1997; BORGONOVI 2000).

A descentralização é defendida por autores de diversas correntes de pensamento e apontada como possivel solução para problemas em contextos diferentes. As mudanças na administração pública em vários paises do mundo no final dos anos 90 retomam o conceito de descentralização como um pressuposto fundamental na implantação de um welfare mix ou welfare society em paises europeus, em que a instituição pública vem considerada como um fator de produção, dada a perda de função de um estado central e reconhecimento da autonomia de entes locais (BORGONOVI 2000).

No setor saúde, a descentralização é analisada numa perspectiva favorável a diversos tipos e graus de transformação pelos quais deve passar o sistema público de saúde no Brasil.

GUIMARĀES (1997), ao revisar os conceitos utilizados nos estudos sobre descentralização, identifica sua inserção em dois planos - o jurídico e o político-institucional - e três dimensões: social, política, e administrativa. Deste modo, a discussão sobre a descentralização abarca aspectos que 
partem da sua compreensão enquanto estratégia para ampliar a participação social na formulação e controle de políticas públicas, ou de aspectos decorrentes, como a transferência de recursos financeiros e de competências técnico-administrativas. Segundo esta mesma autora, quanto à especificidade deste debate na saúde, a discussão sobre a descentralização se revela através de três vertentes principais: 1. descentralização compreendida como racionalidade na organização e oferta de serviços de saúde; 2 . descentralização como um conceito estratégico visando a reforma e democratização das politicas de saúde; 3 . descentralização como um princípio que permite analisar interesses e intermediações das tendências da reforma em saúde. A mesma autora vai além ao tornar claro 0 caráter diferenciado entre a proposta de descentralização assumido pela reforma sanitária brasileira: a democratização do sistema de saúde, maior eficiência local e maior controle social, e o defendido na proposta de reforma de estado do governo FHC, em que a descentralização é assumida como estratégia de racionalização de recursos (GUIMARÃES 2000).

Como a descentralização, na América Latina, tem sido utilizada também como estratégia de mudança, inclusive para apoiar a reestruturação do estado e a gestão de politicas como as de saúde (JUNQUEIRA 1997), a sua identificação em situaçōes concretas é parte da análise do contexto onde se insere o nosso estudo de caso. Isso porque, concordando com esse autor, entendemos que o intenso discurso sobre descentralização, na saúde, não se converteu necessariamente em uma nova prática e que não existe uma relação necessária entre descentralização, participação e eficácia da gestāo em saúde.

Até porque desde a Constituição de 1988 o Brasil é, por lei, um dos paises mais descentralizados, na distribuição tanto de recursos tributários quanto de poder político (SOUZA 1996). No entanto, neste processo, o município passou a ser visto como um espaço de possibilidades do 
gerenciamento mais eficiente dos recursos públicos, o que é ainda mais acentuado na gestão de saúde (COSTA 1996).

No processo de municipalização em prática no setor saúde, especialmente quanto ao seu aspecto político-institucional, contempla-se a desagregação do poder em diferentes modalidades. Alguns autores identificam, neste processo, muito mais uma transferência de responsabilidades e competências para a esfera municipal do que, propriamente, uma redistribuição do poder de decisão. Isso porque é notória a dependência financeira dos municipios frente aos governos regional $e$ central e as ingerências politicas eleitorais na formação de novos municipios (GUIMARÃES 1997, 2000; JUNQUEIRA 1997).

SOUZA (1996), em estudo de caso sobre o impacto da descentralização e democratização no município de Salvador em 1996, conclui que esta capital não foi beneficiada pela descentralização política e financeira, estando a administração municipal dependente de aporte de recursos das outras esferas de governo. Esta dependência, segundo a autora, tem condicionado dois fatores. Tem: 1. impedido a ação dos políticos locais em beneficio da coletividade; 2 . estimulado uma ação visando resultados imediatos, em detrimento de projetos em longo prazo. Por outro lado, a autora também ressalta a distância entre o recebimento de maior volume de recursos econômicos e a melhoria das condições de vida da população.

JUNQUEIRA (1997) indica esta mesma direção em sua análise da descentralização. Para ele, as demandas sociais ainda estão aquém do que é exercido no processo de descentralização e municipalização, "pois as transferências federais, privilegiando áreas menos desenvolvidas e municipios de menor porte, deixam a descoberto as grandes cidades $e$, especialmente, as regiões metropolitanas que concentram a pobreza" (pp. 191-192). 
Mesmo assim, o papel constitucional atribuido aos municipios tem gerado mudanças na gestão em saúde e a municipalização tem sido considerada como impulsionadora deste movimento. O municipio pode ser visto como um espaço, ainda que limitado, de conflito e negociaçāo, onde podem estar surgindo algumas inovações na administração pública subnacional (FARAH 1997).

No entanto, sem uma mudança na capacidade fiscal e de gastos e na própria capacidade administrativa, os municípios não serão capazes de criar soluções para as muitas desigualdades sociais existentes, o que pode ser afirmado também em relação ao setor saúde (ABRUCIO e COUTO 1996).

Assim, na análise desenvolvida neste estudo a municipalização aparece como referência da política formal existente no municipio de Salvador mas sem repercussões significativas na prática da gestão no distrito sanitário. Deste modo, analisar o referencial sobre descentralização e municipalização permitiu, enquanto elemento do contexto, um confronto entre o que explicita tais propostas em teoria $e$ as relações entre a municipalização e o cotidiano da gestão local em saúde, no seu caráter de política posta em prática.

\subsection{A gestão em saúde no Brasil: cenários}

No contexto da municipalização da saúde surge uma nova discussão sobre o que se nomeia como novos modelos de gestão, capazes de serem criados a partir da realidade local e tendo como referência os principios e diretrizes do SUS. 
Os eixos da discussão sobre a crise do estado brasileiro sempre estiveram entre o papel relevante da precariedade dos instrumentos e capacidade de gestão do setor público estatal e num papel secundário a capacidade de execução das políticas públicas.

Por conseguinte, a discussão sobre gestão na saúde deixa transparecer esta mesma dificuldade em identificar os elementos que constituem os pontos-chave de intervençăo na busca de mudanças.

Por outro lado, aumenta a dificuldade desta discussāo a característica do processo coletivo de trabalho em saúde ser particularizado pelo fato de que o seu produto é utilizado ou consumido pelo seu usuário. Incorporada neste trabalho, a gestão de serviços e de sistemas de serviços de saúde é, por conseguinte, considerada uma tarefa de alta complexidade. O campo da gestão em saúde é foco permanente de debates e está aberto às investigaçōes que permitam compreender este fenómeno em todas as suas múltiplas dimensőes.

No contexto atual do Brasil, ainda que se desenvolvam estudos e análises sobre a gestão no campo público, identifica-se pouca clareza quanto às condiçōes de gestāo que podem otimizar os recursos existentes e propiciar serviços sociais, nos quais se incluem os serviços de saúde, em qualidade e quantidade satisfatórias ao conjunto da populaçăo.

Uma dificuldade quase sempre esquecida é o fato de que não existe formalmente um sistema de serviços de saúde no Brasil, ainda que exista uma agregaçăo territorial dos serviços públicos de saúde em áreas de abrangência, conhecidos como distritos sanitários ou distritos de saúde.

Em geral, as formas de gestão com novas características são oriundas do setor privado e servem como modelos para o setor público. 
Segundo o estudo realizado pela FUNDAP (1997) sobre novas formas de gestão dos serviços públicos no estado de São Paulo, a gestão pública poderia ser tipificada em três modelos: o primeiro, que seria uma forma de gestão pública corrigida, onde a administração pública está presente no financiamento, gestão e prestação dos serviços com a participação consultiva de agentes privados nos processos públicos de decisão; segunda, a gestão delegada mista, caracterizada pela participação na gestão da administração pública e do setor privado, através de acordos e estruturas organizacionais especificas; e o terceiro, a gestão delegada pura, onde a administração pública promove e garante a efetivação de atividades sendo a prestação de serviços e a gestão de responsabilidade do agente privado

Este último modelo é o adotado na implantação de organizaçōes sociais na saúde, principalmente em substituição ao hospital governamental tradicional.

Hoje, a implantação das organizações sociais de saúde já é uma realidade e deve ser objeto de estudos especificos para revelar seu impacto no setor saúde. Ainda que não existam estudos analíticos sobre o tema, trabalho realizado por TANAKA e MELO (2000) indica que não há elementos substantivamente diferentes na gestão da organização social em saúde. No estudo de caso realizado no estado de São Paulo os destaques estão nos méritos (técnicos/éticos) das pessoas responsáveis pela gestão e não na adoçāo de "novos" modelos gerenciais. Os recursos financeiros, assegurados exclusivamente pelo governo estadual, têm garantido a prestação também exclusiva de serviços ao SUS. E, diferentemente do que acontece nas organizações públicas estatais, os recursos são repassados regularmente e em quantidade suficiente para assegurar os serviços de saúde prestados. 
Enquanto um processo de descentralização que imprime apenas uma maior racionalidade ao estado (COHN 1999), a implantação de organizações sociais na saúde não tem apontado para formas concretas de democratização da gestão ou contribuído na ampliação do controle social.

Não se pode assegurar, portanto, que a partir delas possa surgir um novo modelo de gestão na direção apontada por CECílLIO (1999, pp. 28-29): com um formato estrutural mais horizontal, com menor quantidade de niveis decisórios e com um processo de trabalho coordenado por equipes multiprofissionais

Hoje, são diversas as vertentes teóricas que contribuem para a compreensão do que se chama a gestão em saúde, desde elementos introduzidos pelo planejamento estratégico-situacional de Carlos Matus (MATUS 1993) à Atenção Gerenciada ${ }^{12}$. No entanto, um aspecto que parece consensual no atual debate sobre a gestão em saúde é a sua importância, bem como a busca de novos modelos de gestão para a realidade brasileira.

Dentre as discussōes das "novas" formas de gestão em saúde por autores brasileiros e latino-americanos (CAMPOS 1981; KLIKSBERG 1988, 1993, 1996; GALLO 1992; MENDES 1993; CAMPOS 1994, 2000; CECILIO 1994, 1997; TESTA 1995, 1997; FUNDAP 1997; MERHY 1997c, 1997d,

\footnotetext{
${ }^{12}$ Ainda que nåo seja objeto especifico explicitar e discutir tais conceitos, refere-se para uma melhor compreensão do planejamento estratégico-situacional a obra: Matus C. Politica, Planejamento e Govemo. Brasilia (DF): IPEA; 1993. 2v. Para uma critica deste modelo ver Uribe Rivera FJ. Agir Comunicativo e Planejamento Social: Uma Crítica ao Enfoque Estratégico. Rio de Janeiro: FIOCRUZ; 1995. Já a discussão sobre a Atenção Gerenciada (Management Care), adotada por vários paises no mundo e introduzida no Brasil através do setor privado lucrativo, pode ser encontrada em Almeida CM. As Reformas Sanitárias dos anos 80: crise ou transiçăo? Rio de Janeiro; 1995, [Tese de Doutoramento, Escola Nacional de Saúde Pública/FIOCRUZ]; Merhy EE. $O$ ato de govemar as tensర̋es constitutivas do agir em saúde como desafio permanente de algumas estratégias gerenciais. Ciência e Saúde Coletiva 4(2): 305-314, 1999, bem como em uma vasta literatura, principalmente americana, o que foge aos nossos objetivos.
} 
1999, 2000), pode-se identificar quatro cenários teóricos que agrupam características de modelos de gestão pública da saúde, considerados como mais importantes para o foco da investigação.

- A aproximação do planejamento com a gestão, que propunha, em principio, a redução dos elementos que definem e separam estas duas áreas. Esta aproximação visava, sobretudo, compreender e agir na gestão do setor público de saúde de um modo descentralizado e democrático. Isto se daria através da divisão de poder e participação ativa dos diversos sujeitos envolvidos no processo de planejamento/gestão. Os elementos introduzidos pelo planejamento exigiam, por sua vez, um aprofundamento em busca de novos modelos de gestão, adequados à realidade brasileira. Nesta concepção, as organizaçōes de saúde e, dentro delas, o processo de gestão são realizados e definidos por pessoas em diversas posiçōes e portador de diferentes valores e concepçőes.

- A compreensão da gestão em saúde enquanto um trabalho concreto, isto é, compreendida como o que as pessoas fazem quando trabalham (TESTA 1997). Esta concepção, que não elimina fatores destacados no ponto anterior, tem uma aproximação com o campo da "micropolítica do trabalho vivo"13 como discutida por MERHY (1997a, 1999). Neste sentido, a gestão é a prática de sujeitos institucionais e não institucionais, capazes de produzir "potências singulares" neste processo, que podem inclusive ser compreendidas como inovadoras. Tais aspectos remetem à temática da gestão cotidiana em saúde, para MERHY (1999, p. 306) “(..) terreno da produção e cristalização dos modelos de atenção à saúde, aos processos de mudanças que permitem instituir novos arranjos no

\footnotetext{
${ }^{13}$ Merhy desenvolve sua discussão do trabalho vivo buscando romper com o instituido, utilizando-se de bases teóricas da análise institucional e mais especificamente da corrente chamada de esquizoanálise. A este respeito ver as obras referidas deste autor, bem como a de Baremblitt G. Análise Institucional e Outras Correntes. Teoria e Prática. $3^{20}$ ed. Rio de Janeiro: Rosa dos Ventos; 1996 e Lapassade G. Les Microsociologies. Paris: Ed. Economica; 1996.
} 
modo de fabricar saúde, ao configurarem novos espaços de ação e novos sujeitos coletivos, bases para modificar o sentido das ações de saúde, em direção ao campo de necessidades dos usuários finais". A gestão em saúde se processa, portanto, em lugares distintos onde as mudanças podem ser analisadas com base “(...) em alta concentração de poder para movimentar um setor instituido muito bem estruturado, e por isso de alto poder conservador, ou está calcado em estratégias que explorem as tensões-potências para gerar novos desenhos territoriais (Guattari 1990) e novas direcionalidades no agir em saüde" (MERHY 2000, p. 65).

- "Modelo" de gestão, de caráter democrático e descentralizado em todos os niveis da organização, como proposto por CAMPOS $(1992,1994) \mathrm{e}$ CECÍlIO (1994, 1999), considerado como uma das poucas alternativas existentes no contexto brasileiro. Esta concepção aponta os mecanismos que perpassam a gestão do poder, considerada como fundamental para a implementação de novos modelos de gestão que conciliem diretrizes antagônicas e não apenas introduzam novas tecnologias. CAMPOS (2000) destaca como fatores componentes dessa proposta: 1. operacionalização da descentralização com base na delegação de autonomia às equipes de saúde, que seriam responsáveis por atribuiçōes especificas; 2 . estabelecimento de um contrato de gestão envolvendo uma negociação entre governo, trabalhadores e clientes e que fosse a base do autogoverno da saúde em cada espaço definido. Posteriormente, o mesmo autor defende a construção de sistemas de cogestão e não de autogestão, que abarcariam uma nova lógica para a distribuição do poder, apoiando e ampliando a capacidade de direção de todos os trabalhadores e não somente dos dirigentes de uma dada organização. Esse seria um processo em que ao mesmo tempo fossem construidos, numa troca dialética, tanto um novo modelo de gestão quanto novos sujeitos coletivos capazes de enfrentar a racionalidade gerencial dominante. 
- A gestão como parte do empresariamento do setor saúde, o que inclui a valorização da profissionalização da função gerencial. A adoção de um "modelo empresarial" que em teoria deve possibilitar a desburocratização da gestão em saúde e a introdução de elementos mais racionais nos processos para melhor combinar quantitativamente e qualitativamente os recursos disponiveis. Nesta lógica, deveria existir, principalmente nos serviços públicos estatais, uma clara separação entre órgãos responsáveis pelas escolhas políticas e órgãos responsáveis pelas escolhas técnicas.

Nesse estudo, adoto como perspectiva conceitual compreender a gestão em saúde não como um modelo prescrito (considerada aqui como a gestão abstrata, instituida, formal e estática) e sim como a gestão real (concreta, informal e dinâmica) produzida no processo micropolitico do trabalho vivo no cotidiano da organização de saúde (CHANLAT 1995; TESTA 1997; MERHY 1999).

As bases teóricas adotadas permitem que a gestão em saúde possa ser interpretada em relação a:

1) o reconhecimento do espaço das práticas de saúde como de disputa e conformação de politicas e que este processo acontece, inclusive, em espaços microlocalizados do cotidiano da gestão;

2) a multiplicidade de sujeitos envolvidos no processo da gestão, o que indica que não somente nos espaços instituidos se produzem e expressam processos de gestão. Como afirma MERHY (2000, p. 61), "volto a lembrar que, em saúde, governa desde o porteiro de uma unidade de saúde qualquer, passando por todos os profissionais de saúde mais especificos, até 0 dirigente máximo de um estabelecimento"; 
3) que a produção no espaço micropolítico é sempre perpassada por um alto grau de incerteza e passivel de produzir mudanças, ou melhor, possibilitar a eclosão de potências;

4) que o espaço de produção das práticas de saúde, onde se podem incluir as práticas de gestão, é um espaço de organização e relações singulares, que podem produzir atos capazes de atravessar um modelo instituido;

5) por fim, que para mudar o processo de gestão e, conseqüentemente, do cuidado em saúde, é preciso considerar a arena institucional como perpassada pelo exercicio cotidiano individual e coletivo dos diversos sujeitos deste processo (MERHY 1997b).

Essa sintese revela alguns pontos fortes para pensar a gestāo na saúde no Brasil e ao mesmo tempo aponta as fragilidades inerentes à inexistência de "modelos" testados e analisados. Nesse sentido, o enfoque no cotidiano nos estudos da gestão em saúde ganha força, dado que podem contribuir para fazer surgir à tona as possibilidades criativas de processos que podem estar sendo postos em prática em realidades concretas. Para a consolidação dessas possibilidades, além da decisão política e do respeito à ética e aos princípios e diretrizes constitucionais, é preciso valorizar o desenvolvimento do potencial das pessoas como um caminho para a concretização de vários "modelos" de gestão que assegurem a universalidade, eqüidade e integralidade da atenção à saúde, bem como a democratização da gestão e o controle social estabelecido pelo SUS.

Neste sentido, uma discussão sobre a gestão pública em saúde que fosse direcionada para o que se chama gestão dos principios do SUS (TANAKA 2000) incorporando o político nos níveis locais, regionais e federal poderia trazer contribuições para a identificação de novos caminhos para 
abordar a gestão pública em saúde. Desse modo, ao município caberia direcionar os recursos existentes para a gestão inicial da universalidade e da integralidade da atenção à saúde a todos os cidadãos, com base na sua realidade e gerindo um contrato de gestão que permitisse o seu caminho na direção do equilíbrio para a construção da autogestão da saúde local.

Esta pode ser uma estratégia para incluir na agenda da saúde a lacuna identificada por DINIZ (1998) entre a capacidade de decisão do Estado versus a limitada disponibilidade de bons instrumentos de gestão, que para essa autora negam o ponto de estrangulamento fundamental na capacidade do Estado, que está no campo da execução de políticas.

Na mesma direção estão os pressupostos defendidos por CAMPOS (2000) e sintetizados anteriormente, quando se refere ao investimento que deve ser feito no desenvolvimento de capacidades para gerir o processo de decisão, e não apenas na introdução de "novas" tecnologias geralmente inspiradas nos modelos oriundos da gestão empresarial.

Isto posto, na Seção 4 passo a apresentar os elementos do contexto interno ao município de Salvador que guardam, em parte, relação com o contexto externo apresentado nesta Seção. Destaco as caracteristicas e o papel que a descentralização na saúde, traduzida no âmbito local como "municipalização", se conforma no espaço local. No início da Seção 5 apresento por sua vez as características e avaliação realizadas pelos atores locais quanto a gestão no Distrito sanitário Barra/Rio Vermelho. 


\section{O CONTEXTO INTERNO AO MUNICÍPIO DE SALVADOR}

\subsection{A descentralização/municipalização da saúde em Salvador: antecedentes}

No caso do municipio de Salvador, o processo de descentralização da saúde começa timidamente em 1987, com a vitória da oposição ao governo do estado da Bahia. A Bahia constitui-se em um dos primeiros estados no país a assumir as diretrizes emanadas da VIII Conferência Nacional de Saúde (BRASIL 1986) com a assinatura do convênio de adesão para implementação do SUDS/Sistema Unificado e Descentralizado de Saúde, considerado como estratégia de democratização e de construção da Reforma Sanitária brasileira (PAIM 1987, 1990; SECRETARIA DA SAÚDE DO ESTADO DA BAHIA 1988; VILASBÓAS 1998).

Quanto ao processo de descentralização/municipalização na capital do estado, o município de Salvador, este é iniciado no ano de 1991, através da incorporação, na estrutura da Secretaria Municipal da Saúde/SMS, dos distritos sanitários e da constituição na Lei Orgânica do Município do Conselho Municipal de Saúde (Lei n. 9015 de 7/6/91) e do Fundo Municipal de Saúde (Lei n. 4301 de 24/01/91). Mas não se registram avanços na sua operacionalização, uma vez que o papel da SMS como gestor do sistema local de saúde permanece o mesmo e os distritos sanitários, coordenados pela Secretaria do Estado da Saúde/SESAB, são apenas virtuais, dado que existiam mas não possuiam autonomia nem recursos próprios para gerir a saúde em seus respectivos territórios.

Em 1996, toma posse a prefeita Lídice da Mata (na época filiada ao PSDB e cuja vitória significou a derrota do grupo político então no governo do estado), que na sua proposta de campanha para a área da saúde indicava a descentralização como estratégia para mudar a saúde em Salvador (GOVERNAR A SAÚDE COM A FRENTE POPULAR 1992). 
A minha participação na gestão municipal de 1993 a 1996 (Administração Lidice da Mata/PSDB) permite tecer algumas considerações sobre o processo da municipalização no período, com base em anotaçōes de reuniōes e discussões entre membros da alta direção da SMS de Salvador à época. Tais consideraçōes devem ser lidas como a interpretação de uma observadora participante e devem servir de contraponto a várias outras "verdades'" circulantes.

Identifico que a "municipalização", como expressão das políticas públicas de saúde, fazia parte do discurso dos dirigentes municipais e do programa de governo. No entanto, existia uma percepção por parte de membros da equipe técnica no nivel central da SMS na época de que "está acontecendo um processo de que as pessoas (dirigentes) não quererem que esta (a municipalização) aconteça". Havia o reconhecimento da capacidade da SMS em assumir e gerenciar os distritos sanitários existentes em Salvador. Existia, inclusive, uma relação técnica com quatro distritos sanitários, através de apoio ao trabalho técnico local com discussões e acompanhamento das atividades através da realização de reuniōes sistemáticas, o que, no entanto, não era reconhecido oficialmente pela SESAB. Estes quatro distritos sanitários foram os incluidos na proposta apresentada pela SMS junto ao Conselho Estadual de Saúde, para serem cedidos na primeira fase da "municipalização": Distrito Sanitário de Pau da Lima, Barra/Rio Vermelho, Subúrbio Ferroviário e Cabula/Beiru (SECRETARIA MUNICIPAL DA SAÚDE DE SALVADOR 1994).

No entanto, a tensa relação política entre o governo municipal e o estadual e a inexistência de interesse político na municipalização permitiam uma expectativa quase nula de avanços neste processo durante o período de 1993-1996. Alguns fatores destacados como limitadores para o avanço da municipalização tinham relação com as divergências de condução politica entre os dois níveis de governos (municipal e estadual). Além disso, estava 
em jogo a perda de poder político pelo governo estadual, com o controle pelo município, por exemplo, do setor privado conveniado e contratado ao SUS.

A postura da administração central do municipio em relação ao processo de municipalização permitia uma interpretação do pouco valor político dado a esta proposta.

Isto pode ser exemplificado através de fatos como:

- A inexistência de acompanhamento do processo pela administração municipal, bem como a indefinição quanto a prazos;

- A inexistência de objetivos/metas claramente definidos;

- O longo tempo entre a conclusão da proposta de descentralização formulada pela SMS e sua apresentação a SESAB, cerca de um ano e meio depois da sua formulação, discussão e aprovação pelo Conselho Municipal de Saúde, sem que nenhuma explicação concreta fosse identificada para tanto. Para o grupo técnico da SMS isso significava falta de apoio da administração municipal à proposta da SMS.

A única iniciativa factual foi a constituição de um grupo composto por representantes da SMS e SESAB visando elaborar uma proposta quanto à situação dos trabalhadores da saúde pertencentes ao quadro da SESAB que deveriam ser cedidos ao municipio. A comissāo foi constituída em 12/1/95, sendo a portaria publicada no Diário Oficial do Estado e assinada pelo secretário de estado da saúde, tendo sua composição modificada em 30/8/95. A última reunião da comissão foi em 4/12/95. Durante sua existência, a comissão enfrentou dificuldades para efetivamente negociar uma proposta com a SESAB que permitisse o inicio, de fato, do processo de descentralização da saúde no município de Salvador. 
Basicamente, as discussões na comissão giraram em torno da questão "recursos humanos", dado que desde o início a SESAB alegava que não continuaria pagando os salários dos servidores estaduais que seriam "cedidos" à administração municipal.

Quando ao final de alguns meses, a SMS apresentou uma proposta de repasse gradual, em três fases, dos distritos sanitários, a intransigência da SESAB quanto à cessão de servidores criou um impasse nas discussões. $A$ SESAB também se recusava a continuar pagando, num primeiro momento, a chamada "produtividade", que em termos percentuais correspondia a maior parte do salário, na época, dos servidores estaduais. A partir deste impasse as reuniōes foram suspensas e nunca houve uma conclusão do processo de negociação.

Depoimentos de representantes da SMS na comissão, registrados na época, indicam que efetivamente a constituição desta comissão era apenas uma "formalidade" sem perspectiva de ser um efetivo espaço de negociação do processo de municipalização. Alguns destes fatos são identificados a seguir:

- A identificação do "tom de deboche" de alguns representantes da SESAB durante as reuniões da comissão, sobre temas propostos pelos representantes da SMS, ilustradas a seguir: (...) "Muitas vezes eu tinha vontade, olhava para fulana e sicrana, de dizer dá licença e ir embora, me retirar, eu sentia assim um certo deboche" (entrevista 1 com membro da comissão).

- O "tom de ameaça" por parte de representantes da SESAB quando insinuavam "repassar amanhã mesmo as unidades para a SMS", completando com a pergunta "vocês querem?" (entrevista 1 com membro da comissão, 1996). 
- O fato de que "todas as propostas da secretaria do municipio foram rechaçadas" (entrevista 2 com membro da comissão, 1996).

Por fim, existia plena conviç̧ão por parte de técnicos da alta direção da SMS de que este processo só se iniciaria caso ganhasse as eleições municipais um candidato do mesmo grupo político do governo do estado, o que efetivamente se concretizou em 1/1/1997, quando toma posse na administração municipal o grupo da mesma linha política do governo estadual (Administração Antônio Imbassahy/PFL).

\subsection{A descentralizaçāo/municipalização da saúde em Salvador: 1997-2000}

O período analisado a seguir corresponde à gestão municipal entre 1997-2000 (Gestão Antônio Imbassahy/PFL), conduzida pelo grupo político aliado ao governo do estado da Bahia.

Em março de 1997, a SMS elabora a proposta intitulada "Descentralização da Gestão das Ações e Serviços de Saúde no Municipio de Salvador (Bahia) (SECRETARIA MUNICIPAL DA SAÚDE DE SALVADOR 1997). Tal documento, referido como "projeto" explicita as diretrizes a serem assumidas para operar o processo de descentralização da saúde no município.

Em sintese, a proposta apresentada tem como objetivo organizar o processo de descentralização da saúde, utilizando como estratégias a reorganização do modelo assistencial, o programa de saúde da familia e a distritalização. Estabelece ainda três etapas sucessivas para o desenvolvimento do processo de descentralização, com a assunção de quatro distritos sanitários em cada etapa, mantendo assim a mesma 
proposta elaborada pela gestão anterior (SECRETARIA MUNICIPAL DA SAÜDE DE SALVADOR 1994).

Além disso, define as atividades que serão desenvolvidas para o alcance dos seus objetivos visando a implementação da municipalização através do alcance da Gestão Plena da Atenção Básica à Saúde, estabelecida pela Norma Operacional Básica 01/96, do Ministério da Saúde.

Em agosto de 1997 é publicada a nova estrutura da Prefeitura Municipal, oriunda da reforma administrativa realizada (SECRETARIA MUNICIPAL DA SAÚDE DE SALVADOR 1997). Através dessa reforma é criada na estrutura organizacional da SMS uma Coordenadoria de Distritos Sanitários com a finalidade de "coordenar, acompanhar e avaliar as ações e serviços de saúde no seu território, de acordo com o Plano Municipal de Saúde, articulando-se com outros setores governamentais e nãogovernamentais e assegurando a participação efetiva das instâncias colegiadas existentes no território (...)" (SECRETARIA MUNICIPAL DA SAÚDE DE SALVADOR 1997, p. 6). Tais finalidades devem ser exercidas através de duas subcoordenadorias: Subcoordenadoria de Vigilância Sanitária (com os setores de Ações e Serviços de Saúde e Vigilância Epidemiológica) e Subcoordenadoria Administrativa (com o Setor de Manutenção e Administração).

Em novembro de 1997 é divulgado o Plano Municipal de Saúde 19982001, estabelecendo como diretrizes prioritárias a "reorganização do modelo de gestão", tendo como linha de ação o "desenvolvimento institucional" e como projetos definidos a "manutenção da administração central e modernização administrativa" (SECRETARIA MUNICIPAL DA SAÚDE DE SALVADOR 1997, p. 16).

Encontra-se nesse documento a afirmativa de que "a efetiva implantação do processo de descentralização das ações e serviços de 
saúde em Salvador passa necessariamente pelo fortalecimento dos distritos sanitários e do papel de suas gerências na organização da atenção à saúde em sua área de abrangência. $O$ fortalecimento das gerências dos distritos sanitários permitirá o desenvolvimento do planejamento, programação, monitoramento e avaliação das ações e serviços de saúde de forma descentralizada permitindo maior eficiència do gerenciamento. É importante que as gerèncias dos distritos sanitários não se cristalizem enquanto meras instâncias burocráticas, mas venham a assumir o papel de propulsores de um processo social de mudança das práticas sanitárias, dirigido para a eficácia, eficiência, eqüidade e democratização do sistema local de saúde" (SECRETARIA MUNICIPAL DA SAÚDE DE SALVADOR 1997, p. 30).

No entanto, contrariando as expectativas dos que apostavam na agilidade e melhor organização do processo de municipalização pelo simples fato de existir uma identidade política entre os dois grupos de governo (estadual e municipal), essa só tem seu inicio formal em 1998, quando os distritos sanitários são assumidos pela SMS, que incorpora a rede básica de serviços de saúde então sob a gestão da SESAB.

Do ponto de vista dos gestores institucionais locais a municipalização ainda nāo se traduz em açōes concretas que estejam beneficiando o trabalho e conseqüentemente seus resultados.

\subsection{Política e governo local}

Os achados que são descritos e analisados a seguir foram obtidos através do estudo de caso no Distrito Sanitário Barra/Rio Vermelho. A análise destaca tanto as características políticas locais quanto à operacionalização da municipalização na perspectiva dos atores locais do Distrito Sanitário Barra/Rio Vermelho/DSBRV. O foco da análise foi sempre destacar os contrapontos e diferenças entre tais interpretações e as afirmações da SMS sobre o papel dos distritos sanitários nesse processo. 
Os reflexos das políticas de saúde no contexto do setor saúde, segundo os atores locais, revelam, quase sempre, um espaço de atuação com forte conotação conflituosa e uma preocupação permanente com, pelo menos, a manutenção de certas garantias quanto ao acesso a serviços de saúde bem como o exercício do controle social na gestão da saúde.

O governo local da saúde é francamente caracterizado como pouco democrático, refratário ao controle social, contrário aos interesses da população local e com tendência privatizante. Isso, contudo, não parece impedir o avanço que é identificado na própria organização de moradores em torno da questão saúde.

Não foi identificada nenhuma característica com conotação positiva na análise feita pelos informantes tanto à política e ao governo local da saúde no municipio de Salvador quanto para o DSBRV. O surgimento do tema condução da política local da saúde - foi espontâneo por parte dos entrevistados e membros dos grupos focais.

Os Quadros 2, 2a, 2b e 2c caracterizam a condução política do governo local segundo os autores das enunciaçōes 
Quadro 2 - Características na conduçăo do governo local na saúde, Salvador, 1999

\begin{tabular}{|c|c|c|}
\hline Característica & Como é descrita & Autor \\
\hline \multirow[t]{4}{*}{$\begin{array}{l}\text { Pouco } \\
\text { democrática }\end{array}$} & $\begin{array}{l}\text { Eu acho que se a gente tivesse um governo mais democrático teria um avanço maior. A gente } \\
\text { se esbarra ai com essa dificuldade de relacionamento com a própria estrutura do poder. Isso } \\
\text { eu falo sem esperar até do apoio do governo. Que não tem compromisso mesmo. }\end{array}$ & $\begin{array}{l}\text { Conselheiros } \\
\text { Locais de Saúde } \\
\text { (representantes } \\
\text { da comunidade) }\end{array}$ \\
\hline & $\begin{array}{l}\text { Isso é evidente, uma mudança muito grande na postura das pessoas, dos servidores quando } \\
\text { a gente vai nas unidades, né, a gente percebe. Há uma postura um pouco assim, até de } \\
\text { medo de falar as coisas, inclusive nós não podemos dizer que a gente vivia num clima de } \\
\text { democracia, mas há uma, uma piora considerável do ponto de vista da, da liberdade das } \\
\text { pessoas falarem, da liberdade das pessoas fazerem coisas, né? }\end{array}$ & $\begin{array}{l}\text { Membros do } \\
\text { CMS }\end{array}$ \\
\hline & $\begin{array}{l}\text { Mas só que... digamos que a política da prefeitura não está interessado nisso aí, se pensa ou } \\
\text { se não pensa. Ela quer que faça o que ela mandou fazer. }\end{array}$ & \multirow[t]{2}{*}{$\begin{array}{l}\text { Trabalhadores } \\
\text { da Saúde }\end{array}$} \\
\hline & $\begin{array}{l}\text { Disseram assim: "A gerente vai sair? Vai. Vai ter que sair mesmo porque os Conselhos Locais } \\
\text { estão incomodando". Conselhos Locais não podem ficar contra o estado agora nas eleiçōes. } \\
\text { Então é uma forma de você manipular, e é o que está acontecendo mesmo, manipulação das } \\
\text { lideranças e tudo mais. }\end{array}$ & \\
\hline
\end{tabular}


O "clima" autoritário na condução politica local se reflete claramente no cuidado dos gerentes e trabalhadores da saúde em participar da pesquisa. Vários dos grupos focais realizados com os trabalhadores serviram inclusive de espaço para a catarse das angústias desenvolvidas quanto às perspectivas de trabalho. Várias vezes referiram o fato de que momentos como o da pesquisa eram os únicos em que se permitiam falar ou melhor, em que era permitido falar.

$\dot{E}$ interessante destacar que nas entrevistas com gerentes das unidades de saúde não são encontradas referências sobre o processo politico. No entanto, em depoimentos espontâneos durante as observações, alguns em tom de confidência, os gerentes referiam-se às pressōes constantes do nivel central da SMS; à inexistência de respostas da SMS quanto às demandas locais; ao fato de que sabiam que não permaneceriam muito tempo no cargo dada à pressão que sofriam e o crescente descaso da SMS para com as solicitaçōes e necessidades dos serviços de saúde. Durante o trabalho de campo, duas das gerentes foram demitidas sem que nenhuma explicação fosse dada, mesmo quando solicitada pelos respectivos conselhos locais de saúde.

Durante os momentos de observaçōes foi possivel registrar vários depoimentos espontâneos sobre a presença de um assessor especial da secretária da saúde, cujo papel seria o de "fiscalizar" as unidades de saúde e manter contato com lideranças locais no sentido de cooptá-las através da oferta de empregos.

Boletins do SINDSAÚDE/BA, Sindicato dos Trabalhadores em Saúde do Estado da Bahia, no ano de 1999 denunciavam o não cumprimento de deliberações do Conselho Municipal da Saúde, a exemplo da Resolução N. 008/98, de 9/06/98, que estabelecia as diretrizes para a política de recursos humanos na cidade de Salvador (JORNAL DO SINDSAÚDE 1999). O Manifesto em Defesa da Saúde e da Cidadania, assinado por várias 
entidades (associações de bairros, sindicatos, núcleos de estudos da UFBA, diretórios estudantis) durante a V Conferência Municipal de Saúde, em novembro/1999, denunciavam o crescente "silêncio, a opressão e o medo dos profissionais da saúde, que testemunham diariamente o caos da saúde no municipio".

Quadro 2a - Características na condução do governo local na saúde, Salvador, 1999

\begin{tabular}{|l|l|l|}
\hline Característica & \multicolumn{1}{|c|}{ Como é descrita } & Autor \\
\hline $\begin{array}{l}\text { Refratária ao } \\
\text { controle social }\end{array}$ & $\begin{array}{l}\text { (..) o distrito diz que a Secretaria não quer muito } \\
\text { a parceria muito lado a lado, colado com a } \\
\text { comunidade. Aí eu já fico sem saber como é que } \\
\text { vou agir. Porque repasso tudo pra o Conselho. } \\
\text { Mas pelo que tô ouvindo, não é prá repassar as } \\
\text { coisas, né? (...) Mas não é de interesse fazer } \\
\text { isso. E, me disseram que foi dito lá na Secretaria } \\
\text { que comunidade lá, a gente cá. O Conselho } \\
\text { existe porque tem que existir, mas não com a } \\
\text { importância, com essa parceria que eu estava } \\
\text { pensando que poderia desenvolver. }\end{array}$ & $\begin{array}{l}\text { Snidade } \\
\text { Saúde }\end{array}$ \\
$\begin{array}{l}\text { A secretária não tem participado do Conselho. } \\
\text { Tem, eu acho, é, tem tido uma postura de } \\
\text { menosprezo até às decisões do Conselho. Ela } \\
\text { estabeleceu ultimamente uma audiência. Então } \\
\text { o Conselho se reúne, ela não participa. }\end{array}$ & $\begin{array}{l}\text { Membros do } \\
\text { CMS } \\
\text { (...). A secretária, atualmente, ela tem tido uma } \\
\text { postura de, de isolar o Conselho. Ela não pode } \\
\text { prescindir do Conselho porque tem alguns } \\
\text { elementos da legislação que impedem ela de } \\
\text { fazer isso. (...). Mas a postura dela com o } \\
\text { Conselho tem sido de isolamento, de } \\
\text { depreciação do Conselho. }\end{array}$ & \\
\hline
\end{tabular}


As caracteristicas destacadas são reforçadas por atitudes posteriores da administração municipal em relação ao Conselho Municipal de Saúde.

No início da gestão Antônio Imbassahy, houve revogação da composição existente dos conselhos locais de saúde através do Decreto-lei n. 11.469, de 11/11/1996 (SALVADOR 1997). Após a eleição para a prefeitura, em outubro de 2000, em que foi reeleito o prefeito, foi encaminhado pelo poder executivo o Projeto de Lei $n$. 180/00 reduzindo o número de membros do CMS (dos atuais 32 para 16) e assegurando a presidência como prerrogativa do secretário da saúde, aprovado pela câmara de vereadores em dezembro de 2000. Vale lembrar que na gestão 1997-2000 a secretária da saúde candidatou-se ao cargo de presidente tendo sido derrotada em eleição direta, assumindo a presidência do Conselho Municipal de Saúde um representante da igreja católica, reeleito para o segundo mandato. 
Quadro 2b - Características na condução do governo local na saúde, Salvador, 1999

\begin{tabular}{|c|c|c|}
\hline Característica & Como é descrita & Autor \\
\hline \multirow[t]{5}{*}{$\begin{array}{lr}\text { Contrária } & \text { aos } \\
\text { interesses da } \\
\text { população local }\end{array}$} & $\begin{array}{l}\text { (...). Mesmo porque a instituição governamental e os nossos dirigentes } \\
\text { govemamentais não tão nem ai pra quem é pobre, miserável, essa é a realidade, } \\
\text { certo? Muitas vezes eles procura fazer alguma coisa sim, se a comunidade se } \\
\text { reunir e se mobilizar e botar a boca no trombone. }\end{array}$ & \multirow[t]{2}{*}{ Usuários } \\
\hline & $\begin{array}{l}\text { A gente vê na televisão, nos programa de rádio, os postos tá tudo...Tão acabando } \\
\text { tudo. Não tem atendimento certo, não tem. }\end{array}$ & \\
\hline & $\begin{array}{l}\text { Assim, o movimento de saúde no distrito, ele vai independente do setor público; o } \\
\text { setor público tá indo numa direçăo e nós tamos indo em outra; é até o motivo dos } \\
\text { nossos conflitos. }\end{array}$ & $\begin{array}{l}\text { Conselheiros Locais de } \\
\text { Saúde (representantes da } \\
\text { comunidade) }\end{array}$ \\
\hline & $\begin{array}{l}\text { Porque a Prefeitura, o Govemo tem dinheiro, mas eles estão... sei lá o quê que } \\
\text { eles tão fazendo com o dinheirol E ai quando a gente vai, eles dizem que as } \\
\text { verbas năo deu... que tão cortando a verba; mas a gente vê que tem verba pra } \\
\text { outras coisas; mas o que é essencial pra comunidade não tem e a comunidade } \\
\text { não sabe... por quê, sei lá! }\end{array}$ & $\begin{array}{l}\text { Conselheiros Locais de } \\
\text { Saúde (representantes } \\
\text { dos trabalhadores da } \\
\text { saúde) }\end{array}$ \\
\hline & $\begin{array}{l}\text { Não há confiança, não existe confiança, não existe objetivo comum de ação. } \\
\text { Objetivo é apenas o que a secretaria a nivel central quer. Que necessariamente } \\
\text { não é o que a população quer, nem o que a maioria dos técnicos gostaria. }\end{array}$ & Trabalhadores da Saúde \\
\hline
\end{tabular}


A leitura das atas de reuniōes do CMS do periodo de janeiro/1997 a novembro/1999 aponta fatos e depoimentos que reforçam as características destacadas. Não se encontra nenhum registro de encaminhamentos sobre as deliberações importantes tomadas pelo CMS, reforçada por uma constante repetição dos pontos de pauta que são freqüentemente postergados para a reunião seguinte. Uma questão, a designação de recursos financeiros para garantir o funcionamento do CMS, é levantada e retomada em várias atas, sem registros de encaminhamentos sobre o assunto. Outro aspecto interessante é que a apresentação do relatório de gestāo do ano de 1998 não faz sequer referência à existência e às atividades do CMS e mesmo assim foi aprovado.

Destacamos o depoimento registrado na $144^{\mathrm{a}}$ Ata de reunião do CMS, em 24/2/99, em que a subsecretária da saúde responde a um questionamento de um dos conselheiros sobre a prestação de contas da SMS: "Esta alertou que a SMS não teria nenhuma nebulosidade em suas contas, e que o CMS poderia fiscalizar e analisar tudo o que desejasse, desde que autorizado pela senhora secretária (grifo meu), salvo auditor, o que seria competência do Tribunal de Contas (...)". 
Quadro 2c - Características na condução do governo local na saúde, Salvador, 1999

\begin{tabular}{|c|c|c|}
\hline Característica & Como é descrita & Autor \\
\hline \multirow[t]{4}{*}{$\begin{array}{l}\text { Tendência } \\
\text { privatizante }\end{array}$} & $\begin{array}{l}\text { Mesmo com conselhos organizados, com } \\
\text { tudo mais, a secretária nas últimas reuniōes } \\
\text { tem mostrado a tendência de que vai } \\
\text { comprar serviço. A idéia dela não é } \\
\text { estruturar os Posto com o dinheiro do SUS } \\
\text { como tá no plano municipal de saúde não. } \\
\text { (...) se a gente não avançar, não } \\
\text { aprofundar, a gente vai tá referendando a } \\
\text { privatização da saúde por outros moldes, } \\
\text { que é outra coisa que o sistema faz muito } \\
\text { bem. }\end{array}$ & \multirow[t]{2}{*}{$\begin{array}{l}\text { Conselheiros } \\
\text { Locais de Saúde } \\
\text { (representantes } \\
\text { da comunidade) }\end{array}$} \\
\hline & $\begin{array}{l}\text { Eu não sei se eu falei sobre as clínicas que } \\
\text { estão cobrando, que é SUS. O SUS é } \\
\text { público. (...) Porque o Dr. Fulano colocou } \\
\text { uma clinica lá, tá dizendo que tá atendendo } \\
\text { todo mundo e tá cobrando. Tem que } \\
\text { carimbar do SUS e ainda quer uma taxa. }\end{array}$ & \\
\hline & $\begin{array}{l}\text { Que às vezes eu fico pensando assim, se o } \\
\text { processo de privatização chegar, como ele } \\
\text { está chegando a nivel dos hospitais, a nível } \\
\text { dos centros de saúde, como existe na } \\
\text { Colómbia, em outros lugares, e os centros } \\
\text { de saúde passarem a ser, como tá } \\
\text { acontecendo em outros Estados, me } \\
\text { parece, ser ONGs, né? Eu não sei. }\end{array}$ & $\begin{array}{l}\text { Trabalhadores da } \\
\text { Saúde }\end{array}$ \\
\hline & $\begin{array}{l}\text { Eu fico pensando, o laboratório (refere-se } \\
\text { ao laboratório de um Centro de Saúde que a } \\
\text { SMS ameaça fechar), tantos anos, pra } \\
\text { acabar! Em vez de facilitar, tá dificultando. } \\
\text { O que tá acontecendo? Tem clínicas } \\
\text { conveniadas do SUS que tão cobrando! É } \\
\text { isso que eu falo, isso é só um exemplo. }\end{array}$ & $\begin{array}{l}\text { Gerente de } \\
\text { Unidade de Saúde }\end{array}$ \\
\hline
\end{tabular}


Durante as observações foram freqüentes as referências às irregularidades quanto à cobrança, por serviços privados relacionados ao SUS, de procedimentos. Vários desses serviços eram de conhecimento dos gerentes, trabalhadores e conselheiros de saúde. Outro fato relatado dizia respeito à crescente compra de novos serviços pela SMS ao mesmo tempo em que se agravavam as condições materiais de trabalho, quando se sabia que o município recebia recursos financeiros do sistema e não aplicava na melhoria dos serviços próprios.

\subsection{A descentralização/municipalização da saúde e o Distrito Sanitário Barra/Rio Vermelho}

O Distrito Sanitário Barra/Rio Vermelho/DSBRV teve sua "implantação" iniciada em 1988, dentro do processo de descentralização fomentado pelo Sistema Unificado e Descentralizado de Saúde, SUDS/BA. Desde esta época passou a existir uma delimitação geográfica da área sob responsabilidade do distrito e a indicação de uma equipe técnica mínima (pela SESAB), responsável pela prestação de ações e serviços de saúde nesse território. Mas, como visto anteriormente, somente em 1998 é que a os distritos sanitários sediados no município passam a ser de responsabilidade da SMS, ainda que existissem na estrutura organizacional desde 1991, incluindo o DSBRV. Entre 1997 e 2000, o DSBRV foi coordenado por três gestoras diferentes.

O DSBRV é um dos 12 distritos sanitários em que se divide a cidade de Salvador e corresponde a 21 agrupamentos de bairros localizados ao sul da península da cidade, com uma área de $20,22 \mathrm{~km} 2$ e uma população de 329.344 habitantes (SECRETARIA MUNCIPAL DA SAÚDE DE SALVADOR 1999), conforme ilustrado na Figura 3. 
Figura 3 - Mapa da cidade do Salvador, Bahia, com destaque para a área correspondente ao Distrito Sanitário Barra/Rio Vermelho

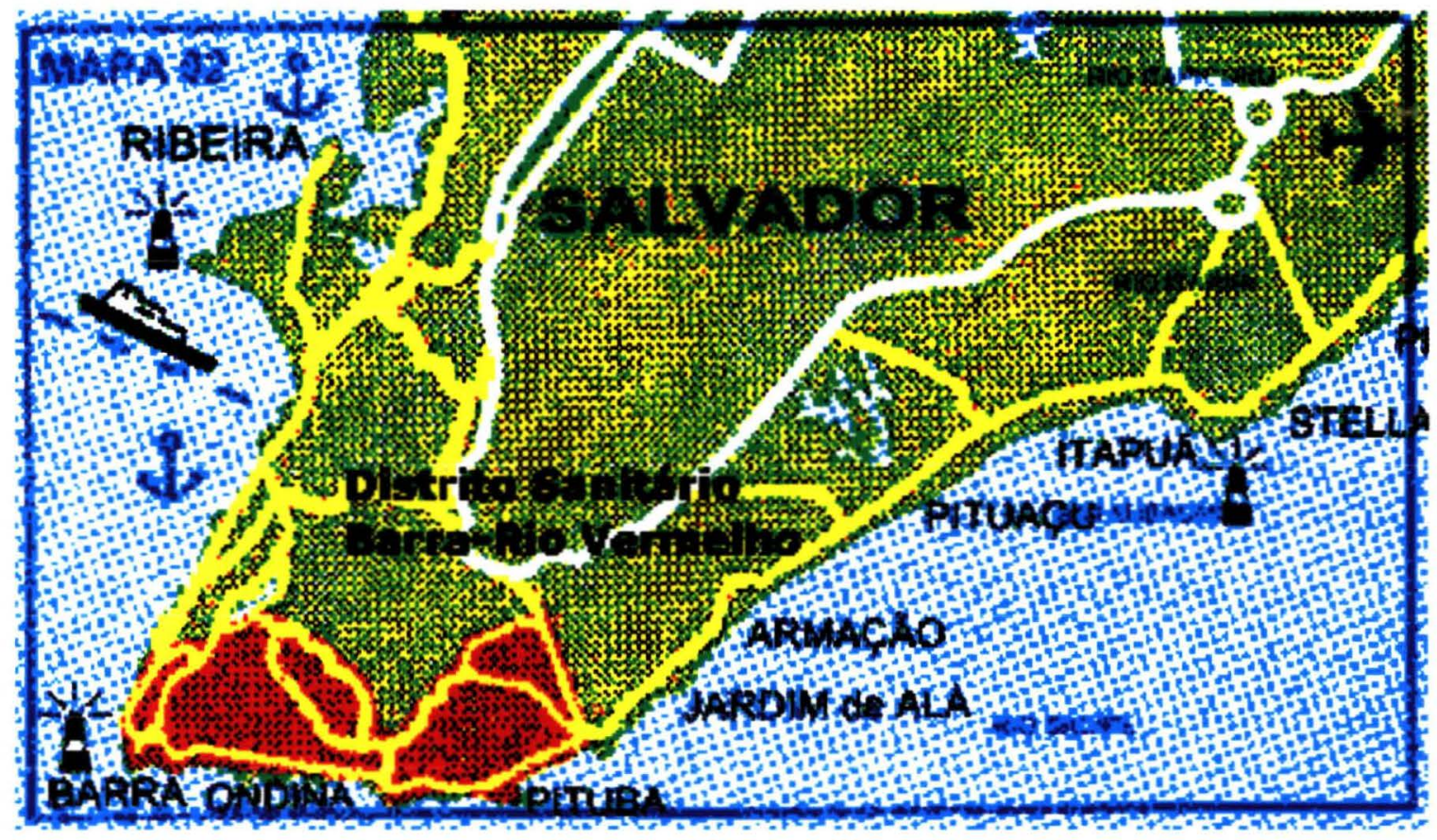

Os bairros do DSBRV possuem uma grande diversidade socioeconômica, com uma maior concentração de bairros considerados de classe média alta e em menor expressão bairros populares, com condições de vida bastante precárias. Segundo pesquisa realizada em 1995 (PAIM e col. 1997) considerando a renda familiar, 3,65\% das famílias no DSBRV estão classificadas como sem rendimento e $17,94 \%$ com rendimento de até um salário mínimo. Na sua população, apenas $56,78 \%$ das crianças de 5 a 9 anos são alfabetizadas e entre os chefes de família 93,49\% o são. Quanto à situação dos domicílios, 91,91\% possuem abastecimento de água com canalização interna e 95,71 \% com canalização ligada à rede geral. Quanto à instalação sanitária, $96,32 \%$ a possuem contra $2,19 \%$ que não a possuem. 
Os Quadros 3 a 6 seguintes apresentam as principais características da municipalização na perspectiva de atores desse processo. $O$ tema central foi definido a partir do foco da unidade de análise selecionada nas falas dos informantes no estudo de caso realizado no DSBRV.

O Quadro 3 apresenta a perspectiva valorativa dos atores quanto à condução política da municipalização.

$\mathrm{Na}$ análise, faço um contraponto entre as diretrizes estabelecidas no Plano Municipal de Saúde e a descrição de alguns temas central selecionados, quando pertinente. 
Quadro 3 - O processo de municipalização da saúde numa perspectiva valorativa

\begin{tabular}{|c|c|c|c|}
\hline Tema & Como é descrito & Autor & Valor \\
\hline \multirow[t]{4}{*}{$\begin{array}{l}\text { Conduçăo } \\
\text { politica }\end{array}$} & $\begin{array}{l}\text { Tem alguns funcionários que ainda tem resistência, né? Ao processo de municipalizaçăo. Tem funcionários da } \\
\text { SESAB que apresentam uma resisténcia muito grande, ao processo. Acham que perderam, acham que deixaram } \\
\text { de ganhar. Eu, pra mim, particularmente, năo entendo aonde. Porque do que eu conheço da SESAB até hoje năo } \\
\text { mudou em nada, o salário năo diminuiu, porque na verdade, como eu estava dizendo, na gestăo, o salário, o ónus } \\
\text { continua, ainda é da SESAB. A produtividade caiu, mas é toda uma estrutura da SESAB como um todo. (...). }\end{array}$ & $\begin{array}{l}\text { Membro da } \\
\text { Coordenaçăo } \\
\text { do DSBRV }\end{array}$ & $\begin{array}{l}\text { Negativo: } \\
\text { Resistência dos servidores da } \\
\text { SESAB } \\
\text { Queda da produçăo de } \\
\text { serviços nas unidades básicas } \\
\text { como um todo }\end{array}$ \\
\hline & $\begin{array}{l}\text { A participaçăo dos trabalhadores em saúde tá sendo muito difficil no processo de municipalizaçắo. Muito diffcil. A } \\
\text { gente vê um foco de atividades, de atuaçăo, por parte dos moradores. Os moradores sim: se reúne, reivindica, faz } \\
\text { sua pauta e al.... }\end{array}$ & \multirow[t]{3}{*}{$\begin{array}{l}\text { Membros do } \\
\text { CMS }\end{array}$} & $\begin{array}{l}\text { Positivo: maior mobilizaçăo } \\
\text { dos moradores } \\
\begin{array}{l}\text { Negativo: resistência dos } \\
\text { trabalhadores da saúde }\end{array}\end{array}$ \\
\hline & $\begin{array}{l}\text { A municipalização se deu em Salvador, faz um ano e os profissionais, eles estăo completamente alheios às } \\
\text { informaçőes, entendeu? Ele não sabe o que é, muitos deles năo sabe o que é municipalização! Um } \\
\text { problema! E o que foi isso? Falta de informação, para quem estava na } \\
\text { ponta, produzindo. }\end{array}$ & & $\begin{array}{l}\text { Negativo: desinformaçáo dos } \\
\text { trabalhadores no processo }\end{array}$ \\
\hline & $\begin{array}{l}\text { Porque a Secretaria Estadual de Saúde entregou os postos de saúde, completamente sucateados fisicamente. } \\
\text { Entăo, era necessário que a Secretaria de Saúde do Estado fizesse a reforma e entregasse ao municlpio de forma } \\
\text { muito mais organizada. E isso nåo aconteceu em nenhuma instáncia. }\end{array}$ & & $\begin{array}{l}\text { Negativo: repasse da rede em } \\
\text { precárias condiçð̌es de infra- } \\
\text { estrutura }\end{array}$ \\
\hline
\end{tabular}


Ao analisar a condução no processo de municipalização da saúde os atores locais fazem um balanço negativo deste. A forma como este processo está acontecendo exclui a participação dos profissionais de saúde do DSBRV, que não têm acesso às informaçōes $e$ destacam certo grau de "desapontamento" com a municipalização. Ao lado da falta de informação existe uma nítida confusão quanto às iniciativas da SMS, principalmente com relação ao aumento da compra de serviços do setor privado e às condições materiais de trabalho, consideradas precárias pelos profissionais da saúde. O único aspecto positivo é a existência de um grau permanente de mobilização das associações de moradores, através de seus representantes nos conselhos locais de saúde, e o maior acesso às informações por conta das articulaçōes politicas que realizam, diferentemente dos trabalhadores da saúde. 
Quadro 4 - Impacto da municipalização no DSBRV

\begin{tabular}{|c|c|c|c|}
\hline Tema central & Como é descrito & Autor & Valor \\
\hline $\begin{array}{l}\text { Impacto no } \\
\text { papel do distrito } \\
\text { sanitário }\end{array}$ & $\begin{array}{l}\text { E o distrito só passou a ser } \\
\text { importante agora na } \\
\text { municipalizaçăo. Entăo como ele } \\
\text { está se transformando num } \\
\text { espaço politico "eleitoreiro", entåo, } \\
\text { a força e o poder desse distrito é } \\
\text { maior do que era anteriormente, } \\
\text { óbvio. }\end{array}$ & \begin{tabular}{|l|} 
Trabalhadores da \\
Saúde
\end{tabular} & $\begin{array}{l}\text { Positivo: } \\
\text { Valorizaçăo politica } \\
\text { do DS } \\
\text { Negativo: Uso } \\
\text { político eleitoral do } \\
\text { DS }\end{array}$ \\
\hline $\begin{array}{lr}\text { Impacto } & \text { no } \\
\text { papel } & \text { técnico } \\
\text { dos } & \\
\text { coordenadores } \\
\text { do } \quad \text { distrito } \\
\text { sanitário } & \end{array}$ & $\begin{array}{l}\text { Ainda tá muito indefinido o papel } \\
\text { de cada um de nós, dentro deste } \\
\text { processo de municipalização, aqui } \\
\text { na geréncia do distrito. }\end{array}$ & $\begin{array}{|ll|}\text { Membros } & \text { da } \\
\text { Coordenação } & \text { do } \\
\text { DSBRV } & \end{array}$ & $\begin{array}{|lr|}\text { Negativo: } & \\
\text { Indefiniçăo r de } \\
\text { papéis } & \text { dos } \\
\text { coordenadores } & \\
\end{array}$ \\
\hline $\begin{array}{lr}\text { Impacto } & \text { no } \\
\text { papel } & \text { dos } \\
\text { Conselhos } & \text { de } \\
\text { Saúde } & \end{array}$ & $\begin{array}{l}\text { O conselho, como tem } \\
\text { representante da comunidade, eu } \\
\text { acho que ele ganha força. Esses } \\
\text { conselhos, vocé sabe que já } \\
\text { existiu, vocé sabe né, um tempo } \\
\text { atrás. Anos atrás. Aí, tiraram } \\
\text { acabou...E agora com a } \\
\text { municipalizaçăo retoma tudo de } \\
\text { novo. Eu acho que é a única } \\
\text { maneira que a gente vai conseguir } \\
\text { muita coisa. Interesse deles e } \\
\text { interesse nosso. Eles estăo } \\
\text { gritando. Eles junto com o } \\
\text { Conselho Municipal văo } \\
\text { conseguir. }\end{array}$ & $\begin{array}{l}\text { Trabalhadores da } \\
\text { Saúde }\end{array}$ & $\begin{array}{|lr|}\text { Positivo: } & \\
\text { Fortalecimento } & \text { da } \\
\text { atuaçăo } & \text { dos } \\
\text { conselhos de saúde }\end{array}$ \\
\hline
\end{tabular}


O impacto do processo de municipalização sobre o fortalecimento do papel tanto do distrito sanitário quanto dos conselhos locais é um fato. No entanto isso é percebido e valorado como positivo apenas pelos trabalhadores da saúde, alguns com funçōes de coordenação no DSBRV. Não houve identificação de unidades de análise diretamente relacionadas com a municipalizaçāo nos grupos focais realizados tanto com usuários dos serviços de saúde quanto com conselheiros representantes da comunidade. No caso desses últimos, muitas das enunciações possuiam interface com o tema e, portanto, demonstravam algum grau de conhecimento mas não a incorporação da palavra "municipalização" ao seu vocabulário.

Já a ausência de referências direta pode refletir o pouco conhecimento da política em curso, o que parece ser o caso dos usuários, e a importância relativa ou mesmo pouca importância da municipalização nas análises e reflexões discutidas pelos conselheiros de saúde em relação à gestão no distrito sanitário. Este significado parece coerente com os achados identificados como inovadores no modo de conduzir a gestão da saúde por esses mesmos atores, analisados posteriormente (ver Seção 5). 
Quadro 5 - Impacto da municipalizaçāo no gerenciamento do DSBRV

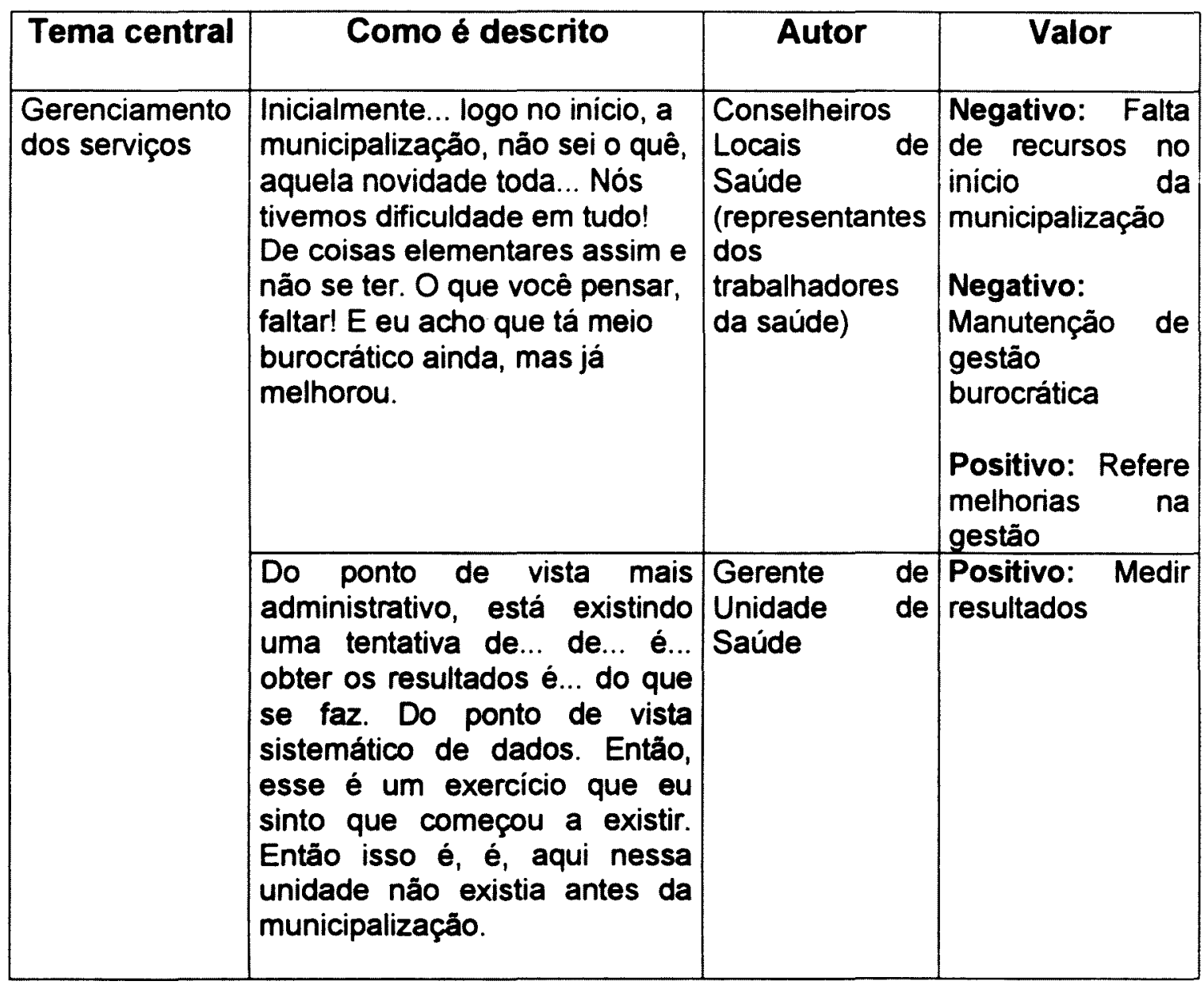

O tema central no Quadro 5 está diretamente relacionado com uma das diretrizes do Plano Municipal da Saúde 1998/2001, reorganização do modelo de gestão e reorganização do modelo de atenção (SECRETARIA MUNICIPAL DA SAÚDE DE SALVADOR 1997a). Em geral, as descrições do tema revelam aspectos afirmativos na operacionalização dessa diretriz, ainda que não tenha sido possivel identificar exemplos concretos dos aspectos positivos identificados no modelo de gestão a exemplo da mensuração de resultados. Mais uma vez estes aspectos positivos, ainda que vagos, são identificados apenas por profissionais da saúde. 
Quadro 6 - Influẻncia da municipalização quanto à disponibilidade de recursos

\begin{tabular}{|c|c|c|c|}
\hline Tema central & Como é descrito & Autor & Valor \\
\hline \multirow[t]{2}{*}{$\begin{array}{l}\text { Recursos } \\
\text { materiais } \\
\text { equipamentos }\end{array}$} & $\begin{array}{l}\text { Que está mais fácil agora, com a municipalizaçăo, apesar dessa desorganizaçảo toda, de } \\
\text { mudança, tá sim. Já se consegue uma série de coisas, que antes nåo se conseguia na } \\
\text { SESAB. Em termos de material, de equipamento. }\end{array}$ & \begin{tabular}{ll|} 
Membro & da \\
Coordenaçăo do & \\
DSBRV
\end{tabular} & $\begin{array}{l}\text { Positivo: Maior volume de } \\
\text { recursos materiais } \\
\text { Negativo: Desorganizaçåo }\end{array}$ \\
\hline & $\begin{array}{l}\text { Agora, na atual conjuntura tá muito pior. Tem um limite, tem um limite né? Aqui na unidade } \\
\text { de saúde as mínimas coisas a gente năo tem, né? Entăo eu acho que está péssimo... e eu } \\
\text { tinha a esperança que, com a municipalizaçăo, fosse melhorar, o na verdade nåo } \\
\text { melhorou... }\end{array}$ & $\begin{array}{l}\text { Trabalhadores da } \\
\text { Saúde }\end{array}$ & $\begin{array}{l}\text { Negativo: Falta de recursos } \\
\text { materiais mínimos }\end{array}$ \\
\hline $\begin{array}{l}\text { Recursos } \\
\text { financeiros }\end{array}$ & $\begin{array}{l}\text { O municlpio passou a receber mais recursos com a municipalizaçăo, mas, no entanto, o que } \\
\text { a gente tem visto é uma grande precariedade nas unidades de saúde, na prestaçăo de } \\
\text { serviços de saúde. }\end{array}$ & \multirow[t]{2}{*}{$\begin{array}{l}\text { Membros do } \\
\text { CMS }\end{array}$} & $\begin{array}{l}\text { Positivo: Maior volume de } \\
\text { recursos financeiros } \\
\text { Negativo: Prestaçăo de serviços } \\
\text { de baixa qualidade }\end{array}$ \\
\hline $\begin{array}{l}\text { Recursos } \\
\text { humanos }\end{array}$ & $\begin{array}{l}\text { Agora, eu năo tó aqui na defesa da secretaria municipal da saúde, mas é muito ruim você } \\
\text { pegar um sistema, que era de } 19 \text { unidades, para } 84 \text {, subiu. Com esses problemas todos e a } \\
\text { Secretaria de Saúde do Estado, no processo de municipalizaçăo, ela ficou isenta. Ela se } \\
\text { considerou isenta. Só desceu os recursos humanos, né, da pior forma possível, sem } \\
\text { aumento (de salário), pessoal sem reciclagem; sem discutir o processo desse novo } \\
\text { gerenciamento (...). }\end{array}$ & & $\begin{array}{l}\text { Positivo: Aumenta o número de } \\
\text { unidades de saúde e de } \\
\text { servidores } \\
\text { Negativo: } \\
\begin{array}{l}\text { despreparados e com baixos } \\
\text { salários }\end{array}\end{array}$ \\
\hline
\end{tabular}


O Quadro 6, cujo tema central refere-se à disponibilidade de recursos no distrito sanitário, tem relação com as diretrizes reorganização do modelo de atenção e desenvolvimento de recursos humanos. Nos temas selecionados identifica-se que a operacionalização de tais diretrizes aponta para um desempenho precário, ainda que se reconheça que o processo de municipalização aumentou o aporte de recursos para a SMS e mesmo possibilitou o aumento dos quadros de pessoal no distrito com a alocação dos servidores públicos do estado. No entanto, há várias outras referências negativas em relação à administração de pessoal, ditas e observadas, principalmente os remanejamentos constantes dentro do território do distrito; a inexistência de definição de um quadro de pessoal para cada unidade de saúde; a manutenção das diferenças salariais entre os servidores e a inexistência de uma política de pessoal definida. Um aspecto contraditório aparece na descrição divergente entre membros da coordenação do distrito sanitário e trabalhadores da saúde quanto à disponibilidade de recursos materiais.

A partir destes achados e também com base nas observações realizadas posso apontar algumas considerações sobre a municipalização na prática do Distrito Sanitário Barra/Rio Vermelho:

- A descentralização das ações e serviços de saúde não foi acompanhado nem de maior poder de decisão neste âmbito nem tampouco de maiores (e ouso dizer melhores) recursos, tanto para a prestação das ações quanto para a gestão do sistema local;

- As observações permitem também uma constatação de que ainda que seja assumida formalmente pelo poder executivo municipal, a municipalização enquanto politica se ressente de uma execução eficiente enquanto política e da inexistência de aspectos democráticos na condução da gestão local. 


\section{INOVAÇÃO E GESTÃO EM SAÚDE: O CASO DO DISTRITO SANITÁRIO BARRARIO VERMELHO, SALVADOR}

\subsection{Premissas}

Este capítulo descreve e analisa os achados do estudo de caso tendo como contexto os elementos externos já apresentados e discutidos anteriormente. Num momento inicial estão analisados o cotidiano do Distrito Sanitário Barra/Rio Vermelho e o processo de gestão. Posteriormente apresento a definição de inovação elaborada a partir de todas as entrevistas e grupos focais realizados no trabalho de campo e apresento e analiso as inovações identificadas.

Os achados coletados e relacionados com as possíveis inovações foram analisados com a utilização do software Q.S.R. NUD.IST4 (QUALITATIVE SOLUTIONS AND RESEARCH PTY LTD 1997). Nesta pré-análise foram identificados, separados e codificados em unidades de análise por categorias. As categorias, destacadas inicialmente através de uma leitura flutuante dos achados, foram identificadas a partir do tema central das unidades de análise. Essas categorias prévias foram revistas à medida que eram introduzidas no banco de dados qualitativo e organizadas numa árvore composta por nós (ver Figura 2, p. 57), cada um composto de um bloco de unidades de texto agregando a definição da palavra "inovação" e exemplos em que se identificavam as inovações. O segundo nó se dividia em subnós contendo as inovaçōes identificadas. Os nós e subnós foram utilizados como categorias para a análise e direcionaram a apresentação dos achados. 


\subsection{O cotidiano no Distrito Sanitário Barra/Rio Vermelho}

A vida cotidiana, considerada como uma das esferas heterogêneas da estrutura social, é aqui tomada como representativa em sua condução, principalmente quanto ao seu aspecto de desabafo e de caráter excepcional, capaz de transformar a ordenação da cotidianidade em uma ação com caracteristicas políticas. Isto significa que, mesmo em condições gerais que favoreçam a alienação, a condução na vida cotidiana é capaz de produzir alguma transformação, ou ao menos alguma provocação, à ordem estabelecida (HELLER 2000, p. 41).

O interesse pelo cotidiano da gestão busca identificar nesse espaço um ponto de referência de novas possibilidades no modo de conduzir a saúde no âmbito local e numa realidade especifica. Isto porque nesse "pequeno mundo de todos os dias está também o tempo e o lugar da eficácia das vontades individuais, daquilo que faz a força da sociedade civil, dos movimentos sociais" (MARTINS 1998, p. 2). Deste modo considero que as relações no cotidiano são capazes de iluminar criativamente o modo de gerir a saúde no Brasil, dado que são permeadas de rupturas que permitem o aparecimento do inovador e da transgressão. É com essa crença que devem ser lidos criticamente os achados relacionados a seguir.

Tomando em conta um dos referenciais teórico-metodológicos utilizados no estudo do caso, a etnometodologia (GARFINKEL e SACKS 1995; COULON 1996), as informaçōes coletadas sobre o cotidiano no DSBRV serão apresentadas com base na interpretação dada pelos atores para a experiência cotidiana vivida no processo de gerir um distrito sanitário, uma vez que esta interpretação é constituinte do mundo social. A partir de algumas expressõeschave utilizadas na abordagem etnometodológica (ação humana, crenças e reflexividade) e a síntese de unidades de análise selecionadas nos achados 
tentei responder à pergunta: "O que eu faço no meu dia-a-dia?".

As atividades destacadas pelos membros da coordenação do DSBRV estão voltadas fundamentalmente para a resposta cartorial e burocrática às demandas que chegam à coordenação, com ênfase para o atendimento às solicitaçōes do nivel central da SMS. Reuniões (muitas sem planejamento prévio), visitas às unidades de saúde, encaminhamentos de documentos e atender ligações telefônicas são as mais freqüentes.

Neste cenário, as crenças expressadas pelos membros da coordenação do DSBRV revelam claramente a forte submissão do papel atribuído ao distrito frente ao nível central da SMS, especialmente à figura da secretária. São exemplos declarações como: "minha função é responder às demandas da secretária da saúde" ou "nós somos os olhos e ouvidos da secretária".

Em alguns momentos de auto-reflexão pode ser identificado que existe uma não-aceitação do papel atribuído à coordenação quando se afirma que "somos muito cerceados" e de reconhecimento crítico deste mesmo papel nas declaraçōes "(...) nós somos os bombril (sic) do distrito" e "a gente não consegue trabalhar em equipe".

Para os gerentes de unidades de saúde as atividades cotidianas mais freqüentes não diferem muito do que foi identificado pelos membros da coordenação do DSBRV. Em particular dedicam grande parte do tempo em resolver demandas circunstanciais (falta de material de consumo; marcação de consultas, atendimento de usuários substituindo um colega faltoso ao serviço, etc.); com a administração de pessoal (verificação dos ausentes; entrega de atestados, remanejamentos); reuniões (em particular as reuniões com os conselhos locais de saúde foram sempre referidas por todos os entrevistados) e atividades cartoriais. 
Os depoimentos indicam sentimentos de impotência com a situação vivida como "eu me sinto impotente e tô vendo que não adianta"; "quer dizer, fico tentando... aquela estória de casa de ninguém, né. Tentando cobrir tudo, né" e de incompreensão frente à manutenção das condiçōes precárias de trabalho e de organização dos serviços como em "regularizar certas demandas não é tão complicado. A máquina tem que funcionar melhor entendeu?" $E$ "eu acho que, o que me sobressai, que... é..., a gente não deveria mais estar trabalhando para sobreviver. (...) Quando eu digo trabalhando pra sobreviver é trabalhando pra ter agora, é trabalhando pra ter água pra beber, sabe? É trabalhando pra ter medicação básica na farmácia; o corante pra fazer o hemograma".

No entanto, registre-se o reconhecimento, numa situação considerada como caótica, dos méritos de alguns trabalhadores que "fazem o dia-a-dia" funcionar apesar de tudo: "Mas aqui (refere-se à unidade de saúde que gerencia) eu tenho não é um nem dois não, são muitos (refere-se aos trabalhadores na unidade). Que eu sinto que é eles que fazem o cotidiano sozinhos mesmo. Movimentam sozinhos o dia-a-dia. E a nivel de grupo também, a influência que eles têm no serviço, no grupo".

Quanto aos trabalhadores da saúde, as atividades destacadas se referem ao atendimento da demanda em programas de saúde implantados, atividades "educativas" com grupos da população e reuniões.

As crenças expressadas em relação ao trabalho desenvolvido quase sempre indicam desmotivação e o agravamento das condições de vida dos trabalhadores, principalmente os de escolaridade média: "Eu mesmo vou fazendo metodicamente. Os programas vém, sem conhecimento, sem que a gente tenha interesse de fazer aquele programa" e "um funcionário público já tá 
chegando num ponto que ele tá estressado. Eu tenho colegas que tem dias que não tão indo trabalhar porque não agüenta; porque o salário não dá... não tem dinheiro pra transporte; não tem nada pra se alimentar".

Nos momentos de auto-reflexão atribuem a desmotivação no trabalho à desorganização dos serviços: "às vezes eu fico aqui no posto e a conclusão que eu chego é que é uma confusão. Para mim as coisas têm que ter um início, tém que ter um processo, têm que ter um fim, tem que acompanhar" e à piora nas condições de trabalho: "Se a gente tem compromisso com o trabalho da gente, a gente faz. Mas pior do que nós estamos agora nunca teve".

No entanto, existe o reconhecimento de que a própria desorganização institucional permite, contraditoriamente, certo grau de autonomia na condução das ações pelos trabalhadores de saúde interessados em agir: "Eu comecei a perceber que não era bem assim. Que as coisas aconteciam de acordo com a vontade da gente em fazer. Por exemplo: se eu quero ir pra escola fazer programa de saúde bucal, eu the digo que quero e vou".

Desse modo, como parte orgânica da vida no cotidiano, a organização do trabalho, quando em prática, revela graus de submissão e de liberdade. No entanto, identificamos também que entre os trabalhadores não há um exercício pleno da sua cotidianidade, o que significa, por sua vez, um não amadurecimento das habilidades imprescindiveis do fazer o cotidiano como possibilidade de transformação ou transgressão (HELLER 2000, p. 19), refletida na declaração: "Já se reivindicou muito, já se batalhou muito, já se fez muito. $E$ o que foi que a gente teve de retorno? Coisa nenhuma. Então chegou num momento que as pessoas estão se retraindo cada vez mais, o que é natural do ser humano". 
Mesmo com tal situação, nos relatos sobre o cotidiano de trabalho os atores levantaram algumas táticas utilizadas no dia-a-dia, visando burlar, de modo positivo, as barreiras encontradas para a realização do próprio trabalho, mesmo num contexto desfavorável:

- Não execução de normas e fluxos estabelecidos pelos niveis central e local com o objetivo de realizar o trabalho que consideram necessário/relevante;

- Priorizar, internamente, trabalhos de caráter participativo/educativo com grupos e atividades realizadas fora das unidades de saúde;

- Introduzir pequenas modificações nas atividades programadas verticalmente pela SMS, visando atender as necessidades locais;

- Apoiar profissionais com uma prática voltada às necessidades locais e com uma "visão mais política";

- Busca de maior articulação no trabalho com outros profissionais; com a população e com agentes comunitários de saúde, além de com outras instituições.

\subsection{A gestão em saúde no Distrito Sanitário Barra/Rio Vermelho}

O processo de gestão no DSBRV é apresentado e analisado através do destaque de características extraídas das unidades de análise processadas previamente. Buscou-se extrair cada uma das características da própria fala dos informantes e manter a descrição feita por eles próprios. 
Quadro 7-A Gestão no DSBRV: Autoritária e Centralizadora

\begin{tabular}{|c|c|c|}
\hline Como é descrita & Autor & $\begin{array}{l}\text { Qualificadores } \\
\text { identificados }\end{array}$ \\
\hline $\begin{array}{l}\text { Porque está instituído uma política do coronelato } \\
\text { (risos). Como é isso? A política do coronelato, quem } \\
\text { for de encontro ao poder maior, que a gente sabe } \\
\text { quem é, não precisa dizer nomes, o poder maior que } \\
\text { é, esse dai, já sabe, né, digamos que é banido, } \\
\text { perseguido. }\end{array}$ & $\begin{array}{ll}\text { Trabalhadores } & \text { da } \\
\text { Sauide } & \end{array}$ & $\begin{array}{l}\text { Política do coronelato } \\
\text { (sic) }\end{array}$ \\
\hline $\begin{array}{l}\text { Tem clientelismo, algumas chefes de unidades agora } \\
\text { são irmãs do pessoal do nivel central. Ou então a } \\
\text { partir do dientelismo, fisiologismo. Tudo isso está } \\
\text { instalado É "coronelismo". Gerência do "coronelismo". } \\
\text { Tá instalada no distrito. Com poucos, poucas ilhas } \\
\text { de, de, independentes. Poucas, muito poucas. }\end{array}$ & & Clientelista/fisiologista \\
\hline $\begin{array}{l}\text { A geréncia, hoje, é uma gerência de cooptaçāo, de } \\
\text { coerção. (...). A gente (refere-se aos trabalhadores da } \\
\text { saúde) está sendo muito fiscalizado, observado. Eu } \\
\text { caracterizo essa gestão como centralizadora, } \\
\text { autoritária. }\end{array}$ & & Cooptação e coerção \\
\hline $\begin{array}{l}\text { Aí a gente vai ver as interferências que vêm, vertical, } \\
\text { de cima para baixo. (...) às vezes vem uma imposição } \\
\text { de fora e aí você percebe que você não tem } \\
\text { autoridade nenhuma para decidir nada. }\end{array}$ & \begin{tabular}{|ll} 
Membros & da \\
coordenação & do \\
DSBRV &
\end{tabular} & Não-autônoma \\
\hline $\begin{array}{l}\text { A secretária disse várias vezes aos coordenadores } \\
\text { de distritos em reuniōes na secretaria que "vocés são } \\
\text { meus olhos e ouvidos. Quando vocés falam, sou eu } \\
\text { quem falo". }\end{array}$ & & \begin{tabular}{|l} 
Fiscalizadora \\
\end{tabular} \\
\hline
\end{tabular}


Qualificada como clientelista, centralizadora, coercitiva e fiscalizadora a condução da gestão pela coordenação do DSBRV se ressente, por sua vez, da falta de maior autonomia para a tomada de decisão frente ao nivel central da SMS. A falta de informação e a ausência de participação em qualquer processo ou decisão são sempre referidas, principalmente pelos trabalhadores da saúde. São também freqüentes as referéncias ao não encaminhamento de decisōes, bem como a ausência de retorno às demandas, seja das unidades de saúde, seja dos conselhos locais de saúde.

Tais características do processo de gestão no DSBRV reforçam os elementos analisados anteriormente, em que a municipalização dos serviços e ações de saúde em Salvador traz em seu bojo um aspecto contraditório aos princípios intrínsecos a essa dinámica, que seria a de propiciar a autonomia e o poder local na gestão da saúde em territórios microlocalizados. Isto justifica o "tom" de decepção com que os atores locais referem-se ao processo de municipalização, diretamente relacionado e às vezes responsabilizado pelo caráter autoritário da gestão local.

\subsubsection{Perfil do gestor institucional}

$\mathrm{Na}$ caracterização do modo de gestão do distrito sanitário surgiram espontaneamente descrições que se referem ao perfil dos gestores institucionais locais. Num primeiro momento foram construídos quadros analíticos por autoria, que foram sintetizados considerando apenas os qualificadores diferentes entre si. $O$ qualificador mais freqüente encontrado foi a não qualificação/capacidade para o desempenho da função gerencial. 
Considerando que este aspecto complementa a compreensão do processo de gestão no DSBRV, o Quadro 8 descreve este perfil e identifica os qualificadores utilizados nessa descrição. 


\begin{tabular}{|c|c|c|}
\hline Como é descrito & $\begin{array}{l}\text { Qualificadores } \\
\text { identificados }\end{array}$ & Autor \\
\hline $\begin{array}{l}\text { (...), a nlvel de geréncia de distrito, eu de fato acho que faltam pessoas, qualificadas. N6́s năo temos nenhum treinamento pra uma série de } \\
\text { coisas que a gente tem que desenvolver. A gente faz as coisas muito empiricamente, sabe? }\end{array}$ & Sem qualificaçăo & \multirow[t]{2}{*}{$\begin{array}{ll}\text { Membros } & \text { da } \\
\text { Coordenaçaso do } & \text { do } \\
\text { DSBRV }\end{array}$} \\
\hline (...). E por isso que eu digo que eu me considero uma tarefeira. & "Tarefeira" & \\
\hline $\begin{array}{l}\text { Eu acho assim, que a dificuldade no distrito, que os outros gerentes possam ter, é que eu tive o privilígio, né, de já trabalhar há muito tempo, de } \\
\text { já estar aqui dentro há muito tempo, da saúde pública, e ter trabalhado com pessoas também capacitadas. (...). Agora, eu fico preocupada } \\
\text { assim, poxa, como eles (relere-se aos colegas gerentes) estăo se saindo? (...). Porque eu jâ aprendi leso, al eu fico preocupada assim, como } \\
\text { eles văo fazer isso, se eles năo sabern? }\end{array}$ & Sem conhecimento & \multirow[t]{2}{*}{\begin{tabular}{|ll} 
Gerentes & de \\
Unidades & de \\
Saúde &
\end{tabular}} \\
\hline $\begin{array}{l}\text { Quando eu cheguel aqui, alids, antes de vir praqui, ful convidada umas trés vezes, mas fiquel receosa de assumir, porque eu achava que nåo } \\
\text { tava preparada. (...). Da terceira vez, ai foi assim imposto: "vai ter que ir mesmo". Eu vim, morrendo de medo (ri). }\end{array}$ & Inexperiente & \\
\hline $\begin{array}{l}\text { (...) esse negócio de vocé ir pra os cargos por capacidade isso é besteira, entendeu? Pra eles leso năo interessa, o que interessa é que vocé } \\
\text { seja uma pessoa que esteja ali pra dizer amém, amém, amém. }\end{array}$ & Submisso & \multirow[t]{2}{*}{$\begin{array}{l}\text { Trabalhadores da } \\
\text { Saude }\end{array}$} \\
\hline $\begin{array}{l}\text { As pessoas năo têm informaçăo nessa área gerencial. Năo tém capacidade de dirigir uma reuniâo, năo tém capacidade de trabalhar com } \\
\text { planejamento, com negociaçăo, técnicas de negociaçăo. De, simples, é, dado sobre desenvolvimento de recursos humanos, de remanejamento } \\
\text { de pessoal, de, de tudo. Năo, năo tem. (...). Acho que năo há um interesse que haja uma geréncia capacitada, năo há interesse nisso năo. }\end{array}$ & Sem qualificaçăo & \\
\hline $\begin{array}{l}\text { E os gerentes que eståo assumindo săo muitos incompetentes! Pessoas que salram da assisténcia para gerenciar um distrito sem nenhum } \\
\text { preparo! }\end{array}$ & Incompetente & Membro do CMS \\
\hline $\begin{array}{l}\text { O posto aqui, todas as diretoras que vém pro Posto, elas já vêm com medo. Porque ela sabe, se ela nắo andar na linha, ela perde o cargo dela. } \\
\text { Isso já aconteceu com cinco seguidas, certo? Năo atendeu as exigéncias que a gente pediu, "a gente quer assim". A última mesmo, (...) } \\
\text { mandava representar porque ela năo tinha pelto pra enfrentar a comunidade. E sempre mandava uma desculpa que isso, que aquilo e tal. }\end{array}$ & $\begin{array}{l}\text { Sem habilidade para } \\
\text { se relacionar com a } \\
\text { comunidade }\end{array}$ & \multirow[t]{2}{*}{ Usuários } \\
\hline $\begin{array}{l}\text { Cada um gerente que vem pro posto de saúde, eu vejo isso, apesar de năo andar multo em posto de saúde, agora é que eu tó me envolvendo } \\
\text { mais nessa coisa de saúde. É, o gerente que vem pro posto eles tăo vindo mais empenhado em melhorar aquele posto, aquele ambiente de } \\
\text { trabalho. Entăo isso, positivamente, vai trazer melhoria pra gente. }\end{array}$ & Mals empenhado & \\
\hline
\end{tabular}


Analisando o Quadro 8, percebe-se que $\circ$ os próprios gestores institucionais se reconhecem como despreparados para assumir as funções que desenvolvem. Suas enunciações são quase sempre sóbrias, de onde podemos inferir um compromisso com o que afirmam.

Um aspecto interessante é que, enquanto as descrições feitas pelos membros da coordenação do distrito sanitário tém uma forma direta e auto-referida, um gerente de unidade de saúde refere-se negativamente sobre o preparo dos colegas para o desempenho da função mas deixa claro um álibi quanto à sua própria capacidade, tentando assim "resolver" a contradição entre o que afirma sobre os seus pares e o seu desempenho.

Ainda que o perfil dos gestores institucionais seja descrito com qualificadores sempre negativos, reforçados inclusive pela troca freqüente de gerentes das unidades de saúde no distrito estudado, registrado também durante o período de trabalho de campo, foi possível destacar um aspecto positivo, descrito pelos usuários. No entanto, tal aspecto é referido num contexto mais amplo, que precisa ser explicado. Os usuários neste grupo focal tinham como referência uma microárea do DSBRV, onde se situa um dos centros de saúde. Nessa área, a mobilização da população através de suas associações de moradores e do conselho local de saúde tem conseguido, ao longo dos anos, intervir no sentido de demitir gerentes considerados inadequados pela população local. Desse modo, essa área possui uma experiéncia acumulada que permite aos autores identificar um perfil positivo do gestor local, isto é, maior compromisso na melhoria dos serviços oferecidos. Podemos inferir de tal fato que há um maior "cuidado" da SMS em nomear profissionais para gerir essa unidade de saúde em particular. Tal resultado pode ser considerado como fruto do próprio processo de mobilização existente nesta área. 


\subsubsection{Avaliação da gestão em saúde}

Através da técnica de análise de avaliação (BARDIN 1977) adaptada ao contexto da investigação, apresentamos nos Quadros 9 e 10 os resultados da avaliação sobre a gestão do DSBRV. Os quadrossíntese foram construídos a partir dos dois objetos de atitude mais freqüentes: capacidade de gestão e autonomia do DSBRV e controle social.

$\mathrm{Na}$ última coluna encontram-se os resultados da análise avaliativa valoradas como positivas ou negativas em relação aos aspectos de qualidade ou desempenho, quando existentes na enunciação. 
Quadro 9 - Análise avaliativa da capacidade e autonomia de gestão no DSBRV, 1999

\begin{tabular}{|c|c|c|c|c|c|}
\hline Autor & Como é descrita & $\begin{array}{l}\text { Objeto de } \\
\text { atitude }\end{array}$ & Conector verbal & $\begin{array}{c}\text { Termo } \\
\text { avaliativo }\end{array}$ & $\begin{array}{c}\text { Resultado da } \\
\text { avaliaçăo }\end{array}$ \\
\hline $\begin{array}{l}\text { Membro } \\
\text { da Coordenação } \\
\text { do DSBRV }\end{array}$ & $\begin{array}{l}\text { Que nós temos valor atualmente, como gerência, temos. Que a } \\
\text { gente resolve problemas das unidades? Não todos, mas se } \\
\text { consegue, se resolve alguma coisa. Se consegue dar } \\
\text { encaminhamento a uma série de coisas que antes não se } \\
\text { conseguia. }\end{array}$ & $\begin{array}{l}\text { Capacidade } \\
\text { de gestão }\end{array}$ & $\begin{array}{l}\text { Temos } \\
\text { Resolve } \\
\text { Consegue }\end{array}$ & $\begin{array}{l}\text { Valor como } \\
\text { gerência } \\
\text { Problemas } \\
\text { das unidades }\end{array}$ & $\begin{array}{l}\text { Qualidade } \\
\text { positiva } \\
\text { Desempenho } \\
\text { positivo }\end{array}$ \\
\hline $\begin{array}{l}\text { Gerente } \\
\text { de Unidade de } \\
\text { Saúde }\end{array}$ & $\begin{array}{l}\text { (...). Segundo a secretária da saúde, aqui é questão de tempo, } \\
\text { mas o distrito realmente não é gestor; o distrito continua ligado } \\
\text { diretamente à secretaria municipal. Quer dizer, não tem } \\
\text { nenhuma autonomia e aí fica a secretaria, o distrito. (...). A } \\
\text { gente (refere-se às unidades de saúde) repassa pro distrito. O } \\
\text { distrito por sua vez também, não tem autonomia, aí tem que } \\
\text { aguardar e repassar pra secretaria, aí fica aquela cadeia, aí eu } \\
\text { acho que isso foi entrave... }\end{array}$ & \begin{tabular}{|l|} 
Autonomia e \\
capacidade \\
de gestão
\end{tabular} & $\begin{array}{l}\text { Continua } \\
\text { Não Tem }\end{array}$ & $\begin{array}{l}\text { Ligado à } \\
\text { secretaria } \\
\text { municipal } \\
\text { Autonomia }\end{array}$ & $\begin{array}{l}\text { Qualidade } \\
\text { negativa } \\
\text { Desempenho } \\
\text { negativo }\end{array}$ \\
\hline
\end{tabular}


Quadro 9-Análise avaliativa da capacidade e autonomia de gestão no DSBRV, 1999, continuação

\begin{tabular}{|c|c|c|c|c|c|}
\hline Autor & Como é descrita & $\begin{array}{l}\text { Objeto de } \\
\text { atitude }\end{array}$ & Conector verbal & Termo avaliativo & $\begin{array}{c}\text { Resultado da } \\
\text { avaliaçăo }\end{array}$ \\
\hline Membro do CMS & $\begin{array}{l}\text { A gente não percebe, não percebe nenhum esforço no } \\
\text { sentido de que o distrito sanitário, de que tenha, tenha } \\
\text { algum nível de autonomia, tenha algum nivel de decisão } \\
\text { do ponto de vista do planejamento das ações. (...). } \\
\text { Atualmente o que a gente vê é um cerceamento total, } \\
\text { uma apatia e uma espera das ordens da secretária (bate } \\
\text { na mesa, tom de raiva), as ordens da secretária. }\end{array}$ & Autonomia & $\begin{array}{l}\text { Percebe } \\
\text { É }\end{array}$ & $\begin{array}{l}\text { Nenhum esforço } \\
\text { Cerceamento total } \\
\text { Espera por ordens }\end{array}$ & $\begin{array}{l}\text { Qualidade } \\
\text { negativa } \\
\text { Desempenho } \\
\text { negativo }\end{array}$ \\
\hline $\begin{array}{l}\text { Trabalhadores } \\
\text { da Saúde }\end{array}$ & $\begin{array}{l}\text { Eu acho que há uma desorganização total de } \\
\text { administração (refere-se à coordenação do DSBRV)... } \\
\text { péssima... pra mim, é péssima, isso que eu tô vendo. A } \\
\text { administração é péssima. }\end{array}$ & $\begin{array}{l}\text { Capacidade } \\
\text { de gestão da } \\
\text { coordenação } \\
\text { do DSBRV }\end{array}$ & Há & $\begin{array}{l}\text { Desorganização } \\
\text { total } \\
\text { Péssima }\end{array}$ & $\begin{array}{l}\text { Desempenho } \\
\text { negativo } \\
\text { Qualidade } \\
\text { negativa }\end{array}$ \\
\hline $\begin{array}{l}\text { Conselheiros da } \\
\text { Saúde } \\
\text { (representantes } \\
\text { da comunidade) }\end{array}$ & $\begin{array}{l}\text { (...) porque quando o UNI (refere-se ao Projeto UNI/BA) } \\
\text { tá nessa pressão, nessa negociação, tal, as coisas } \\
\text { andam; quando não tá, a coisa parece que... não sabe o } \\
\text { rumo que vai, não sabe... não há gerência, não há gestão. }\end{array}$ & $\begin{array}{l}\text { Capacidade } \\
\text { de gestão }\end{array}$ & $\begin{array}{l}\text { Está } \\
\text { Sabe } \\
\text { (Não) Há }\end{array}$ & $\begin{array}{l}\text { Na pressão } \\
\text { Não (sabe) o rumo } \\
\text { Gerência }\end{array}$ & $\begin{array}{l}\text { Qualidade } \\
\text { negativa } \\
\text { Desempenho } \\
\text { negativo }\end{array}$ \\
\hline
\end{tabular}


Quadro 10 - Análise avaliativa do controle social na gestão do DSBRV, 1999

\begin{tabular}{|c|c|c|c|c|c|}
\hline Autor & Como é descrita & $\begin{array}{c}\text { Objeto de } \\
\text { attude }\end{array}$ & $\begin{array}{c}\text { Conector } \\
\text { verbal }\end{array}$ & $\begin{array}{c}\text { Termo } \\
\text { avaliativo }\end{array}$ & $\begin{array}{c}\text { Resultado da } \\
\text { avallação }\end{array}$ \\
\hline Membro do CMS & $\begin{array}{l}\text { E eu vejo, com essa visáo, essa experiência de vinte anos, um } \\
\text { avanço com a nova gestão no serviço municipal de saúde; no } \\
\text { sistema municipal de saúde em particular. Porque, a volta da } \\
\text { organizaçäo dos trabalhadores junto com a comunidade, ela resolve } \\
\text { um impasse, de algum tempo, que ó exatamente aquele atrito que } \\
\text { existia entre os profissionais de saúde e a própria comunidade. O } \\
\text { conselho local de saúde, ele também tem essa caracteristica. E } \\
\text { acima de tudo o controle social, sobre as açoses de saúde, naquele } \\
\text { distrito ali. }\end{array}$ & \begin{tabular}{|lr} 
Retorno & da \\
organizagaão & dos \\
trabalhadores & $\bullet$ \\
comunidade &
\end{tabular} & $\begin{array}{l}\text { Vejo } \\
\text { Volta }\end{array}$ & $\begin{array}{l}\text { Avanço } \\
\text { Organização } \\
\text { Controle social }\end{array}$ & $\begin{array}{l}\text { Qualidade positiva } \\
\text { Desempenho positivo }\end{array}$ \\
\hline $\begin{array}{l}\text { Conselheiros Locais } \\
\text { de Saúde } \\
\text { (representantes da } \\
\text { comunidade) }\end{array}$ & $\begin{array}{l}\text { Năo sei se pela pressáo, mas eu acho que é uma coisa inovadora } \\
\text { esta questão de, tem os Conselhos que a gente sabe que năo é uma } \\
\text { coisa assim, que não é uma coisa à-toa, mas, de repente, também } \\
\text { eles estão ouvindo, tão, assim, abrindo um pouco pros problemas e } \\
\text { tão ouvindo as pessoas (...). Onde eles querem chegar não dá para } \\
\text { identificar, mas eu acho que eles estão ouvindo. De um jeito ou de } \\
\text { outro, mesmo com a pressão, mas tâ ouvindo. }\end{array}$ & $\begin{array}{l}\text { Escuta, pelos } \\
\text { dirigentes, dos } \\
\text { problemas } \\
\text { apresentados } \\
\text { pelos conselhos } \\
\text { locais de saúde }\end{array}$ & Sei & $\begin{array}{l}\text { Pela pressáo } \\
\text { Ouvindo } \\
\text { pessoas }\end{array}$ & $\begin{array}{l}\text { Qualidade negativa } \\
\text { Desempenho positivo }\end{array}$ \\
\hline $\begin{array}{l}\text { Trabalhadores da } \\
\text { Saúde }\end{array}$ & $\begin{array}{l}\text { E a gestăo do serviço, do distrito em relaçăo ao conselho local, ficou } \\
\text { respondendo à demanda, nó. Näo houve avanço em termos de } \\
\text { interlocução maior com os conselhos locais, em termos de } \\
\text { gerenciamento. Com participação da comunidade na gestão do } \\
\text { distrito. }\end{array}$ & $\begin{array}{l}\text { Interlocuçăo entre } \\
\text { CLS } \times \text { gestores }\end{array}$ & (Náo) Houve & Sem avanços & $\begin{array}{l}\text { Desempenho } \\
\text { negativo }\end{array}$ \\
\hline
\end{tabular}


Os resultados indicam um balanço desfavorável na avaliação realizada quanto à capacidade de gestão no DSBRV, nos aspectos de qualidade e principalmente quanto ao desempenho.

Num balanço final a avaliação da capacidade de gestão é positiva apenas para membros da Coordenação do DSBRV. A significáncia desta avaliação é relevante dado que foi feita por quase a totalidade dos atores locais (com exceção dos usuários, que não expressam avaliação em relação a este objeto de atitude).

Quanto aos objetos de atitude relacionados com o controle social, o balanço apresentado é diferente, com alguns resultados positivos em relação ao desempenho e um quanto à qualidade.

Ainda que tais achados possam parecer apenas "subjetivos", vale lembrar que a coerência na relação dos achados descritos e analisados aponta na direção do que afirma HELLER $(2000$, p. 13) ao asseverar que todo juizo de valor é também parte da totalidade de uma teoria e de uma concepção de mundo, e como tal não pode ser considerado subjetivo. 


\subsection{Definindo inovação}

No desenvolvimento das entrevistas e grupos focais foi diretamente solicitado que os participantes definissem o significado, para eles, da palavra "inovação". Com base nas muitas definiçōes surgidas selecionamos as consideradas mais significativas pela sua especificidade, sendo desprezadas as definiçōes com caracteristicas e significados muito semelhantes ou repetidas. A busca foi sempre pelo significado singular apresentado pelas definições. A partir da identificação prévia das unidades de textos que definissem a palavra "inovação" partimos para uma identificação do tema eixo da afirmação, seguindo a definição utilizada por BARDIN (1977, p. 105) de que "o tema é a unidade de significação que se liberta naturalmente de um texto analisado segundo critérios relativos à teoria que serve de guia à leitura".

Os resultados obtidos são apresentados nos Quadros 11, 11a, 11b, 11c e $11 \mathrm{~d}$ em que destaco os seguintes temas-eixos das definições: Inovação como tática do cotidiano; Inovação como concepção e aceitação do diferente; Inovação como ameaça; Inovação como criação transformadora; Inovação como ruptura; Inovação como criação do novo; Inovação como aperfeiçoamento da situação existente. 
Quadro 11 - Tema-eixo: Definido Inovação

\begin{tabular}{|c|c|c|}
\hline Tema-ixo & Definição & Autor \\
\hline \multirow[t]{4}{*}{$\begin{array}{l}\text { Inovação como } \\
\text { tática do cotidiano }\end{array}$} & $\begin{array}{l}\text { São coisas novas que eu posso } \\
\text { aproveitar, recriar, utilizar no } \\
\text { cotidiano para alcançar um } \\
\text { objetivo. Inovar, criar coisas } \\
\text { novas...(...). Do pouco que a gente } \\
\text { tem, temos que realizar alguma } \\
\text { coisa. E isso acontece muito no } \\
\text { cotidiano da gente. }\end{array}$ & $\begin{array}{l}\text { Membro da } \\
\text { Coordenação do } \\
\text { DSBRV }\end{array}$ \\
\hline & $\begin{array}{l}\text { Seria assim, trazer resistência ao } \\
\text { que é antigo....seria isso na saúde, } \\
\text { em relação à saúde. }\end{array}$ & \multirow[t]{2}{*}{$\begin{array}{l}\text { Trabalhadores da } \\
\text { Saúde }\end{array}$} \\
\hline & $\begin{array}{l}\text { Eu acho que é não deixar o } \\
\text { trabalho virar assim uma rotina. } \\
\text { (...). Renovar também. Criar, criar, } \\
\text { renovar e criar sempre. (...) vai } \\
\text { dando um jeitinho. }\end{array}$ & \\
\hline & $\begin{array}{l}\text { Eu acho que (a inovação) é você } \\
\text { pensar diferente. Ter um } \\
\text { pensamento, pensar como } \\
\text { exercício diferente do que você...do } \\
\text { que lhe chega, do que vocé escuta, } \\
\text { do que vocé próprio está } \\
\text { acostumado. De vocé poder criar } \\
\text { condições em você mesmo e no } \\
\text { espaço em que vocé trabalha pra } \\
\text { que o pensamento diferente } \\
\text { chegue. Eu acho que o resto vem } \\
\text { depois disso. }\end{array}$ & $\begin{array}{l}\text { Gerente de Unidade } \\
\text { de Saúde }\end{array}$ \\
\hline
\end{tabular}

Ainda que os trabalhadores da saúde se referissem freqüentemente às dificuldades de desenvolver 0 trabalho cotidiano, principalmente em relação à inexisténcia de planejamento local e precárias condições de trabalho, exemplificou-se muitas situações que reforçam o uso tático de desvios que facilitassem o trabalho cotidiano. É significativo também que somente na definição dos envolvidos com o trabalho técnico apareça a noção de tática como utilizada por DE CERTEAU (1998) e já definida anteriormente. 
Quadro 11a - Tema-eixo: Definido Inovação

\begin{tabular}{|c|c|c|}
\hline Tema-eixo & Definição & Autor \\
\hline \multirow[t]{6}{*}{$\begin{array}{l}\text { Inovação como } \\
\text { transformação e } \\
\text { ruptura }\end{array}$} & $\begin{array}{l}\text { Pra mim você inovar é você criar } \\
\text { algo de inusitado, algo } \\
\text { que...transformar. O inovar é } \\
\text { transformar alguma coisa que tá ali, } \\
\text { vocé transformar em algo diferente, } \\
\text { né. Pode dar certo ou não, mas } \\
\text { você está transformando. }\end{array}$ & $\begin{array}{l}\text { Gerente de Unidade de } \\
\text { Saúde }\end{array}$ \\
\hline & $\begin{array}{l}\text { Pra mim inovar é transformar, } \\
\text { mudar... pra melhor, pra melhor. } \\
\text { Ainda vai isso. Porque pode ser pra } \\
\text { pior, né? }\end{array}$ & $\begin{array}{l}\text { Trabalhadores da } \\
\text { Saúde }\end{array}$ \\
\hline & $\begin{array}{l}\text { Mudança. Eu acho que criar o novo, } \\
\text { inovar é vocé mudar o novo... } \\
\text { Ampliar o novo, mudar a cara do } \\
\text { novo. O processo é diferente de } \\
\text { vocé criar o novo. }\end{array}$ & $\begin{array}{l}\text { Conselheiros Locais de } \\
\text { Saúde (representantes } \\
\text { da comunidade) }\end{array}$ \\
\hline & $\begin{array}{l}\text { Inovação pra mim é criatividade, } \\
\text { criação. Acho que perspectiva de } \\
\text { uma coisa nova. Acho que tirar o } \\
\text { velho e botar o novo! (...) } \\
\text { Rompimento assim... romper... } \\
\end{array}$ & $\begin{array}{l}\text { Conselheiros Locais de } \\
\text { Saúde (representantes } \\
\text { dos trabalhadores da } \\
\text { saúde) }\end{array}$ \\
\hline & $\begin{array}{l}\text { A inovação é alguma coisa ou } \\
\text { algum elemento, algum movimento } \\
\text { que é novo, que apontasse no } \\
\text { sentido de melhorar aquela prática. } \\
\text { Inova-se para melhorar, inova-se } \\
\text { para resolver algum problema, } \\
\text { inova-se para possibilitar uma outra } \\
\text { realidade. }\end{array}$ & Membro do CMS \\
\hline & $\begin{array}{l}\text { (...). Tem que causar uma mudança. } \\
\text { O que tá bom não pode ficar ruim. } \\
\text { Gostar de tentar... tentativas. } \\
\text { Tentando consertar aquilo que deu } \\
\text { errado. }\end{array}$ & Usuários \\
\hline
\end{tabular}

As definições do Quadro 11a trazem elementos que se referem aos conceitos de inovação discutidos anteriormente. Primeiro, ultrapassa a idéia da inovação como a mera criação do novo, ao se referir também que há possibilidade de se criar a inovação a partir de algo já existente e que produza benefícios. No entanto, a possibilidade de a inovação produzir erros é admitida, bem como é 
reforçado o seu caráter transformador, levado ao extremo ao se definir a inovação como algo criado a partir do novo mas em substituição a ele mesmo.

Reforça-se nas definições acima, a compreensão da inovação como um espaço de ação tática e de intercâmbio de problemas de maior dimensão em problemas possiveis de serem enfrentados com os recursos existentes.

O diferencial nas definiçōes enunciadas é o caráter da inovação como movimento e não uma permanéncia a partir da mudança das estruturas, e a consciência de que deve existir certa desordem para a produção do novo.

Já os Quadros $11 \mathrm{~b}$ e $11 \mathrm{c}$ revelam uma dupla compreensão de inovação, compreensões que se complementam. Vejamos:

Quadro 11b - Tema-eixo: Definido Inovação

\begin{tabular}{|c|c|c|}
\hline Tema-eixo & Definição & Autor \\
\hline \multirow[t]{4}{*}{$\begin{array}{l}\text { Inovação como } \\
\text { criação do novo }\end{array}$} & $\begin{array}{l}\text { Bom, na verdade inovar, né, no sentido da } \\
\text { palavia é vocé criar uma coisa nova, é vocé } \\
\text { fazer com que alguma coisa nova... } \\
\text { apareça. }\end{array}$ & $\begin{array}{l}\text { Gerente de } \\
\text { Unidade de } \\
\text { Saúde }\end{array}$ \\
\hline & $\begin{array}{l}\text { E mudar, é dar uma roupagem nova. Algo } \\
\text { novo, algo... Inovação, inovar... mudanças. } \\
\text { Inovar é mudar, é criar coisas... mais atuais. }\end{array}$ & $\begin{array}{l}\text { Trabalhadores da } \\
\text { Saúde }\end{array}$ \\
\hline & $\begin{array}{l}\text { Inovação pra mim é algo novo; mudar } \\
\text { práticas antigas, mudar concepções } \\
\text { antigas, mesmo que esse algo novo } \\
\text { signifique considerar algo velho também. }\end{array}$ & $\begin{array}{l}\text { Conselheiros } \\
\text { Locais de Saúde } \\
\text { (representantes } \\
\text { da comunidade) }\end{array}$ \\
\hline & $\begin{array}{l}\text { Pra mim é assim, é a superação de práticas } \\
\text { que nós não queremos. (...). Pra mim o } \\
\text { novo é uma coisa que tá superando uma } \\
\text { coisa que não tá servindo pra população, } \\
\text { que não tá atendendo as necessidades da } \\
\text { população. Eu vejo o novo nesse sentido de } \\
\text { superar coisas, na busca de novos } \\
\text { propósitos, novas ações que vai ao } \\
\text { encontro dos interesses dessa população. }\end{array}$ & $\begin{array}{l}\text { Conselheiros } \\
\text { Locais de Saúde } \\
\text { (representantes } \\
\text { dos trabalhadores } \\
\text { da saúde) }\end{array}$ \\
\hline
\end{tabular}

A primeira, inovação como criação do novo, se relaciona diretamente com o significado da criatividade tradicional utilizada por PEILE (1994, p. 159; p. 199), 
que envolve uma transformação explícita de um estado prévio em novas formas. Essas novas formas seriam os resultados de movimentos de síntese, criados no dia-a-dia. Sintetizar seria a capacidade de estabelecer diferenças entre duas ou mais coisas ou situações e a habilidade em conduzir a diferença percebida no nivel conceitual, emocional ou prático. Tal capacidade é reconhecida como não previsível e incontrolável.

Quadro 11c - Tema-eixo: Definido Inovação

\begin{tabular}{|l|l|l|}
\hline \multicolumn{1}{|c|}{ Tema-eixo } & \multicolumn{1}{|c|}{ Definição } & \multicolumn{1}{|c|}{ Autor } \\
\hline $\begin{array}{l}\text { Inovação como } \\
\text { aperfeiçoamento } \\
\text { da situação } \\
\text { existente }\end{array}$ & $\begin{array}{l}\text { Inovação pra mim é pegar uma } \\
\text { situação atual e tentar modificá-la. } \\
\text { Inovar pra mim significa fazer } \\
\text { diferente do que está. É ter } \\
\text { criatividade, não é? }\end{array}$ & Membro do CMS \\
\cline { 2 - 3 } & $\begin{array}{l}\text { Algo novo é inovar práticas, inovar } \\
\text { concepções, inovar modelo. (...) } \\
\text { Nem sempre é no sentido de, de } \\
\text { negar, mas de, não é bem somar, } \\
\text { mas aperfeiçoar. Aperfeiçoar no } \\
\text { caminho evolutivo, progressivo. }\end{array}$ & $\begin{array}{l}\text { Conselheiros Locais } \\
\text { de Saúde } \\
\text { (representantes da } \\
\text { comunidade) }\end{array}$ \\
\hline & $\begin{array}{l}\text { Eu tava pensando que talvez } \\
\text { inovação não fosse uma coisa nova, } \\
\text { mas assim, a partir do velho a gente } \\
\text { criar algo novo. (...) Acho que dentro } \\
\text { do velho mesmo a gente inovar... }\end{array}$ & $\begin{array}{l}\text { Trabalhadores da } \\
\text { Saúde }\end{array}$ \\
\hline $\begin{array}{l}\text { Inovação pra mim é começar do } \\
\text { pequeno, voltar tudo de novo, } \\
\text { renovar o espírito, renovar as } \\
\text { formas, os trabalhos. Renovar pra } \\
\text { mim é a mesma coisa de, de } \\
\text { reformar. Reformar é construir algo. }\end{array}$ & Usuários \\
\hline
\end{tabular}

A segunda, inovação como aperfeiçoamento da situação existente, complementa a anterior ao ter o mesmo significado, dado que o novo que é criado não surge do nada, mas é resultado das sínteses sucessivas que se fazem sobre uma situação - que estabelece restrições e/ou facilidades - No entanto, esta é uma situação nova em seu contexto, por exigir um reconhecimento e aceitação por parte dos envolvidos na sua criação e utilização. 
Por fim, ilustramos com o exemplo abaixo a dificuldade dos atores em definir o significado de inovação. Frente à pergunta: 0 que significa a palavra "inovação" para você?, a maioria dos atores (das diferentes categorias de entrevistados/participantes dos grupos focais) solicitava que ela fosse repetida, ou afirmava que não tinha entendido a pergunta. Ainda que não possa afirmar as razões para tal hesitação ou dúvida, é interessante a reação de um deles retratada abaixo:

Quadro 11d - Tema-eixo: Definido Inovação

\begin{tabular}{|l|l|l|}
\hline \multicolumn{1}{|c|}{ Tema-eixo } & \multicolumn{1}{|c|}{ Definição } & \multicolumn{1}{c|}{ Autor } \\
\hline $\begin{array}{l}\text { Inovação como } \\
\text { ameaça }\end{array}$ & $\begin{array}{l}\text { Que é uma coisa inovadora? } \\
\text { (pausa longa). O..., eu não sei lhe } \\
\text { definir o que é uma... (pausa). Sei } \\
\text { não. Não (tom ligeiramente } \\
\text { irritado). (insisto na definição) Não, } \\
\text { com certeza eu faço, mas talvez eu } \\
\text { não saiba é me expressar. (pausa } \\
\text { longa) Me causa (a inovação) um } \\
\text { pouco de insegurança, de medo. }\end{array}$ & $\begin{array}{l}\text { Membro da } \\
\text { Coordenação do } \\
\text { DSRV }\end{array}$ \\
\hline
\end{tabular}

Poderia, o medo causado pela inovação, ser explicado como parte do medo que nos causa o próprio processo criativo, sem o qual a inovação não se dá? Isso porque todo processo criativo exige um movimento de ver através de si mesmo para fora, dado que a inovação, para nós, não é uma ação externa e intencional, mas dependente da nossa capacidade de processamento de informações; da exploração das motivações e capacidades individuais e abertura para critica interna e externa (URIBE RIVERA 1995, p. 103). 


\subsubsection{Quais categorias?}

Uma das novas contribuições para a categorização de inovaçōes na gestão pública é trazida por PINHO e SANTANA (1998) quando discutem a inovação como uma estratégia necessária no processo de gestão pública, principalmente no âmbito municipal, que deve enfrentar os graves problemas sociais existentes. Os autores apontam novas categorias inspiradas na análise do material empírico produzido no Programa Gestão Pública e Cidadania, patrocinado pela Fundação Getúlio Vargas e pela Fundação Ford. As inovações identificadas estariam agregadas em cinco categorias a saber: 1. Gestão democrática, definida como participativa, comunitária e sem paternalismo; 2 . Descentralização e desburocratização dos serviços públicos, intrinsecamente ligadas à primeira; 3 . Incorporação dos excluídos e minorias; 4. Valores para trás ou iniciativas de resgate dos valores tradicionais, desprezados ao longo do processo político e histórico da nossa sociedade; e, 5 . Valores para frente, significando a adoção de valores até então inexistentes na gestão subnacional e nacional.

Tais categorias, segundo os autores citados, têm um valor intrínseco por se originarem das experiências concretas analisadas. E, ainda que nos levem a pensar a inovação como diretamente relacionada à superestrutura política/organizacional, mantém uma perspectiva dialética, permitindo: 1. a introdução da perspectiva de outros atores sociais no processo de criação, disseminação e reconhecimento da inovação; 2 . o reconhecimento de processos inovadores que podem ser criados de "dentro para fora" e não somente como resultados das iniciativas institucionais; 3 . a identificação da inovação não apenas como produto.

Inspirada nas idéias dos autores acima referidos e imbuídos em contribuir com a definição de novas categorias para a investigação de inovações nos perguntamos: as definições analisadas podem inspirar a construção de categorias de inovação para a gestão em saúde? 
Posso responder a essa indagação sugerindo, a partir da identificação do tema-eixo inovação como tática, uma nova categoria. Isto me permite estudar as inovaçōes como resistências/mudanças produzidas nas práticas cotidianas, entendidas como modos, formas, processos e instrumentos adotados nas práticas de atores/gestores visando criar atitudes e modos de pensar que contribuam para o enfrentamento de situações consideradas desfavoráveis.

A categoria - inovação como tática - resgata um potencial quase sempre não referido nas investigações tradicionais sobre inovações na gestão pública no Brasil. Essa categoria pode ser desdobrada em duas outras subcategorias, visando expandir seu potencial analítico:

- A inovação como movimento;

- A inovação como ocupação de espaços programáticos institucionalizados.

A inovação como movimento consente analisar os aspectos contraditórios, fortemente presentes no âmbito da saúde em que, por exemplo, o incipiente controle social cria, no cotidiano, processos, modos e instrumentos de ação que ainda são desconhecidos e pouco analisados e se confrontam com resistências institucionais/organizacionais para o seu exercício prático. Amplia ainda a análise da inovação como uma ação de comunicação e não apenas como um resultado técnico.

Compreender a inovação como ocupação de espaços programáticos/institucionais nos autoriza, por sua vez, a penetrar na realidade do setor saúde cujas ações "bem definidas" do ponto de vista institucional estão circunscritas ainda hoje a uma lógica programática, cuja concepção e operação tem um forte conteúdo de imposição de cima para baixo. Esta subcategoria permite também entender e confirmar um papel protagonístico dos trabalhadores da saúde na coordenação, prestação e manutenção de ações e serviços. 


\subsection{Identificando inovações}

$\mathrm{Na}$ identificação de inovaçōes existiram exemplos bastante diferentes. As quatro inovações selecionadas o foram por terem sido reconhecidas/referidas como de maior relevåncia pelos entrevistados e pelos grupos focais, bem como pela consistência dos argumentos apresentados nas discussões dos grupos. Ao mesmo tempo, no início do trabalho de campo, as atividades exploratórias apontaram para as quatro inovações posteriormente confirmadas pelos atores locais. Todas as inovações foram citadas espontaneamente pelos entrevistados e membros dos grupos focais.

Alguns aspectos no processo da identificação das inovações merecem destaque.

Primeiro, o fato de que aluns dos membros da coordenaçāo do distrito sanitário e de grupos focais de usuários não foram capazes de identificar nenhum tipo de inovação na gestão local. Isso significa que as inovações analisadas ou não foram percebidas (caso dos usuários, em que apenas um grupo focal referese aos conselhos locais de saúde) ou foram negadas (caso dos coordenadores) por estarem relacionadas a fatos e circunstâncias contrárias aos interesses institucionais, como fica claro nas análises realizadas sobre o governo e a politica local e sobre o processo de gestão no distrito sanitário.

Segundo, muitas das inovaçōes identificadas seriam do tipo tático, isto é, produzidas nas dobras de flexibilidade possiveis em situações desfavoráveis para quem tem pouco poder. Seriam modos de agir no cotidiano, movimentos flutuantes que burlam as normas estabelecidas, visando prestar serviços e ações identificados como necessários e/ou mais coerentes com as necessidades locais. 
Terceiro, ainda que duas das inovaçōes existam no bojo de propostas institucionais como o Programa dos Agentes Comunitários de Saúde e Projeto UNI/BA, o caráter das inovações está fortemente relacionado com a utilização de espaços criados no movimento pragmático de tais intervenções e não na existência mesma de tais programas/projetos.

Quarto, o fato de que as inovaçōes identificadas se realizam no território do DSBRV, mas fora do espaço físico das unidades de saúde.

A Figura 4 a seguir apresenta as inovaçōes selecionadas segundo a relevância atribuídas a elas pelos atores que as identificam. São: $O$ movimento dos Conselhos Locais de Saúde (CLS); O espaço de atuação do Programa dos Agentes Comunitários de Saúde (PACS); A atuação em parceria do Projeto UNI/BA; $O$ trabalho contra a violéncia (assumida como um problema de saúde pública). 
Figura 4 - Identificação de inovações na gestão em saúde no DSBRV segundo a autoria, Salvador, 1999

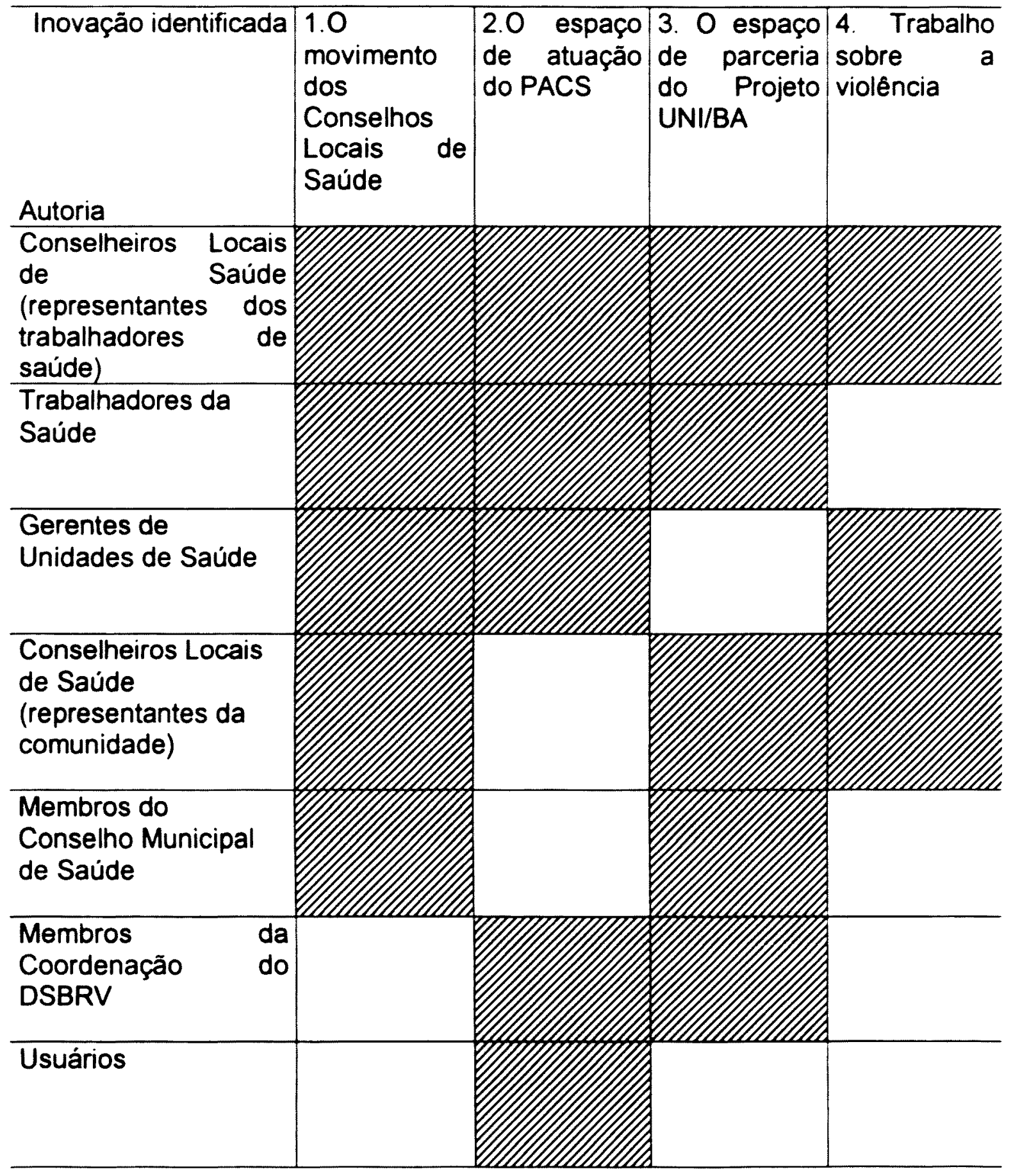




\subsubsection{Inovação: o movimento dos Conselhos Locais de Saúde}

Quando realizado o trabalho de campo no DSBRV, este contava com sete Conselhos Locais de Saúde em funcionamento (de um total de nove unidades básicas de saúde funcionando).

Iniciamos a análise sobre o movimento dos Conselhos Locais de Saúde com dois destaques. $O$ primeiro foi seu reconhecimento por quase todos os atores participantes da investigação, exceção para os membros da coordenação do DSBRV e usuários, e o segundo o fato de não ser a inovação a existência/constituição dos conselhos (que são uma iniciativa institucional/legal, implantados no municipio de Salvador a partir de 1993), mas a atuação destes na gestão da saúde no território estudado.

O não reconhecimento pelos usuários reforça a análise feita por conselheiros de saúde quanto à dificuldade de obtenção e divulgação de efeitos práticos na ação deles, bem como da "apatia política da população em geral, habituada ao assistencialismo predominante nas relações de poder na cidade".

Para a descrição e análise dos achados foram destacados aspectos relacionados com as caracteristicas locais dos CLS; concepções expressadas quanto ao papel e perfil dos conselheiros; inter-relações; táticas utilizadas na sua atuação; as repercussōes das ações desenvolvidas e a análise avaliativa dessa mesma atuação.

Considerados como "discrepantes", como "o novo" no distrito, mesmo que a coordenação do DSBRV não mantenha uma relação de coparticipação e co-gerência com eles, os conselhos locais de saúde possuem como caracteristicas: 
- A reestruturação por uma iniciativa e pressão da própria comunidade organizada (associações de moradores);

- O caráter de exercicio político "à esquerda" dos conselheiros representantes da comunidade;

- Uma atuação que interfere nas práticas e relações estabelecidas entre os serviços de saúde/comunidade local e universidade;

- Uma expressão de cidadania, via o movimento dos CLS, pelo direito à saúde e de participação na gestão da saúde;

- Ser espaço de negociação e atenuação de conflitos entre usuários dos serviços e trabalhadores da saúde.

\subsubsection{Papel dos Conselhos Locais de Saúde}

Existe um reconhecimento explícito de que a concepção, em geral, sobre o papel dos Conselhos de Saúde ainda é muito confusa, ainda que em menor proporção no DSBRV.

Nos grupos focais realizados com conselheiros locais fica claro que a existência dos CLS é também uma conquista do próprio movimento popular nos bairros e um espaço estratégico, na atual conjuntura, da luta mais ampla pelos direitos sociais. Para demonstrar essas concepções destaquei alguns enunciados que foram categorizados por seu tema-eixo: 
Quadro 12 - Papel dos CLS no DSBRV, 1999

\begin{tabular}{|c|c|c|}
\hline Tema-eixo & Como é descrito & Autor \\
\hline $\begin{array}{l}\text { CLS como } \\
\text { espaço amplo } \\
\text { de atuação por } \\
\text { direitos sociais }\end{array}$ & $\begin{array}{l}\text { Mas lá no Conselho Local de Saúde, a } \\
\text { gente costuma fazer de tudo... lá no } \\
\text { Conselho Local de Saúde, lá onde eu } \\
\text { moro, nós começamos a considerar um } \\
\text { monte de coisa questão de saúde: } \\
\text { transporte que não chega no horário } \\
\text { certo é um problema de saúde, porque } \\
\text { deixa a pessoa estressado (risos); deixa } \\
\text { a pessoa estressado. A violência, a a } \\
\text { gente considerou uma questão de saúde } \\
\text { porque está ligado diretamente à morte. } \\
\text { Tudo bem, tudo bem. É... a cultura seria } \\
\text { uma coisa ligada à questão de saúde } \\
\text { porque vocé alivia suas tensōes com o } \\
\text { fazer cultural, né e as próprias questōes } \\
\text { ligadas mesmo à saúde, porque tém } \\
\text { coisas que são diretamente ligadas à } \\
\text { saúde, é... como tuberculose (...). }\end{array}$ & $\begin{array}{l}\text { Conselheiros } \\
\text { Locais de } \\
\text { Saúde } \\
\text { (representantes } \\
\text { da comunidade) }\end{array}$ \\
\hline $\begin{array}{l}\text { CLS como ente } \\
\text { dialético entre } \\
\text { o institucional/ } \\
\text { comunitário }\end{array}$ & $\begin{array}{l}\text { Os Conselhos surgiram então, assim } \\
\text { como algo novo, né, algo novo; voltado } \\
\text { especificamente pra questão saúde, } \\
\text { mas com o caráter, no caso de nosso } \\
\text { distrito, com o caráter que a gente tá } \\
\text { dando lá e com o caráter que o SuS, é, } \\
\text { procura dar nos documentos que a } \\
\text { gente tem lido e tudo mais, de saúde... } \\
\text { da própria Constituinte... de não ser uma } \\
\text { questão somente da doença em si, mas } \\
\text { há múltiplos fatores sociais, } \\
\text { económicos, etc., que condiciona, } \\
\text { determina a questão da doença, na } \\
\text { própria Constituição tem isso. Isso deu } \\
\text { um papel novo ao Conselho, deu a sua } \\
\text { atitude como algo novo. Como algo } \\
\text { novo? Algo novo no sentido em que, ele } \\
\text { é ao mesmo tempo uma instituição, ele } \\
\text { é institucional, tá ligado à estrutura do } \\
\text { SUS, ele tem essa respeitabilidade de, } \\
\text { de, de ser reconhecido formalmente } \\
\text { pela lei e ao mesmo tempo tem algo que } \\
\text { é do movimento comunitário... que é a } \\
\text { independência, a autonomia. }\end{array}$ & \\
\hline
\end{tabular}


Destaca-se como aspecto contraditório o fato de que o respaldo por leis para a existência do CLS é reconhecido como favorável, dado que o contexto político local é desfavorável às manifestaçōes e participação social na gestāo da saúde, ao mesmo tempo que este mesmo fator é considerado impeditivo para uma atuação "mais radical" dos conselheiros representantes da comunidade. Estes reconhecem que um dos riscos na atuação dos CLS é ser confundido com a associação de bairro ou ser visto como uma mera extensão delas. Isso, segundo os conselheiros, limita a representatividade e agravaria o "fosso" existente entre os membros dos CLS e dificultaria a agregação e atuação mais efetiva dos representantes dos trabalhadores da saúde.

Esta preocupação parece ser o cerne da questão sobre o papel dos CLS. A possibilidade de maior reação dos CLS e, portanto, maior capacidade de ação efetiva na luta pela saúde está condicionada pela construçāo e ampliação dos espaços de articulação no cotidiano, articulação essa que deve ter como parceiros fundamentais a própria populaçāo local, os trabalhadores da saúde e outras organizações atuantes em cada área de abrangência dos conselhos. A imagem do CLS como sendo apenas os conselheiros representantes da comunidade, muitas vezes expressada pelos conselheiros representantes dos trabalhadores, tem dificultado a capacidade de articulação politica entre os próprios conselheiros. Outro aspecto que contribui na mesma direção é que, freqüentemente, a participação dos trabalhadores da saúde nos conselhos é imposta pelos gestores, além de que a maior representação entre estes conselheiros é dos trabalhadores do nivel médio.

Este fato tem dificultado também a consolidação de uma rede de solidariedade em torno da luta pela saúde, dado que esta se toma possivel à medida em que todos os atores locais passem a conhecer/reconhecer os espaços e interesses comuns. Nessa direção identificamos nas observações as tentativas de agregar novas lideranças à luta dos CLS, bem como a 
construção de alianças com lideranças vinculadas a outras correntes politicas, desde que defendessem a luta ampliada por saúde como direito social e qualidade de vida

\subsubsection{Perfil dos Conselheiros Locais de Saúde}

Durante as discussōes de grupo surgiam espontaneamente declarações sobre o perfil dos conselheiros de saúde. Alguns dos enunciados com esse conteúdo foram destacados e são apresentados identificando-se sua autoria e os qualificadores do perfil descrito. O destaque dos qualificadores, extraidos da própria unidade de análise, permite identificar alguns atributos dos que exercem o papel de conselheiros locais de saúde no DSBRV.

No Quadro 12 a seguir sobressaem atributos positivos do perfil dos atuais conselheiros. $O$ destaque fica para a coincidência de o único aspecto negativo atribuido estar relacionado com a inexperiência política de alguns conselheiros.

Os qualificadores positivos na descrição do perfil dos conselheiros parecem estar de acordo com o que caracteriza o diferencial da atuação dos Conselhos Locais de Saúde no DSBRV: estes se percebem com mais consciência social e política e com os interesses cada vez mais voltados para as necessidades coletivas. A concepção ampliada de saúde expressada é um destaque na "nova consciência" dos conselheiros de saúde, principalmente os representantes da comunidade. 
Quadro 13 - Perfil dos Conselheiros Locais de Saúde no DSBRV, Salvador, 1999

\begin{tabular}{|c|c|c|}
\hline Autor & Como é descrito & Qualificadores identificados \\
\hline \multirow{2}{*}{$\begin{array}{l}\text { Conselheiros Locais } \\
\text { de Saúde } \\
\text { (representantes dos } \\
\text { trabalhadores) }\end{array}$} & $\begin{array}{l}\text { Mas eu vejo que no distrito, nas reuniões com outras pessoas de outras comunidades, elas } \\
\text { têm uma postura mais critica e estão mais presentes, colocam questōes mais sobre o bairro, } \\
\text { sobre a questão da saúde. Eu vejo isso... }\end{array}$ & Uma postura mais crítica \\
\hline & $\begin{array}{l}\text { Eu entrei como suplente e o pessoal que tava entrando, o pessoal não tinha muita experiência } \\
(\ldots) \text {. }\end{array}$ & $\begin{array}{l}\text { O pessoal não tinha muita } \\
\text { experiência }\end{array}$ \\
\hline \multirow{4}{*}{$\begin{array}{l}\text { Conselheiros Locais } \\
\text { de Saúde } \\
\text { (representantes da } \\
\text { comunidade) }\end{array}$} & $\begin{array}{l}\text { Uma coisa também inovadora, que a gente não fica só, como conselheiro, não fica só presa, } \\
\text { né? a gente vê a problemática como um todo, né? a saúde como um todo. Como é } \\
\text { saneamento básico, né?, a violência como, né?, atinge as pessoas, os tipos de violência. }\end{array}$ & $\begin{array}{l}\text { A gente vê a problemática (da } \\
\text { saúde) como um todo }\end{array}$ \\
\hline & $\begin{array}{l}\text { E uma outra coisa também é a independência, né? A gente é mais independente pra cobrar, } \\
\text { certo? Nós temos mais poder (enfatiza a palavra) pra cobrar. Nos sentimos assim, mais fortes } \\
\text { (fala com certo orgulho), né? com a criação do Conselho. }\end{array}$ & $\begin{array}{l}\text { A gente é mais independente } \\
\text { Nós temos mais poder }\end{array}$ \\
\hline & $\begin{array}{l}\text { E hoje, né, de uns seis anos pra cá, nós temos uma outra posição dentro da comunidade. Nós } \\
\text { estamos preocupados mesmo com o social, nós estamos preocupados, né, acreditando nesse } \\
\text { novo momento e tamos preocupados em se organizar a nivel de conselho de saúde, a nivel de } \\
\text { conselho de segurança, a nível de associação, para buscar condiçōes melhores mesmo, pra } \\
\text { comunidade. Nós acreditamos, o grupo nosso acredita, né, que nós só vamos conseguir } \\
\text { avançar se tivermos organizados, né, nesse sentido de buscar melhoria, buscar a cidadania. }\end{array}$ & $\begin{array}{l}\text { Nós estamos preocupados } \\
\text { mesmo com o social }\end{array}$ \\
\hline & $\begin{array}{l}\text { Os conselheiros são novos... pra buscar a questão mesmo da consciência, da cidadania... E } \\
\text { isso de imediato é difícil, pôr isso nós temos dificuldade de reunir um maior número de } \\
\text { pessoas, né, pra buscar essa coisa. }\end{array}$ & $\begin{array}{l}\text { Os conselheiros são novos... } \\
\text { pra buscar a questão mesmo } \\
\text { da consciència, da cidadania }\end{array}$ \\
\hline
\end{tabular}




\subsubsection{Ações e táticas do cotidiano}

Destacamos a seguir algumas das fragilidades e pontos fortes apontados pelos atores do DSBRV quanto à atuação dos conselhos locais de saúde

- Falta de clareza quanto ao papel de conselheiro

- Atuação restrita na sua área de abrangência e sem articulaçāo entre os CLS e inexistência de uma agenda política comum

- Atuação mais voltada (e limitada) ao setor saúde

- Pouco envolvimento nos CLS de lideranças com compromisso politico com a população

- A atuação corporativa dos conselheiros representantes dos trabalhadores da saúde

- A relação conflitante entre representantes da comunidade e dos trabalhadores da saúde

- A concepção dominante que faz com que os CLS se resumam, na prática, aos conselheiros representantes da comunidade

- Desconhecimento, pela população local em geral, da existência e da ação dos CLS

- Pequena participação de outros membros da comunidade local e de trabalhadores nas reuniōes

- Fragilidade na condução das reuniōes dos CLS (inexistência de pauta definida e acompanhamento das deliberaçōes)

- Dificuldade de acesso à midia
Pontos Fortes

- Os CLS exercendo uma "política popular" e não partidária, isto é, voltada aos interesses da população local

- A independência de ação dos conselheiros representantes da comunidade

- O reconhecimento legal dos CLS, que favorece a ação independente e fortalece o papel de conselheiro

- O reconhecimento e atuação de alguns CLS do conceito ampliado de saúde, englobando intervenções sobre aspectos sociais e econômicos da cidade

- A dupla face dos CLS enquanto uma instância institucional e que permite uma ação autônoma por parte dos representantes dos movimentos comunitários

- O espaço dos CLS permitindo a convivência e aceitação das diferenças

- Regularidade na realização das reuniōes dos CLS 
Nos Quadros analíticos 14, 15 e 16 apresentados a seguir foram sistematizadas as açōes e táticas referidas na atuação dos conselheiros locais de saúde. Elas estão sistematizadas em unidades de texto que descrevem tais ações identificando-se a seguir o tema da intervenção e as táticas/recursos utilizados na ação. As unidades de texto que se referiam a um mesmo tema, ainda que enunciadas por atores diferentes, foram excluidas. 
Quadro 14 - Atuação dos Conselhos Locais de Saúde no DSBRV por Membros do Conselho Municipal de Saúde, 1999

\begin{tabular}{|c|c|c|}
\hline Como é descrita & $\begin{array}{c}\text { Tema do } \\
\text { investimento } \\
\text { politico }\end{array}$ & $\begin{array}{c}\text { Táticas/recursos } \\
\text { utilizados }\end{array}$ \\
\hline $\begin{array}{l}\text { Por exemplo, a questão do } \\
\text { laboratório do } 15^{\circ} \text { centro de } \\
\text { saúde. Havia uma decisão da } \\
\text { secretaria de deixar o } 15^{\circ} \text { só } \\
\text { como posto de coleta e o } \\
\text { laboratório ser centralizado no } \\
5^{\circ} \text { Centro de Saúde. Bom, hoje } \\
\text { as pessoas da secretaria } \\
\text { dizem que foi...houve um mal- } \\
\text { entendido por parte do } \\
\text { Conselho do } 15^{\circ} \text {. Porque eles } \\
\text { interpretaram como } \\
\text { fechamento do laboratório, } \\
\text { fechamento significava } \\
\text { prejuizo para a comunidade. } \\
\text { Então atuaram em cima disso } \\
\text { e fizeram com que a prefeitura } \\
\text { mudasse de posição e } \\
\text { desistisse de fechar o } \\
\text { laboratório. }\end{array}$ & $\begin{array}{l}\text { Manter o } \\
\text { serviço de } \\
\text { laboratório no } \\
15^{\circ} \text { Centro de } \\
\text { Saúde em } \\
\text { funcionamento }\end{array}$ & $\begin{array}{l}\text { - Manifestação com } \\
\text { participação de } \\
\text { usuários e lideranças } \\
\text { - Articulação com outras } \\
\text { entidades } \\
\text { - Velocidade da } \\
\text { resposta (em } 24 \\
\text { horas) } \\
\text { Divulgação por rádio } \\
\text { comunitária } \\
\text { Abaixo-assinado de } \\
\text { usuários } \\
\text { Conhecimento prévio } \\
\text { do CLS sobre dados } \\
\text { de produção do } \\
\text { laboratório } \\
\text { Encaminhamento de } \\
\text { denúncia ao CMS }\end{array}$ \\
\hline $\begin{array}{l}\text { Por exemplo, a reforma do } 9^{\circ} \\
\text { centro foi uma vitória pra } \\
\text { todos nós, pra comunidade e } \\
\text { pros trabalhadores. Porque } \\
\text { diferentemente do da Santa } \\
\text { Cruz, o Conselho Local do } 9^{\circ} \\
\text { Centro teve acesso até da } \\
\text { planta. (...). Então o Conselho } \\
\text { Local interviu junto com o } \\
\text { CMS e levou e convenceu a } \\
\text { secretária que não tinha como } \\
\text { fazer aquele tipo de reforma, } \\
\text { entendeu? E aí foi aprovado a } \\
\text { reforma completa, da parte } \\
\text { elétrica e hidráulica. }\end{array}$ & $\begin{array}{l}\text { Reforma da } \\
\text { estrutura física } \\
\text { da unidade de } \\
\text { saúde }\end{array}$ & $\begin{array}{l}\text { - Permanência da } \\
\text { reforma como ponto } \\
\text { de pauta nas reuniões } \\
\text { do CLS } \\
\text { - Elaboração de } \\
\text { documento-proposta } \\
\text { Divulgação com } \\
\text { usuários do serviço } \\
\text { Participação no plano } \\
\text { de desativação } \\
\text { temporária de serviços } \\
\text { da unidade } \\
\text { Acompanhamento das } \\
\text { obras } \\
\text { Reuniões com } \\
\text { presença da } \\
\text { coordenadora do } \\
\text { distrito e } \\
\text { representantes da } \\
\text { SMS }\end{array}$ \\
\hline
\end{tabular}


Quadro 15 - Atuação dos Conselhos Locais de Saúde no DSBRV por Conselheiros Locais de Saúde representantes da comunidade, 1999

\begin{tabular}{|c|c|c|}
\hline Como é descrita & \begin{tabular}{|c|} 
Tema do \\
investimento \\
politico
\end{tabular} & Táticas/recursos utilizados \\
\hline $\begin{array}{l}\text { Então, aconteceu o seguinte: nós tínhamos o conselho e nós } \\
\text { conseguimos assim, convidar algumas outras pessoas que não } \\
\text { faziam parte de estrutura de pensamento de esquerda. Mas } \\
\text { conseguimos trazer pessoas que são do PFL pra estrutura } \\
\text { porque até então, (...) não tinha essa disponibilidade de } \\
\text { participar, de se organizar dentro de um conselho local de saúde. }\end{array}$ & $\begin{array}{l}\text { Fortaleciment } \\
\text { o da } \\
\text { capacidade de } \\
\text { ação dos CLS }\end{array}$ & $\begin{array}{l}\text { - Articulação com representantes de } \\
\text { forças politicas diferentes }\end{array}$ \\
\hline $\begin{array}{l}\text { Eu, assim, como conselheira, eu, na minha atuação, eu fico } \\
\text { assim, às vezes dentro assim de um questionamento e tentando } \\
\text { buscar soluções para determinadas situações. (...). Por exemplo, } \\
\text { se eu tô numa fila de ônibus, se tem alguém se queixando ou } \\
\text { tem alguém conversando sobre algo, né?, em relação à saúde, à } \\
\text { política, condiçōes de vida no geral. Daí eu fico assim ouvindo, } \\
\text { observando pra sentir como é que essas pessoas tão } \\
\text { percebendo, por exemplo, se ela vai numa clínica que tem } \\
\text { convênio com o SUS, como é o atendimento lá, o que é que } \\
\text { vocẻs acham, como é que tá isso e as pessoas vão dando } \\
\text { opinião (...) e lá no final, no dia da reunião, que é mensal, lá no } \\
\text { conselho local de saúde, a gente levar essas discussões, pra } \\
\text { junto a gente buscar soluções, né?, pra melhoria do } \\
\text { atendimento. }\end{array}$ & $\begin{array}{l}\text { Melhoria do } \\
\text { atendimento }\end{array}$ & $\begin{array}{l}\text { Escuta no cotidiano da opinião da } \\
\text { comunidade local } \\
\text { - Discussão de propostas de } \\
\text { intervenção em reuniōes } \\
\text { - Ações em parceria com a } \\
\text { universidade/profissionais dos } \\
\text { serviços } \\
\text { - Estabelecer relação cordial com } \\
\text { gestor }\end{array}$ \\
\hline
\end{tabular}


Quadro 15 - Atuação dos Conselhos Locais de Saúde no DSBRV por Conselheiros Locais de Saúde representantes da comunidade, 1999 - Continuação

\begin{tabular}{|c|c|c|}
\hline Como é descrita & $\begin{array}{c}\text { Tema do } \\
\text { investimento } \\
\text { político }\end{array}$ & Táticas/recursos utilizados \\
\hline $\begin{array}{l}\text { Eu acho que a campanha "declare amor ao seu bairro", ela } \\
\text { deve ser repensada, deve ser centrada, deve ser repensada, } \\
\text { porque (...), ai vai ser uma arma de conduzir de uma certa } \\
\text { igualdade da comunidade. Saber que a comunidade carente, } \\
\text { ela se mobiliza, certo? E ela tenta, tenta barrar a violência, é, } \\
\text { de ambos os lados. A gente tentando barrar a violência da } \\
\text { gente, certo? Que é a violência que é gerada em nosso bairro, } \\
\text { certo? Só que atrelar a essa violência a violência que nós } \\
\text { sofremos de cima para baixo. }\end{array}$ & $\begin{array}{l}\text { Trabalho com a } \\
\text { violência }\end{array}$ & $\begin{array}{l}\text { - Mobilização de moradores para } \\
\text { valorização do bairro } \\
\text { - Realização de eventos } \\
\text { culturais } \\
\text { - Manifestaçōes públicas: } \\
\text { caminhadas pela paz } \\
\text { - Divulgação na midia } \\
\text { - Organização de atividades } \\
\text { permanentes com jovens } \\
\text { moradores dos bairros } \\
\text { Identificação de recursos locais } \\
\text { para uso dos moradores } \\
\end{array}$ \\
\hline $\begin{array}{l}\text { Tem áreas, ou locais, ou acesso a informações, acesso a } \\
\text { determinadas coisas que o fato de ter pessoas, como tinha } \\
\text { (cita o nome da ex-gerente do DSBRV), que era gerente do } \\
\text { distrito, permitia... Eu acredito que o PACS, o agente } \\
\text { comunitário não saiu (...), ou seja, com pessoas mais } \\
\text { descomprometidas porque a gente tava lá. (...) a gente } \\
\text { conseguiu definir um critério, impor esse critério lá, verificar, } \\
\text { controlar isso. }\end{array}$ & $\begin{array}{l}\text { Intervenção na } \\
\text { seleção dos } \\
\text { agentes do PACS }\end{array}$ & $\begin{array}{l}\text { Apresentação de proposta de } \\
\text { critérios à coordenação do } \\
\text { DSBRV e CMS } \\
\text { - Fiscalização da seleção dos } \\
\text { agentes no DSBRV }\end{array}$ \\
\hline
\end{tabular}


Quadro 16 - Atuação dos Conselhos Locais de Saúde no DSBRV por Conselheiros Locais de Saúde representantes dos trabalhadores da saúde, 1999

\begin{tabular}{|c|c|c|}
\hline Como é descrita & $\begin{array}{c}\text { Tema do investimento } \\
\text { político }\end{array}$ & Táticas/recursos utilizados \\
\hline $\begin{array}{l}\text { Nós fizemos... o conselho local... nós fizemos } \\
\text { um projeto pra trabalhar é... no médico da } \\
\text { familia. Nós sentamos lá três meses... pessoal } \\
\text { da UNI, (...), nós sentamos, depois nós } \\
\text { convidamos Dr X e Dra } Y \text {, nós sentamos ali, } \\
\text { conversamos dois meses, nós elaboramos o } \\
\text { projeto, entendeu? }\end{array}$ & $\begin{array}{l}\text { Intervenção na organização } \\
\text { dos serviços }\end{array}$ & $\begin{array}{l}\text { - Parceira com trabalhadores da saúde } \\
\text { - Elaboração de projetos/propostas de } \\
\text { intervenção }\end{array}$ \\
\hline $\begin{array}{l}\text { Até a própria diretora da unidade. Nós } \\
\text { questionamos a saida dela de lá da unidade. Por } \\
\text { que ela saiu? Qual seria o perfil que a secretaria } \\
\text { municipal, o distrito sanitário tava querendo, né? }\end{array}$ & $\begin{array}{l}\text { Intervenção na mudança de } \\
\text { gerentes de unidades de } \\
\text { saúde }\end{array}$ & $\begin{array}{l}\text { - Manifestações públicas } \\
\text { - } \text { Abaixo-assinado } \\
\text { - Audiências junto ao CMS } \\
\text { - Denuntóncias à midia }\end{array}$ \\
\hline $\begin{array}{l}\text { Por exemplo, agora na Conferência (refere-se à } \\
\text { IV Conferência Municipal de Saúde), antes o } \\
\text { distrito não se reunia pra discutir. Isto é uma } \\
\text { coisa também muito positiva, uma coisa } \\
\text { diferente. }\end{array}$ & $\begin{array}{l}\text { Intervenção na IV } \\
\text { Conferência Municipal de } \\
\text { Saúde }\end{array}$ & $\begin{array}{l}\text { - Articulação política entre os CLS, membros do } \\
\text { CMS e trabalhadores da saúde, estudantes e } \\
\text { professores da universidade e usuários para } \\
\text { discussão de propostas à IV CMS } \\
\text { - Organização de reunióes preparatórias } \\
\text { - Elaboração de documento-proposta } \\
\text { - Distribuição de panfleto-denúncia sobre a } \\
\text { - Rituação da saúde em Salvador } \\
\text { - Realização de passeata (junto com outras } \\
\text { - Panganizações) durante a IV Conferência } \\
\text { - Participação como delegados à IV CMS }\end{array}$ \\
\hline
\end{tabular}


Com o painel de atuação dos CLS contidos nas descrições posso afirmar que este espaço permite uma maior penetração dos grupos organizados e facilita a negociação política com autoridades

Também facilita a articulação de redes não permanentes em torno de interesses comuns. Os temas do investimento político demonstram que a capacidade de ação é abrangente, mas caracterizada por formas e modos tradicionais de intervenção política. O mais grave no entanto é que a atuação dos CLS pode ser considerada como fragmentada e pragmática, não existindo uma agenda definida e articulada para ação.

Por outro lado, a necessidade de agregação de esforços é uma estratégia já reconhecida pelos conselheiros, que iniciaram uma articulação para a formação de um conselho distrital com agregação de outros parceiros não exclusivamente atuantes na área da saúde, mas que não foi levada adiante. Existe uma concentração de açōes em torno de temas com características "administrativas", não existindo um acompanhamento efetivo das politicas e mesmo das denúncias apresentadas.

É pertinente referir que a atuação dos CLS é pouco percebida pelos moradores locais e usuários dos serviços públicos de saúde, que não faz menção à atuação dos CLS nos grupos focais. Apenas um grupo se refere à articulação desenvolvida pelos conselheiros com novas lideranças dos bairros para participar de reuniōes e eventos, investindo na ampliação da capacidade de ação dos CLS. 


\subsubsection{Repercussōes}

A seleção e análise de algumas repercussōes do movimento dos Conselhos Locais de Saúde foram feitas através de enunciados que permitissem uma auto-reflexão dos atores sobre esse processo. As categorias utilizadas, surgidas dos próprios enunciados, são: repercussōes "funcionais"; repercussōes sobre a ação dos gestores institucionais; sobre os serviços de saúde; nos conselheiros de saúde, e na população.

\section{Repercussões "funcionais"}

Muitas das repercussões ainda se situam em categorias funcionais (como a realização de reuniōes periódicas ou número de conselhos em funcionamento) mas apontam também outras perspectivas que não são diretamente expressas nos enunciados. Dentre tais perspectivas destacamse a mudança de atitude dos conselheiros locais de saúde e a possibilidade de acesso a informação, ilustrados a seguir:

\section{Quadro 17 - Repercussões funcionais}

\begin{tabular}{|l|l|}
\hline \multicolumn{1}{|c|}{ Como é descrita } & \multicolumn{1}{|c|}{ Autor } \\
\hline $\begin{array}{l}\text { Atribuo a melhor organização dos conselhos, melhor } \\
\text { funcionamento dos conselhos. Sem dúvida eles } \\
\text { passaram a funcionar com mais regularidade. Isso } \\
\text { está relacionado a um processo de discussão, de } \\
\text { capacitação e de apoio do Projeto UNI aqui no } \\
\text { Distrito Barra/Rio Vermelho. }\end{array}$ & \\
\hline $\begin{array}{l}\text { Eu não sei se é diferente mas o Distrito Barra/Rio } \\
\text { Vermelho, ele tem mais dados, os resultados desses } \\
\text { encontros que houve nas unidades de ensino, } \\
\text { saúde. Acho que isso faz uma diferença sim. }\end{array}$ & $\begin{array}{l}\text { Conselheiros Locais de } \\
\text { Saúde (representantes dos } \\
\text { trabalhadores da saúde) }\end{array}$ \\
\hline $\begin{array}{l}\text { Mas observe que nos outros distritos não há nada. } \\
\text { O nosso Distrito Barra/Rio Vermelho é o que tem } \\
\text { maior número de conselhos organizados. A maioria } \\
\text { é média de um, dois. No máximo! }\end{array}$ & $\begin{array}{l}\text { Conselheiros Locais de } \\
\text { Saúde (representantes da } \\
\text { comunidade) }\end{array}$ \\
\hline
\end{tabular}


Repercussões sobre a ação dos gestores institucionais

Uma outra categorização para as repercussões são as relacionadas com o "incômodo" que o movimento causa às autoridades, o que é significativo, dado que percebe-se um silêncio sobre a existência dos CLS por parte de alguns membros da coordenação do DSBRV, reforçado pelas observações de campo em que foram constatadas várias tentativas de "controle" sobre a ação dos CLS por parte da coordenação do distrito.

Quadro 18 - Repercussões sobre a ação dos gestores institucionais

\begin{tabular}{|l|l|}
\hline \multicolumn{1}{|c|}{ Como é descrita } & \multicolumn{1}{|c|}{ Autor } \\
\hline $\begin{array}{l}\text { Pra mim, assim, um dos pontos positivos, assim, } \\
\text { bem significativo, por exemplo, a ampliedade (sic) } \\
\text { que essas discussões, que a nossa atuação vem } \\
\text { tomando no Distrito Barra/Rio Vermelho, não é? } \\
\text { Porque veja, tá existindo uma preocupação maior } \\
\text { das autoridades, mesmo que eles não queiram } \\
\text { deixar que a gente perceba que eles se preocupa } \\
\text { com a nossa atuação. (...) eles tão preocupados } \\
\text { pra que isso não crie maiores problemas, né?, até } \\
\text { pra ferir a imagem deles. }\end{array}$ & $\begin{array}{l}\text { (representantes da } \\
\text { comunidade) }\end{array}$ \\
\hline $\begin{array}{l}\text { Melhorou mesmo, melhorou bastante. Teve uma } \\
\text { melhorazinha. Melhorou, porque antes nós nem } \\
\text { sabia que ia consertar posto, que ia fazer, que ele } \\
\text { fazia o planejamento dele lá e trazia, e agora ele } \\
\text { só faz se a gente quiser, como agora que nós } \\
\text { estamos lá dizendo: ou ele dá a relação do que vai } \\
\text { gastar, do que não vai, nós estamos cobrando. Eu } \\
\text { achei isso uma grande mudança. A participação } \\
\text { popular. A participação. A participação popular. É, } \\
\text { eu acho que aos troncos e barrancos eles estão } \\
\text { ouvindo, né?, eles estão ouvindo, tão... obrigados } \\
\text { pela pressão. }\end{array}$ & \\
\hline
\end{tabular}




\section{Repercussões nos serviços}

O aspecto de maior repercussão foi a manutenção do laboratório do $15^{\circ}$ Centro de Saúde, referido por conselheiros de saúde, trabalhadores da saúde e até por usuários. No entanto, as repercussōes nos serviços se caracterizam como pontuais e não se referem a nenhuma intervenção na mudança das práticas sanitárias ou na implantação de politicas de interesse da população local.

Quadro 19 - Repercussōes nos serviços

\begin{tabular}{|l|l|}
\hline \multicolumn{1}{|c|}{ Como é descrita } & \multicolumn{1}{|c|}{ Autor } \\
\hline $\begin{array}{l}\text { E eu acho também que tem coisas assim que, falar } \\
\text { assim, a nivel de Santa Cruz tá assim, é pequena } \\
\text { as coisas, mas pelo menos os médicos estão indo } \\
\text { mais, estão mais preocupados, por exemplo, é um } \\
\text { conselheiro que, era do conselho, chegou, então } \\
\text { todo mundo já tá preocupado com isso, porque } \\
\text { sabe que você tem consciência do que não é certo, } \\
\text { né? }\end{array}$ & $\begin{array}{l}\text { Conse saúde } \\
\text { (representantes da } \\
\text { comunidade) }\end{array}$ \\
\hline $\begin{array}{l}\text { E a luta pra surgir o agente comunitário de saúde } \\
\text { foi deles, do conselho. Do conselho e das } \\
\text { associações de bairros...Conselho Municipal. }\end{array}$ & $\begin{array}{l}\text { Trabalhadores da } \\
\text { saúde }\end{array}$ \\
\hline $\begin{array}{l}\text { Como aconteceu que eles queriam tirar o } \\
\text { laboratório do 15 Centro e houve uma } \\
\text { manifestação por parte da comunidade, alguns } \\
\text { dirigentes, o pessoal do conselho de saúde fez a } \\
\text { mobilização e disse: "não tira". }\end{array}$ & \\
\hline
\end{tabular}

\section{Repercussões na população}

Uma das maiores fragilidades identificadas anteriormente na ação dos CLS é o seu conhecimento/reconhecimento pela população local. Isso é reflexo da própria postura da população - analisada como acomodada e pouco politizada por conselheiros locais de saúde —, mas é também um reflexo da própria condução política das associaçōes de moradores 
tradicionalmente considerada assistencialista e patemalista, reforçando a acomodação. Como exemplo de uma situação diferenciada temos:

Quadro 20 - Repercussões na população

\begin{tabular}{|l|l|}
\hline \multicolumn{1}{|c|}{ Como é descrita } & \multicolumn{1}{|c|}{ Autor } \\
\hline $\begin{array}{l}\text { O trabalho, ele é, é, existe uma notabilidade por parte } \\
\text { da comunidade, tanto é que nas eleiçōes do Conselho } \\
\text { você vê, a população vai votar no Conselho Local de } \\
\text { Saúde, é... a notabilidade existe, né? pode não existir } \\
\text { até tanto admirando, mas é notável. O trabalho é } \\
\text { notável e, na última eleição mesmo, nós tivemos } \\
\text { com... acabaram as cédulas, foram quatrocentas e } \\
\text { poucas cédulas confeccionadas e acabaram (...). }\end{array}$ & $\begin{array}{l}\text { Locais de Saúde } \\
\text { (representantes da } \\
\text { comunidade) }\end{array}$ \\
\hline $\begin{array}{l}\text { Tudo isso a comunidade, eles estão tendo consciência } \\
\text { de que eles podem fazer alguma coisa, se eles } \\
\text { quiserem, através do Conselho Local. Agora é preciso } \\
\text { também que a gente, como conselho, a gente não } \\
\text { fique muito fechado. Que a gente se abra mesmo pra } \\
\text { comunidade. }\end{array}$ & $\begin{array}{l}\text { Conselheiros } \\
\text { Locais de Saúde } \\
\text { (representantes } \\
\text { dos trabalhadores } \\
\text { da saúde) }\end{array}$ \\
\hline
\end{tabular}

\section{Repercussões nos conselheiros}

As repercussōes identificadas pelos próprios membros dos Conselhos Locais ultrapassam uma mera valorização do papel deles como conselheiros. Até porque durante as discussões nos grupos focais surgem referências quanto às dificuldades de aceitação na própria comunidade do papel dos conselheiros, que, como afirmam, são considerados como pessoas que gostam de criar polêmica. As enunciações indicam um claro sentimento de solidariedade e deixam perceber que são também reconhecidas pelos conselheiros as dificuldades na obtenção de resultados na atuação dos Conselhos de Saúde. Existe, em muitas expressões, um forte sentido do investimento pessoal/afetivo no trabalho e há também uma perspectiva positiva de que o trabalho realizado cria repercussões. 
Quadro 21 - Repercussões nos conselheiros locais de saúde

\begin{tabular}{|c|c|}
\hline Como é descrita & Autor \\
\hline $\begin{array}{l}\text { É positivo mesmo esse meu trabalho, não tô } \\
\text { dizendo que eu tô trabalhando de graça, que } \\
\text { eu já ganhei milhões em participar duma } \\
\text { ajuda na comunidade, de ajudar o povo, } \\
\text { ajudar a minha familia que mora lá, que } \\
\text { precisa ir pra médico vai por lá mesmo, e } \\
\text { outros que não podem ir pra lugar nenhum. } \\
\text { E além do aprendizado que eu tenho tido, } \\
\text { né? (...). Você entra na luta pra ficar pra seu } \\
\text { filho, seu neto. Entra na luta dos } \\
\text { conselheiros, não vai ficar atrás de governo } \\
\text { não. Entra na luta pra lutar pela comunidade } \\
\text { que consegue. }\end{array}$ & \multirow[t]{2}{*}{$\begin{array}{l}\text { Conselheiros Locais de } \\
\text { Saúde (representantes da } \\
\text { comunidade) }\end{array}$} \\
\hline $\begin{array}{l}\text { Porque nesse mesmo ambiente, nesse } \\
\text { processo de seminários, de discussões, de } \\
\text { passeatas, de trabalho comum, a gente tem } \\
\text { certeza que as pessoas vão avançando; e } \\
\text { vão se comprometendo; e vão } \\
\text { conscientizando mais e, claro que nem } \\
\text { todos, mas num grupo vai se construindo } \\
\text { numa força. E essa força, com certeza se } \\
\text { reflete em outros distritos, se reflete em } \\
\text { outras... }\end{array}$ & \\
\hline $\begin{array}{l}\text { É... eu acho que minha atitude, né, minha } \\
\text { atitude mudou e mudou muito, né? } \\
\text { Principalmente a relação com o pessoal, né? } \\
\text { Com a odontologia, a nossa área aqui, ela é } \\
\text { muito restrita dentro ali do consultório, né? O } \\
\text { paciente chegou, bateu na porta ali, você se } \\
\text { isola do mundo. Na convivência (através do } \\
\text { Conselho) aí a gente tá aprendendo muito, } \\
\text { não é? Respeitar o outro,... é vê não só uma } \\
\text { coisa...você até conversar com o paciente. } \\
\text { Eu tenho aprendido muito isso né? }\end{array}$ & $\begin{array}{l}\text { Conselheiros de saúde } \\
\text { (representantes dos } \\
\text { trabalhadores da saúde) }\end{array}$ \\
\hline
\end{tabular}




\subsubsection{Avaliação dos Conselhos Locais de Saúde}

Na pré-análise dos achados foram identificadas as unidades de texto com conteúdo avaliador direcionado aos Conselhos Locais de Saúde. As unidades foram selecionadas de modo a que não se repetissem e foram analisadas com base na técnica de análise de avaliação adaptada aos objetivos especificos da pesquisa. As enunciações foram pronunciadas espontaneamente pelos participantes das entrevistas e grupos focais. Os Quadros 22, 22a, 22b, 22c, 22d apresentam os resultados da avaliação por autor.

Um balanço final, a partir da freqüência dos aspectos positivos e negativos enunciados, cruzando todos os objetos de atitude e autores revela uma avaliação negativa quanto ao desempenho (cinco negativos e quatro positivos) e positiva quanto às qualidades (cinco positivas e duas negativas).

Os destaques ficam para a divergência quanto à avaliação do mesmo objeto de atitude - atuação dos CLS - cujo balanço quanto ao desempenho é negativo para os trabalhadores da saúde e para os próprios conselheiros de saúde representantes da comunidade. 
Quadro 22 - Análise avaliativa dos CLS por Conselheiros Locais de Saúde representantes da comunidade, DSBRV, 1999

\begin{tabular}{|c|c|c|c|c|}
\hline Como é descrita & Objeto de atitude & Conector verbal & Termo avaliativo & $\begin{array}{l}\text { Resultado da } \\
\text { avaliação }\end{array}$ \\
\hline $\begin{array}{l}\text { Mas eu acho que a gente tem que ir } \\
\text { muito além das, dessas discussões, a } \\
\text { gente ainda tá muito em cima disso aí. A } \\
\text { gente percebe, tem consciência, mas na } \\
\text { hora de resolver ai é que tá, né?, dar um } \\
\text { passo maior. }\end{array}$ & \multirow[t]{3}{*}{ Atuação do CLS } & $\begin{array}{l}\text { Tem } \\
\text { Percebe } \\
\text { Tem }\end{array}$ & Que ir muito além & $\begin{array}{l}\text { Desempenho } \\
\text { negativo } \\
\text { Qualidade positiva }\end{array}$ \\
\hline $\begin{array}{l}\text { São poucos os Postos de Saúde que o } \\
\text { Conselho tem influência. }\end{array}$ & & São & Poucos & $\begin{array}{l}\text { Desempenho } \\
\text { negativo }\end{array}$ \\
\hline $\begin{array}{l}\text { Ainda não deu pra desenvolver melhor a } \\
\text { atividade, mas é totalmente qualificativo } \\
\text { os trabalhos dos Conselhos depois da } \\
\text { formação. E uma coisa totalmente } \\
\text { diferente do que as associações tinham } \\
\text { vivido porque é trabalho com pessoas já } \\
\text { com um conceito diferente, com ampla } \\
\text { expansão do trabalho: universidade, } \\
\text { comunidade, saúde. }\end{array}$ & & $\begin{array}{l}\text { Deu } \\
\dot{E}\end{array}$ & $\begin{array}{l}\text { Desenvolver } \\
\text { melhor } \\
\text { Totalmente } \\
\text { diferente } \\
\begin{array}{l}\text { Expansão do } \\
\text { trabalho }\end{array}\end{array}$ & $\begin{array}{l}\text { Desempenho } \\
\text { positivo }\end{array}$ \\
\hline
\end{tabular}

Balanço: As enunciações avaliativas indicam o reconhecimento de qualidade positiva na atuação do CLS e uma avaliação de desempenho que tende ao negativo. 
Quadro 22a - Análise avaliativa dos CLS por Gerentes de Unidades de Saúde, DSBRV, 1999

\begin{tabular}{|c|c|c|c|c|}
\hline Como é descrita & Objeto de atitude & Conector verbal & Termo avaliativo & $\begin{array}{l}\text { Resultado da } \\
\text { avaliação }\end{array}$ \\
\hline $\begin{array}{l}\text { E acho que a comunidade, ela tem } \\
\text { condição e ela vai, de fato, ficar mais } \\
\text { presente, como uma entidade de } \\
\text { decisão, de decisão do processo.(...) } \\
\text { mas eu sinto a possibilidade, eu sinto a } \\
\text { inquietação é ainda da comunidade. E } \\
\text { acho que ela tem condições e tem } \\
\text { trabalhado muito pra isso. Muito. }\end{array}$ & $\begin{array}{l}\text { Atitude dos } \\
\text { representantes da } \\
\text { comunidade }\end{array}$ & $\begin{array}{l}\text { Tem } \\
\text { Ficar }\end{array}$ & $\begin{array}{l}\text { Condição } \\
\text { Inquietação } \\
\text { Trabalhado } \\
\text { Mais presente }\end{array}$ & $\begin{array}{l}\text { Qualidade positiva } \\
\text { Desempenho } \\
\text { positivo }\end{array}$ \\
\hline $\begin{array}{l}\text { Outro tipo de reunião que existe numa } \\
\text { periodicidade mensal é a reunião do } \\
\text { conselho local de saúde, né? Então } \\
\text { essa é uma reunião que existe } \\
\text { inclusive uma rotina até bem mais } \\
\text { estabelecida do que as reuniões dos } \\
\text { técnicos. }\end{array}$ & $\begin{array}{l}\text { Funcionamento/ } \\
\text { organização }\end{array}$ & Existe & $\begin{array}{l}\text { Reunião com } \\
\text { rotina } \\
\text { estabelecida }\end{array}$ & $\begin{array}{l}\text { Desempenho } \\
\text { positivo }\end{array}$ \\
\hline
\end{tabular}

Balanço: As enunciaçōes avaliativas indicam o reconhecimento de qualidade positiva na atitude dos representantes da comunidade no CLS e uma avaliação de desempenho positiva tanto em relação à atitude quanto ao funcionamento. 
Quadro 22b - Análise avaliativa dos CLS por Conselheiros Locais de Saúde representantes dos trabalhadores da saúde, DSBRV, 1999

\begin{tabular}{|c|c|c|c|c|}
\hline Como é descrita & Objeto de atitude & Conector verbal & Termo avaliativo & $\begin{array}{l}\text { Resultado da } \\
\text { avaliação }\end{array}$ \\
\hline $\begin{array}{l}\text { Existem coisas por trás do Conselho } \\
\text { que são... que a gente não... (...). No } \\
\text { nosso assim... aparentemente a gente } \\
\text { percebe que o conselho, ele é um } \\
\text { pouco subdividido, que ele não é tão } \\
\text { coeso assim, as idéias não são as } \\
\text { mesmas pras mesmas pessoas. }\end{array}$ & $\begin{array}{l}\text { Relações internas } \\
\text { ao CLS }\end{array}$ & 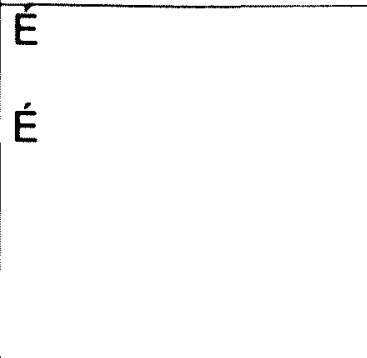 & $\begin{array}{l}\text { Um pouco } \\
\text { subdividido } \\
\text { Não coeso }\end{array}$ & $\begin{array}{l}\text { Qualidade } \\
\text { negativa }\end{array}$ \\
\hline $\begin{array}{l}\text { Mesmo no Conselho, as pessoas que } \\
\text { são representantes da comunidade, } \\
\text { essas pessoas não tem tido...se } \\
\text { colocado com enfrentamento, seja } \\
\text { contra a unidade ou questionando, } \\
\text { contra a associação mesmo, não tem. }\end{array}$ & $\begin{array}{l}\text { Atitude de } \\
\text { representantes da } \\
\text { comunidade }\end{array}$ & Tem & $\begin{array}{l}\text { Sem } \\
\text { enfrentamento } \\
\text { Não questionando }\end{array}$ & $\begin{array}{l}\text { Desempenho } \\
\text { negativo }\end{array}$ \\
\hline
\end{tabular}

Balanço: As enunciações avaliativas indicam o reconhecimento de qualidade negativa nas relações internas ao CLS e um desempenho também negativo quanto aos representantes da comunidade no CLS. 
Quadro 22c - Análise avaliativa dos CLS por membros do Conselho Municipal de Saúde, DSBRV, 1999

\begin{tabular}{|c|c|c|c|c|}
\hline Como é descrita & $\begin{array}{l}\text { Objeto de } \\
\text { atitude }\end{array}$ & $\begin{array}{l}\text { Conector } \\
\text { verbal }\end{array}$ & $\begin{array}{c}\text { Termo } \\
\text { avaliativo }\end{array}$ & $\begin{array}{l}\text { Resultado da } \\
\text { avaliação }\end{array}$ \\
\hline $\begin{array}{l}\text { Então às vezes os Conselhos se perdem no esforço de tentar resolver } \\
\text { problemas pequenos, que são problemas administrativos. A gente vê } \\
\text { Conselhos é, preocupados em ajudar na reforma da unidade, até de } \\
\text { conselheiros substituindo, fazendo o trabalho de pintar a parede. } \\
\text { Acho que perde um pouco o papel de conselho enquanto instância e } \\
\text { fórum de controle, de discussão da politica e da participação na } \\
\text { gestão. Há uma, há problemas de direção no Conselho. }\end{array}$ & $\begin{array}{l}\text { Atuação do } \\
\text { CLS }\end{array}$ & $\begin{array}{l}\text { Perdem } \\
\text { Tentar resolver } \\
\text { Há }\end{array}$ & $\begin{array}{l}\text { Problemas } \\
\text { pequenos } \\
\text { Problemas de } \\
\text { direção }\end{array}$ & $\begin{array}{l}\text { Desempenho } \\
\text { negativo }\end{array}$ \\
\hline $\begin{array}{l}\text { E no Barra/Rio Vermelho a gente tem um processo de atuação mais } \\
\text { autônoma, mais independente dos Conselhos. }\end{array}$ & & Tem & $\begin{array}{l}\text { Atuação } \\
\text { autônoma/ } \\
\text { independente }\end{array}$ & $\begin{array}{l}\text { Qualidade } \\
\text { positiva }\end{array}$ \\
\hline $\begin{array}{l}\text { (...) os Conselhos neste último ano, os conselhos aqui no Distrito } \\
\text { Barra/Rio Vermelho melhoraram. A gente percebe por exemplo, na } \\
\text { atuação do Conselho do } 9^{\circ} \text { Centro de Saúde, do } 15^{\circ} \text { Centro de } \\
\text { Saúde, eles conseguiram modificar, dar direção a algumas ações que } \\
\text { foram tentadas ser implantadas pela prefeitura e que seria, na análise } \\
\text { deles, na avaliação deles, prejuizo para a comunidade. }\end{array}$ & & $\begin{array}{l}\text { Percebe } \\
\text { Conseguiram } \\
\text { Dar }\end{array}$ & $\begin{array}{l}\text { Modificar } \\
\text { Direção a } \\
\text { algumas ações }\end{array}$ & $\begin{array}{l}\text { Desempenho } \\
\text { positivo }\end{array}$ \\
\hline
\end{tabular}

Balanço: As enunciações avaliativas indicam o reconhecimento de desempenho e qualidade positivos na atuação do CLS e também um desempenho negativo relacionado com um papel considerado não pertinente aos conselheiros. Quanto à composição dos CLS, identifica-se uma qualidade negativa pela predominância, na representação dos trabalhadores, dos de nível médio. 
Quadro 22d - Análise avaliativa dos CLS por Trabalhadores da Saúde, DSBRV, 1999

\begin{tabular}{|c|c|c|c|c|}
\hline Como é descrita & $\begin{array}{l}\text { Objeto de } \\
\text { atitude }\end{array}$ & $\begin{array}{c}\text { Conector } \\
\text { verbal }\end{array}$ & $\begin{array}{c}\text { Termo } \\
\text { avaliativo }\end{array}$ & $\begin{array}{l}\text { Resultado da } \\
\text { avaliação }\end{array}$ \\
\hline $\begin{array}{l}\text { Por conta disso eu acho que o Conselho realmente } \\
\text { não está cumprindo o seu papel. As discussões, as } \\
\text { cobranças a nivel da unidade em relação, porque a } \\
\text { comunidade cobra "por que o profissional não está } \\
\text { atendendo ou não atendeu tal dia", é muito esse } \\
\text { tipo de coisa, ou por que o serviço tal não está } \\
\text { funcionando. }\end{array}$ & $\begin{array}{l}\text { Atuação do } \\
\text { Conselho }\end{array}$ & Está & $\begin{array}{l}\text { Não cumpre } \\
\text { seu papel }\end{array}$ & $\begin{array}{l}\text { Desempenho } \\
\text { negativo }\end{array}$ \\
\hline $\begin{array}{l}\text { Eu acho que existe medo da comunidade (por parte } \\
\text { dos dirigentes da SMS), sabe. Da reação da } \\
\text { comunidade. O Conselho como tem representante } \\
\text { da comunidade, eu acho que ele ganha força. }\end{array}$ & $\begin{array}{l}\text { Composição do } \\
\text { Conselho }\end{array}$ & $\begin{array}{l}\text { Tem } \\
\text { Ganha }\end{array}$ & $\begin{array}{l}\text { Representante } \\
\text { da comunidade } \\
\text { Força }\end{array}$ & $\begin{array}{l}\text { Qualidade } \\
\text { positiva }\end{array}$ \\
\hline $\begin{array}{l}\text { O Conselho é que é importante para mostrar as } \\
\text { dificuldades da comunidade, as dificuldades do } \\
\text { posto, entendeu, dos profissionais. Também a } \\
\text { realidade. }\end{array}$ & $\begin{array}{l}\text { Função do } \\
\text { Conselho }\end{array}$ & $E$ & Importante & $\begin{array}{l}\text { Qualidade } \\
\text { positiva }\end{array}$ \\
\hline
\end{tabular}

Balanço: As enunciações avaliativas indicam o reconhecimento de desempenho negativo na atuação do CLS e qualidade positiva quanto à sua composição e ao seu papel. 


\subsubsection{Comentários finais}

A própria análise feita pelos conselheiros aponta ainda muitas limitações ao trabalho do Conselho. As mais destacadas são relacionadas com as dificuldades de mobilização da própria comunidade, freqüentemente explorada por políticos profissionais, principalmente nos períodos de eleição, causando o que eles chamam de "vício do assistencialismo".

Reconhecem também os limites na capacidade de articulação entre os Conselhos e lideranças comunitárias bem como a ação ainda restrita, pouco direcionada e de pouco impacto. Como perspectivas apontam para a constituição do Conselho Distrital como um espaço de articulação mais amplo, incluindo representantes da universidade e outras entidades e instituições. Reconhecem também a importância de ter uma maior presença nas reuniōes do Conselho Municipal de Saúde e mesmo representantes neste fórum.

No entanto, o fato de os CLS serem formas estruturais de participação não tem impedido o seu movimento no DSBRV como um espaço diferenciado, enquanto núcleo de criação de formas de autogestão da saúde.

A persistência da SMS em tentar negar e desconhecer este movimento tem impedido a própria modernização da gestão em saúde, reforçando o que reconhece KLIKSBERG ao afirmar que "no discurso, a participação triunfou na América Latina" (1999, p. 25), mas ainda está longe de ser assumida pelos órgãos governamentais como fator relevante para garantir formas de gestão eficazes. 
No caso, caracteriza-se como formas de resistência à participação na gestão via os CLS a visão da organização da saúde no DSBRV em que "a ordem, a hierarquia, o mando, os processos formalmente regulados e uma percepção verticalista e autoritária da organização são as chaves da eficiência" (KLIKSBERG 1999, p. 28). Isso reforça os achados anteriores sobre a condução da política local, em que a tendência a uma participação manipulada e a manutenção exclusiva do poder negam à cidade a sua possibilidade de agir enquanto espaço de reconfiguração de poderes e de realização (DOWBOR 1994, 1996).

Por fim, para fomentar a polêmica vale registrar que os Conselhos Locais de Saúde estão imbuídos do espirito de busca de maior competência da gestão moderna do que o próprio DSBRVISMS desde que têm, mesmo num contexto político desfavorável, ajudado a romper padrões tradicionais de gestão, e desenvolvendo e reconhecendo a capacidade de articular novas parcerias, com o exemplo de segmentos da universidade numa articulação cujo eixo tem sido cada vez mais o compromisso com a saúde enquanto um direito social.

Mesmo com todos os limites identificados, o movimento dos CLS foi considerado, na perspectiva dos atores locais e na minha, a partir das observações e reflexões inseridas no contexto, uma inovação com características transformadoras. Não é ele uma recusa à ordem da coerção? Não pode apontar para elementos de um modelo de gestão em saúde preocupado em gerir os princípios da universalidade; eqüidade; integralidade e democratização da saúde? Não são a participação e o controle social o caminho que pode nos levar a assegurar a saúde como direito de todos e dever do estado? 


\subsubsection{Inovação: o espaço de atuação do Programa dos Agentes Comunitários de Saúde/PACS}

\subsubsection{Premissas}

O PACS - Programa dos Agentes Comunitários de Saúde - foi desenhado pelo Ministério da Saúde com base em experiência desenvolvida anteriormente no estado do Ceará, nos anos 80/90. É parte da estratégia definida no Programa de Saúde da Família/PSF, para o fortalecimento da atenção básica no sistema municipal de saúde. A equipe do PACS, que é parte integrante da equipe do PSF, é composta uma enfermeira coordenadora e um grupo de agentes comunitários de saúde (ACS), moradores nas microáreas em que o programa atua. Tais áreas são selecionadas com base nos fatores de riscos sociais e epidemiológicos identificados. Implantado a partir de 1994, segundo dados recentes funciona em 4.052 municipios com um total de 111.659 agentes comunitários (BRASIL 2000). Em Salvador, o PACS é implantado a partir de dezembro de 1998.

\subsubsection{PACS: significado e uso estratégico local}

De que modo o espaço do PACS é considerado uma inovação na gestão do DSBRV? Esta foi a nossa primeira pergunta ao analisarmos uma intervenção programática como esta, implantada por decisão do nível central da Secretaria Municipal da Saúde.

Tentando responder a essa indagação é que apresentaremos os achados e as análises sobre o PACS enquanto inovação considerando o seu significado local, uso estratégico e repercussões. Por fim, o PACS é também 
submetido a uma análise de avaliação através das enunciações que denotam atitudes e julgamentos em relação ao modo como atua no DSBRV.

A seguir, O PACS é revelado conforme seu significado e usos estratégicos pelos atores locais, o que ultrapassa seu mero significado de programa estrutural cuja implantação foi decidida pelo gestor municipal. 
Quadro 23 - Espaço de atuação do PACS: significado e uso estratégico

\begin{tabular}{|c|c|c|c|}
\hline Como é descrito & Autor & Significado & Uso estratégico local \\
\hline $\begin{array}{l}\text { A gente tá achando até bem melhor agora (o trabalho do Conselho } \\
\text { Local), com esse aproveitamento dos trabalhos dos Agentes } \\
\text { Comunitários, são eles que vão de casa em casa, que tá vivendo } \\
\text { mais esse... é, como é que posso dizer... essa tormenta, que é a } \\
\text { convivência da população do bairro. Pra poder passar pra gente. }\end{array}$ & $\begin{array}{l}\text { Conselheiros Locais } \\
\text { de } \quad \text { Saúde } \\
\text { (representantes da } \\
\text { comunidade) }\end{array}$ & $\begin{array}{l}\text { Permite conhecer } \\
\text { como vive a } \\
\text { população }\end{array}$ & $\begin{array}{l}\text { Subsidia, com } \\
\text { informações, o } \\
\text { trabalho do conselho } \\
\text { local }\end{array}$ \\
\hline $\begin{array}{l}\text { Embora eu reconheça que o programa de agentes comunitários aqui } \\
\text { no Barra/Rio Vermelho, ele se organizou diferente de muitos outros } \\
\text { distritos. Houve um envolvimento, uma participação dos conselhos } \\
\text { mais ativa e muito peitada (sic) pelos elementos da comunidade. } \\
\text { Muito assim, espaço batalhado, conseguido, conquistado e eles } \\
\text { foram muito ativos nesse processo. Então se evitou as indicações } \\
\text { político-partidárias (...). }\end{array}$ & Membro do CMS & $\begin{array}{l}\text { Organização } \\
\text { diferenciada pelo } \\
\text { envolvimento dos } \\
\text { Conselhos Locais de } \\
\text { Saúde }\end{array}$ & $\begin{array}{l}\text { Evitou interferèncias } \\
\text { político-partidária na } \\
\text { seleção dos Agentes } \\
\text { Comunitários de } \\
\text { Saúde/ACS }\end{array}$ \\
\hline $\begin{array}{l}\text { Tá tendo a participação da comunidade, né, antes a gente não tinha } \\
\text { essa participação, é, com o PACS muito mais, porque hoje o PACS, } \\
\text { ele tá indo pra comunidade. }\end{array}$ & $\begin{array}{l}\text { Gerente de Unidade } \\
\text { de Saúde }\end{array}$ & $\begin{array}{l}\text { Ampliar a } \\
\text { participação da } \\
\text { população local }\end{array}$ & $\begin{array}{l}\text { Espaço de expressão } \\
\text { das necessidades da } \\
\text { população }\end{array}$ \\
\hline $\begin{array}{l}\text { A única inovação que vejo no momento é o PACS. Por quê? Parte do } \\
\text { levantamento de problemas especifico de cada área; os agentes têm } \\
\text { uma noção de vigilância à saúde e o ACS mostra que a pessoa está } \\
\text { viva, que tem que reivindicar. Ele tá acordando a população. }\end{array}$ & $\begin{array}{l}\text { Membros } \\
\text { Coordenação } \\
\text { DSBRV }\end{array}$ & $\begin{array}{l}\text { Inovando práticas de } \\
\text { saúde }\end{array}$ & $\begin{array}{l}\text { Apoio ao trabalho de } \\
\text { luta por saúde e } \\
\text { condições de vida da } \\
\text { população }\end{array}$ \\
\hline
\end{tabular}


Muito da inovação em que se constitui o PACS para os atores locais é dado pelo seu significado enquanto revelador das condições de vida e saúde da população local. Isso porque, através das demandas trazidas aos serviços de saúde pelos agentes comunitários de saúde, tanto os gestores locais quanto os trabalhadores de saúde (principalmente uma maioria de médicos, odontólogos, farmacêuticos, etc.) têm sido "obrigados" a se defrontar com situações e condições de saúde que até então buscavam ignorar, dada a predominância de práticas sanitárias curativas e restritas ao interior das unidades de saúde.

Por outro lado também é reconhecido pelos atores locais o papel relevante da diferença em que se constituiu a implantação do PACS no Distrito Sanitário Barra/Rio Vermelho, através da intervenção dos Conselhos Locais de Saúde. Tal origem tem possibilitado algum grau de articulação entre o trabalho dos ACS e dos conselheiros de saúde, ainda que exista um reconhecimento mútuo de que tal articulação, ainda que importante, é ainda insuficiente.

O significado de inovação que o PACS contém, no entanto, não encobre a sua utilização com outras finalidades e os problemas dai decorrentes. Selecionamos algumas unidades de análise que se destacaram por enunciar problemas significativos em relação à implantação e funcionamento do PACS no DSBRV. Elas revelam também que a identificação do PACS como inovação está distante de um olhar acrítico por parte dos atores locais. Para analisá-los utilizamos recursos da técnica de análise de enunciação em relação aos elementos atípicos que apresentam. 


\section{Enunciado 1: o PACS como barreira de proteção}

Então, nós somos o correio da saúde, mais assim, informadores da saúde. O povo tá gostando, tá sendo mais informado, mas... e a educação, e o saneamento básico, e a fome... e muitas... por detrás disso tem muita coisa que é saúde também e nós não temos como resolver, ficamos desejando resolver e com certeza eu não sinto apoio de nenhum desses setores pra resolver com a gente. Que é assim, botar a gente como uma muralha forte na frente, mas pra poder ter uma base... retorno. Não tem não, viu? É dificil! No fundo, no fundo é... não existe um trabalho que eles (os dirigentes, a SMS) tenham muita vontade, eu acho que não têm muita vontade não, na minha opinião.

\section{Autor: Agentes Comunitários de Saúde}

No enunciado 1 vemos claramente o uso de uma metáfora em que o trabalho dos Agentes Comunitários de Saúde/ACS é considerado como uma muralha forte na frente, com a conotação de proteger e defender a própria instituição responsável pela prestação de açōes e saúde no território do distrito, dos seus usuários. Ainda que reconheçam o aspecto positivo na sua função de "informar a população" os ACS também reconhecem que tal papel é insuficiente para enfrentar os problemas de saúde, ao mesmo tempo que constatam não existir apoio formal para a obtenção de resultados efetivos sobre os problemas identificados.

\section{Enunciado 2: Os ACS como uma peça da engrenagem institucional}

Começamos agora um pouquinho... temos assim uma visão que a coisa tá indo, mas depende muito... (Ironicamente) É como se a gente fosse a máquina querendo trabalhar, mas depende muito das pessoas que vai botar o óleo pra máquina trabalhar... (...). Dar manutenção à máquina... ( $E$ o que é mais importante pra essa máquina?). A mão de obra, as condições... A parceria... trabalhar em parceria.

\section{Autor: Agentes Comunitários de Saúde}

No enunciado 2, os ACS utilizam a metáfora deles mesmos como uma máquina que para funcionar precisa de insumos básicos e manutenção. De novo a conotação derivada da figura de retórica utilizada revela que o trabalho por eles realizados é insuficiente para dar conta dos problemas 
identificados e que não existe um interesse por quem deve promover os meios para que se desenvolva um trabalho eficaz, ou seja, os gestores institucionais e outros parceiros no local.

\section{Enunciado 3: Utilização político-partidária do PACS}

Mas nós tamo preocupados também é com nossos agentes de saúde, que eles têm que saber quem são eles, porque que eles estão ali, o que eles estão fazendo, porque eles não devem nada aos políticos, aos cara de pau (sic), né?, eles não devem nada. (...). Não tem nada a ver, as comunidades se mobilizaram e conquistaram esse direito. Isso aí foi uma conquista de vocês. Então eu acho que as outras comunidades também precisam brigar nesse sentido, porque senão Agente de Saúde vai virar cabo eleitoral (silêncio).

Autor: Conselheiros de Locais de Saúde (representantes da comunidade)

A preocupação fundamental que é claramente denotada do enunciado é quanto à possibilidade de utilização do trabalho dos ACS para finalidade político-partidária. Tal preocupação foi registrada tanto durante as observações de campo quanto em outros momentos, através das entrevistas e grupos focais. Pela sua freqüência nos achados esta pode ser considerada o aspecto mais relevante para conselheiros de saúde e trabalhadores. Tal ênfase se justifica por duas razões: primeiro por ter sido realizado o trabalho de campo num ano (1999) que antecedia a realização das eleições municipais em todo o pais e segundo pelo forte envolvimento dos Conselhos Locais na seleção dos ACS, fato este referido como de agregação de poder político pelos CLS e reconhecido como um dos resultados da sua ação.

\subsubsection{Repercussões}

As repercussões da atuação do PACS foram categorizadas através do tema-eixo do conteúdo das unidades de análise em: repercussão nos serviços de saúde; nos trabalhadores; e na população da área. 
Quadro 24 - Repercussões nos serviços de saúde

\begin{tabular}{|l|l|}
\hline \multicolumn{1}{|c|}{ Como é descrita } & \multicolumn{1}{|c|}{ Autor } \\
\hline $\begin{array}{l}\text { Pelo menos lá no meu serviço, com o PACS aumentou a } \\
\text { produtividade, aumentou a demanda, aumentou o } \\
\text { serviço, aumentou o compromisso, eu acho assim que... } \\
\text { pelo menos eu... eu estou muito mais satisfeita hoje do } \\
\text { que um certo tempo atrás. Que você vê assim que você } \\
\text { dá encaminhamento às coisas e tá tendo, de certa forma, } \\
\text { uma resolução do problema. }\end{array}$ & $\begin{array}{l}\text { Conselheiros } \\
\text { Locais } \\
\text { Saúde } \\
\text { (representantes } \\
\text { dos } \\
\text { trabalhadores } \\
\text { da saúde) }\end{array}$ \\
\hline $\begin{array}{l}\text { Ai eu pensei aqui agora uma definição bem assim... acho } \\
\text { que dá pra combinar com o que aconteceu: é como se } \\
\text { fosse um urso siberiano, a Unidade de Saúde ou a saúde } \\
\text { em geral de Salvador é um urso que tá dormindo há } \\
\text { muitos anos. A chegada dos agentes com um bocado de } \\
\text { vara (risos), futucando aquele urso, futucou e mexeu em } \\
\text { muita coisa. Ele acordou feroz porque ele não gostaria de } \\
\text { ser acordado e tá, ficou aquela coisa bastante } \\
\text { constrangedora. Ele não gostou de acordar, nós tamos } \\
\text { mostrando muitos pontos que ninguém sabia, não se } \\
\text { preocupava em cobrar ou não queria resolver e nós } \\
\text { estamos ali! }\end{array}$ & \\
\hline $\begin{array}{l}\text { Os agentes de saúde estão vindo na unidade, estão } \\
\text { vendo as coisas, tão criticando, tão se reunindo e com } \\
\text { isso tá fazendo pressão; tá fazendo pressão! Eu acho } \\
\text { que eles vão chegar a um nível que eles tão tendo a } \\
\text { oportunidade deles conversarem com a secretária; de } \\
\text { levar os problemas para o prefeito, e eu acredito, é a } \\
\text { única esperança que eu acho, é que eu acho, é que } \\
\text { através deles possa ser que a gente possa melhorar, } \\
\text { porque vai haver pressão. }\end{array}$ & \\
\hline $\begin{array}{l}\text { Então o PACS tá trazendo uma demanda nova, maior, e } \\
\text { que tá realmente precisando... (...). As unidades já } \\
\text { estavam desestruturadas para atender as pessoas que já } \\
\text { atendiam e ainda teria a demanda do PACS, certo? É } \\
\text { realmente uma coragem porque tá vindo, surgindo coisas } \\
\text { novas, e eles (ACS) estão mobilizando a comunidade. }\end{array}$ & $\begin{array}{l}\text { Trabalhadores } \\
\text { da Saúde }\end{array}$ \\
Saúde \\
\end{tabular}

As repercussões nos serviços de saúde guardam relação com a preocupação com o aumento de demanda aos serviços. No entanto fica claro que existe realmente um "constrangimento" por parte das unidades de saúde à presença e cobranças feitas pelos ACS para o atendimento da 
população encaminhada por eles aos serviços.

Os próprios ACS usam de uma metáfora para definir 0 constrangimento que causam nos serviços e nos trabalhadores da saúde ao ser utilizada a expressão "a Unidade de Saúde ou a saúde em geral de Salvador é um urso que tá dormindo há muitos anos", e revelavam a satisfação que estavam tendo em acordá-lo.

Ao mesmo tempo os ACS são depositários de algo como "uma última esperança" de promover mudanças nos serviços. Em primeiro lugar porque são reconhecidos como possíveis interlocutores com autoridades, dado que estes participaram de várias reuniões com dirigentes da SMS e com o prefeito e outros secretários municipais, revelando a importância do Programa para a SMS. Essa importância é reforçada pela observação durante o trabalho de campo de que a reunião com enfermeiras do PACS era a única realizada regularmente pela Coordenação do DSBRV. Em segundo lugar pela postura reconhecida como "mais crítica" dos ACS, num contexto político em que a postura dos trabalhadores da saúde, com raras exceções, tem sido de submissão e silêncio frente à condução reconhecida como autoritária na gestão da saúde, como nos depoimentos abaixo:

Então a coisa tá de um jeito que estou achando que a gente tá vivendo um momento de passividade. Eu tô nessa. (...). Tô assim, entregando os pontos. (Grupo focal com trabalhadores da saúde)

Tá errado! Porque tá num limite de decisão coletiva mesmo. A gente tá se submetendo cada vez mais e a gente não tá fazendo nada! Ninguém tá fazendo nada! Cada vez mais a gente tá assim, retraído, a gente tá se retraindo por desgaste mesmo. Já se reivindicou muito, já se batalhou muito, já se fez muito e que foi que a gente teve de retorno? Coisa nenhuma. (Grupo focal com trabalhadores da saúde) 


\section{Repercussões nos trabalhadores}

Do ponto de vista tático o PACS tem permitido movimentos de ruptura no que foi chamado de "marasmo dos serviços e dos profissionais". Tais mudanças, ainda que pequenas e mesmo imperceptiveis enquanto conjunto, demonstram o efeito do trabalho do PACS sobre os trabalhadores da saúde, principalmente por demandar uma atuação na área de moradia da população assistida e impor uma realidade que é muito mais fácil de ser mascarada quanto se desenvolve o próprio trabalho apenas intramuros.

Registramos também expressões de desagrado com o trabalho dos ACS e questionamentos quanto à sua competência. Um dos mais interessantes reflete a preocupação de que o trabalho da saúde se limite à atuação dos ACS e que haja alguma intenção encoberta da SMS em acabar com as unidades de saúde, dado o estado destas, que oferecem precárias condições de trabalho, e a crescente compra de serviços básicos do setor privado.

Quadro 24a - Repercussões nos trabalhadores da saúde

\begin{tabular}{|l|l|}
\hline \multicolumn{1}{|c|}{ Como é descrita } & \multicolumn{1}{|c|}{ Autor } \\
\hline $\begin{array}{l}\text { Quando você assiste, como os agentes estão assistindo, as } \\
\text { enfermeiras do PACS estão vendo como eles (a população } \\
\text { da área) vivem, elas começam a ficar, entendeu, mais } \\
\text { revoltadas, a brigar mais, porque elas começam a ver as } \\
\text { necessidades que são as vezes coisas bem pequenas e } \\
\text { poderiam ter... não são coisas complexas. }\end{array}$ & $\begin{array}{l}\text { Unidade de Saúde } \\
\text { Secretária quer reunir com agentes, prefeito quer } \\
\text { reunir...Todo mundo jogando todas as energias pra o agente } \\
\text { de saúde e pra enfermeira do PACS. Tão botando a gente } \\
\text { pra rua todo dia, é isso (...). Cansaço! Não agüento mais de } \\
\text { tanta pirambeira (sic)! Subindo e descendo pirambeira e } \\
\text { fazendo tudo! E ai, o nível de cobrança tão grande! }\end{array}$ \\
\hline $\begin{array}{l}\text { Mas eu acho que até na nossa unidade de saúde eles (os } \\
\text { ACS) têm mudado alguma coisa lá dentro. Têm conseguido } \\
\text { devagarzinho... as pessoas assim... olham mais } \\
\text { entusiasmadas, já ficam mais assim, sabe? Antes era aquela } \\
\text { coisa... aquele marasmo, né? }\end{array}$ & $\begin{array}{l}\text { Conselheiros } \\
\text { Locais de Saúde } \\
\text { (representantes } \\
\text { dos trabalhadores } \\
\text { da saúde) }\end{array}$ \\
\hline
\end{tabular}




\section{Repercussões na população da área}

As repercussões sobre a população podem ser consideradas frágeis, como revelam as enunciações destacadas. Em dois grupos focais com usuários existiu referência ao trabalho dos ACS, expressos como "bom" principalmente pelo fato de estes atuarem nas residências e escolas (ver item.5.5.2.4 sobre Avaliação do PACS).

Quadro 24b - Repercussões na população da área

\begin{tabular}{|l|l|}
\hline \multicolumn{1}{|c|}{ Como é descrita } & Autor \\
\hline $\begin{array}{l}\text { E o pessoal (ACS) é reconhecido..., quer dizer, a } \\
\text { comunidade está tendo uma referência. Sabendo que } \\
\text { tá, pelo menos, sendo atendido né? Pode ser que } \\
\text { eles não tenham um atendimento ideal. Tem aquela } \\
\text { atenção de ir na casa, né? E eles (a população) estão } \\
\text { sentindo, é, como é que a gente diz, se sentindo } \\
\text { pessoa, gente, né? }\end{array}$ & \\
\hline $\begin{array}{l}\text { A única coisa nova que eu vi aparecer é esse curso } \\
\text { das agentes comunitárias, que elas vão na casa, na } \\
\text { escola, tá fazendo um trabalho de escovação, com a } \\
\text { balança na mão vai ver as crianças desnutridas, não } \\
\text { é? Tem um controle. Mas ainda é muito pouco. }\end{array}$ & \\
\hline
\end{tabular}

Podemos inferir que é possivel que exista uma maior valorização da atuação dos próprios ACS pela declarada insatisfação com os serviços de saúde no DSBRV expressada por conselheiros de saúde em avaliação realizada pelo Projeto UNI/BA (PROJETO UNI/BA 1999). As observações mostraram que esta insatisfação é agravada pelo longo tempo sem funcionamento de diversas unidades de saúde da área devido a reformas na estrutura física. 


\subsubsection{Avaliação do PACS}

A análise de avaliação do PACS surge espontaneamente nas enunciações e foi preparada com base na mesma técnica descrita anteriormente e apresentada em quadros agregados por autor da avaliação.

O objeto de atitude predominante na análise de avaliação sobre 0 PACS é a própria atuação dos ACS seguida do perfil deles. Tal fato é coerente com a visibilidade do PACS, que é dada pela atuação dos Agentes Comunitários.

Dentre os elementos discrepantes identificados podemos destacar na avaliação dos gerentes a qualidade negativa identificada pelo fato de os ACS trazerem problemas dificeis de serem resolvidos pelas unidades de saúde. Isso reflete a indefinição de papéis e de articulação entre os serviços e o trabalho dos ACS e reforça o aspecto do incômodo que o trabalho e presença dos ACS trazem para as unidades de saúde e para os trabalhadores.

Ao mesmo tempo que para os membros do Conselho Municipal de Saúde o PACS não responde aos problemas e necessidades locais, este é avaliado positivamente pelos usuários por resolver problemas individuais e imediatos como assegurar encaminhamento e acesso a serviços na própria rede básica de saúde e dar uma atenção diferenciada pelo fato de ir até a casa do usuário.

Para os trabalhadores são contraditórias as duas avaliações sobre o desempenho: a positividade do desempenho do ACS está no fato de que estes estão "olhando horário de médico, anotando tudo" e é considerado negativo por reconhecer certo isolamento no trabalho, confirmado na expressão "mas a gente só não faz nada". 
Quadro 25 - Análise avaliativa do PACS por Conselheiros Locais de Saúde representantes da comunidade, DSBRV, 1999

\begin{tabular}{|c|c|c|c|c|}
\hline Como é descrita & $\begin{array}{c}\text { Objeto de } \\
\text { atitude }\end{array}$ & \begin{tabular}{|c|}
$\begin{array}{c}\text { Conector } \\
\text { verbal }\end{array}$ \\
\end{tabular} & $\begin{array}{c}\text { Termo } \\
\text { avaliativo }\end{array}$ & \begin{tabular}{|c|}
$\begin{array}{c}\text { Resultado da } \\
\text { avaliação }\end{array}$ \\
\end{tabular} \\
\hline $\begin{array}{l}\text { Só sai na televisão, como saiu agora, o governo: "os agentes de } \\
\text { saúde!" Os agentes de saúde tá atendendo quase ninguém! Um } \\
\text { Nordeste grandão, como nós vimos as dificuldades pra atender quanto? } \\
\text { É } 30 \% \text { ? Como é que vocé atende } 30 \% \text { de uma população?, os } 70 \% \\
\text { não sabe o que é nada. E vai pra televisão parecendo que é } 100 \% \text {, } \\
\text { porque o que aparece na televisão é } 100 \% \text { de pessoas que é visitado } \\
\text { pela agente de saúde, que tá bom. }\end{array}$ & $\begin{array}{l}\text { Cobertura do } \\
\text { PACS }\end{array}$ & $\begin{array}{l}\text { Está } \\
\text { Atendend } \\
0\end{array}$ & Quase ninguém & $\begin{array}{l}\text { Desempenho } \\
\text { negativo }\end{array}$ \\
\hline $\begin{array}{l}\text { O PACS, se não tem lá as enfermeiras treinadas pelo UNI (Projeto } \\
\text { coordenado pela universidade em parceria com comunidade local e } \\
\text { serviços de saúde e atuante na área), se não tem a gente pressionando } \\
\text { lá de alguma forma é um caos. A gente chega a falar que os agentes } \\
\text { comunitários tão simplesmente parados lá dentro de uma sala lá, } \\
\text { porque quando o UNI tá nessa pressão, nessa negociação, tal, as } \\
\text { coisas andam; quando não tá, a coisa parece que... não sabe o rumo } \\
\text { que vai, não sabe... não há geréncia, não há gestão. }\end{array}$ & $\begin{array}{l}\text { Organização } \\
\text { do PACS }\end{array}$ & Há & $\begin{array}{l}\text { Caos } \\
\text { Sem gerência }\end{array}$ & $\begin{array}{l}\text { Qualidade } \\
\text { negativa } \\
\text { Desempenho } \\
\text { negativo }\end{array}$ \\
\hline $\begin{array}{l}\text { E como o PACS no início lá na unidade. Botaram o pessoal pra fazer, } \\
\text { começar a ir nas ruas e de repente chegou, teve uma reunião e eu } \\
\text { participei dessa reunião e um grupo lá de agentes comunitários veio } \\
\text { com uma relação de ruas que estavam com problemas de saneamento } \\
\text { básico, lixo, a infra-estrutura. Eu disse: "meu amigo...eu já conhecia, eu } \\
\text { conheço o problema"; mas... será que é esse o trabalho do agente } \\
\text { comunitário, é fazer esse levantamento? Esse levantamento o lider } \\
\text { comunitário já tem, já fez, deu entrada... já não tem mais aonde ir } \\
\text { porque todo local, todas as secretarias que vocé pede a coisa dá no } \\
\text { mesmo. }\end{array}$ & $\begin{array}{l}\text { Atuação do } \\
\text { ACS }\end{array}$ & É fazer & Levantamento & $\begin{array}{l}\text { Desempenho } \\
\text { negativo }\end{array}$ \\
\hline
\end{tabular}

Ealanço: Com desempenho negativo quanto à sua cobertura, condução e atuação e com registro de qualidade negativa na sua organização o PACS é avaliado negativamente pelos conselheiros de saúde representantes da comunidade. 


\begin{tabular}{|c|c|c|c|c|}
\hline Como é descrita & $\begin{array}{l}\text { Objeto de } \\
\text { atitude }\end{array}$ & $\begin{array}{l}\text { Conector } \\
\text { verbal }\end{array}$ & $\begin{array}{c}\text { Termo } \\
\text { avaliativo }\end{array}$ & $\begin{array}{c}\text { Resultado } \\
\text { da } \\
\text { avaliaçăo } \\
\end{array}$ \\
\hline $\begin{array}{l}\text { Mas então, os agentes comunitários têm ido nas casas das pessoas, têm } \\
\text { ido aos bairros, aos locais, a precariedade das condições de saúde se } \\
\text { coloca mais evidente, das condições de vida de sobrevivência da } \\
\text { população de Salvador, e têm trazido (ênfase) demandas, esses } \\
\text { problemas para as unidades de saúde. E colocado à mostra que o } \\
\text { serviço de saúde não tem condição de... no que é sua competência para } \\
\text { resolver, não tem condição de resolver. }\end{array}$ & $\begin{array}{l}\text { Atuação dos } \\
\text { ACS }\end{array}$ & $\begin{array}{l}\text { Têm } \\
\text { Levantando/ } \\
\text { Trazido }\end{array}$ & \begin{tabular}{|l|} 
Muito \\
problemas \\
desconside \\
rados
\end{tabular} & $\begin{array}{l}\text { Qualidade } \\
\text { positiva }\end{array}$ \\
\hline $\begin{array}{l}\text { Se cria uma expectativa na população de que a Secretaria da Saúde está } \\
\text { enviando o serviço de saúde na casa, na residência das pessoas para } \\
\text { resolver os problemas e a realidade é completamente outra. É mais uma } \\
\text { enganação (ri), uma mentira dessa gestão de criar uma expectativa falsa } \\
\text { nas pessoas. Primeiro que vai mudar modelo assistencial, que a partir } \\
\text { das informações dos agentes comunitários se repensaria o modelo, se } \\
\text { implantaria, primeiro priorizando aquelas microáreas, os } 30 \% \text { da } \\
\text { população que foi definido como integrantes... os privilegiados para } \\
\text { serem adotados pelos agentes comunitários (tom irônico e de riso), tudo } \\
\text { seria resolvido desses } 30 \% \text { e nem esses } 30 \% \text { tão tendo o mínimo do que } \\
\text { se poderia esperar. (...). }\end{array}$ & $\begin{array}{l}\text { Caracteristic } \\
\text { as do PACS }\end{array}$ & Estão tendo & $\begin{array}{l}\text { Descolado } \\
\text { da } \\
\text { realidade }\end{array}$ & $\begin{array}{l}\text { Desempenho } \\
\text { negativo }\end{array}$ \\
\hline
\end{tabular}

Balanço: Para os membros do CMS o desempenho do PACS também é negativo, o que se coaduna com uma qualidade também considerada negativa, que é a de não atender aos reais problemas de saúde da população local. É destacado como qualidade positiva apenas o fato de que com o trabalho do ACS se revela problemas antes não considerados pelos serviços de saúde e outras entidades. 
Quadro 25b - Análise avaliativa do PACS por Trabalhadores da Saúde, DSBRV, 1999

\begin{tabular}{|c|c|c|c|c|}
\hline Como é descrita & $\begin{array}{c}\text { Objeto de } \\
\text { atitude }\end{array}$ & $\begin{array}{c}\text { Conector } \\
\text { verbal }\end{array}$ & $\begin{array}{c}\text { Termo } \\
\text { avaliativo }\end{array}$ & $\begin{array}{c}\text { Resultado } \\
\text { da avaliaçāo }\end{array}$ \\
\hline $\begin{array}{l}\text { Apesar de muito avanço, muita melhora de tudo (com ironia), } \\
\text { ainda é muito pouco, porque falta isso que eu acho que todo } \\
\text { mundo talvez concorde comigo... falta muito, apesar de um } \\
\text { bom trabalho, a gente é... que a gente é muito importante pra } \\
\text { todos os grupos; os grupos têm um interesse grande, que a } \\
\text { gente vai fazer muita coisa, mas a gente só não faz nada. }\end{array}$ & $\begin{array}{l}\text { Atuação do } \\
\text { ACS }\end{array}$ & $E$ & Muito pouco & $\begin{array}{l}\text { Desempenho } \\
\text { negativo }\end{array}$ \\
\hline $\begin{array}{l}\text { Apesar que o nosso trabalho é de orientação às familias, mas } \\
\text { nós chegamos lá encontramos fome... é... desemprego, } \\
\text { é...estrutura... falta de higiene, é estrutura também da rua, de } \\
\text { saneamento básico e outras necessidades básicas que não } \\
\text { tem. A gente sabe, a gente pensa assim, além desse trabalho } \\
\text { nosso, pra que isso dê certo, pra saúde melhorar realmente, } \\
\text { depende de muito mais pessoas que não estão realmente } \\
\text { envolvidas no trabalho (tom de crítica). }\end{array}$ & & Depende & $\begin{array}{l}\text { Muitas pessoas } \\
\text { não envolvidas }\end{array}$ & $\begin{array}{l}\text { Qualidade } \\
\text { negativa }\end{array}$ \\
\hline $\begin{array}{l}\text { Estão olhando horário de médico, anotando tudo, vendo o } \\
\text { horário, se o médico não vem, se tá faltando. Chegam pra mim } \\
\text { mesmo e diz: "Olha, dr. fulano não tá vindo na unidade; dr. } \\
\text { fulano só anda de licença!" Uma critica mesmo. Eles, assim, } \\
\text { relatando mesmo. Eles quem? Os agentes, os agentes. }\end{array}$ & & $\begin{array}{l}\text { Estão } \\
\text { Está }\end{array}$ & $\begin{array}{l}\text { Olhando horário } \\
\text { de médico } \\
\text { Anotando tudo } \\
\text { Relatando mesmo }\end{array}$ & $\begin{array}{l}\text { Desempenho } \\
\text { positivo }\end{array}$ \\
\hline
\end{tabular}

Balanço: para os trabalhadores da saúde a avaliação de desempenho do PACS se anula e a qualidade identificada é negativa. 
Quadro 25c — Análise avaliativa do PACS por Gerentes de Unidades de Saúde, DSBRV, 1999

\begin{tabular}{|c|c|c|c|c|}
\hline Como é descrita & $\begin{array}{c}\text { Objeto de } \\
\text { atitude }\end{array}$ & $\begin{array}{c}\text { Conector } \\
\text { verbal }\end{array}$ & $\begin{array}{c}\text { Termo } \\
\text { avaliativo }\end{array}$ & $\begin{array}{l}\text { Resultado da } \\
\text { avaliação }\end{array}$ \\
\hline $\begin{array}{l}\text { Inclusive que eles estão assim, com muita consciência do } \\
\text { valor que eles têm. Pelo menos os que trabalham aqui na } \\
\text { área, os sete, eles colocam muito pra gente que eles são } \\
\text { da comunidade, mas também profissionais de saúde, e } \\
\text { não estão fazendo favor nenhum a gente, fazendo favor } \\
\text { nenhum a eles, e ele vir e cobrar da gente o atendimento. }\end{array}$ & Perfil do ACS & Estão & $\begin{array}{l}\text { Consciência do } \\
\text { valor }\end{array}$ & $\begin{array}{l}\text { Qualidade } \\
\text { positiva }\end{array}$ \\
\hline $\begin{array}{l}\text { O grupo de agentes comunitários aqui é um grupo bom, } \\
\text { interessado, atuante e tem, estabeleceu uma relação muito } \\
\text { boa com o serviço, de fato, como deve ser, de tirar os } \\
\text { pacientes, a comunidade, praqui pro serviço. }\end{array}$ & $\begin{array}{l}\text { Atuação dos } \\
\text { ACS }\end{array}$ & Estabeleceu & $\begin{array}{l}\text { Interessado } \\
\text { Atuante } \\
\text { Relação muito boa }\end{array}$ & $\begin{array}{l}\text { Desempenho } \\
\text { positivo } \\
\text { Qualidade } \\
\text { Positiva }\end{array}$ \\
\hline $\begin{array}{l}\text { (...) porque hoje o PACS, ele tá indo pra comunidade. } \\
\text { Então ele tá indo no local onde tá o sofrimento mesmo e } \\
\text { sabendo o motivo daquela pessoa não poder chegar até } \\
\text { aqui, vê o que as pessoas estão sofrendo e a tentativa de } \\
\text { solucionar. (...). Então realmente o PACS é uma coisa que } \\
\text { tá dando um respaldo muito grande, mas ao mesmo tempo } \\
\text { tem essas questões deles estarem trazendo coisas que } \\
\text { ainda tá sendo difícil da gente de resolver, de solucionar. }\end{array}$ & & $\begin{array}{l}\text { Sabendo } \\
\text { Está } \\
\text { Dando } \\
\text { Trazendo }\end{array}$ & $\begin{array}{l}\text { Do sofrimento (da } \\
\text { população) } \\
\text { Respaldo muito } \\
\text { grande } \\
\begin{array}{l}\text { Coisas difíceis de } \\
\text { resolver }\end{array}\end{array}$ & $\begin{array}{l}\text { Qualidade } \\
\text { positiva } \\
\text { Desempenho } \\
\text { positivo } \\
\text { Qualidade } \\
\text { negativa }\end{array}$ \\
\hline
\end{tabular}

Balanço: Com desempenho positivo e qualidades predominantes também positivas o PACS só é avaliado negativamente pelos gerentes por trazer aos serviços problemas considerados difíceis de resolver neste nivel de atenção. 
Quadro 25d - Análise avaliativa do PACS por membros da Coordenação do DSBRV, 1999

\begin{tabular}{|c|c|c|c|c|}
\hline Como é descrita & Objeto de atitude & Conector verbal & Termo avaliativo & $\begin{array}{c}\text { Resultado da } \\
\text { avaliação }\end{array}$ \\
\hline $\begin{array}{l}\text { Os agentes comunitários expressaram } \\
\text { insatisfação com o papel deles durante a } \\
\text { reunião com o prefeito. Também } \\
\text { comentavam entre eles e comigo durante } \\
\text { a reunião. }\end{array}$ & Papel dos ACS & Expressaram & Insatisfação & Qualidade negativa \\
\hline $\begin{array}{l}\text { O PACS está numa fase de... nós fizemos } \\
\text { uma avaliação agora, e tivemos alguns } \\
\text { avanços. (...) A comunidade solicita o } \\
\text { agente e este tem uma outra noção do } \\
\text { que é saúde pública, diferente da do } \\
\text { começo. }\end{array}$ & $\begin{array}{l}\text { Resultados do } \\
\text { PACS } \\
\text { Perfil do ACS }\end{array}$ & $\begin{array}{l}\text { Tivemos } \\
\text { Tem }\end{array}$ & $\begin{array}{l}\text { Avanços } \\
\text { Outra } \\
\text { noção/diferente }\end{array}$ & $\begin{array}{l}\text { Desempenho } \\
\text { positivo } \\
\text { Qualidade positiva }\end{array}$ \\
\hline
\end{tabular}

Balanço: Para os membros da coordenação do distrito sanitário o desempenho do PACS é positivo ainda que não se expressem claramente quais os elementos que contribuem para tanto. Quanto aos aspectos de qualidade, estes se anulam, existindo um reconhecimento de qualidades positivas e negativas no papel dos ACS. 
Quadro 25e - Análise avaliativa do PACS por Usuários, DSBRV, 1999

\begin{tabular}{|c|c|c|c|c|}
\hline Como é descrita & Objeto de atitude & Conector verbal & Termo avaliativo & $\begin{array}{l}\text { Resultado da } \\
\text { avaliação }\end{array}$ \\
\hline $\begin{array}{l}\text { Eu tô gostando é do trabalho daquele } \\
\text { pessoal que tá indo de casa em casa, acho } \\
\text { que é o pessoal (hesita).... (outro } \\
\text { participante completa) do agente } \\
\text { comunitário. Poxa, eu tô achando o trabalho } \\
\text { deles ótimo. }\end{array}$ & Atuação do ACS & $\begin{array}{l}\text { Estou } \\
\text { É }\end{array}$ & $\begin{array}{l}\text { Gostando } \\
\text { Otimo }\end{array}$ & $\begin{array}{l}\text { Desempenho } \\
\text { positivo }\end{array}$ \\
\hline $\begin{array}{l}\text { Agora, esse projeto que teve ai dessas } \\
\text { meninas, também nos ajudou muito. Vou } \\
\text { falar a verdade. Lá embaixo tem uma } \\
\text { menina que trabalha no projeto, aqui na } \\
\text { Santa Cruz, que ela... como é o nome desse } \\
\text { projeto ai das meninas? das meninas da } \\
\text { dengue, né? (outro participante responde) } \\
\text { Agente Comunitário. Esse projeto foi muito } \\
\text { bom, vamos falar a verdade, porque lá na } \\
\text { rua mesmo a menina de Maura, ela se } \\
\text { interessa, ela vem, coitada, pega cartão e } \\
\text { sobe e arranja remédio, oi, se vira. }\end{array}$ & & Foi & Muito bom & $\begin{array}{l}\text { Desempenho } \\
\text { positivo }\end{array}$ \\
\hline
\end{tabular}

Balanço: para os usuários o desempenho dos ACS é considerado positivo referindo-se apenas ao fato de que eles facilitam o acesso a outros serviços. 


\subsubsection{Comentários finais}

Afirmar uma contradição entre a identificação do PACS como inovação e sua avaliação é um risco. É deixar-se levar pelas aparências. De início vale lembrar que a inovação identificada foi o espaço de ação do PACS e em certa medida o "burburinho" que a presença dos agentes tem causado no território do DSBRV. Se relembrarmos os autores da identificação dessa inovação, que são: conselheiros locais de saúde representantes dos trabalhadores; trabalhadores da saúde; gerentes de unidades de saúde e usuários, vemos que autoria e resultado da avaliação guardam coerência. Digno de nota é o fato de essa inovação ter sido a única identificada pelos usuários, o que confirma a distância, em repercussão, das demais inovações identificadas com eles.

A inovação "espaço de ação do PACS" guarda relação com a definição da inovação como tática do cotidiano - é assim que esse espaço é ocupado pelos conselheiros locais de saúde representantes da comunidade - agregando ao trabalho dos CLS uma articulação do próprio trabalho dos Agentes Comunitário, que têm um acesso direto à população local excluída. Esta inovação é também conseqüência da "ocupação política" do PACS pelos conselheiros locais de saúde representantes da comunidade, cujo papel de destaque na seleção dos Agentes e no acompanhamento do Programa pode ser observado durante o trabalho de campo.

Para os trabalhadores da saúde a inovação PACS se limita à criação do novo, no caso de uma atividade "de fora", "estranha" aos serviços de saúde e com certo poder de "sacudir o marasmo e de fazer pressão" sobre eles. 


\subsubsection{Inovação: o trabalho em parceria no Projeto UNI/Bahia}

\subsubsection{Premissas}

O Projeto UNI/Bahia é parte do Programa UNI (que desenvolveu estes projetos na América Latina, sendo cinco no Brasil), financiado pela Fundação Kellogg, e esteve em atividade de novembro de 1994 a junho de 2001. Dentre seus objetivos estão a promoção de mudanças nos modelos de atenção e de ensino das profissões da saúde e apoiar o controle social do sistema de saúde no espaço territorial do Distrito Sanitário Barra/Rio Vermelho, no municipio de Salvador. Com base em um ideário ${ }^{14}$ apoiado na parceria entre formadores das profissōes de saúde, serviços de saúde e comunidades em seu entorno, a estratégia de intervenção adotada pelo Projeto UNI se dá através de problemas de saúde, priorizados em função de sua magnitude, transcendência e factibilidade de intervenção. São parceiros no Projeto as Escolas de Enfermagem, Nutrição e de Medicina Veterinária; as Faculdades de Medicina, Odontologia, Farmácia, Departamento de Psicologia e o Instituto de Saúde Coletiva e Instituto de Ciências da Saúde da Universidade Federal da Bahia; os serviços públicos de saúde do DSBRV e as organizações comunitárias da área.

\subsubsection{A parceria como inovação}

O Projeto UNI/BA, através de uma das suas estratégias - a de parceria entre diferentes grupos atuantes no distrito sanitário: grupos organizados da população; os serviços locais de saúde e professores e alunos dos sete cursos de saúde da Universidade Federal da Bahia -, possibilitou a existência de um movimento que é destacado na sua

\footnotetext{
${ }^{14}$ Para interessados no ideário UNI ver. Kisil M, Chaves M, (organizadores). Programa UNI: Uma nova iniciativa na educação dos profissionais de saúde. Battle Creek: Fundação Kellogg; 1994 e Almeida M, Feuerwerker L, Llanos M, (organizadores). Educação dos profissionais de saúde na América Latina. Teoria e prática de um movimento de mudança. São Paulo: Hucitec; Buenos Aires: Lugar Editorial; Londrina: Ed.UEL; 1999.
} 
identificação como uma inovação na gestão da saúde. Esta junção de esforços - principalmente da universidade e da comunidade - tem "provocado um encontro" entre segmentos diferentes em torno de um interesse comum: a saúde.

O significado, dado pelos Conselheiros Locais de Saúde representantes da comunidade, do Projeto UNI/BA como uma inovação no DSBRV:

Então, quando a gente fala no Projeto UNI não é o projeto UNI enquanto instituição. É essa idéia, essa concepção, essa concepção. A idéia, a concepção de juntar três parceiros (refere-se à Universidade Federal da Bahia/UFBA, serviços de saúde e comunidade local) (Grupo focal com conselheiros locais de saúde representantes da comunidade)

$\mathrm{Na}$ análise dessa inovação, foram considerados os achados nas entrevistas realizadas com membros da direção executiva do Projeto.

Para melhor compreender o Projeto UNI/BA enquanto inovação na gestão da saúde, apresentamos nos quadros abaixo as enunciaçōes relacionadas com as características da inovação analisada. 
Quadro 26 - O Projeto UNI/BA como espaço de desenvolvimento e fortalecimento de parcerias

\begin{tabular}{|c|c|}
\hline Como é descrito & Autor \\
\hline $\begin{array}{l}\text { A comunidade sozinha não pode, tem coisas que } \\
\text { ela não pode resolver. Eu acho que essa parceria } \\
\text { também tem... uma coisa que eu tava } \\
\text { esquecendo, a parceria, Universidade/serviço/ } \\
\text { comunidade, eu acho que é uma coisa assim } \\
\text { inovadora, que vem fortificando, né?, fortalecendo } \\
\text { toda a caminhada nossa, não só como } \\
\text { conselheiros mas como pessoas que atuam na } \\
\text { comunidade. }\end{array}$ & \begin{tabular}{|lr} 
Conselheiros & Locais \\
de & Saúde \\
(representantes & da \\
comunidade) & \\
\end{tabular} \\
\hline $\begin{array}{l}\text { Só em relação ao papel do UNI, quando a gente } \\
\text { fala em UNI não é o UNI como instituição, mas é } \\
\text { os fatores, esse ambiente que o UNI criou que é a } \\
\text { parceria entre comunidade e Universidade. Há } \\
\text { formalmente o serviço e há uma certa vantagem } \\
\text { nisso porque dentro do próprio serviço, do próprio } \\
\text { governo existe também, como existe na } \\
\text { Universidade, como existe na comunidade, } \\
\text { algumas pessoas que são sensíveis: são técnicos } \\
\text { que estão angustiados pela ineficácia, pela } \\
\text { incompetência e tal da coisa e até mesmo que } \\
\text { têm, alguns, compromissos politicos. Essa } \\
\text { parceria cria também a possibilidade, mesmo que } \\
\text { a instituição de serviço não funcione, não assimile } \\
\text { a estória da parceria mesmo, cria a possibilidade } \\
\text { de atrair essa turma do serviço mais } \\
\text { comprometida também pra esse grupo. }\end{array}$ & \\
\hline
\end{tabular}


Quadro 26a - O Projeto UNI/BA como espaço de atuação de grupos com compromisso político com a saúde

\begin{tabular}{|l|l|}
\hline \multicolumn{1}{|c|}{ Como é descrito } & \multicolumn{1}{|c|}{ Autor } \\
\hline $\begin{array}{l}\text { Então por isso que a gente afirma aqui que essa } \\
\text { iniciativa inovadora do UNI é resultado... desse } \\
\text { vínculo da Universidade, mesmo precária, mesmo } \\
\text { assistemático e tal é resultado do papel do UNI; e } \\
\text { dentro do UNI aquelas pessoas comprometidas } \\
\text { politicamente da Universidade, mesma coisa que } \\
\text { tem na comunidade, nos conselhos: só funciona, só } \\
\text { existe, porque existe alguma minoria de pessoas, } \\
\text { felizmente, né, dentro dessas instituições, dessas } \\
\text { escolas que ainda têm compromisso político e } \\
\text { social, com essa visão que também náde } \\
\text { comunidade) } \\
\text { uniforme; cada um tem suas limitações em ver... } \\
\text { não há ainda um corpo politico assim... }\end{array}$ \\
$\begin{array}{l}\text { Eu não sei se todos tiveram a oportunidade de } \\
\text { conhecer, mas como eu já participei de outras } \\
\text { reuniōes, eu entendi também que antes desse } \\
\text { programa todo de saúde existir (refere-se ao } \\
\text { PACS), que nós estamos fazendo parte, esse UNI, } \\
\text { junto com o Conselho Local, tem lutado muito. }\end{array}$ \\
\hline
\end{tabular}


Quadro 26b - O Projeto UNI/BA como espaço de articulação e ações na rede de serviços de saúde

\begin{tabular}{|l|l|}
\hline \multicolumn{1}{|c|}{ Como é descrito } & \multicolumn{1}{|c|}{ Autor } \\
\hline $\begin{array}{l}\text { Mas desde que a gente começou a parceria com } \\
\text { o distrito, né?, através do Projeto (refere-se ao } \\
\text { Projeto UNI/BA) que é, é alguma coisa eu acho } \\
\text { que realmente funcionava, ou seja, a coisa } \\
\text { principal foi fazer com que houvesse uma é..., } \\
\text { até mesmo o próprio processo de discussão que } \\
\text { antes não havia, não é? entre as diversas } \\
\text { unidades e entre a gente e o distrito como um } \\
\text { todo, e a gerência do distrito (enfatiza a última de } \\
\text { frase, como dizendo que com a gerência a } \\
\text { relação era ainda mais distante). Porque a partir } \\
\text { disso daí a gente pode fazer todas aquelas } \\
\text { oficinas pra fazer o planejamento e tal. }\end{array}$ & \\
\hline $\begin{array}{l}\text { O Projeto UNI, não é puxando o saco, não é } \\
\text { nada disso, é que de fato, ele nos ajudou muito! } \\
\text { Até no relacionamento com as unidades, com os } \\
\text { diretores. Foram as reuniōes de CEDES } \\
\text { (Comissão Executiva do Distrito Sanitário), com } \\
\text { fulana (cita o nome da ex-coordenadora do } \\
\text { distrito sanitário), com o Projeto UNI que de fato } \\
\text { nos aproximou bastante dos centros de saúde. } \\
\text { Uma coisa que eu sinto que nós perdemos. Não, } \\
\text { sabe, nós perdemos muito essa ligação. }\end{array}$ & \\
\hline $\begin{array}{l}\text { Passamos a ter reuniões de CEDES dinàmicas, } \\
\text { com pauta, com organização, com comida } \\
\text { (enfática), que era o que as pessoas gostavam } \\
\text { muito também; com discussões, com trabalhos. } \\
\text { Hoje em dia a gente perdeu muito isso, essas } \\
\text { reuniões de CEDES tão muito vazias, tão muito } \\
\text { desorganizadas (diminui o tom de voz). }\end{array}$ & \\
\hline
\end{tabular}




\subsubsection{Repercussões}

O Projeto UNI/BA está sempre referido em todas as enunciaçōes e relacionado com todas as inovaçōes identificadas. No desenvolvimento deste Projeto criaram-se, sem dúvida, espaços de ampliação do poder, principalmente dos participantes vinculados à Universidade Federal da Bahia/UFBA e setores organizados da população local.

Considerando o contexto politico local, não é excepcional que a condução dada pela direção do Projeto UNI/BA tenha permitido o surgimento de sérios conflitos com a SMS, que dentre outros resultados impediu uma maior participação dos serviços de saúde nas suas atividades. Antes de identificar e comentar as repercussões dessa inovação no território DSBRV apresentamos algumas enunciaçōes que apontam os problemas entre a condução do Projeto UNI/BA e a SMS, representada pela Coordenação do DSBRV. Formalmente, no entanto, a SMS continuou parceira do Projeto, inclusive fazendo parte da sua direção. 
Imagem: O Projeto UNI/BA como ameaça

\begin{tabular}{|c|c|}
\hline Como é descrita & Autor \\
\hline $\begin{array}{l}\text { Dentro do próprio Conselho Local de Saúde já surgiram } \\
\text { várias questōes - "Venha cá, o UNI... por que o UNI só } \\
\text { fica lá no Distrito Sanitário Barra/Rio Vermelho? Por que } \\
\text { o UNI não vai pra outro Distrito?". Os membros do } \\
\text { Conselho Municipal, o pessoal tá cobrando. (...). Então, } \\
\text { quer dizer, as pessoas, o próprio Conselho Local de } \\
\text { Saúde ou o próprio Conselho Municipal de Saúde } \\
\text { quando viu, assim, quando viu algumas instituições se } \\
\text { mobilizando e indo pra o Conselho Municipal de Saúde } \\
\text { para justamente reforçar alguns critérios, que até então } \\
\text { não tinham no Conselho Municipal de Saúde, para } \\
\text { contratação dos agentes comunitários e eles já } \\
\text { começaram a ver o UNI como força... E aí a secretária } \\
\text { (refere-se à secretária municipal da saúde) viu o UNI de } \\
\text { uma forma diferente, de uma forma que era um perigo } \\
\text { para o governo. }\end{array}$ & $\begin{array}{l}\text { Conselheiros } \\
\text { Locais de Saúde } \\
\text { (representantes } \\
\text { da comunidade) }\end{array}$ \\
\hline $\begin{array}{l}\text { O que eu tenho medo é o distrito perder a parceria com } \\
\text { o Projeto UNI. Eu sinto muita pressão, muita mesmo } \\
\text { (refere-se aos seus anseios quanto às pressões que } \\
\text { recebem para não aceitar a colaboração de pessoas } \\
\text { vinculadas ao Projeto, em especial da UFBA). }\end{array}$ & $\begin{array}{ll}\text { Membro da } \\
\text { Coordenação do } \\
\text { DSBRV }\end{array}$ \\
\hline $\begin{array}{l}\text { É bom que se diga que existe uma intolerância por parte } \\
\text { do executivo em relação a nossa participação nesse tipo } \\
\text { e ao próprio Projeto UNI, né? Existe uma intolerância } \\
\text { muito grande em relação a isso. Porque ele sabe que } \\
\text { essa nossa parceria no Projeto UNI dá uma outra } \\
\text { perspectiva aos moradores daquela localidade. }\end{array}$ & $\begin{array}{l}\text { Membro } \\
\text { Conselho } \\
\text { Municipal } \\
\text { Saúde }\end{array}$ \\
\hline $\begin{array}{l}\text { Com o controle do nivel central, o controle e o medo } \\
\text { incrivel de qualquer tipo de sucesso, qualquer tipo de } \\
\text { coisa boa acontecendo não ser atribuido à gestão formal } \\
\text { do nivel central (SMS), existe um certo pânico disso. E } \\
\text { isso já foi inclusive declarado. O medo de que este } \\
\text { distrito estar melhor porque tem a universidade. Isto não } \\
\text { pode ser. }\end{array}$ & $\begin{array}{l}\text { Ex-membro da } \\
\text { Coordenação do } \\
\text { DSBRV }\end{array}$ \\
\hline
\end{tabular}


Outro aspecto relevante é o fato de que todas as inovaçōes identificadas sofrem, de vários modos, influência das atividades do Projeto UNI/BA e não só são parte deste, como podem ser consideradas repercussōes criadas no espaço de articulação/negociação do Projeto.

As repercussões foram categorizadas segundo o teima-eixo do seu conteúdo: na gestāo do DSBRV; nas açōes e serviços de saúde e na organização/reorganização dos CLS.

Quadro 27 - Repercussões na gestão do DSBRV

\begin{tabular}{|c|c|}
\hline Como é descrita & Autor \\
\hline $\begin{array}{l}\text { A visão que eu tinha de distrito era uma coisa } \\
\text { assim, meio apagada. (...). O Barra/Rio Vermelho } \\
\text { nem tanto, porque eu acho que, de todos, sempre } \\
\text { foi privilegiado por causa do apoio da Universidade. } \\
\text { Ele sempre teve um papel mais definido. }\end{array}$ & \begin{tabular}{|ll} 
Membros & da \\
Coordenação & do \\
DSBRV &
\end{tabular} \\
\hline $\begin{array}{l}\text { Então, sob o ponto de vista da gestão pública, e até } \\
\text { mesmo pra questão da continuidade, o UNI leva } \\
\text { tecnologia, tem levado poucas, ou de forma } \\
\text { precária tem levado; não de uma forma sistemática, } \\
\text { mas tem levado. }\end{array}$ & \begin{tabular}{|lr} 
Conselheiros & Locais \\
de & Saúde \\
(representantes & da \\
comunidade) &
\end{tabular} \\
\hline $\begin{array}{l}\text { Se vocè quiser dizer que o DSBRV é o distrito mais } \\
\text { organizado de Salvador é porque ele tem o Projeto } \\
\text { UNI por trás, dando, né, essa assistência e tal, aí } \\
\text { eu acredito. }\end{array}$ & \\
\hline $\begin{array}{l}\text { O processo de gestão, por conta do UNI, ele } \\
\text { começou a ser aberto a vários outros atores de } \\
\text { vários segmentos. Na condução estavam alunos, } \\
\text { estavam professores, estava a comunidade e } \\
\text { estavam pessoas do serviço. Eu diria que estava } \\
\text { aberto mesmo, tinha influência mesmo. }\end{array}$ & $\begin{array}{l}\text { Membro da } \\
\text { Coordenação } \\
\text { Executiva do } \\
\text { UNI/BA }\end{array}$ \\
\hline
\end{tabular}

Em relação à gestão da saúde, o Projeto UNI tem uma influência reconhecida como abrangente mas com características indefinidas. Isso aparece nas expressōes utilizadas ao se referirem à esta influência como "papel mais definido" (do DSBRV em relação a outros distritos da cidade), 
"distrito mais organizado" ou "na introdução de tecnologia", mas sem que exemplos concretos tenham sido enunciados.

O fato do Projeto UNI/BA, enquanto sua direção executiva, ser reconhecido como um ator que geriu a saúde no distrito em momentos do passado é uma repercussão que pode ser considerada contrária aos objetivos do próprio Projeto, um dos quais é criar parcerias "para intervir nos serviços, no processo de trabalho e na organização" buscando "uma atenção à saúde que incluísse os excluidos e que fosse realmente em função de problemas concretos e reais para melhorar (a situação de saúde da população), isso tudo relacionado com as condições de vida" (Entrevista 2 com membro da diretoria executiva do Projeto UNI/BA). Portanto, substituir a gestão pública por incapacidade ou omissão desta repercute desfavoravelmente para o alcance dos objetivos do próprio Projeto, do qual a SMS é formalmente participante, e do princípio da parceria. 
Quadro 27a - Repercussões nas ações e serviços de saúde

\begin{tabular}{|l|l|}
\hline \multicolumn{1}{|c|}{ Como é descrita } & \multicolumn{1}{|c|}{ Autor } \\
\hline $\begin{array}{l}\text { De quem foi a idéia de fazer o planejamento em conjunto? Foi do Projeto UNI, não? Foi } \\
\text { discussão do Projeto UNI, naquelas discussões que tinha a comunidade e o serviço de saúde, foi } \\
\text { por ali. }\end{array}$ & $\begin{array}{l}\text { Conselheiros Locais de Saúde } \\
\text { (representantes } \\
\text { trabalhadores da saúde) }\end{array}$ \\
\hline $\begin{array}{l}\text { O que houve de avanço na questão de saúde, foi fruto dessa articulação do UNI, né, que a gente } \\
\text { faz parte; o que houve, tudo que houve até mesmo a questão dos agentes comunitários, da forma } \\
\text { que tá hoje, eu tenho a pretensão de achar que foi fruto da nossa intervenção (alguém ri), da } \\
\text { nossa intervenção, da nossa intervenção como um todo aqui (ri). }\end{array}$ & $\begin{array}{l}\text { Conselheiros Locais de Saúde } \\
\text { (representantes da comunidade) }\end{array}$ \\
\hline $\begin{array}{l}\text { Outra coisa que eu esqueci de destacar nessa unidade é que a Universidade tá dentro da } \\
\text { unidade. A gente tem, esse distrito tem, não só nessa unidade, mas no distrito como um todo tem } \\
\text { um aproveitamento, maior, eu acho, do que dos outros, porque também eu não convivo com } \\
\text { todos; mas eu sei que a gente tem um, uma coisa assim, diferenciada por ter a Universidade } \\
\text { participando das nossas atividades, né, isso é bom, tudo que a gente precisa. Isso ... eu mesmo } \\
\text { recorro o tempo todo (ri), vocé ter a possibilidade de cursos, tudo que vocé precisa, ter a } \\
\text { possibilidade de tá junto da Universidade e conseguir dela a resposta mesmo, como fazer isso, } \\
\text { como é que dá para estruturar tal serviço e tem esse apoio da Universidade, os professores } \\
\text { sempre dentro da unidade. }\end{array}$ & Gerente de Unidades de Saúde \\
\hline \begin{tabular}{l} 
As enfermeiras do PACS conseguiram se impor graças ao apoio do Projeto UNI. \\
\hline $\begin{array}{l}\text { O GT (Grupo de Trabalho) da mulher, que é um grupo de trabalho do Projeto UNI e do distrito } \\
\text { sanitário. A gente trabalha os problemas, problemas da mulher, do adolescente (...). }\end{array}$
\end{tabular} & Trabalhadores da Saúde \\
\hline
\end{tabular}


Em relação às ações e serviços de saúde as repercussões identificadas são de natureza diversa, porém mais concretas. Desde as tentativas de planejamento e programação local integrada com os segmentos participantes do Projeto a mudanças introduzidas em práticas de saúde, os únicos fatos observados como "sobreviventes" no momento do trabalho de campo foram a existência de um Grupo de Trabalho sobre a saúde da mulher, com atividades regulares e o próprio trabalho do PACS, principalmente quanto ao acompanhamento e assessoria da UFBA às enfermeiras do programa. Outra caracteristica das repercussōes é que estas se referem, geralmente, a um tempo passado. Isso significa que as repercussōes podem ser atribuidas a açōes e parcerias desenvolvidas anteriormente 
Quadro 27b - Repercussões na organização/reorganização dos CLS

\begin{tabular}{|c|c|}
\hline Como é descrita & Autor \\
\hline $\begin{array}{l}\text { Mesmo com, com essa idéia de algum dia o UNI for acabar } \\
\text { e não alterar o apoio da Universidade, eu acho que a } \\
\text { comunidade está bem armada de todas as informações que } \\
\text { teve ao longo desses anos pra desenvolver esse trabalho } \\
\text { na comunidade, independente da força que o UNI tá dando, } \\
\text { pra não perder justamente esse caminho que estamos } \\
\text { seguindo... Isso... de melhoria.... }\end{array}$ & \multirow[t]{2}{*}{$\begin{array}{l}\text { Conselheiros Locais } \\
\text { de Saúde } \\
\text { (representantes da } \\
\text { comunidade) }\end{array}$} \\
\hline $\begin{array}{l}\text { Embora mudou-se muito o conceito de trabalhar pela } \\
\text { comunidade desde que se formou os conselhos, são } \\
\text { parcerias... já com o Projeto UNI. São coisas já trabalhadas, } \\
\text { experiências novas que a própria comunidade não tinha } \\
\text { convivido (...). }\end{array}$ & \\
\hline $\begin{array}{l}\text { Me chama sim, talvez a presença do Projeto UNI no Distrito } \\
\text { esteja no centro, provoca esse encontro das entidades aqui } \\
\text { do bairro, né. Por exemplo, agora na Conferência, antes o } \\
\text { Distrito não se reunia pra discutir, isto é uma coisa também } \\
\text { muito positiva, uma coisa diferente. E também, por } \\
\text { exemplo, eu não sei como está nas outras unidades, no } \\
\text { Conselho Local de Saúde nos outros Distritos, assim, por } \\
\text { mais problemas que a gente tenha ainda, que a gente... } \\
\text { mas o fato de ter o Conselho Local, que eu acho que a } \\
\text { gente tem um papel a cumprir que também e tem que fazer } \\
\text { alguma coisa para... }\end{array}$ & $\begin{array}{l}\text { Conselheiros Locais } \\
\text { de Saúde } \\
\text { (representantes dos } \\
\text { trabalhadores da } \\
\text { saúde) }\end{array}$ \\
\hline $\begin{array}{l}\text { Acho que tudo isso e essa coisa de trabalhar a } \\
\text { subjetividade, ter trabalhado eles (refere-se às capacitaçōes } \\
\text { com conselheiros de saúde) enquanto gente tá mudando, } \\
\text { tem uma coisa nova, tem uma coisa distinta. Porque os } \\
\text { Conselhos, quando o UNI começou, tinhaConselhos } \\
\text { formados mas era tão burocrático... Porque eles não } \\
\text { sabiam por que estavam ali. O processo de seleção de } \\
\text { conselheiros, quer dizer, tinha discussão com a } \\
\text { comunidade inteira, o que era ser conselheiro, qual era seu } \\
\text { papel. }\end{array}$ & $\begin{array}{l}\text { Membro da } \\
\text { Coordenação } \\
\text { Executiva do Projeto } \\
\text { UNI/BA }\end{array}$ \\
\hline $\begin{array}{l}\text { Atribuo a melhor organização dos conselhos, melhor } \\
\text { funcionamento dos conselhos. Sem dúvida eles passaram a } \\
\text { funcionar com mais regularidade. Isso tá relacionado a um } \\
\text { processo de discussão, de capacitação e de apoio do } \\
\text { Projeto UNI aqui no Distrito Barra/Rio Vermelho. Essa é a } \\
\text { grande diferença em relação aos outros distritos. }\end{array}$ & $\begin{array}{l}\text { Membro do } \\
\text { Conselho } \\
\text { de Saúde }\end{array}$ \\
\hline
\end{tabular}


As repercussões relacionadas aos Conselhos Locais de Saúde são as que estão enunciadas de modo mais consistente. Isto é reforçado por ser atuante e permanente a articulação entre o segmento comunidade $e$ Universidade e são dentre os parceiros os que mais têm se beneficiado mutuamente das vivências e experibencias no processo.

\subsubsection{Avaliação do "espaço de parceria" no Projeto UNI/Bahia}

Utilizando os recursos da técnica de análise de avaliação (BARDIN 1977) apresentamos a seguir os quadros e os balanços resultantes da avaliação do "espaço de parceria" no Projeto UNI/BA.

Os objetos de atitude são variados e as discrepàncias apresentadas se destacam pela localização no tempo. Os objetos de atitudes avaliados no tempo passado o são quase sempre de forma positiva e negativamente no tempo presente. Isto reflete as dificuldades entre os parceiros do Projeto, principalmente com a participação formal mas não de fato do próprio DSBRV.

Objetos de atitude relacionados com os serviços de saúde são os que recebem quase sempre avaliação negativa ainda que haja reconhecimento sobre o impacto negativo que a ausência de atividades em parceria tem causado aos serviços de saúde. Isto reforça o aspecto de maior resistência encontrada por parte dos serviços de saúde no processo de parceria no Projeto UNI. 
Quadro 28 - Análise avaliativa do "espaço de parceria" no Projeto UNI/BA por Conselheiros Locais de Saúde representantes dos trabalhadores da saúde, DSBRV, 1999

\begin{tabular}{|c|c|c|c|c|}
\hline Como é descrita & Objeto de atitude & Conector verbal & Termo avaliativo & $\begin{array}{c}\text { Resultado da } \\
\text { avaliaçáo }\end{array}$ \\
\hline $\begin{array}{l}\text { Agora de positivo eu concordo com } \\
\text { Fulana que o Projeto UNI, né, as } \\
\text { reuniões que eu fui eu gostei bastante e } \\
\text { é um espaço bastante democrático, por } \\
\text { conta que outras associações têm } \\
\text { posição diferente, têm postura diferente, } \\
\text { quando chega lá a gente faz assim uns } \\
\text { confrontos, eu acho que isso é } \\
\text { enriquecedor pra todo mundo, a gente } \\
\text { consegue comparar e refletir. }\end{array}$ & $\begin{array}{l}\text { Disseminação de } \\
\text { informações e } \\
\text { trocas de } \\
\text { experiências }\end{array}$ & $\begin{array}{l}\text { E } \\
\text { Faz } \\
\text { Consegue }\end{array}$ & $\begin{array}{l}\text { Bastante } \\
\text { democrático } \\
\text { Enriquecedor } \\
\text { Comparar e } \\
\text { refletir }\end{array}$ & $\begin{array}{l}\text { Qualidade positiva } \\
\text { Desempenho } \\
\text { positivo }\end{array}$ \\
\hline $\begin{array}{l}\text { O Projeto Uni fazia um trabalho lá no } 15^{\circ} \\
\text { Centro... teve problemas também, com a } \\
\text { gerente... O Projeto UNI se afastou do } \\
15^{\circ} \text { Centro e ai o trabalho geral ficou } \\
\text { caido, caiu muito o trabalho do } 15^{\circ} \\
\text { Centro de Saúde. }\end{array}$ & $\begin{array}{l}\text { Impacto da } \\
\text { auséncia de } \\
\text { atividades } \\
\text { promovidas pelo } \\
\text { Projeto no } 15^{\circ} \\
\text { Centro de Saúde }\end{array}$ & $\begin{array}{l}\text { Teve } \\
\text { Ficou }\end{array}$ & $\begin{array}{l}\text { Problemas } \\
\text { Projeto se afastou } \\
\text { Caiu muito o } \\
\text { trabalho }\end{array}$ & $\begin{array}{l}\text { Desempenho } \\
\text { negativo }\end{array}$ \\
\hline
\end{tabular}

Balanço: O balanço da avaliação indica qualidade e desempenho positivos do Projeto UNI/Bahia na disseminação de informações e distingue o impacto negativo nos serviços por ter sido rompida a parceria no espaço do Projeto UNI/Bahia. 
Quadro 28a - Analıse avalıatıva do "espaço de parcerıa" no Projeto UNI/Ba por Conselneıros Locaıs de Saude representantes da comunidade, DSBRV, 1999

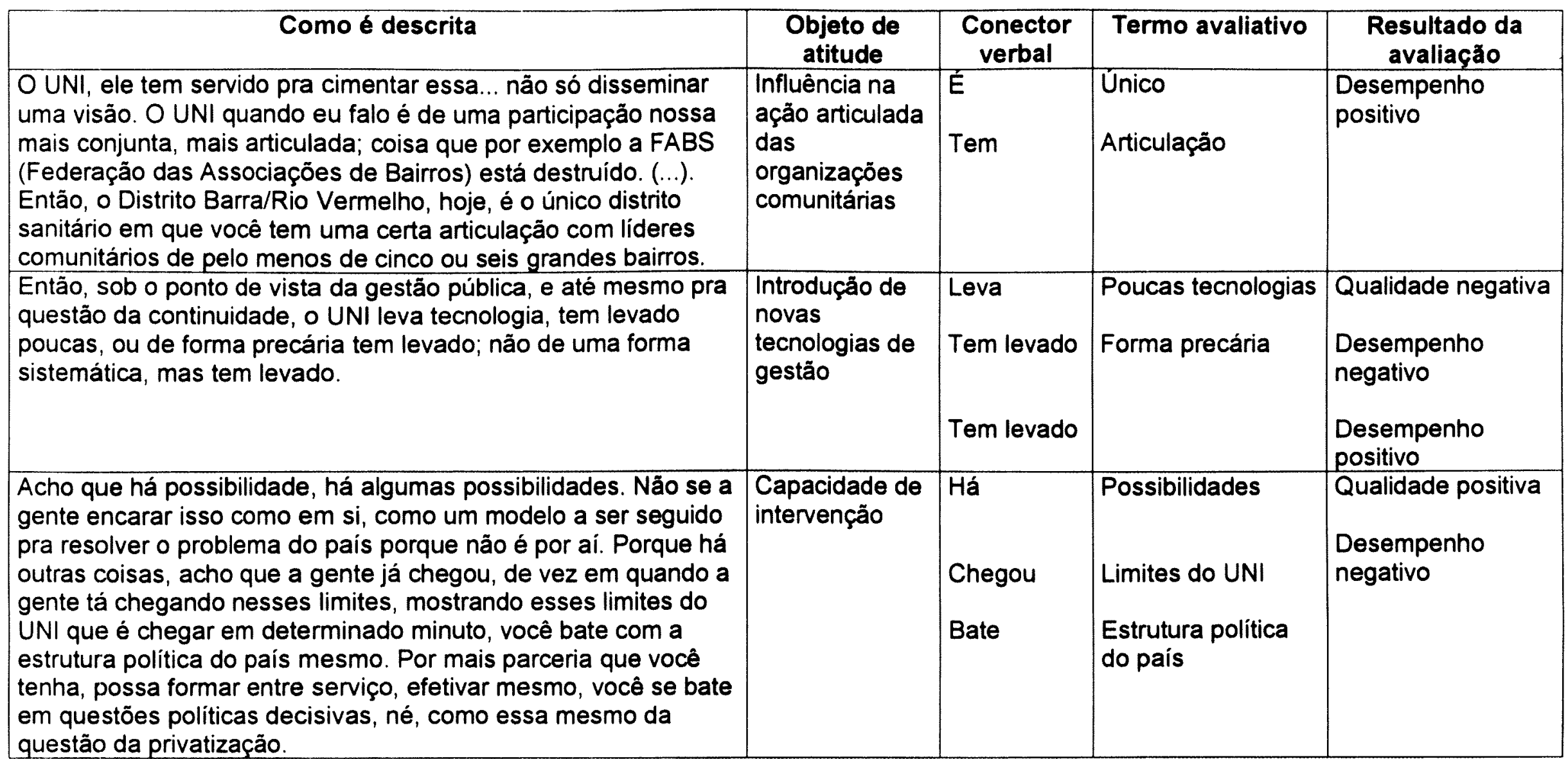

Balanço: a avaliação é favorável quanto ao desempenho, reconhecendo-se como negativos os próprios limites inerentes ao contexto político local. Quanto a qualidade é destacado como insuficiente o aporte de tecnologias para a gestão em saúde, coerente com toda a análise de ruptura da parceria com a rede de serviços de saúde nos últimos anos. 
Quadro 28b - Análise avaliativa do "espaço de parceria" no Projeto UNI/Ba por membros do Conselho Municipal de Saúde, DSBRV, 1999

\begin{tabular}{|c|c|c|c|c|}
\hline Como é descrita & $\begin{array}{c}\text { Objeto de } \\
\text { atitude }\end{array}$ & $\begin{array}{c}\text { Conector } \\
\text { verbal }\end{array}$ & $\begin{array}{c}\text { Termo } \\
\text { avaliativo }\end{array}$ & $\begin{array}{c}\text { Resultado da } \\
\text { avaliação }\end{array}$ \\
\hline $\begin{array}{l}\text { Do ponto de vista do serviço, né, e até da inserção da Universidade, } \\
\text { a gente tem muito pouco. Eu diria que nos serviços atualmente a } \\
\text { gente tem tido um refluxo. A gente tem tido um retrocesso e } \\
\text { principalmente sendo reflexo dessa centralização, desse } \\
\text { autoritarismo. O esforço do UNI no momento não tá sendo } \\
\text { aproveitado na sua totalidade e que poderia ser. Antes nós tínhamos } \\
\text { uma realidade um pouco diferente. Um pouco não, bem diferente! }\end{array}$ & $\begin{array}{l}\text { Desenvolvim } \\
\text { ento de } \\
\text { atividades } \\
\text { nos serviços } \\
\text { de saúde }\end{array}$ & $\begin{array}{l}\text { Tem tido } \\
\text { Tinhamos }\end{array}$ & $\begin{array}{l}\text { Refluxo } \\
\text { Retrocesso } \\
\text { Realidade } \\
\text { bem } \\
\text { diferente }\end{array}$ & $\begin{array}{l}\text { Desempenho } \\
\text { negativo (tempo } \\
\text { presente) } \\
\text { Desempenho } \\
\text { positivo (tempo } \\
\text { passado) }\end{array}$ \\
\hline $\begin{array}{l}\text { Eu acho que chegamos a ter, se a gente for pensar nas oficinas de } \\
\text { planejamento, que era um momento que se conseguia reunir } \\
\text { profissionais de saúde, pessoas da universidade, os interessados da } \\
\text { Universidade, professores que estavam inseridos no Projeto e } \\
\text { comunidade, a gente... comparando as oficinas de dois anos, três } \\
\text { anos atrás com os fóruns que se cria atualmente, a gente vê que há } \\
\text { uma queda muito grande de participação, de entusiasmo, de, de } \\
\text { vontade de investir, de fazer alguma coisa, de mudar. }\end{array}$ & $\begin{array}{l}\text { Articulação } \\
\text { dos } \\
\text { parceiros }\end{array}$ & $\begin{array}{l}\text { Vê } \\
\text { Há }\end{array}$ & $\begin{array}{l}\text { Queda de } \\
\text { participação } \\
\text { Queda de } \\
\text { entusiasmo }\end{array}$ & $\begin{array}{l}\text { Desempenho } \\
\text { negativo (tempo } \\
\text { presente) } \\
\text { Qualidade } \\
\text { negativa (tempo } \\
\text { presente) }\end{array}$ \\
\hline $\begin{array}{l}\text { Acho que aqui no Barra/Rio Vermelho a gente tem uma relação } \\
\text { diferenciada dos demais distritos. Acho que pelo fato da presença da } \\
\text { Universidade aqui no distrito e além disso, da presença e do } \\
\text { desenvolvimento do Projeto UNI aqui. }\end{array}$ & $\begin{array}{l}\text { Inter-relação } \\
\text { entre os } \\
\text { parceiros }\end{array}$ & Tem & $\begin{array}{l}\text { Relação } \\
\text { diferenciada }\end{array}$ & $\begin{array}{l}\text { Qualidade } \\
\text { positiva } \\
\text { Desempenho } \\
\text { positivo }\end{array}$ \\
\hline
\end{tabular}

Balanço: aparece um contraste muito interessante que contrapōe os aspectos de qualidade e desempenho no tempo: em relação ao passado são valorados positivamente e em relação ao presente o são negativamente. Isto mostra a situação atual, que se tem deteriorado nos últimos anos e que pode ser mais bem compreendida se relacionada com outros achados sobre esta inovação. 
Quadro 28c - Análise avaliativa do "espaço de parceria" no Projeto UNI/Ba por Trabalhadores da Saúde, 1999

\begin{tabular}{|c|c|c|c|c|}
\hline Como é descrita & $\begin{array}{c}\text { Objeto de } \\
\text { atitude }\end{array}$ & Conector verbal & Termo avaliativo & $\begin{array}{c}\text { Resultado da } \\
\text { avaliação }\end{array}$ \\
\hline $\begin{array}{l}\text { Porque o Projeto mandava as pessoas } \\
\text { assim, de qualquer forma, vinha muitos } \\
\text { estudantes (para desenvolver atividades } \\
\text { nos serviços). Tava invadindo o serviço } \\
\text { (...). Marcava reunião na hora em que } \\
\text { queria marcar lá. A gente não era chamado } \\
\text { pra participar e pra decidir junto ao Projeto } \\
\text { UNI. Então o que acontecia era uma } \\
\text { questão muito autoritária do Projeto. }\end{array}$ & \begin{tabular}{|l|} 
Participação dos \\
serviços de saúde \\
nas decisões
\end{tabular} & Estava & $\begin{array}{l}\text { Invadindo o } \\
\text { serviço } \\
\text { Muito autoritária }\end{array}$ & $\begin{array}{l}\text { Desempenho } \\
\text { negativo } \\
\text { Qualidade } \\
\text { negativa }\end{array}$ \\
\hline $\begin{array}{l}\text { Inclusive o Projeto UNI, que era uma coisa } \\
\text { que se tinha, excelente pra gente. Porque, } \\
\text { aconteceu de equipar a unidade de muita } \\
\text { coisa, inúmeras coisas, auditório, de } \\
\text { muitas e muitas coisas, e o Projeto UNI } \\
\text { saiu de dentro da unidade e a gente não } \\
\text { sabe, entendeu, por que saiu. }\end{array}$ & \begin{tabular}{|lr} 
Investimento r na \\
infra-estrutura das \\
unidades r de \\
saúde
\end{tabular} & $\begin{array}{l}\text { Era } \\
\text { Equipar }\end{array}$ & $\begin{array}{l}\text { Excelente } \\
\text { Muitas coisas }\end{array}$ & $\begin{array}{l}\text { Qualidade } \\
\text { positiva } \\
\text { (Tempo passado) } \\
\text { Desempenho } \\
\text { positivo }\end{array}$ \\
\hline
\end{tabular}

Balanço: as qualidades e o desempenho identificados são anulados no balanço final, além de apontarem para aspectos divergentes. Se destaca uma outra vez a avaliação positiva referida ao tempo passado. 
Quadro 28d - Análise avaliativa do "espaço de parceria" no Projeto UNI/BA por ex-membro da Coordenação do DSBRV, 1999

\begin{tabular}{|c|c|c|c|c|}
\hline Como é descrita & $\begin{array}{c}\begin{array}{c}\text { Objeto de } \\
\text { atitude }\end{array} \\
\end{array}$ & $\begin{array}{c}\text { Conector } \\
\text { verbal }\end{array}$ & $\begin{array}{c}\text { Termo } \\
\text { avaliativo }\end{array}$ & $\begin{array}{c}\text { Resultado da } \\
\text { avaliação }\end{array}$ \\
\hline $\begin{array}{l}\text { Como sempre eu acho que o Projeto UNI só veio a } \\
\text { somar com o distrito. Eu não vejo ponto negativo no } \\
\text { Projeto UNI em nada. Para o distrito não. Porque } \\
\text { sem o Projeto UNI a gente não tinha ido pra lugar } \\
\text { nenhum. }\end{array}$ & $\begin{array}{l}\text { Influência na } \\
\text { gestão do } \\
\text { DSBRV }\end{array}$ & $\begin{array}{l}\text { Veio } \\
\text { (não) Tinha }\end{array}$ & $\begin{array}{l}\text { Somar } \\
\text { Ido pra lugar } \\
\text { nenhum (sem } \\
\text { o Projeto) }\end{array}$ & $\begin{array}{l}\text { Qualidade } \\
\text { positiva } \\
\text { Desempenho } \\
\text { positivo }\end{array}$ \\
\hline $\begin{array}{l}\text { Eu acho que outro ponto que eu logo no inicio } \\
\text { observei, que a gerência do distrito era o Projeto } \\
\text { UNI. Isso era muito forte. (...) como também o } \\
\text { espaço físico de decisão não era o espaço físico da } \\
\text { geréncia do distrito. Era o espaço físico do UNI. } \\
\text { Espaço físico e espaço político era do Projeto UNI. }\end{array}$ & & $\begin{array}{l}\text { Era } \\
\text { Era }\end{array}$ & $\begin{array}{l}\text { Muito forte } \\
\text { Espaço de } \\
\text { decisão (o } \\
\text { espaço do } \\
\text { Projeto UNI) }\end{array}$ & $\begin{array}{l}\text { Qualidade } \\
\text { negativa } \\
\text { Desempenho } \\
\text { negativo }\end{array}$ \\
\hline
\end{tabular}

Balanço: no balanço final a avaliação é anulada pela contraposiçăo apresentada sobre o mesmo objeto de atitude de qualidade negativa e positiva e desempenho negativo e positivo. 


\subsubsection{Comentários finais}

Num balanço final, o espaço de parceria no Projeto UNI/BA consegue uma avaliação positiva (sete avaliações de desempenho positivas contra seis negativas e seis avaliações positivas de qualidade contra três negativas), com maior ênfase aos aspectos relacionados com qualidade.

Dentre alguns indices analisados, indices esses compreendidos aqui como sinais involuntários, podemos deduzir que há uma clara personificação do Projeto UNI/BA nos participantes vinculados à Universidade, com exceção dos Conselheiros Locais de Saúde representantes da comunidade, únicos parceiros que se auto-identificam como Projeto UNI também.

Dada a constatação dos problemas, no espaço de parceria, com o parceiro serviços de saúde, não é inesperado que trabalhadores da saúde expressem enunciaçōes avaliativas contraditórias - às vezes de reconhecimento, às vezes de agressividade - em relação ao Projeto UNI/BA.

Esta avaliação deve também ser tomada em conta considerando o contexto politico do DSBRV analisado inicialmente, em que se identifica claramente que há contradição entre a proposta de parceria desenvolvida no âmbito do Projeto UNI/BA e a condução politico-administrativa da Secretaria Municipal de Saúde refletida no território do DSBRV. 


\subsubsection{Inovação: o trabalho sobre a violência no Distrito Sanitário Barra/Rio Vermelho}

\subsubsection{Premissas}

Após anos como espectadores e vítimas da violência a população, através das organizações comunitárias, adere ao trabalho pela não-violência em bairros do Distrito Sanitário Barra/Rio Vermelho, em Salvador. Ainda que a violência fosse um problema vivenciado em vários bairros, nunca tinha sido assumida como um foco de intervenções por parte das organizações comunitárias locais e por outras instituições e organizações, públicas ou não, atuando na área. Tradicionalmente considerada e tratada como um problema de polícia, a violência surge, no DSBRV, como um problema de saúde pública a partir da estratégia adotada pelo Projeto UNI/BA de trabalhar por problemas identificados e priorizados coletivamente ${ }^{15}$.

$\mathrm{Na}$ organização do trabalho em parceria através da identificação e planejamento de ações e atividades sobre problemas, a violência é priorizada por ser um tema sobre o qual todos têm algum conhecimento e que agrega diversos atores e interesses.

Esse diferencial na concepção e enfrentamento do problema é considerado como inovador pelos conselheiros locais de saúde, gerentes e trabalhadores da saúde. A partir de 1996, com a organização do Fórum Comunitário de Combate à Violência/FCCV, uma das intervenções apoiadas

\footnotetext{
${ }^{15}$ A estratégia de planejar intervenções conjuntas no território do DSBRV com base em problemas identificados e selecionados coletivamente foi assumida no bojo do Projeto UNI/BA desde o seu início, em 1996. Tal estratégia é compreendida como facilitadora da intervenção sobre a gestão da saúde nesse território de modo a contemplar as necessidades de saúde da população e ampliar o conceito de saúde e a intervenção sobre situações que tradicionalmente não fazem parte das atribuições do setor saúde. A intervenção sobre problemas obriga necessariamente a algum grau de trabalho em parceria com outras organizações e instituições para o alcance de resultados.
} 
pelo Projeto UNI/BA, coordenado pela Universidade Federal da Bahia, começa um trabalho focado na violência e com essa nova caracteristica.

O $\mathrm{FCCV}^{16}$, definido como uma inovação gerencial ainda não consolidada, é constituído por entidades governamentais e nãogovernamentais com atuação na área do Distrito Sanitário Barra/Riu Vermelho "com o propósito de desenvolver açōes intersetoriais e articuladas de promoção da saúde, prevenção dos agravos, recuperação e reabilitação das vitimas das violências, problemas prioritários em função de sua magnitude e transcendência. A necessidade de somar esforços de diversos setores para o enfrentamento da violência decorre da própria complexidade do problema" (FORUM COMUNITÁRIO DE COMBATE À VIOLÉNCIA 1999, p. 3).

\footnotetext{
${ }^{16}$ O FCCV em agosto de 2000 estava composto por: Associação dos Moradores e Amigos do Garcia, Associação de Moradores do Nordeste de Amaralina, Associação Bahiana de Medicina/ABM, Associação Cultural Beneficente e Esportiva São Salvador, Centro de Defesa da Criança e do Adolescente Yves de Roussan/CEDECA, Centro Espirita Caminho da Redenção, Centro Projeto Axé, CIPÓ/Comunicação Interativa, Comunidade do AREAL, Comissão de Justiça e Paz da Arquidiocese do Salvador, Comissão de Violència da Câmara dos Vereadores, Comitè das Entidades no Combate à Fome e Pela Vida, Comunidade da Santa Cruz, Conselho Municipal da Mulher, Conselho Municipal dos Direitos da Criança e do Adolescente, Coordenação de Gestão Participativa, Departamento de Ciências Humanas/Campus 1, Curso de Comunicação Social/UNEB, Centro de Referência do Adolescente Isabel Souto/CRADIS, Centro de Referência Integral do Adolescente/CRIA, Defensoria Pública do Estado, DIRCON/DETRAN, Engenho Novo Publicidade e Promoções, Escola de Belas Artes/UFBA, Escola de Dança/UFBA, Escola Politécnica/UFBA, Federação Espirita da Bahia, Fundação Cidade Mãe/GEPEC, Grupo de Mulheres do Alto das Pombas, Grupo Gay da Bahia, Instituto Médico Legal Nina Rodrigues, Instituto Roerich da Paz e Cultura do Brasil, Instituto de Saúde Coletiva/UFBA, Liceu de Artes e Oficios da Bahia, Ministério Público/Coondenação da Infância e Juventude, Organização do Auxilio Fratemo/OAF, Pastoral da Criança, Pastoral Operária, Policia Militar do Estado da Bahia, Programa UFBA Cidadania e Aprendizagem para o Trabalho, Projeto Educarte, S.O.S. Criança/FUNDAC/SETRAS, SAJU/Faculdade de Direito/UFBA, Sociedade Beneficente de Defesa e Recreativa dos Moradores do Engenho Velho da Federação e Adjacèncias, Sociedade Beneficente e Recreativa do Calabar/SBRC, Serviço de Apoio à Micro e Pequena Empresa/SEBRAE/BA, Secretaria de Segurança Pública (Delegacia de Proteçāo à Mulher, DEMAI, DERCA, Departamento de Policia Técnica), Rede UNIDA, Secretaria Estadual de Educação e Cultura, Secretaria Municipal de Educação, Secretaria Municipal de Saúde, Secretaria de Saúde do Estado da Bahia, Serviço Nacional de Aprendizado Comercial/SENAC, SINDIVIGILANTES/BA, União de Negros pela Igualdade/UNEGRO, UNESCO, UNICEF, UNI-PAZ.
} 
As atividades desenvolvidas pelo FCCV estão articuladas em quatro linhas de açāo:

- Sistema de vigilância da violência

- Assistência as vítimas da violência

- Educação e cidadania

- Mobilização social

\subsubsection{Características}

Sendo um espaço de articulação de interesses e iniciativas em parceria, - FCCV tem sido compreendido de modo distinto pelos atores locais. Um deles é que o trabalho sobre a violência em um espaço com tais características permite mudar o foco do problema violência para além do ambiente policial. Outra caracteristica é facilitar uma articulação interinstitucional e permitir a democratização das informações sobre o problema em toda a cidade.

Identificado como uma intervenção inovadora na gestão da saüde no DSBRV pelos conselheiros locais de saúde e por gerentes das unidades de saúde, o trabalho sobre a violência tem como caracteristica a sua concepção como um problema de saúde pública, e como conseqüência permitir uma intervenção ampliada dos problemas identificados pelas comunidades locais.

As características destacadas sobre a concepção da violência pelos atores locais a identificam como um problema de saúde pública e isto faz com que este problema possa ser concebido de modo mais amplo do que meramente uma questão policial, como descrito a seguir:

E a coisa que a gente viu lá, assim, que me impressionou muito logo foi de outras, de outros segmentos, de outras pessoas e principalmente 
profissionais da área da saúde estarem preocupados com a questão da violência como um problema de saúde pública. $\dot{E}$, é a primeira vez, a primeira vez que a gente viu o tema ser abordado com essa perspectiva. (Entrevista com membro do FCCV)

(...) a saúde abraçou esta questão, né? chamou a violência como um problema de saúde, uma questão de saúde e tá sendo tratada como tal. E é essa conscientização de que a violência é..., acabar com a violência faz parte, né? de você ter uma boa saúde também. (Grupo focal com Conselheiros Locais de Saúde/representantes da comunidade)

O trabalho sobre o problema violência, priorizado pelos grupos da comunidade atuantes no DSBRV, possibilitou relacionar a violência com condições de vida da população e exigir uma intervenção articulada de vários setores e instituições/organizações, intervindo, assim, na gestão local da saúde, o que é ilustrado pelos enunciados:

A gente vê que a violência, vocês dizem, "ha! a violência é porque o desemprego, muitos pais tão desempregados...." Então, o que é? é a negação do direito fundamental de uma pessoa humana. Então o que tá gerando a violência é isso aí. Então quer ver, discutir e ter uma visão mais ampla do que é a violência e quais são as causas e as conseqüências. Então não só na área de saúde, mas como um todo, né? (Grupo focal com Conselheiros Locais de Saúde/representantes da comunidade)

Eu acho que essa campanha de combate à violência pra gente do Distrito Barra/Rio Vermelho, ela é uma cartada fatal pra esfera política. Porque dentro dela você pode trabalhar todas as nossas necessidades, em cima desta campanha contra a violência, né? então você pode trabalhar tudo que a comunidade necessita. (Grupo focal com Conselheiros Locais de Saúde/representantes da comunidade) 
No entanto, a participação do setor saúde, através das secretarias e da própria coordenação do DSBRV, é considerada como a menos envolvida nesse processo. Uma das principais iniciativas, nos serviços de saúde, que foi a implementação de um serviço de referência para o atendimento às vítimas da violência numa das unidades de saúde no DSBRV, foi desativada. As principais barreiras para a atuação dos serviços de saúde no enfrentamento do problema violência são:

- Desestruturação de equipes organizadas para atuar sobre o problema, a exemplo do grupo de vigilância epidemiológica;

- Remanejamento dos trabalhadores capacitados para o enfrentamento da violência para outras atividades segundo critério da coordenação do DSBRV;

- Resistência dos trabalhadores em aceitar atividades relacionadas com o problema violência.

As barreiras confirmam o retrocesso enunciado no trabalho sobre a violência nos serviços de saúde, particularmente quanto à atenção às vítimas no território do DSBRV.

\subsubsection{Repercussões}

Mesmo com as dificuldades descritas foi possivel a análise dessa inovação através das suas repercussões, que retratam qualitativamente um amplo espectro de influências e resultados.

Pela densidade com que são enunciadas, muitas dessas repercussões mereceriam uma investigação e análise mais sistematizadas, o que foge ao escopo do trabalho. Algumas das repercussões também estão sofrendo retrocessos por conta da própria conjuntura política no DSBRV e 
recuo quanto à assunção do problema da violência pela coordenação do DSBRV, o que guarda coerência com a análise negativa que a gestão da saúde no DSBRV foi alvo neste estudo.

A diversidade dos autores de tais repercussões também é um dos elementos que demonstram a sua relevância. Sobressaem dois temas-eixo relacionados com o sucesso das iniciativas: o trabalho em parceria, considerado como o mais importante para o enfrentamento do problema violência e a compreensão da violência, como um problema de grande complexidade e de caráter social abrangente.

As repercussões são apresentadas através das categorizaçōes: repercussões no modo de compreender a realidade e de agir; nas pessoas; nos serviços de saúde; e nas instituições. $A$ análise identifica as unidades de texto que descrevem as repercussões, o autor e o tema-eixo de cada uma. 
Quadro 29 - Repercussões no modo de compreender a realidade e de agir

\begin{tabular}{|c|c|c|}
\hline Como é descrita & Tema-eixo & Autor \\
\hline $\begin{array}{l}\text { Então quer ver, discutir e ter uma visão mais } \\
\text { ampla do que é a violência e quais são as } \\
\text { causas e as conseqüências. Então não só na } \\
\text { área de saúde, mas como um todo, né? Eu } \\
\text { acho que a violência traz assim uma } \\
\text { preocupação da gente vê o outro como um } \\
\text { todo, né? Ai nessa sociedade que tá aí, né? } \\
\text { Tirando tudo que a gente tem direito, e a gente } \\
\text { precisa tá atento pra isso. }\end{array}$ & \multirow[b]{2}{*}{$\begin{array}{l}\text { A violência } \\
\text { como questão } \\
\text { social }\end{array}$} & $\begin{array}{l}\text { Conselheiros } \\
\text { Locais de } \\
\text { Saúde } \\
\text { (representantes } \\
\text { da } \\
\text { comunidade) }\end{array}$ \\
\hline $\begin{array}{l}\text { Eu, eu acho que é essa visão da violência, não } \\
\text { com aquele, não sei se é muito uma opinião da } \\
\text { experiência profissional (hesita em expor sua } \\
\text { idéia), é, é um outro foco. Tá entendendo? Eu, } \\
\text { eu tive assim, pelo menos quando eu comecei a } \\
\text { participar (mantém tom hesitante), é de que diz } \\
\text { assim, não, violência, violência é um tema da } \\
\text { policia. Aquela coisa que a gente tinha muito de } \\
\text { achar que só quem pode falar de violência, né, } \\
\text { (ri), seria o delegado de polícia ou o juiz } \\
\text { criminal, ou o advogado criminalista. E não é! } \\
\text { (...) Então lá (refere-se ao Fórum Comunitário } \\
\text { de Combate à Violência) você vê a discussão } \\
\text { em tomo do tema que é um problema social. } \\
\text { Essa abertura que se deu pra análise, } \\
\text { discussão do tema violência, eu acho } \\
\text { fundamental, fundamental, certo? }\end{array}$ & & $\begin{array}{l}\text { Membro } \\
\text { FCCV }\end{array}$ \\
\hline $\begin{array}{l}\text { E eu acho que isso pra gente, não só como } \\
\text { conselheiros, mas como pessoas da } \\
\text { comunidade, que é da associação de } \\
\text { moradores, que já tem uma atuação..., eu por } \\
\text { exemplo, abriu meus horizontes quanto ao } \\
\text { bairro onde eu moro, porque o bairro mais } \\
\text { violento que vocês ouve falar, né? E essa } \\
\text { discussão possibilitou a gente ver valores, no } \\
\text { entanto, que não eram vistos no nosso bairro. }\end{array}$ & $\begin{array}{l}\text { Valorização do } \\
\text { próprio bairro }\end{array}$ & $\begin{array}{l}\text { Conselheiros } \\
\text { Locais de } \\
\text { Saúde } \\
\text { (representantes } \\
\text { dos } \\
\text { trabalhadores } \\
\text { da saúde) }\end{array}$ \\
\hline $\begin{array}{l}\text { Eu vejo assim, trazer esse tema da violência, } \\
\text { né? O Projeto UNI buscou, suscitou, e o } \\
\text { resultado que a gente tá vendo é a questão } \\
\text { assim, que mobilizou, né? Tem quantas linhas } \\
\text { de ação depois da questão do Fórum contra a } \\
\text { violência? E hoje tá se discutindo não só na } \\
\text { área de saúde, mas de educação, entendeu? }\end{array}$ & $\begin{array}{l}\text { Atuação em } \\
\text { parceria }\end{array}$ & $\begin{array}{l}\text { Conselheiros } \\
\text { Locais de } \\
\text { Saúde } \\
\text { (representantes } \\
\text { da } \\
\text { comunidade) }\end{array}$ \\
\hline
\end{tabular}


Quadro 29a - Repercussões nas pessoas

\begin{tabular}{|c|c|c|}
\hline Como é descrita & Tema-eixo & Autor \\
\hline $\begin{array}{l}\text { E discutir a violència também tá me ajudando a } \\
\text { tolerar tantas coisas, tantos hábitos que as } \\
\text { pessoas..., tantas maneiras, tantas atitudes } \\
\text { que as pessoas têm na vida, principalmente lá } \\
\text { no bairro, lá no Areal que foi um lugar que me } \\
\text { marcou tanto, de tanta violência que eu vi, de } \\
\text { tanta coisa, né? ...tantos meninos que eu vi } \\
\text { pequeno, crescerem, já morreram e tudo. }\end{array}$ & $\begin{array}{l}\text { Ampliação da } \\
\text { tolerância nas } \\
\text { relaçōes } \\
\text { interpessoais }\end{array}$ & $\begin{array}{l}\text { Conselheiros } \\
\text { Locais de Saúde } \\
\text { (representantes } \\
\text { da comunidade) }\end{array}$ \\
\hline $\begin{array}{l}\text { Então quer ver, discutir e ter uma visão mais } \\
\text { ampla do que é a violência e quais são as } \\
\text { causas e as conseqüências. Então não só na } \\
\text { área de saúde, mas como um todo, né? Eu } \\
\text { acho que a violência traz assim uma } \\
\text { preocupação da gente ver o outro como um } \\
\text { todo, né? Ai nessa sociedade que tá aí, né? } \\
\text { Tirando tudo que a gente tem direito e a gente } \\
\text { precisa tá atento pra isso. }\end{array}$ & \begin{tabular}{|l|} 
Visão \\
abrangente da \\
realidade
\end{tabular} & \\
\hline $\begin{array}{l}\text { Então é assim, através de determinado tempo } \\
\text { as pessoas consideravam a saúde e a } \\
\text { população também considerava saúde } \\
\text { enquanto a questão apenas de você tá indo ao } \\
\text { médico porque você está doente. E hoje não, } \\
\text { hoje as pessoas têm uma compreensão } \\
\text { diferente: se a gente pergunta às pessoas o } \\
\text { que é a saúde hoje, as pessoas consideram } \\
\text { saúde... antigamente não era a violência, mas } \\
\text { hoje as pessoas já começam a colocar a } \\
\text { violência como uma questão de saúde. Como } \\
\text { surgiu lá no Nordeste de considerar o estresse } \\
\text { de tá esperando um ônibus como uma questão } \\
\text { de saúde (...). }\end{array}$ & $\begin{array}{l}\text { Ampliação do } \\
\text { conceito de } \\
\text { saúde }\end{array}$ & $\begin{array}{l}\text { Conselheiros } \\
\text { Locais de Saúde } \\
\text { (representantes } \\
\text { da comunidade) }\end{array}$ \\
\hline $\begin{array}{l}\text { Então tudo isso é uma questão de } \\
\text { compreender melhor o outro. Eu acho que } \\
\text { essa coisa assim, de participar da discussão } \\
\text { da violência, é uma coisa que parece que tá lá, } \\
\text { não tá em mim. Mas na verdade tá muito na } \\
\text { gente, não é? Que nos muda. Ainda tem isso. }\end{array}$ & $\begin{array}{l}\text { Aceitação das } \\
\text { diferenças }\end{array}$ & $\begin{array}{l}\text { Conselheiros } \\
\text { Locais de Saúde } \\
\text { (representantes } \\
\text { da comunidade) }\end{array}$ \\
\hline
\end{tabular}

Dentre as categorias de repercussões identificadas, a repercussão sobre as pessoas aparece como uma das mais relevantes. Essa relevância é destacada pelas enunciações dos Conselheiros Locais de Saúde representantes da comunidade, através dos diferentes temas-eixo 
destacados, bem como pela ocorrência de tais enunciações em diversos momentos dos grupos focais. A intensidade é também retratada pelos depoimentos no tempo presente (observada no tempo verbal das enunciaçōes destacadas no quadro).

Quadro 29b - Repercussões nos serviços de saúde

\begin{tabular}{|c|c|c|}
\hline Como é descrita & Tema-eixo & Autor \\
\hline $\begin{array}{l}\text { Mas se conseguiu uma sensibilização } \\
\text { grande por parte dos profissionais, pra lidar } \\
\text { como profissionais. (...) e eu posso dizer } \\
\text { que os profissionais aqui, eles já } \\
\text { conseguem ter um olhar diferenciado nesse } \\
\text { sentido. (...). Mas é, foi um trabalho de } \\
\text { sensibilização importante. }\end{array}$ & \multirow[t]{2}{*}{$\begin{array}{l}\text { Sensibilização } \\
\text { dos } \\
\text { trabalhadores da } \\
\text { saúde para o } \\
\text { problema }\end{array}$} & $\begin{array}{l}\text { Gerente } \\
\text { Unidade } \\
\text { Saúde }\end{array}$ \\
\hline $\begin{array}{l}\text { O problema da violência mesmo começou } \\
\text { ai, numa discussão dessa, né? E que } \\
\text { mexeu muito com o serviço, o serviço ai } \\
\text { tremeu nas pernas, né? Mas começou, } \\
\text { começou. }\end{array}$ & & $\begin{array}{ll}\text { Ex-membro } & \text { da } \\
\text { Coordenação } & \text { do } \\
\text { DSBRV } & \end{array}$ \\
\hline $\begin{array}{l}\text { Eu não sei se é diferente mas o Distrito } \\
\text { Barra ele tem mais dados, essa questão da } \\
\text { violência, tem a pesquisa da Universidade, } \\
\text { os resultados desses encontros que houve } \\
\text { nas unidades de ensino, saúde. Acho que } \\
\text { isso faz uma diferença sim. Por exemplo, } \\
\text { essas caminhadas (refere-se às } \\
\text { manifestações públicas da campanha } \\
\text { comunitária "Declare amor ao seu bairro"), } \\
\text { isso é uma resultante de um trabalho que } \\
\text { vem acontecendo e eu não vejo falar isso } \\
\text { em outros bairros. }\end{array}$ & $\begin{array}{l}\text { Disponibilidade } \\
\text { de informações } \\
\text { e atuação sobre } \\
\text { o problema }\end{array}$ & $\begin{array}{l}\text { Conselheiros } \\
\text { Locais de Saúde } \\
\text { (representantes } \\
\text { dos } \\
\text { trabalhadores da } \\
\text { saúde) }\end{array}$ \\
\hline $\begin{array}{l}\text { A outra coisa inovadora é o trabalho } \\
\text { intersetorial na violência. Taí uma outra } \\
\text { coisa inovadora que eu, que nós } \\
\text { provocamos, nós eu digo a articulação UNI, } \\
\text { a percepção das unidades como rede, que } \\
\text { elas não tinham nenhuma. }\end{array}$ & $\begin{array}{l}\text { Percepção dos } \\
\text { serviços de } \\
\text { saúde enquanto } \\
\text { rede }\end{array}$ & $\begin{array}{l}\text { Membro da } \\
\text { Coordenação } \\
\text { Executiva do } \\
\text { Projeto UNI/BA }\end{array}$ \\
\hline $\begin{array}{l}\text { Mas o fato de que aconteceu, como eu já } \\
\text { falei antes, foi na gincana, eles (refere-se ao } \\
\text { serviço de saúde no bairro) ficaram à frente } \\
\text { da gincana do "Declare amor ao seu bairro". } \\
\text { A gincana toda foi falando sobre DST/AIDS, } \\
\text { violència. }\end{array}$ & $\begin{array}{l}\text { Participação da } \\
\text { unidade local de } \\
\text { saúde }\end{array}$ & Usuários \\
\hline
\end{tabular}


As enunciações relacionadas com as repercussões nos serviços são as mais frágeis, reforçando que nesse campo estas sofreram com o retrocesso da própria posição do distrito quanto ao trabalho sobre a violência.

Os temas-eixo indicam apenas mudanças na sensibilização/percepção do problema que não se traduz em mudanças nas atitudes ou ações desenvolvidas pelos trabalhadores da saúde. Isso é reforçado pelo fato de não aparecer o tema nos grupos e entrevistas realizados com esses trabalhadores. 
Quadro 29c - Repercussões nas instituições

\begin{tabular}{|c|c|c|}
\hline Como é descrita & Tema-eixo & Autor \\
\hline $\begin{array}{l}\text { Então eu acho assim que o grupo, a coisa da } \\
\text { violência, de ter instituido um pouco uma } \\
\text { prática, uma forma de conduzir a saúde } \\
\text { interinstitucionalmente, eu acho que isso foi } \\
\text { feito, que ainda não está institucionalizado, } \\
\text { mas assim, as instituiçōes diversas estão se } \\
\text { articulando (...). }\end{array}$ & $\begin{array}{l}\text { Articulação } \\
\text { interinstitucional }\end{array}$ & $\begin{array}{l}\text { Membro da } \\
\text { Coordenação } \\
\text { Executiva do } \\
\text { Projeto UNI/BA }\end{array}$ \\
\hline $\begin{array}{l}\text { Não só você agregou gente para fazer } \\
\text { conjuntamente, como influenciou mesmo no } \\
\text { interior das próprias instituições. Você tem } \\
\text { hoje a segurança pública, que embora você } \\
\text { não vê, você vê só no discurso que prioridade } \\
\text { é a violência, não tenha visto antes um } \\
\text { traçado de politica, mas as coisas estão } \\
\text { acontecendo. As modificações que estão } \\
\text { acontecendo na delegacia de proteção à } \\
\text { mulher, de proteção à criança. (...). Eu diria } \\
\text { que muita coisa mudou na gestão dessas } \\
\text { instituiçōes, que agora elas começam a } \\
\text { perceber o que é importante para rastrear, pra } \\
\text { saber onde e quando está acontecendo e a } \\
\text { partir desse acontecimento precisa fazer } \\
\text { alguma ação. }\end{array}$ & $\begin{array}{l}\text { Organização do } \\
\text { trabalho }\end{array}$ & \\
\hline $\begin{array}{l}\text { Nós temos vinte e quatro anos de atividade } \\
\text { policial, então você tem que ter pelo menos } \\
\text { essa visão de que agora pelo menos se senta } \\
\text { com outros parceiros, certo? A coisa não fica } \\
\text { só do ponto de vista da instituição. Tanto a } \\
\text { segurança como outras está buscando, né, } \\
\text { outras formas de atuação, como outras } \\
\text { entidades estão vindo sentar com a gente, } \\
\text { discutir com a gente formas de minimizar isso. }\end{array}$ & $\begin{array}{l}\text { Trabalho } \\
\text { parceria }\end{array}$ & $\begin{array}{l}\text { Membro } \\
\text { FCCV }\end{array}$ \\
\hline
\end{tabular}

O significado maior nas repercussões identificadas em outras instituições está relacionado com uma adoção de visão mais ampla do problema da violência e reconhecimento do trabalho articulado. No entanto, ressente-se de uma ação mais efetiva cuja repercussão seja externa a cada instituição em particular. Tais dificuldades podem ficar mais claras quando se apresenta a análise de avaliação tendo como objeto a atuação do FCCV que reflete a atuação articulada entre as instituições engajadas no trabalho contra a violência no DSBRV. 


\subsubsection{Avaliação do trabalho sobre a violência}

Seguindo o mesmo percurso anterior das análises de avaliação já realizadas, apresentamos os quadros com os resultados avaliativos do trabalho sobre a violência no DSBRV.

No balanço final das análises confirma-se um desempenho positivo para o FCCV apesar das claras referências aos seus limites, principalmente por uma atuação pouco eficaz dos seus membros.

A mesma homogeneidade é observada quando o objeto de atitude da avaliação é a atuação dos serviços de saúde, agora para o resultado final de um desempenho negativo e uma referência positiva ao desempenho no passado. Tal resultado é coerente com a avaliação da atuação da própria Coordenação do DSBRV, cujo desempenho é considerado negativo pelos trabalhadores da saúde.

No único registro do trabalho sobre a violência pelos usuários esta é também avaliado negativamente quanto ao desempenho. De fato, 0 acesso a informações sobre o próprio trabalho e sobre o problema da violência nos bairros é muito insuficiente para a população local, como pude observar durante o trabalho de campo. De tal fato posso inferir que a população local, com exceção das lideranças e conselheiros de saúde diretamente envolvidos no trabalho, ainda desconhece as iniciativas e a própria existência do FCCV e outras estratégias utilizadas no trabalho sobre a violência. 
Quadro 30 - Análise avaliativa do trabalho sobre a violencia por Conselheiros Locais de Saúde representantes da comunidade, DSBRV, 1999

\begin{tabular}{|c|c|c|c|c|}
\hline Como é descrita & $\begin{array}{c}\text { Objeto de } \\
\text { atitude }\end{array}$ & $\begin{array}{l}\text { Conector } \\
\text { verbal }\end{array}$ & $\begin{array}{c}\text { Termo } \\
\text { avaliativo }\end{array}$ & $\begin{array}{l}\text { Resultado da } \\
\text { avaliação }\end{array}$ \\
\hline $\begin{array}{l}\text { Eu acho que essa campanha de combate à violència, } \\
\text { ela deve durar, não deve ter um prazo para acabar, } \\
\text { entendeu? ela deve ser repensada. Com pessoas que } \\
\text { conheçam coisas, argumentos técnicos, entendeu, que } \\
\text { ela seja repensada. Essa campanha de combate à } \\
\text { violéncia realmente é inovadora, né? }\end{array}$ & $\begin{array}{l}\text { Estratégia } \\
\text { de } \\
\text { campanhas }\end{array}$ & Deve & $\begin{array}{l}\text { Não ter prazo } \\
\text { para acabar } \\
\text { Ser repensada }\end{array}$ & $\begin{array}{l}\text { Qualidade positiva } \\
\text { Desempenho } \\
\text { positivo }\end{array}$ \\
\hline $\begin{array}{l}\text { Que a gente discutia muito muito a questão da } \\
\text { violência, que se brigava muito, a gente discutia } \\
\text { principalmente a violência policial. Depois foi se } \\
\text { trazendo pra outros campos, a violência familiar, a } \\
\text { violência na mulher, todo tipo... Então... foi a partir do } \\
\text { Projeto (refere-se ao Projeto UNI/BA), do Fórum, que } \\
\text { se ampliou, que tá mudando a cara, né? Tanto que, por } \\
\text { exemplo, a gente tá na sociedade discutindo a questão } \\
\text { da violéncia nas escolas, tal e tal, mas não se vê o } \\
\text { porquê dessa violência. Se discute muito já as } \\
\text { conseqüências, mas as causas não se discute. }\end{array}$ & $\begin{array}{l}\text { Atuação do } \\
\text { FCCV }\end{array}$ & $\begin{array}{l}\text { Foi } \\
\text { Ampliou (a } \\
\text { partir do } \\
\text { Projeto) }\end{array}$ & $\begin{array}{l}\text { Mudando a } \\
\text { cara } \\
\text { Discute causas } \\
\text { e } \\
\text { conseqüências }\end{array}$ & $\begin{array}{l}\text { Qualidade positiva } \\
\text { Desempenho } \\
\text { positivo }\end{array}$ \\
\hline
\end{tabular}

Balanço: tanto em desempenho quanto em qualidade a avaliação dos conselheiros locais de saúde sobre a atuação do Projeto UNI/BA frente ao problema violência é positiva. Esse valor positivo guarda relação com a maior participação e repercussão desse trabalho sobre os conselheiros. 
Quadro 30a - Análise avaliativa do trabalho sobre a violéncia por membro do Fórum Comunitário de Combate à Violência, DSBRV, 1999

\begin{tabular}{|c|c|c|c|c|}
\hline Como é descrita & $\begin{array}{c}\text { Objeto de } \\
\text { atitude }\end{array}$ & $\begin{array}{l}\text { Conector } \\
\text { verbal }\end{array}$ & $\begin{array}{c}\text { Termo } \\
\text { avaliativo }\end{array}$ & Resultado da avaliação \\
\hline $\begin{array}{l}\text { Então a importância fundamental do Fórum, pelo menos na minha visão, é } \\
\text { essa discussão. (...) E a partir do momento que você discute, que abre o } \\
\text { horizonte, você dá a possibilidade das outras pessoas apresentarem a } \\
\text { proposta, certo? Que fica dificil para o cidadão comum, né, ter até acesso } \\
\text { à autoridade e dizer: "faça dessa forma". Mas quando você tem uma } \\
\text { entidade, né, um gnupo da sociedade organizada, você tem mais condição } \\
\text { de ser ouvida, né, e de fazer ouvir essas pessoas. Entendeu? }\end{array}$ & Papel do FCCV & $\begin{array}{l}\text { Ampliar } \\
\text { Trazer } \\
\text { Dar }\end{array}$ & $\begin{array}{l}\text { Insumos } \\
\text { importantes } \\
\text { Possibilidade } \\
\text { Acesso } \\
\text { Condição }\end{array}$ & $\begin{array}{l}\text { Qualidade positiva } \\
\text { Desempenho positivo }\end{array}$ \\
\hline $\begin{array}{l}\text { E a gente pode fazer, acho que o Fórum abre essa perspectiva, da gente } \\
\text { fazer um trabalho realmente de rede, daquela coisa integrada, de } \\
\text { delegacia, de posto médico, de tá com o profissional de saúde, de tá com o } \\
\text { profissional de polícia e de que forma a gente pode fazer. Então, o trabalho } \\
\text { do Fórum, nesse sentido, é de fundamental importância. }\end{array}$ & $\begin{array}{l}\text { Concepção do } \\
\text { FCCV }\end{array}$ & $\begin{array}{l}\text { Abre } \\
\text { Fazer }\end{array}$ & $\begin{array}{l}\text { Trabalho de } \\
\text { rede } \\
\text { Trabalho } \\
\text { integrado }\end{array}$ & Qualidade positiva \\
\hline $\begin{array}{l}\text { E o que eu acho que a gente poderia avançar mals, seria no aspecto da } \\
\text { intervenção. Porque já que o Fórum abre esse pólo de discussão e de } \\
\text { trabalho conjunto, nós deveríamos estar, pelo tempo que o Fórum já se } \\
\text { reúne, pela experiência que já tem, pelo estudo concreto que já tem, da } \\
\text { gente bolar um trabalho, um trabalho assim, do ponto de vista até de ser } \\
\text { implementado como política mesmo do governo, né? O que é que a gente } \\
\text { vai fazer nessa área especifica? Isso. E aí os profissionais atuariam nessa } \\
\text { área. }\end{array}$ & $\begin{array}{l}\text { Atuação do } \\
\text { FCCV }\end{array}$ & $\begin{array}{l}\text { Deveriamos } \\
\text { estar }\end{array}$ & $\begin{array}{l}\text { Implementando } \\
\text { o trabalho como } \\
\text { politica }\end{array}$ & Desempenho negativo \\
\hline $\begin{array}{l}\text { Então eu acho que o caminho é o Fórum, certo? Que as entidades têm que } \\
\text { ver o Fórum como realmente esse pólo de discussão, de propostas, de } \\
\text { encaminhamento. Porque ele já é uma realidade. Eu acho, entendeu, que } \\
\text { algumas entidades ainda estão muito tímidas em relação a isso. }\end{array}$ & $\begin{array}{l}\text { Atitude dos } \\
\text { membros do } \\
\text { FCCV }\end{array}$ & Estão & Muito tímidas & Desempenho negativo \\
\hline
\end{tabular}

Balanço: a avaliação está focada no FCCV apontando qualidades positivas e desempenho negativo do Fórum, cujo parâmetro é o seu tempo de existência. O desempenho negativo é reforçado na avaliação do desempenho da maioria dos membros do FCCV e pela falta de uma atuação mais efetiva. 
Quadro 30b - Análise avaliativa do trabalho sobre a violência por Membros da Coordenação Executiva do Projeto UNI/BA, DSBRV, 1999

\begin{tabular}{|c|c|c|c|c|}
\hline Como é descrita & Objeto de atitude & $\begin{array}{l}\text { Conector } \\
\text { verbal }\end{array}$ & Termo avaliativo & Resultado da avaliação \\
\hline $\begin{array}{l}\text { (...) e dentro desse movimento o que era } \\
\text { mais visivel era a violência, tinha um } \\
\text { aspecto que era conduzido, se eu pudesse } \\
\text { dizer assim, pela gestão do sistema, pelo } \\
\text { serviço, que era assumido pelo sistema e } \\
\text { pela gestão do sistema, que era a } \\
\text { assistência à vítima (da violéncia), e deixou } \\
\text { de existir, desapareceu no ar. Como se não } \\
\text { existisse mais, como se a vitima não } \\
\text { existisse mais. }\end{array}$ & $\begin{array}{l}\text { Assistência à vítima } \\
\text { da violência pelos } \\
\text { serviços de saúde }\end{array}$ & $\begin{array}{l}\text { Era } \\
\text { Conduzido } \\
\text { Deixou } \\
\text { Existir }\end{array}$ & $\begin{array}{l}\text { Assumido pelo sistema } \\
\text { Desapareceu no ar }\end{array}$ & $\begin{array}{l}\text { Desempenho positivo } \\
\text { (tempo passado) } \\
\begin{array}{l}\text { Desempenho negativo (tempo } \\
\text { presente) }\end{array}\end{array}$ \\
\hline $\begin{array}{l}\text { Oito dos doze batalhões da polícia estāo } \\
\text { aqui, eles estão trabalhando com o } \\
\text { Conselho de Segurança, com o Conselho } \\
\text { Local de Saúde, quer dizer, o Forum está } \\
\text { gerindo a saúde. Porque na medida em que } \\
\text { se faz uma discussão, define e eles (a } \\
\text { policia) atendem assim imediatamente, } \\
\text { então é um gestor (...). E com certeza não é } \\
\text { por conta da Secretaria da Saúde, nada, foi } \\
\text { o Fórum mesmo quem fez esse trabalho. }\end{array}$ & Atuação do FCCV & $\begin{array}{l}\text { Está } \\
\text { Fez }\end{array}$ & $\begin{array}{l}\text { Gerindo a saúde } \\
\text { Esse trabalho }\end{array}$ & Desempenho positivo \\
\hline
\end{tabular}

Balanço: mais uma vez a avaliação se defronta com um desempenho positivo dos serviços de saúde no tempo passado e negativo no tempo presente. Quando o objeto de atitude é a atuação do FCCV, este recebe uma avaliação positiva quanto ao desempenho. 
Quadro 30c - Análise avaliativa do trabalho sobre a violência por Usuários dos Serviços de Saúde, DSBRV, 1999

\begin{tabular}{|c|c|c|c|c|}
\hline Como é descrita & $\begin{array}{c}\text { Objeto de } \\
\text { atitude }\end{array}$ & Conector verbal & Termo avaliativo & $\begin{array}{l}\text { Resultado da } \\
\text { avaliação }\end{array}$ \\
\hline $\begin{array}{l}\text { Você falar de um conselho de saúde, um Fórum de } \\
\text { Combate à Violência, que eu mesmo vim saber desse } \\
\text { Fórum, que existe dentro do bairro, há pouco tempo. } \\
\text { Que eu não sabia, há pouco tempo eu vim participar } \\
\text { de uma reunião e tal. Pouquíssimo tempo. }\end{array}$ & $\begin{array}{l}\text { Acesso à } \\
\text { informação sobre } \\
\text { o FCCV }\end{array}$ & Vim saber & Pouco tempo & $\begin{array}{l}\text { Desempenho } \\
\text { negativo }\end{array}$ \\
\hline
\end{tabular}

Balanço: o desempenho negativo quanto ao acesso a informações sobre o FCCV pelos usuários aponta uma das fragilidades desta inovação. Esta é praticamente desconhecida pelos usuários. 
Quadro 30d - Análise avaliativa do trabalho sobre a violéncia por Gerente de Unidade de Saúde, DSBRV, 1999

\begin{tabular}{|c|c|c|c|c|}
\hline Como é descrita & Objeto de atitude & Conector verbal & Termo avaliativo & $\begin{array}{c}\text { Resultado da } \\
\text { avaliação }\end{array}$ \\
\hline $\begin{array}{l}\text { Assim como também a violência. Que } \\
\text { foi uma questão identificada aqui na } \\
\text { comunidade e que existe, não existe } \\
\text { um trabalho efetivo de intervenção. } \\
\text { (...). Não é algo que chega a ter uma } \\
\text { repercussão epidemiológica, digamos } \\
\text { assim. Diminuiu a violência na área. } \\
\text { Não, não. Mas é, foi um trabalho de } \\
\text { sensibilização importante. }\end{array}$ & $\begin{array}{l}\text { Atuação dos serviços } \\
\text { de saúde }\end{array}$ & $\begin{array}{l}\text { (Năo) Existe } \\
\text { (Não) Ter } \\
\text { E } \\
\text { Foi }\end{array}$ & $\begin{array}{l}\text { Trabalho efetivo } \\
\text { Repercussão } \\
\text { epidemiologica } \\
\text { Trabalho de } \\
\text { sensibilização } \\
\text { importante }\end{array}$ & $\begin{array}{l}\text { Desempenho negativo } \\
\text { Qualidade positiva }\end{array}$ \\
\hline
\end{tabular}

Balanço: a avaliação aponta qualidade positiva na intervenção dos serviços sobre o problema mas com desempenho negativo. Disso pode ser inferido que a maior atuação foi no passado e não existia mais quando da coleta da informação. 
Quadro 30e - Análise avaliativa do trabalho sobre a violência por Trabalhadores da Saúde, DSBRV, 1999

\begin{tabular}{|c|c|c|c|c|}
\hline Como é descrita & Objeto de atitude & Conector verbal & Termo avaliativo & $\begin{array}{l}\text { Resultado da } \\
\text { avaliação }\end{array}$ \\
\hline $\begin{array}{l}\text { E a discussão sobre a } \\
\text { violência no distrito é uma } \\
\text { coisa que eu acho } \\
\text { fundamental e importante. } \\
\text { Mas que a gente não vê., } \\
\text { vamos dizer... só tinha uma } \\
\text { pessoa que era responsável } \\
\text { por isso, com uma } \\
\text { interlocução com a } \\
\text { Universidade e com o } \\
\text { Projeto UNI. Mas a própria } \\
\text { gerência do distrito, ela não } \\
\text { assume isso como um } \\
\text { projeto, como uma coisa } \\
\text { importante dela. }\end{array}$ & $\begin{array}{l}\text { Atuação ou postura } \\
\text { da Coordenação do } \\
\text { DSBRV }\end{array}$ & $\begin{array}{l}\text { Tinha } \\
\text { (Não) Assume }\end{array}$ & $\begin{array}{l}\text { Uma pessoa } \\
\text { responsável } \\
\text { Como importante }\end{array}$ & $\begin{array}{l}\text { Desempenho } \\
\text { negativo }\end{array}$ \\
\hline
\end{tabular}

Balanço: a atitude da coordenação do DSBRV no trabalho sobre a violéncia é avaliada negativamente quanto ao seu desempenho. 


\subsubsection{Comentários finais}

Considerada como uma resposta pragmática à desordem (BALANDIER 1997), o trabalho sobre a violência no DSBRV traz entre suas caracteristicas mais relevantes possibilitar a expressão do humano nos parceiros envolvidos com esse movimento. O FCCV, estratégia nuclear desse trabalho, torna-se um espaço de criação continua e incessante de alternativas. Demonstra, na sua composição e atuação, ser um espaço onde as vontades coletivas podem romper a impotência, a baixa auto-estima e a incapacidade no enfrentamento de problema tão complexo.

Uma das qualidades no FCCV é de ser um espaço em que todos se sentem e agem como parte integrante de uma articulação, mesmo com a disparidade de interesses e objetivos especificos dos grupos, instituições e organizações que o compõem.

Com o potencial agregador que possui, o FCCV pode ser um recurso inventivo e capaz de dar respostas adaptadas à realidade local. Como espaço de inspiração, formação e animação dos individuos e instituições que o compõem, pode ser, se cultivar ainda mais a democracia e a busca constante da autonomia e da solidariedade, uma resposta à desordem da violência. 


\section{CONSIDERAÇÕES FINAIS}

O ponto de partida para o desenvolvimento desse estudo de caso foi meu entendimento de que possiveis mudanças na gestão pública brasileira estão diretamente relacionadas com 0 estímulo e valorização de experiências locais, sem que se deva necessariamente esperar por transformações estruturais. Quanto à gestão pública da saúde, esta é um campo de instabilidades que devem ser investigadas para se compreender $e$ melhor agir na sua condução. Concomitantemente, o processo de descentralização na saúde, mesmo considerando seus diferentes argumentos e objetivos, (...) "cria problemas complexos para os quais não há resposta única, e cujas soluçōes estão muito ligadas ao contexto histórico específico, razão pela qual as comparações não funcionam" (KLIKSBERG 1997, p. 64).

A compreensão e a disseminação de práticas inovadoras desenvolvidas em espaços locais, nem sempre apoiadas ou estimuladas por iniciativas da administração central da organização saúde, são fundamentais para colaborar com a consolidação de uma nova gestão pública em saúde, que não corresponde aos modelos estabelecidos pela NPM. Neste sentido, a valorização do que pode ser considerado também como uma "comunidade de práticas"17 e a disseminação das experiências desenvolvidas servem de pontos de referência e uma oportunidade impar de reflexão, confronto e discussão frente às propostas institucionais de reforma da administração pública brasileira.

\footnotetext{
${ }^{17}$ Uma comunidade de práticas è a formação de um grupo de pessoas que desenvolvern atividades e interagem de modo informal, em tomo de interesses comuns e buscando desenvolver elementos básicos que permitam aprender e estimular a cooperação. Ver a este respeito: Tomassini $M$ e Bonaretti $M$. Le comunità di pratica nei processi di innovazione della pubblica amministrazione. In: Battistelli (a cura di). La pubblica amministrazione tra riforma e mutuamento culturale. Milano: Angeli; 2001, e Perleth $M$, Jakubowski $E$ and Busse R. What is best practice in health care? State of the art and perspectives in improving the effectiveness and efficiency of the European health care systems. Health Policy 2001; 56:235-250.
} 
Ousando um pouco mais, posso afirmar que as inovações analisadas são exemplos do que CAMPOS (1994) chama de reordenação de micropoderes. Portanto, a análise aqui descrita busca delinear, o mais nitidamente possivel, um retrato do que os praticantes da gestão em saúde fazem em termos de criação/identificação/utilização de inovações e não o que dizem as bases teóricas que apóiam a construção de modelos de gestão. Isto inclui compreender o conteúdo particular de cada uma das inovações, mas estas não podem ser tomadas como instrumentos ou modelos, dado que são síntese de insights e potências para a criação de novos conhecimentos (PEILE 1994) e, espera-se, novos modos de agir.

Essa opção foi tomada considerando que a gestão em saúde é também uma ação política. E, ainda que não seja o objetivo desta investigação apontar referências para superar tal lacuna, considero que não existe uma base teórica sólida e disseminada para mudar a gestão pública em saúde no Brasil. Assim, analisar inovações na gestão a partir de perspectivas diferentes de atores/gestores e com abordagens que valorizam o não-institucional pode ser uma contribuição, ainda que muito modesta.

Ao lado disso, agrego a crença de que somente a prática radical de tais experimentos é que nos conduzirá à descoberta de caminhos próprios e coerentes com a realidade local. A pergunta fundamental, nesse processo de descoberta, é o que terá a capacidade de irradiar o nosso imaginário. Deste modo, os exemplos de inovações na gestão da saúde aqui descritos e analisados podem servir de inspiração para o "agir público", que exige agregação de energia humana, alguns pontos de consenso e capacidade de direção.

O estudo de caso foi realizado também como um exercício de pensar além da ordem estabelecida, buscando inovações na gestão em saúde em um contexto local aparentemente desfavorável. Analisar as inovaçōes como possibilidades permitiu transpor os limites do senso comum com que estas 
sempre se vinculam. Até porque as mudanças sociais não se dão de modo linear, e as inovações na gestão - tomadas por alguns dos atores locais como possibilidades de alternativas da prática social - podem ser suprimidas elou eliminadas no curso da história (BAUMAN 1977, p. 131).

Entender a inovação na gestão como um acontecimento no cotidiano, isto é, como um processo que nāo pode ser regularizado estatisticamente, possibilitou "a busca de um conhecimento (...), examinável, conclusivo, de fenômenos diferentes daqueles confiadamente explorados pela ciência social positiva: a saber, os fenômenos não-rotinizados, ainda irregulares, fora do comum, observáveis ou simplesmente concebiveis, os quais, em certo sentido, podem ser considerados como um vislumbre do futuro ou de uma realidade alternativa" (BAUMAN 1977, p. 157).

A realização de um estudo de caso desta natureza (método indutivo) pretendeu também contribuir com a disseminação de "outras culturas", criando assim um terreno favorável ao avanço de práticas cada vez mais radicais e que possam nos conduzir também a uma lógica gerencial favorável à operacionalização do SUS, ou melhor, dos vários SUS que devem ser implementados e reimplementados no Brasil.

Dos resultados da investigação quero destacar aqueles que reforçam a relevância de estudar inovações na gestão em saúde na perspectiva aqui assumida:

- A capacidade de atores/gestores locais em transformar projetos e programas institucionais de saúde, com desenhos e implementação estabelecidos verticalmente, em espaços diferenciados de ação, comunicação e relação.

- A capacidade de implementação das inovações num contexto em que o fator liderança está fora do âmbito institucional/organizacional da saúde, 
mas fortemente apoiado por atores que dele fazem parte. Foi observado o quanto este aspecto é relevante para a criação e, se não aceitação por parte da instituição, "convivência" com as inovações.

- O papel relevante dos representantes das camadas ditas mais pobres da sociedade, que demonstram maior envolvimento e mesmo capacidade de identificar e compreender o significado das inovaçōes. Isso confirma o que SANTOS (1996, p. 261) diz, referindo-se a tais grupos da população: diante das redes técnicas e informacionais os pobres e marginalizados são quase sempre passivos. Mas é no campo comunicacional que eles são mais ativos do que as camadas ditas "superiores" da sociedade, demonstrando grande capacidade na busca de novos usos e finalidades para técnicas, normas e práticas. Um exemplo é a concepção de saúde expressada pelos conselheiros locais de saúde, representantes da comunidade, que demonstra a incorporação de conhecimentos teóricos avançados sobre os determinantes do estado da saúde e do processo saúde/doença. Ou a identificação e expressão de repercussões apontadas por eles quanto ao trabalho sobre a violência como uma inovação na gestão em saúde, muito além do mero significado de uma ação setorial. Além de demonstrar características avançadas do ponto de vista do conhecimento, tais exemplos também incorporam um forte conteúdo social e ideológico, o que não pode ser afirmado em relação a outros atores/gestores locais, a exemplo dos trabalhadores da saúde, com raras exceçōes, ou coordenadores do distrito sanitário, sem exceções.

- A identificação das inovações da gestão no DSBRV como redes transversais de informação em que se reconhece a existência de várias formas de especialidades: sociais, técnicas, econômicas e científicas (LÉVY 1999, p. 20), dentre as quais os Conselhos Locais de Saúde e o Fórum Comunitário de Combate à Violência, dada a sua atuação, podem ser categorizados como uma especialidade sóciotécnica ao lado de 
outras, como os grupos de trabalho dentro do próprio PACS. Seguindo os argumentos sugeridos por LÉVY (1999, p. 26), tais grupos locais podem, como especialidades sóciotécnicas ou sóciopolíticas, ser foco para a formação de coletivos inteligentes, se, no seu movimento, se constituirem em fonte de aprendizado recíproco.

Quero também destacar alguns pontos que reforçam as premissas assumidas no desenho téorico-metodológico do estudo de caso:

- A criação das inovações estudadas está relacionada com a existência de fontes e padrões anômalos do contexto local, principalmente por sua caracteristica processual, que é, ao mesmo tempo, um movimento de recusa à inércia.

- Existe uma capacidade de inovação de baixo para cima, que é também o reconhecimento de que existem recursos e capacidade de autogoverno e auto-aprendizagem dos atores/gestores locais, construídos através de relações singulares num tempo/espaço também singular. Isso fica muito claro na responsabilidade destacada na criação e identificação das inovações dos atores locais não-institucionais.

- O estudo de inovações na gestão em saúde a partir do cotidiano permite uma perspectiva heterogênea da realidade e, portanto, mais rica e ilimitada. Entender a inovação enquanto possibilidade sempre em movimento, e por isso transitória, ultrapassa sua compreensão como mero fenômeno, incapaz de gerar ou repercutir também nos espaços institucionais.

- A identificação de inovações na gestão, deve ser um processo de experimentação/exploração continuada e fundada nas suas trocas, o que implica também considerar que existirão efeitos positivos e negativos resultantes das inovações adotadas. 
No processo de interpretação e análise das inovaçōes também identifico alguns pontos débeis, que merecem ser destacados como um alerta, sobretudo aos atores/gestores locais.

Uma das qualidades observadas como insuficientes é justamente a governabilidade dos processos do agir público pelos atores locais. A própria articulação entre segmentos mais próximos, no que diz respeito à identidade de propósitos, como os Conselhos Locais de Saúde e outras organizações não-governamentais locais, é valorada como precária. Os modos e processos de articulação possuem características por demais transitórias e pontuais. Este parece ser um "mal" que pode ser qualificado como parte de um modo de ser brasileiro, que é a falta de memória. Isto significa que os processos desenvolvidos não acumulam produtos/resultados utilizáveis na condução da ação. Um dos caminhos para superar tal dificuldade é justamente valorizar os movimentos produzidos pelas pessoas comuns, de que, sem dúvida, as inovações identificadas servem como exemplos, ainda que limitados a uma realidade concreta.

Outro aspecto problemático é a insuficiente existência (e mesmo não existência) de fluxos de comunicação transversal por exemplo, entre conselheiros representantes da comunidade e conselheiros representantes dos trabalhadores da saúde ou mesmo entre membros do Fórum Comunitário de Combate à Violência, que têm uma atuação, em suas entidades de origem, direcionada para a luta da saúde. A importância disso é ressaltada na constatação de que sendo a gestão/organização da produção de açōes e serviços de saúde um produto da relação entre as pessoas, sem mudanças no processo de comunicação entre tais atores as inovações identificadas terão sempre um caráter restrito e uma capacidade limitada de contribuir para o processo de gestão em saúde. 
Tal situação é ainda mais grave se observarmos que a coordenação do DSBRV não dimensiona como prejuizo para a gestão da saúde o fato de que não tem, como órgão da administração pública, permitido a penetração, no seu interior, das redes transversais de informação criadas pelos diversos atores locais, principalmente via parcerias e alianças, mesmo que pontuais. Este processo sem dúvida fortaleceria a gestão da saúde mas, por ser caracterizado pela repartição de ação, responsabilidade e poder, não é considerado pelos atuais gestores institucionais da saúde.

Por fim, destaca-se uma particularidade nas inovações estudadas: todas se caracterizam como processo, o que dificulta seu reconhecimento e posterior disseminação e adoção. Ao não se caracterizar como uma técnica ou produto, as inovações não são facilmente perceptiveis para a maioria das pessoas que vivem e atuam no local, o que inclui os usuários dos serviços, cujo reconhecimento delas foi insuficiente. Ao mesmo tempo, considerando o contexto político-institucional desfavorável ao surgimento de inovações, estas têm conseguido um certo grau de disseminação, ainda que de modo insuficiente, dado que restrito fundamentalmente ao "espaço" saúde e quase restrito ao território do Distrito Sanitário Barra/Rio Vermelho.

Gostaria, para finalizar, de fazer algumas recomendações:

- Aos atores locais, que buscam na inovação também um modo de transformar a condução da saúde, recomendo que a atitude a ser assumida deve ser sempre de confronto com os defensores da manutenção do status quo em todas as áreas da vida: além da saúde, na economia, nas instituições e na vida cotidiana. Radicalizar o experimentalismo democrático é o modo como a resistência descobre seus próprios caminhos, mesmo em uma conjuntura local caracterizada por uma ordem autoritária e pela institucionalização de uma única "verdade". É também um modo de enfrentar e ultrapassar o próprio conflito moral e ético de mulheres e homens comuns, fortemente 
presente na realidade brasileira de hoje, e que consiste em lutar pela sobrevivência e contra a própria desesperança buscando uma compensação cada vez mais individual e menos coletiva.

- Aos dirigentes e técnicos das instituições públicas de saúde, que buscam exercer o seu dever de servidor público, um alerta: os recursos devem ser mais investidos nas pessoas, que são sempre capazes de criar soluçōes para problemas identificados, do que em produtos que aparentemente portam as soluções desejadas. No campo das inovações na gestão isso significa estimular a sua produção de baixo para cima e apoiar a sua disseminação no âmbito organizacional.

A perspectiva que o estudo de tais inovações cria pode ser objeto de interesse para futuras investigações. Assim, levanto algumas perguntas, a titulo de sugestão, para futuros investigadores do tema:

- Inovações com as características descritas são capazes de criar mudanças nos valores da organização pública responsável pela saúde?

- Quais repercussões podem causar na organização interna do governo do território do sistema local de saúde?

- Que produtos tais inovações podem ajudar a gerar?

- Como inovações com tais características podem fazer parte do conhecimento e da cultura da organização e ser apropriadas por outros atores locais?

- Em que medida inovações com as características daquelas identificadas podem contribuir para a reinvenção da administração pública da saúde? Tais inovações podem fazer parte do que se chama de gestão da mudança nas organizações? 
Procurando captar o caráter multidimensional e complexo que é estudar a gestão pública em saúde, principalmente em investigações microlocalizadas e com uma abordagem qualitativa, quero relembrar que todas as verdades são relativas, parciais e unilaterais (BAUMAN 1977, p. 164). Espero que, ao final do percurso e do conhecimento sistematizado no estudo de caso no Distrito Sanitário Barra/Rio Vermelho, cidade do Salvador, estado da Bahia, este contribua para que cada leitor tenha, afinal, reconhecido a sua verdade parcial. 


\section{REFERÊNCIAS}

Abrucio FL, Couto CG. A Redefinição do Papel do Estado no Âmbito Local. Fundação SEADE. São Paulo em Perspectiva. O Novo Município. Economia e Política. 1996; 3 (10): 40-47.

Abrucio FL, Costa VMF. Reforma do Estado e o Contexto Federativo Brasileiro. Stiftung: Konrad Adenauer; 1998: 12.

Acuña AE, Fernández FM. Análise de mudanças organizacionais: utilidades para politicas sociais. Rev Adm Públ 1995; 29 (2): 80-109.

Alencar EMLS de. Criatividade. $2^{a}$ ed. Brasilia (DF): Ed. Universidade de Brasília; 1995.

Almeida CM. Reforma sanitária brasileira: um trajeto de mudanças. Rio de Janeiro: FIOCRUZ/ENSP; 1993.

Almeida CM. As Reformas Sanitárias dos anos 80: crise ou transição? Rio de Janeiro; 1995, [Tese de Doutoramento, Escola Nacional de Saúde Pública/FIOCRUZ].

Almeida $M$, Feuerwerker $L$, Llanos $M$, (organizadores). Educação dos profissionais de saúde na América Latina. Teoria e prática de um movimento de mudança. São Paulo: Hucitec; Buenos Aires: Lugar Editorial; Londrina: Ed.UEL; 1999. 
Amadeo EJ. Em direção a um paradigma microdinâmico: a abordagem neoshumpetteriana. In: Amadeo EJ, organizador. Ensaios sobre a economia política moderna: teoria e história do pensamento econômico. São Paulo: Marco Zero; 1989. p. 157-185.

Andreazzi MFS e Tuna LFR, organizadores. Financiamento e Gestão do Setor Saúde: Novos Modelos. Rio de Janeiro: Ed. Escola Anna Nery; 1999.

Arretche M. O mito da descentralização como indutor de maior democratização e eficiência das políticas públicas. In: Gerschman S, Vianna MLW, coordenadoras. A Miragem da Pós-Modernidade. Democracia e políticas sociais no contexto da globalização. Rio de Janeiro: Fiocruz; 1997. p.127-52.

Bahia (Estado). Lei n. ${ }^{0}$ 7.027, de 29 de janeiro de 1997: Institui o Programa Estadual de Incentivo às Organizações Sociais e dá outras providências. Diário Oficial do Estado da Bahia, Salvador, 30 jan 1997, p.9-11.

Balandier G. A desordem. Elogio do movimento. Bertrand Brasil; 1997. Desordem na Modernidade; p. 155-261.

Bardin L. Análise de Conteúdo. Lisboa: Ediçōes 79; 1977.

Baremblitt G. Análise Institucional e Outras Correntes. Teoria e Prática. $3^{a}$ ed. Rio de Janeiro: Rosa dos Ventos; 1996.

Bauman Z. Por uma Sociologia Critica. Um ensaio sobre senso comum e emancipação. Rio de Janeiro: Zahar Editores; 1977.

Becker HS. Métodos de Pesquisa em Ciências Socias. $3^{\mathrm{a}}$ ed. São Paulo: HUCITEC; 1997. 
Benson D and Hughes JA. Method: evidence and inference - evidence and inference for ethnomethodology. In: Button G, editor. Ethnomethodology and the human sciences. Cambridge: Cambridge Univesity Press; 1991, pp. 109136.

Bloch RA e Balassiano M. A democratização da gestão pública: as relações entre gestor, inovação e porte demográfico do municipio. Rev Adm Púb 2000; 34 (1): 145-64.

Borgonovi E. Decentramento: un termine diversi contenuti. Azienda Pubblica 2000; $13(2 / 3)$ : 145-149.

Brasil. Ministério da Saúde. VIII Conferência Nacional de Saúde. Relatório Final. Brasilia, 1986.

Brasil. Ministério da Saúde. Norma Operacional Básica 1/93: dispõe sobre critérios para a descentralização de serviços de saúde. Diário Oficial da República Federativa do Brasil. Brasilia (DF), junho 1993.

Brasil. Presidência da República. Câmara da Reforma do Estado. Ministério da Administração Federal e Reforma do Estado. Plano Diretor da Reforma do Aparelho do Estado. Brasilia: MARE; 1995.

Brasil. Ministério da Saúde. Norma Operacional Básica 1/96: dispõe sobre critérios para a descentralização de serviços de saúde. Diário Oficial da República Federativa do Brasil. Brasília (DF), 7 de setem. 1996. 
Brasil. Ministério da Administração Federal e Reforma do Estado. Organizaçōes Sociais. Brasilia: MARE, Cadernos do MARE de Reforma do Estado 2; 1997.

Brasil. Ministério da Saúde. Secretaria de Politicas de Saúde. Departamento de Atenção Básica. Programa de Saúde da Familia e Agentes Comunitários de Saúde - Atividades 1999. Brasília; 2000.

Bresser-Pereira LC. A Reforma do Aparelho do Estado e a Constituição Brasileira. [Seminário sobre Reforma Constitucional realizado com os partidos políticos sob o patrocínio da Presidência da República; 1995 jan; Brasilia, Brasil].

Bresser-Pereira LC. Crise Econômica e Reforma do Estado no Brasil. Para uma nova interpretação da América Latina. São Paulo: Ed. 34; 1996.

Bresser-Pereira LC. A reforma gerencial do Estado de 1995. Rev Adm Púb 2000; 34 (4): 7-26.

Brown AD. Implementing information technology in the NHS: the role of narrative. Helath Services Management Research 1999; 12: 109-120.

Button G. Introduction: ethnomethodology and the foundational reespecification of the human sciences. In: Button $G$, editor. Ethnomethodology and the human sciences. Cambridge: Cambridge Univesity Press; 1991, pp. 1-9.

Campos AM. Em Busca de Novos Caminhos para a Teoria de Organização. Rev Adm Púb 1981; 15 (1): 104-123. 
Campos GWS. Reforma da reforma: repensando a saúde. São Paulo: Hucitec; 1992.

Campos GWS. Consideraçōes sobre a arte e a ciência da mudança: Revolução das coisas e reforma das pessoas. O caso da saúde. In: Cecilio LCO (organizador). Inventando a Mudança na saúde. São Paulo: HUCITEC, 1994, p.29-87.

Campos GWS. Um método para análise e co-gestão de coletivos. São Paulo: Hucitec, 2000.

Carvalho IMM de e Souza C. Reforma do Estado, Descentralização e Desigualdades. Lua Nova 1999; (48): 187-212.

Cecilio LC de O. Contribuiçōes para uma teoria da mudança. In: Cecilio LC de O, coordenador. Inventando a Mudança na Saúde. São Paulo: HUCITEC; 1994. p. 235-334.

Cecilio LC de O. A modernização gerencial dos hospitais públicos: o difícil exercicio da mudança. Rev Adm Púb 1997; 31 (3): 36-47.

Cecilio LC de O. O Estado como prestador direto da assistência hospitalar: sim ou não? Rev Adm Públ 33 (2): 23-37, 1999.

De Certeau M. A Invenção do Cotidiano. Artes do fazer. $3^{a}$ ed. São Paulo: Vozes; 1998.

Chanlat J-F. Modos de Gestão, Saúde e Segurança no Trabalho. In: Davel E, Vasconcelos J, coordenadores. Recursos Humanos e Subjetividade. Petrópolis/Rio de Janeiro: Vozes; 1995. p. 118-28. 
Christiansen PM. A Prescription Rejected: Market Solutions to Problems of Public Sector Governance. Governance. An International Journal of Policy and Administration 1998; 11(3): 273-295.

Cockerill R, Charles C and Roberts J. Adoption of a managerial innovation: a study of physician impact analysis. Health Services Management Centre; 1999; 12: 190-202.

Cohn A. Estado, Politicas Públicas e Saúde. In: Canesqui AM, organizadora. Ciências Sociais e Saúde. São Paulo: Hucitec/ABRASCO; 1997. p.157-71.

Cohn A. As Políticas Sociais no Governo FHC. Tempo Social, 1999; 11 (2): 183-197.

Cohn A e Elias PE, coordenadores. O Público e o Privado na saúde. O PAS em São Paulo. São Paulo: Editora Cortez; 1999.

Costa JBA da. A Ressignificação do Local: o imaginário político brasileiro pós80. Fundação SEADE. São Paulo em Perspectiva. O Novo Município. Economia e Política. 1996; (10): 3. p. 113-18.

Costa NR, Silva PLB e Ribeiro JM. A experiência internacional de reforma do setor saúde: inovações organizacionais e de financiamento. Rev Adm Públ 2000; 34 (1): 209-27.

Coulon A. L'Ethnométhodologie. 4ª ed. Paris: PUF; 1996.

Dawson S, Manderson L and Tallo VL. Social and Economic Research. The Focus Group Manual. Switzerland: World Health Organization; 1992. 
Diniz E. Governabilidade, democracia e reforma do Estado: os desafios da construção de uma nova ordem no Brasil dos anos 90. In: Diniz E e Azevedo S, organizadores. Reforma do Estado e democracia no Brasil. Brasilia: Editora Universidade de Brasilia, 1997.

Diniz E. Crise, governabilidade e Reforma do Estado: em busca de um novo paradigma. In: Gerschman S e Vianna MLW, organizadoras. A Miragem da Pós-Modernidade. Rio de Janeiro: FIOCRUZ, 1997a; p. 115-126.

Diniz E. Uma perspectiva analítica para a reforma do estado. Lua Nova 1998; (45): 29-48.

Dowbor L. Autonomia Local e Relações Internacionais. Rev Adm Mun 1991; 39 (203): 6-22.

Dowbor L. Governabilidade e descentralização. Revista do Serviço Público 1994; 118: 95-118.

Dupuis J-P. Antropologia, Cultura e Organização: Proposta de um Modelo Construtivista. In: Chanlat J-F, coordenador. $O$ Indivíduo na Organização. Dimensões Esquecidas. São Paulo: Atlas; 1996, V III. p. 231-51.

Farah MFS. Gestão pública e cidadania: iniciativas inovadoras na administração subnacional no Brasil. Rev Adm Púb 1997; 31 (4): 126-56.

Feyerabend P. Adeus à Razão. Lisboa: Edições 70; 1991.

Feyerabend P. Diálogo sobre o Método. Lisboa: Editorial Presença; 1991a. 
Feyerabend P. Contra o Método. Lisboa: Relógio D’ Água: 1993.

Fiorentini G. I servizi sanitari in Italia-2000. Milano: Società Editrice II Mulino; 2000.

Fórum Comunitário de Combate a Violência. Plano Operativo 1999-2000. Salvador; 1999. [Plano de ação elaborado pelo Fórum Comunitário de Combate a Violência de Salvador/BA]

Fundap. Novas Formas de Gestão dos Serviços Públicos. A Relação Público- Privado. São Paulo: Fundap; 1997.

Galard J. A Beleza do Gesto. São Paulo: EDUSP; 1997.

Gallo E. Razão, poder e política para repensar o planejamento. In: Gallo E, Rivera FJU, Machado, MH, coordenadores. Planejamento criativo. Novos desafios em políticas de saúde. Rio de Janeiro: Relume Dumará; 1992 .

Garfinkel $\mathrm{H}$ and Sacks H. On formal structures of pratical actions. In: Garfinkel $\mathrm{H}$, coordinator. Ethnomethodology Studies of Work. London: Routledge \& Kegan Paul; 1995. p.160-93.

Geertz C. A Interpretação das Culturas. Rio de Janeiro: Zahar Editores; 1995.

Gerschman S. A democracia inconclusa: um estudo da reforma sanitária brasileira. Rio de Janeiro: FIOCRUZ; 1995.

Gherardi S. Tradurre è tradire, ovvero la traslazione del controllo di gestione in ambito pubblico. II Nuovo Governo Locale 1998 2: 59-85. 
Giddens A. Novas Regras do Método Sociológico. $2^{a}$ ed. Lisboa: Gradiva; 1996.

Giddens A. Política, Sociologia e Teoria Social. São Paulo: Editora da UNESP; 1998. Garfinkel, Etnometodologia e Hermenêutica; p. 283-96.

Goodwin $C$ and Duranti $A$, editors. Rethinking context. Language as an interactive phenomenon. Cambridge: Cambridge University Press; 1997. Rethinking context: an introduction; p.1-42.

Gori C. Servizi Sociali e Mercato: La Riforma della Gran Bretagna. II Nuovo Governo Locale, 1998, 1: 103-23.

Governar a Saúde com a Frente Popular. Salvador; 1992. [Proposta elaborada pelo Comitê da área da saúde pró-candidatura Lídice da Mata à Prefeitura de Salvador, Bahia].

Guimarães MCL. Estado, Municipios e Processo Decisório: Estudo da Descentralização da Saúde no Estado da Bahia, 1993-1997. Salvador; 1997. [Projeto de Tese de Doutorado/Escola de Administração. Universidade Federal da Bahia].

Guimarães MCL. Descentralização da Saúde, Interesses e Conflitos Decisórios: 0 processo de decisão nas instâncias colegiais estaduais, Bahia, 1993-1997. Salvador; 2000. [Tese de Doutorado/Escola de Administração. Universidade Federal da Bahia].

Haguette TMF. Metodologias Qualitativas na Sociologia. Petrópolis: Vozes; 1987. 
Heller A. O Cotidiano e a História. $6{ }^{2}$ ed. São Paulo: Paz e Terra; 2000.

Heydebrand WV. Organization and Praxis. In: Morgan G, coordinator. Beyond Method. Strategies for Social Research. Beverly Hills: Sage Publications; 1983. p.306-20.

Jacobi P. Os Municípios e a Participação. Desafios e Alternativas. Rev Adm Púb 1991; 38 (198): 32-8.

Junqueira LP. A Descentralização e a Reforma do Aparato Estatal em Saúde. In: Canesqui AM, organizadora. Ciências Sociais e Saúde. São Paulo: HUCITEC/ABRASCO; 1997. p.173-204.

Kisil M, Chaves M, (organizadores). Programa UNI: Uma nova iniciativa na educação dos profissionais de saúde. Battle Creek: Fundação Kellogg; 1994.

Kliksberg B. A Gerência na Década de 90. Rev Adm Púb 1988; 22(1): 59-85.

Kliksberg B. A Gerência do Final do Século XX. Rev Adm Púb 1993; 27(2): 183-201.

Kliksberg B. A modernização do estado para o desenvolvimento social algumas questões-chave. Rev Adm Púb 1996; 30(1): 78-90.

Kliksberg B. O Desafio da Exclusão. Para uma Gestão Social Eficiente. São Paulo: FUNDAP; 1997. O Redesenho do Estado para O Desenvolvimento Socioêconomico e a Mudança: uma Agenda Estratégica para a Discussão. p. 49-73 e Uma Agenda Pública para os Novos Tempos. p. 75-97. 
Kliksberg B. Seis teses não-convencionais sobre participação. Rev Adm Púb $1999 ; 33(3): 7-37$.

Krippendorff K. Content Analysis. An Introduction to its Methodology. $5^{\text {th }} \mathrm{ed}$. Beverly Hills: Sage Publications; 1985.

Krueger RA. Focus Group. A Practical Guide for Applied Research. $2^{\text {nd }}$ ed. Thousand Oaks: Sage Publications; 1994.

Lapassade G. Les Microsociologies. Paris: Ed. Economica; 1996.

Leite DBC e col. Inovação na Universidade: a pesquisa em parceria. Interface. Comunicação, Saúde e Educação 1999; 4 (3): 41-52.

Lévy P. A inteligência coletiva. Por uma antropologia do cyberespaço. $2^{2}$ ed. São Paulo: Edições Loyola; 1999.

Livingston E. Make Sense of Ethnomethodology. London/New York: Routledge \& Kegan Paul; 1987.

Malik AM, Vecina Neto G. Desenhando um caminho alternativo para a gerência de serviços de saúde.[Trabalho apresentado no Seminário "Novas Concepções em Administração e Desafios do Sistema Único de Saúde. Em Busca de Estratégias para o desenvolvimento gerencial". Escola Nacional de Saúde Pública e FUNDAP; 1990, out. 15-19; Rio de Janeiro, Brasil].

Martins JS. O senso comum e a vida cotidiana. Tempo Social. Rev Sociol USP 1998; 10(1): 1-8.

Matus C. Política, Planejamento e Governo. Brasilia (DF): IPEA; 1993. 
Melo C, Cabrera G, Carneiro MC, Cherchiglia ML, Domingues MA, Maeda S. As Organizações Sociais como executoras de açōes públicas não estatais de saúde. São Paulo; 1998 [Série Monográfica n.11 do Departamento de Prática de Saúde Pública/Faculdade de Saúde Pública/USP].

Mendes EV, organizador. Distritos Sanitários: o processo social de mudanças das práticas sanitárias no Sistema Único de Saúde. Rio de Janeiro/São Paulo: Hucitec/ABRASCO; 1993.

Mendes VLPS. Inovação Gerencial na Administração Pública. Um Estudo na Esfera Municipal no Brasil. Salvador; 2001. [Tese de Doutorado/Escola de Administração. Universidade Federal da Bahia].

Merhy EE. A luta na saúde pela defesa da vida e algumas questões sobre o sujeito formulador: contribuições para o planejamento e gestão dos serviços. São Paulo: CEFOR; 1997a. p.1-6.

Merhy EE. O SUS e um dos seus dilemas: mudar a gestão e a lógica do processo de trabalho em saúde (um ensaio sobre a micropolitica do trabalho vivo). In: Fleury, S., coordenadora. Saúde e Democracia - A Luta do CEBES. São Paulo: Lemos Editorial; 1997b. p.125-141.

Merhy EE et al. Em busca de ferramentas analisadoras das tecnologias em saúde: a informação e o dia a dia de um serviço interrogando e gerindo trabalho em saúde. In: Merhy EE e ONOCKO R., coordenadora. Agir em saúde. Um desafio para o público. São Paulo: Hucitec; 1997c. p.113-150. 
Merhy EE . Em busca do tempo perdido: a micropolítica do trabalho vivo em saúde. In: Merhy EE e Onocko R, coordenadores. Agir em saúde. Um desafio para o público. São Paulo: Hucitec; 1997d. p. 71-112.

Merhy EE. $O$ ato de governar as tensões constitutivas do agir em saúde como desafio permanente de algumas estratégias gerenciais. Ciência e Saúde Coletiva $1999 ; 4(2)$ : 305-314.

Merhy EE. Reflexões sobre as tecnologias não materiais em saúde e a reestruturação produtiva do setor: um estudo sobre a micropolítica do trabalho vivo. Campinas; 2000. TTese de Livre-Docência _ Faculdade de Ciências Médicas da Universidade de Campinas].

Minayo MC de S. O Desafio do Conhecimento. São Paulo: HUCITEC/ABRASCO; 1993.

Ministério Público Federal. Procuradoria Federal dos Direitos do Cidadão. Parecer jurídico anexado ao processo n. 08100.002351/98-15, visando ações diretas de inconstitucionalidade contra leis estaduais e Lei Federal 9.637, de 15/5/98. Brasília (DF); 1998.

Modesto P. Reforma administrativa e marco legal das organizações sociais no Brasil: As dúvidas dos juristas sobre o modelo das organizações sociais. Trabalho apresentado ao II Congresso Interamericano sobre a Reforma do Estado e da Administração Pública]. Centro Latino Americano para el Desarrollo; 1996, outubro; llha Margarita, Venezuela.

Morgan G. Imaginization. The art of creative management. Newbury Park: Sage Publications; 1993. 
Mcrin E. O Método. As Idéias. Habitat, vida, costumes, organização. Porto Alegre: Sulina; 1998.

Morse JM. Designing Funded Qualitative Research. In: Denzin NK, Lincoln YS, coordinators. Handbook of Qualitative Research. Thousand Oaks: Saqe Publications;1994. p. 221-35.

Motta PR. Gestão Contemporânea: a ciência e a arte de ser dirigente. $3^{\mathrm{a}}$ ed. Rio de Janeiro: Record; 1993.

Mucchielli A, directeur. Dictionnaire des méthodes qualitatives en sciences humaines et sociales. Armand Colin: Paris; 1995.

Oliveira F. A Derrota da Vitória. A contradição do absolutismo de FHC. Novos Estudos CEBRAP 1998; 50: 13-21.

Paim JS. Sistema Unificado e Descentralizado de Saúde - SUDS/BA. A Reforma Sanitária. Revista Baiana de Saúde Pública 1987; 14 (2/4): 232-243.

Paim JS. Obstáculos não superados na implantação do SUDS-BA. Saúde em Debate 1990; 28: 16-21.

Paim JS, Silva LMV, Costa MCN, Lessa I e Almeida LM. Análise da situação de saúde do município de Salvador segundo condições de vida, 19911994. Salvador, 1997. [Relatório técnico do projeto integrado de pesquisa]

Patton MQ. Qualitative Evaluation and Researchs Methods. $2^{\text {nd }}$ ed. Newbury Park: Sage Publications; 1990. 
Peile C. The Creative Paradigm. Newcastle upon Tyne: Avebury Series in Philosophy; 1994.

Peretz H. Les méthodes en sociologie. L' observation. Paris: La Découveret; 1998.

Perleth $\mathrm{M}$, Jakubowski $\mathrm{E}$ and Busse $\mathrm{R}$. What is best practice in health care? State of the art and perspectives in improving the effectiveness and efficiency of the European health care systems. Health Policy 2001; 56: 235-250.

Pinho JAG, Santana MW e Cerqueira SMB. Gestão Pública em Busca de Cidadania: Experiências de Inovação em Salvador. Organizações \& Sociedade 1997; 4 (8): 57-90.

Pinho JAG e Santana MW. Inovação na gestão pública no Brasil: Uma aproximação teórico-conceitual. In: ENANPAD, 22. Anais. Foz do Iguaçú, ANPAD; 1998. p. 1-16.

Pinto RF. Inovações no fornecimento de bens e serviços públicos. Rev Adm Públ 1999; 33 (11): 135-49.

Pollitt C. Is the emperor in his underwear? An analysis of the impacts of public management reform. Rotterdam: Routledge, 2000.

Projeto UNI/BA. Avaliação UNI 1998. Grupo Focal com Conselheiros da Comunidade. Salvador, 1999. [Documento-síntese da avaliação realizada com conselheiros de saúde representantes da comunidade] 
Qualitative Solutions and Research Pty Ltd. QSR NUD.IST 4. [Software for Qualitative Data Analysis]. Second Edition. Australia: SCOLARI/ Sage Publications Software; 1997.

Quarto Congresso exige mais saúde na Bahia. Jornal do SINDSAÚDE, Salvador, 1999; setembro, n.55, p.1-3.

Robinson JC. Organizational Economics and a Health Care Markets. In: Bernstein $A B$ and Gauthier AK, editors. Data Needs for Studies of Competition in Markets Areas. Health Services Research 2001; 36 (Suppl 1): 10-32.

Salvador (Município). Decreto-Lei n. 11.469, de 11 de novembro de 1996: Aprova o regimento de Conselhos Locais de saúde da Secretaria Municipal de Saúde/SMS, e dá outras providências. Diário Oficial do Município do Salvador, Salvador, nov 1997, p. 3-5.

Santos M. A Natureza do Espaço. Técnica e Tempo. Razão e Emoção. São Paulo: HUCITEC; 1996. O Lugar e o Cotidiano; p. 251-65.

São Paulo (Estado). Projeto de Lei Complementar n. ${ }^{\circ} 3$, de 1998. Dispõe sobre a qualificação de entidades como organizações sociais e dá outras providências. Diário Oficial do Estado de São Paulo. São Paulo, 19 de fevereiro de 1998, p.45.

Saraiva LAS e Capelão LGF. A nova administração pública e o foco no cidadão: burocracia x marketing? Rev Adm Públ 2000; 34(2): 59-77.

De Sardan J-P. Anthropologie et Dévelopment. Essai en socioanthropologie du changement social. Paris: APAD-Karthaela; 1995. 
Sartori G. A política. Lógica e Método nas Ciências Sociais. $2^{\mathrm{a}}$ ed. Brasilia: Ed.UNB; 1997.

Schraiber LB, Peduzzi M, Sala A, Nemes MIB, Castanhera ERL e Kon R. Planejamento, gestão e avaliação em saúde: identificando problemas. Ciências \& Saúde Coletiva 1999; 4 (2): 221-242.

Secretaria da Saúde do Estado da Bahia. Proposta de distritalização para o Estado da Bahia. Salvador; 1988.[Documento de trabalho da SESAB elaborado pelo Grupo de Apoio à Distritalização]

Secretaria Municipal da Saúde de Salvador. Proposta de descentralização da saúde para a cidade do Salvador. Salvador; 1994.

Secretaria Municipal da Saúde de Salvador. Descentralização da Gestão das Ações e Serviços de Saúde no Município de Salvador (Bahia). Salvador; 1997.

Secretaria Municipal da Saúde de Salvador. Plano Municipal de Saúde 19982001. Salvador; $1997 a$.

Secretaria Municipal da Saúde de Salvador. Relatório de Gestão. Salvador; 1999.

Secretaria Municipal da Saúde de São Paulo. Plano de Atenção a Saúde PAS. Resumo executivo. São Paulo, SMS, 1996.

Secretaria Municipal da Saúde de São Paulo. Plano de Atenção a Saúde PAS- PAS: projeto básico. Versão 2, São Paulo sd. 
Sousa Santos B. A Reinvenção Solidária e Participativa do Estado. [Apresentado ao Seminário Internacional Sociedade e a Reforma do Estado, promovido pelo MARE, s/d. Brasil]

Souza C. Reinventando o Poder Local: limites e possibilidades do federalismo e da descentralização. Fundação SEADE - São Paulo em Perspectiva. O Novo Município. Economia e Politica 1996; (10) 3:103-12.

Souza C e Carvalho IMM. Reforma do Estado, Descentralização e Desigualdades. Lua Nova 1999; 48: 187-212.

Spink MJ, organizadora. Práticas Discursivas e Produção de Sentidos no Cotidiano. Aproximações teóricas e metodológicas. São Paulo: CORTEZ; 1999.

Tanaka OY e Melo C. Inovação e Gestão: Análise da Gestão Cotidiana de uma Organização Social de Saúde. São Paulo; 2000.[Relatório Final de Pesquisa apresentado à FAPESP].

Tanaka OY. Palestra proferida na Pré-Conferência da Faculdade de Saúde Pública para a $11^{\mathrm{a}}$ Conferência Nacional de Saúde. São Paulo, 7 de novembro de 2000.

Teixeira SMF. O dilema da Reforma Sanitária Brasileira. In: Berlinguer G. e col., coordenadores. Reforma Sanitária: Itália e Brasil. São Paulo: HUCITECIABRASCO; 1988. p. 195-207.

Teixeira SMF. Reforma Sanitária: em busca de uma teoria. São Paulo/Rio de Janeiro: CORTEZ/ABRASCO; 1989. 
Teixeira SMF. Descentralização dos serviços de saúde: dimensões analíticas. Rev Adm Públ 1990; 24 (2): 78-99.

Teixeira SMF. Descentralização dos serviços de saúde: dimensões analíticas. Cadernos da Nona 1992; 1: 27-37.

Teixeira SMF. Programa de Estudos e Pesquisas em Reforma do Estado e Governança. Rev Adm Públ 1997; 31 (5): 195-204.

Tenório FG. Programa de Estudos em Gestão Social. Rev Adm Públ 1999; 33 (6): 229-38.

Testa M. Pensamento Estratégico e Lógica de Programação. O caso da saúde. São Paulo/Rio de Janeiro: Hucitec/ABRASCO; 1995.

Testa M. Análisis de Instituciones Hipercomplejas. In: Merhy EE e ONOCKO R, coordenadora. Agir em saúde. Um desafio para o público. São Paulo: HUCITEC; 1997. p.17-70.

Tomassini M e Bonaretti M. Le comunità di pratica nei processi di innovazione della pubblica amministrazione. In: Battistelli (a cura di). La pubblica amministrazione tra riforma e mutuamento culturale. Milano: Angeli; 2001.

Ugá MA. Descentralização e Democracia: O Outro Lado da Moeda. Planej Pol Púb 1991; 5. 
Ugá MA. Ajuste Estrutural, Governabilidade e Democracia. In: In: Gerschman SE, Vianna MLW, coordenadoras. A Miragem da Pós-Modernidade. Democracia e politicas sociais no contexto da globalização. Rio de Janeiro: Fiocruz; 1997. p. 81-99.

Uribe Rivera FJ, organizador. Planejamento e Programação em Saúde. Um enfoque estratégico. São Paulo: Cortez/ABRASCO; 1989.

Uribe Rivera FJ. Agir Comunicativo e Planejamento Social: Uma Crítica ao Enfoque Estratégico. Rio de Janeiro: Fiocruz; 1995.

Viana AL. As políticas sociais e as políticas de saúde no contexto do processo de globalização. In: Gerschman SE, Vianna MLW, coordenadoras. A Miragem da Pós-Modernidade. Democracia e políticas sociais no contexto da globalização. Rio de Janeiro: Fiocruz; 1997. p.201-209.

Vilasbôas ALQ. Vigilância à Saúde e Distritalização: A Experiência de Pau da Lima. Salvador; 1998, [Dissertação de Mestrado, Instituto de Saúde Coletiva da Universidade Federal da Bahia].

Yin RK. Case Study Research. Design and Methods. Second ed. Thousand Oaks: SAGE; 1994. 


\section{ANEXOS}




\section{ANEXO 1}

\section{Guia de perguntas para entrevista}

\section{ENTREVISTA EXPLORATÓRIA}

Entrevistado:

Data:

Local:

Entrevistador:

OBJETIVOS:

- mapear possiveis inovações

- identificar acontecimentos

- identificar práticas alternativas da gestão (gestão autônoma da saúde)

\section{ROTEIRO:}

1. identifica alguma irrupção/ fenômeno não rotinizado/irregular/fora do comum no distrito sanitário barra/rio vermelho? e em relação à gestão?

2. defina inovação.

3. quais as caracteristicas da gestão em saúde no DSBRV?

4. quem gere a saúde neste local?

5. quais as formas de governar os processos de trabalho e forma de governar a atenção à saúde da população?

6. o que pode significar hoje uma perspectiva de futuro na gestão em saúde no espaço do DSBRV? 
ENTREVISTADO:

DATA:

ENTREVISTADOR:

OBJETIVOS:

- mapear inovações ou pistas para inovações

- caracterizar inovações

- definir inovação

ROTEIRO:

1. descreva o seu trabalho rotineiro.

2. quais os aspectos positivos no seu trabalho?

3. quais as barreiras identificadas no trabalho?

4. quais as características da gestão em saúde no dsbrv?

5. você identifica alguma inovação na gestão da saúde no dsbrv? descreva suas características.

6. defina inovação.

7. observaçōes após a entrevista 
Data:

Membros:

Observador:

Local:

\section{USUÁRIOS}

1. Qual o serviço público de saúde que você mais usa?

2. O que você gosta mais nele?

3. O que você gosta menos?

4. É fácil ser atendido?

5. O que você faz para ser atendido?

6. Para você existe alguma coisa nova nos serviços que freqüenta?

7. O que fazer para melhorar?

\section{CONSELHEIROS:}

Descreva seu cotidiano como Conselheiro

Quem gere a saúde no Distrito?

Você identifica algo diferente no Distrito? O quê?

Defina inovação 


\section{ANEXO 3}

Roteiro para anotação do grupo focal

GUIA PARA OBSERVAÇÃO DO GRUPO FOCAL

GRUPO:

DATA:

LOCAL:

OBSERVADORA:

DURAÇÀO:

\begin{tabular}{|l|l|l|l|l|l|}
\hline TEMA & CRENÇAS & ATITUDES & OPINIŌES & $\begin{array}{c}\text { SINAIS NĀO } \\
\text { VERBAIS } \\
\text { SIGNIFICANTES }\end{array}$ & $\begin{array}{c}\text { EXPRESSŌES } \\
\text { FACIAIS E } \\
\text { CORPORAIS }\end{array}$ \\
\hline & & & & & \\
& & & & & \\
\hline
\end{tabular}

OBSERVAÇÕES: 


\section{ANEXO 4}

\section{Matrizes preliminares para análise dos achados}

MATRIZ 1. ELEMENTOS E PLANOS POTENCIAIS PARA ANÁLISE QUALITATIVA

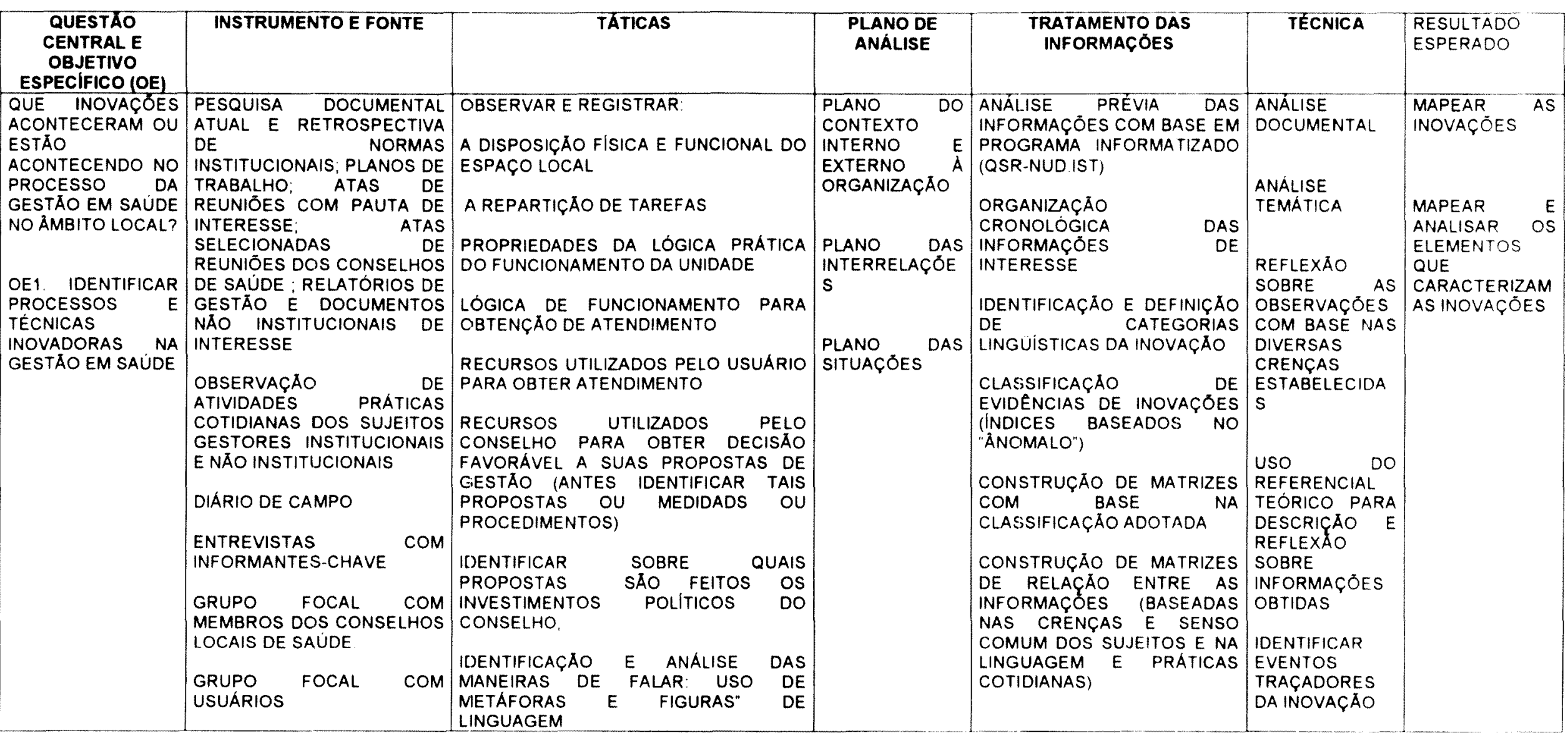




\section{ANEXO 5}

\section{Lista preliminar de nós produzidos no Q.S.R. NUD.IST}

Q.S.R. NUD.IST Power version, revision 4.0.

(1) Plano de análise do contexto interno e externo

(1 1) Plano de análise do contexto interno e extemo/Cotidiano

(1 11 1) Plano de análise do contexto interno e externo/Cotidiano/Problemas(l 112 )

Plano de análise do contexto intemo e extemo/Cotidiano/Táticas(1 13) Plano de

análise do contexto intemo e externo/Cotidiano/Enunciação avaliativa

(1 1 4) Plano de análise do contexto interno e externo/Cotidiano/Perspectivas

(12) Plano de análise do contexto interno e externo/Politica local

(1 2 1) Plano de análise do contexto interno e externo/Politica local/Govemo municipal

(1 2 2) Plano de análise do contexto interno e externo/Politica local/Municipalização

(1 2 3) Plano de análise do contexto interno e externo/Politica local/Conselho

Municipal de Saúde

(1 2 4) Plano de análise do contexto interno e externo/Politica local/SMS

(1 2 5) Plano de análise do contexto interno e extemo/Politica local/DSBRV

(1 2 6) Plano de análise do contexto interno e externo/Politica local/Universidade

(1 2 2 7) Plano de análise do contexto interno e externo/Política local/Midia

(1 2 8) Plano de análise do contexto interno e externo/Politica local/Perspectivas

(1 2 9) Plano de análise do contexto interno e externo/Politica local/Politica

(1 3) Plano de análise do contexto interno e extemo/Gestão do DSBRV

(1 3 1) Plano de análise do contexto interno e externo/Gestão do DSBRV/Modelo de gestão

(1 31 1) Plano de análise do contexto intemo e externo/Gestão do DSBRV/Modelo de gestão/Acesso

(1 31 2) Plano de análise do contexto intemo e externo/Gestão do DSBRV/Modelo de gestão/Acesso/Informação

(1 313 ) Plano de análise do contexto intemo e externo/Gestão do DSBRV/Modelo de gestão/Serviços de Saúde

(1 314 ) Plano de análise do contexto intemo e externo/Gestão do DSBRV/Modelo de gestão/Decisão, participação e acesso

(1 3 2) Plano de análise do contexto intemo e extemo/Gestão do DSBRV/Perfil do

gestor(1 33 3) Plano de análise do contexto intemo e externo/Gestão do

DSBRV/Gestor/ldentificação(1 34 4) Plano de análise do contexto interno e

extemo/Gestão do DSBRV/Enunciação avaliativa

(1 3 5) Plano de análise do contexto interno e extemo/Gestão do DSBRV/Perspectivas 
(2) Plano de análise das relações

(2 1) Plano de análise das relaçõesíRelações

(2 1 1) Plano de análise das relações/Relações/Gerentes $\times$ Trabalhadores

(2 1 2) Plano de análise das relações/Relações/Gerentes $x$ Conselheiros

(2 13) Plano de análise das relaçōes/Relaçōes/Gerentes $\times$ Coordenação do DS

(2 14) Plano de análise das relações/Relações/Gerentes $\times$ Associação do Bairro

(2 15 ) Plano de análise das relações/Relações/Conselheiros $\times$ Conselheiros

(2 16 ) Plano de análise das relações/Relações/Conselheiros $x$ Trabalhadores

(2 17 ) Plano de análise das relações/Relações/Conselheiros $\times$ SMS

(2 18 ) Plano de análise das relações/Relações/Conselheiros $x$ Coordenação do DS

(2 1 9) Plano de análise das relações/Relações/Trabalhadores $x$ Trabalhadores

(2 1 10) Plano de análise das relações/Relações/Trabalhadores $x$ Usuários

(2 1111 ) Plano de análise das relações/Relações/Coordenação DS x SMS

(2 1 12) Plano de análise das relações/Relações/Coordenação do DS x Universidade

(2 2) Plano de análise das relações/Enunciação Avaliativa

(2 2 1) Plano de análise das relações/Enunciação Avaliativa/Território(2 21 1) Plano

de análise das relações/Enunciação Avaliativa/Território/Liderança comunitária

(2 21 2) Plano de análise das relações/Enunciação Avaliativa/Território/Associação do bairro

(2 2 1 3) Plano de análise das relações/Enunciação Avaliativa/Território/Moradores

(2 2 2) Plano de análise das relações/Enunciação Avaliativa/Academia(2 22 1) Plano

de análise das relações/Enunciação Avaliativa/Academia/Universidade(2 22 2) Plano de análise das relaçōes/Enunciação Avaliativa/Academia/Professores

(2 2 3) /Plano de análise das relações/Enunciação Avaliativa/Instituições locais de saúde

(2 23 1) Plano de análise das relações/Enunciação Avaliativa/Instituições locais de saúde/SMS

(2 23 2) Plano de análise das relações/Enunciação Avaliativa/Instituiçōes locais de saúde/Coordenação do DSBRV

(2 23 3) Plano de análise das relações/Enunciação Avaliativa/Instituições locais de saúde/Gerentes

(2 23 4) Plano de análise das relações/Enunciação Avaliativa/Instituições locais de saúde/Trabalhadores da Saúde

(2 23 5) Plano de análise das relações/Enunciação Avaliativa/Instituições locais de saúde/Serviços de Saúde 
(3 1) Plano de análise das situações/Inovação

(3 11 1) Plano de análise das situações/Inovação/Definição(3 12 2) Plano de análise das situações/Inovação/Exemplos

(3 $\left.1 \begin{array}{lll} & 2 & 1\end{array}\right)$ Plano de análise das situações/Inovação/Exemplos/CLS

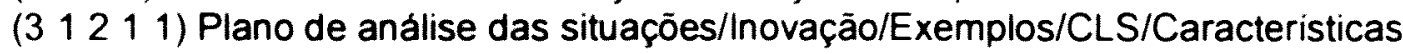

(3 $\left.1 \begin{array}{lll} & 2 & 1\end{array}\right)$ 2) Plano de análise das situações/Inovação/Exemplos/CLS/Concepção sobre o papel

(3 $\left.12 \begin{array}{lll}3 & 1 & 3\end{array}\right)$ Plano de análise das situações/Inovação/Exemplos/CLS/Perfil conselheiros

(3 12214 ) Plano de análise das situações/Inovação/Exemplos/CLS/Ação e táticas

(3 12214 1) Plano de análise das situações/Inovação/Exemplos/CLS/Ação e táticas/Barreiras

(3 1214 2) Plano de análise das situações/Inovação/Exemplos/CLS/Ação e táticas/Facilitadores

(3 121 5) Plano de análise das situações/Inovação/Exemplos/CLS/Enunciação avaliativa

(3 12 1 16 ) Plano de análise das situações/Inovação/Exemplos/CLS/Repercussões

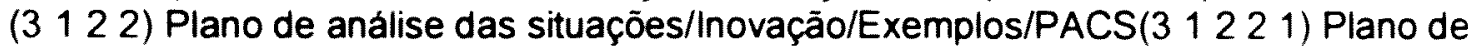
análise das situações/Inovação/Exemplos/PACS/Caracteristicas locais(3 1222 2)

Plano de análise das situações/Inovação/Exemplos/PACS/Trabalho ACS

(3 1222 3) Plano de análise das situaçōes/Inovação/Exemplos/PACS/Significado e uso estratégico

(3 12 2 2 4) Plano de análise das situações/Inovação/Exemplos/PACS/Enunciação avaliativa

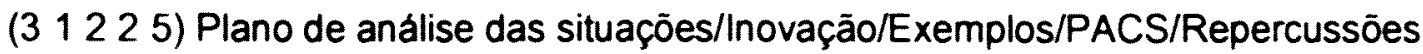

(3 12 2 3 ) Plano de análise das situaçōes/Inovação/Exemplos/Projeto UNI(3 1223 1)

Plano de análise das situações/Inovação/Exemplos/Projeto UNI/Caracteristicas(3 123

2) Plano de análise das situaçōes/Inovação/Exemplos/Projeto UNI/Influência

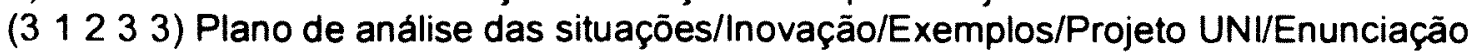
avaliativa

(3 1223 4) Plano de análise das situações/Inovação/Exemplos/Projeto UNI/Repercussões

(3 12 4) Plano de análise das situações/Inovação/Exemplos/Trabalhando com a violência

(3 1224 1) Plano de análise das situações/Inovação/Exemplos/Trabalhando com a violência/Niolência: um problema de saúde

(3 12 2 4 2) Plano de análise das situações/Inovação/Exemplos/Trabalhando com a violência/Fórum Comunitário de Combate à Violência

(3 1224 3) Plano de análise das situações/Inovação/Exemplos/Trabalhando com a violência/Enunciação avaliativa

(3 1224 4) Plano de análise das situaçōes/Inovação/Exemplos/Trabalhando com a violência/Repercussões

(3 12244 1) Plano de análise das situações/Inovação/Exemplos/Trabalhando com a violência/Repercussões/Nas pessoas

(3 12444 2) Plano de análise das situações/Inovação/Exemplos/Trabalhando com a violência/Repercussões/Entre as pessoas

(3 122444 ) Plano de análise das situaçōes/Inovação/Exemplos/Trabalhando com a violência/Repercussões/ $\mathrm{Na}$ maneira de ver a realidade 